


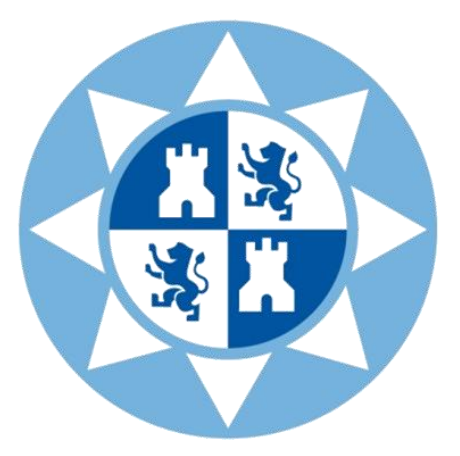

Universidad Politécnica de Cartagena

Departamento de Producción Vegetal

\section{Estrategias con riego automático para controlar la salinidad en plantas ornamentales en maceta}

\section{Raquel Valdés Illán}

2014 


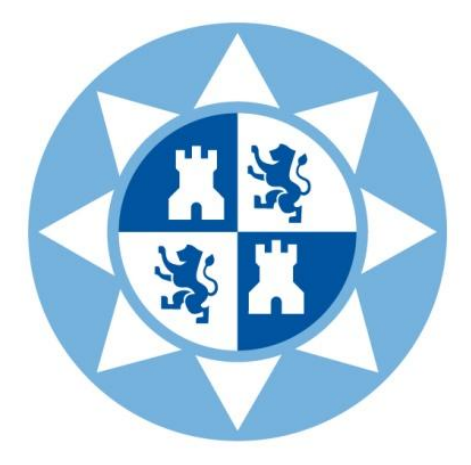

Universidad Politécnica de Cartagena Departamento de Producción Vegetal

\title{
Estrategias con riego automático para controlar la salinidad en plantas ornamentales en maceta
}

\author{
Raquel Valdés Illán
}

\author{
Directores:
}

Sebastián del Pilar Bañón Arias

María Jesús Sánchez Blanco 


\section{RECONOCIMIENTOS}

Este trabajo se encuadra dentro de las actividades del Departamento de Producción Vegetal de la Universidad Politécnica de Cartagena en los proyectos de investigación CICYT "Influencia del manejo del riego con aguas marginales sobre el desarrollo de plantas ornamentales y el medio de cultivo: desarrollo en maceta y en el paisaje urbano" (AGL2011-30022-C02-01 y 02) y “Técnicas de cultivo en arbustos mediterráneos para reducir los efectos negativos del riego con aguas de baja calidad" (AGL2008-05258-CO21 y 2$)$.

Los resultados de la presente tesis doctoral han sido publicados en:

\section{Revistas científicas:}

- Valdés, R., Miralles, J., Ochoa, J., Sánchez-Blanco, M. J., Bañón, B., 2012. Saline reclaimed wastewater can be used to produce potted weeping fig (Ficus benjamina L.) with minimal effects on plant quality. Spanish Journal of Agricultural Research, 10, 1167-1175.

- Valdés, R., Miralles, J., Franco, J.A., Sánchez-Blanco, M. J., Bañón, B., 2014. Using soil bulk electrical conductivity to manage saline irrigation in the production of potted poinsettia. Scientia Horticulturae 170, 1-7.

- Valdés, R., Miralles, J., Ochoa, J., Sánchez-Blanco, M. J., Bañón, B., 2014. The number of emitters alters salt distribution and root growth in potted gerbera. HortScience 49, 160-165.

- Valdés, R., Ochoa, J., Franco, J.A., Sánchez-Blanco, M. J., Bañón, B., 2015. Saline irrigation scheduling for potted geranium based on soil electrical conductivity and moisture sensors. Agricultural Water Management 149, 123-130.

\section{Congresos:}

- Miralles, J., Valdés, R., Franco, J.A., Sánchez-Blanco, M. J., Bañón, B., 2012. Manejo del riego con agua residual salina para la producción de Ficus benjamina: consumo de agua y desarrollo. XIII Congreso Nacional de Ciencias Hortícolas. 1620 de abril de 2012, Almería. Actas de Horticultura 60, 550-553.

- Valdés, R., Ochoa, J., Franco, J.A., Sánchez-Blanco, M.J., Bañón, S., 2013. El número de goteros por maceta afecta a la distribución de raíces y sales en el 
sustrato en gerbera. VII Congreso Ibérico de AgroIngeniería y Ciencias Hortícolas. Madrid, 26- 29 Agosto 2013.

- Valdés, R., Alcaraz, M.S., Franco, J.A., Sánchez-Blanco, M. J., S. Bañón, S., 2014. Programación del riego de geranio con agua salina utilizando sensores de conductividad eléctrica y humedad del suelo. I Symposium nacional de ingeniería hortícola "La Agromótica en la Horticultura" Orihuela 20-22 febrero 2014. Actas de horticultura 64.

- Valdés, R., Ochoa, J., Sánchez-Blanco, M. J., Álvarez, S., Bañón, B., 2014.Influencia del riego salino sobre el crecimiento y el contenido foliar de iones en un cultivo de Osteospermum en maceta. VI Jornadas Ibéricas Horticultura Ornamental. Valencia, octubre 2014.

- Valdés, R., Ochoa, J., Sánchez-Blanco, M. J., Miralles, J., Bañón, B., 2014. Relaciones entre conductividades eléctricas durante un cultivo en maceta de Osteospermum. Presentación Oral en VI Jornadas Ibéricas Horticultura Ornamental. Valencia, octubre 2014. 


\section{AGRADECIMIENTOS}

En primer lugar quiero dar las gracias a mi director de tesis, Sebastian del Pilar Bañón Arias, por confiar en mí desde que terminé Ingeniería Técnica Agrícola y brindarme esta gran oportunidad, la cual ha sido clave para mi formación. Han sido muchos años trabajando juntos y tratándome siempre con paciencia, cercanía, respeto y generosidad. Igualmente deseo expresar mi agradecimiento a mi codirectora María Jesús Sánchez Blanco, por ayudarme en todo lo que he necesitado y por ser una maravillosa compañera de congresos.

Agradecer a todos los que me han ayudado en la puesta en marcha de los ensayos y las mediciones, en especial mi compañero Julián Miralles, que gracias a él he aprendido muchas cosas que quedan reflejadas en esta tesis. También he tenido el placer de contar con la gran ayuda de Yolanda, Marisol, Paula y Ely, sin ellas no hubiera sido posible realizar todas las medidas y me gustaría destacar la alegría que trasmiten de cada una de ellas. Y como no nombrar a mis compañeros, ahora también amigos, Diana, Mayra, Adriana, Almudena, Carolina, Gonzalo y Manolo, ellos me han aportado sus conocimientos y consejos. Y por supuesto agradecer la ayuda recibida por parte del personal de la Finca Tomás Ferro, Francisco, José Anastasio, Pedro, Isa y Fini.

Agradecer a todos los profesores del Departamento de Producción Vegetal que siempre han estado dispuestos a ofrecerme su ayuda y en especial a Jesús Ochoa, por su ayuda en campo y en todo lo que he necesitado; Encarna Conesa y Juan Antonio Martínez, por su ayuda en el laboratorio; y a Pablo Bielza, por sus comentarios sobre estadística cuando nos surgían dudas.

Agradecer a mis padres y hermanos, por el hecho de estar siempre ahí, confiar en mí, cuidarme, motivarme y por su apoyo incondicional y a mis sobrinas por ser la alegría de la familia. A mis amigas Aida, Choni, Tamara, Vero y Marina, por saber escuchar y por el apoyo recibido durante muchos años. Por último destacar mi agradecimiento a Jose María por todo el apoyo recibido, el ánimo y motivación que me ha aportado en los momentos más duros de esta tesis y especialmente por compartir el día a día conmigo. 
ABSTRACT/RESUMEN 


\section{ABSTRACT}

The constant diminution of fresh water supplies and the need to apply sustainability criteria to those natural resources that do exist is leading to the growing use of low quality water for irrigation purposes, the production of ornamental plants being no exception. It is common for subterranean waters and water from treatment plants to contain high salt levels, particularly in semiarid areas, so that the identification of salt-tolerant species and the development of efficient irrigation practices are urgent.

The general aim of this thesis is to optimize the management of irrigation with salt water by designing precise irrigation strategies based on automatic tools that continuously inform growers in real time of the water and saline status the medium in which the plants are grown. Such strategies are studied in the nursery production (in pots) of ornamental plants of high commercial interest, such as Pelargonium hortorum, Gerbera hybrida, Osteospermun hybrida, Ficus benjamina and Euphorbia pulcherrima.

Five experiments were carried out using saline irrigation water and the above potted ornamental plants. The first studied the possibility of managing irrigation using gravimetric methods (programmable balances) and different leachate criteria. The second looked at the possibility of using electrical conductivity (EC) of the pore water estimated by soil moisture and EC sensor (GS3-Decagon) to maintain different levels of substrate salinity. The third experiment evaluated the efficacy and characteristics of using indicators other than pore water EC based on parameters directly measured by the sensor, in the present case the EC of the bulk. In the fourth experiment, the relationships between the different EC levels that can be measured during growing period were studied, in order to improve irrigation management using soil moisture and EC and to predict plant responses to salinity. The final experiment was designed to increase our knowledge of the distribution of salts and roots in the root ball of pot-grown plants when the same volume of water is applied to the pots using a different number of emitters.

In all these experiments, plants were analysed for growth and development (production of biomass, dimensions, ornamental quality, root growth and relative leaf chlorophyll content), water consumption (saline, non-saline, water use efficiency and evapotranspiration), leachate (salinity and leaching fraction), ion accumulation (areal and root parts), gas exchange (stomatal conductance and net photosynthesis rate), chlorophyll fluorescence (efficiency of photosystem II, non-photochemical quenching and electron transport rate) and EC (evolution, mean, specific and isolated values). 
The results showed that the use of programmable balances permits the precise control of irrigation as long as the substrates used are structurally stable and have a good rehydration capacity. The management of automatic irrigation based on the estimation of pore water EC by standard recordings of the soil sensor was able to maintain the different levels of salinity up to a fixed mean threshold of pore water EC of $5.5 \mathrm{dS} \mathrm{m}^{-1}$. Despite the strong influence of substrate moisture on the EC of the bulk, our results suggest that the use of this EC may be useful for controlling substrate salinity levels, and that the success of the same depends on looking for the best indicators calculated with the selected measurements (just after irrigating, falling slope of values after irrigating, etc.). The measurement of leachate EC overestimates the real salinity of the soil solution, while pore water EC, as estimated by the GS3, sensor underestimates it. Estimates of pore water EC using the Hillhorst model are imprecise because of the influence of salinity, moisture and temperature. The use of mean pore water values between consecutive applications of irrigation water is more suitable for controlling substrate salinity than using isolated values. The use of more than one emitter per pot improves plant growth and development and reduces saline damage because of the better distribution of roots and salts in the substrate.

The appropriate use of soil sensors provides precise and continuous knowledge of substrate moisture and salinity. As a consequence, the efficiency of irrigation improves considerably because cultivation costs are reduced, as is the use of an increasingly rare resource - fresh water. 


\section{RESUMEN}

La constante disminución del agua fresca y la necesidad acuciante de aplicar criterios de sostenibilidad en el uso de los recursos naturales, nos está empujando hacia un riego con aguas de baja calidad, en donde la producción de plantas ornamentales es una actividad potencialmente receptora de estas aguas. Es frecuente que las aguas subterráneas y las residuales depuradas contengan cantidades altas de sales, especialmente en las zonas semiáridas, lo que crea la necesidad urgente de identificar las especies vegetales que puedan crecer bien en estas condiciones, y de desarrollar sistemas de gestión del riego más eficientes. El objetivo general de esta tesis es optimizar el manejo del riego salino mediante el diseño de estrategias de riego de precisión apoyados en herramientas automáticas que informen a tiempo real y continuamente del estado hídrico y salino que soportan las plantas. Estas estrategias se han estudiado en la producción viverística de plantas ornamentales en maceta, concretamente en cultivos con interés comercial como Pelargonium hortorum, Gerbera hybrida, Osteospermun hybrida, Ficus benjamina y Euphorbia pulcherrima.

Se realizaron cinco experimentos bajo riego salino y con plantas ornamentales en maceta. El primero estudió las posibilidades del manejo del riego por medidas gravimétricas de la maceta (balanzas programables) bajo distintos criterios de drenaje. Con el segundo, pretendimos valorar las posibilidades de usar la conductividad eléctrica (CE) del agua de los poros estimada por un sensor de humedad y CE de suelo (GS3Decagon) para mantener distintos niveles de salinización en la solución del sustrato. En el tercero, se valora la eficacia y las características del uso de indicadores de la salinidad alternativos a la CE del agua de los poros estimada, basados en parámetros medidos directamente por el sensor como es la CE del medio. En el cuarto experimento estudiamos las relaciones entre las distintas conductividades eléctricas que podemos medir durante un cultivo en maceta, con el objetivo de mejorar el manejo del riego con sensores de humedad y CE de suelo y predecir la respuesta a la salinidad de las plantas. El último de los ensayos pretende avanzar en el conocimiento de la distribución de sales y raíces en el cepellón de plantas cultivadas en maceta, cuando aplicamos el mismo volumen de agua con distintos número de goteros por maceta.

Todos estos estudios se evaluaron en términos de crecimiento y desarrollo de las plantas (producción de biomasa, dimensión de planta, calidad ornamental, crecimiento radicular y contenido relativo de clorofila foliar), de consumo de agua (salina, no salina, 
eficiencia del uso del agua y evapotranspiración), drenaje (salinidad y porcentajes de lavado), acumulación de iones (parte aérea y radicular), intercambio gaseoso (conductancia estomática y fotosíntesis), fluorescencia clorofílica (eficiencias del fotosistema II, decaimiento no fotoquímico y tasa de transferencia de electrones) y medidas de conductividades eléctricas (evoluciones, promedios, medidas específicas o puntuales).

Los resultados indican que el uso de balanzas programables permite hacer un control preciso del riego siempre que los sustratos usados sean estables estructuralmente y con buena capacidad de rehidratación. El manejo del riego automático basado en la estimación de la CE del agua de los poros con los registros estándares del sensor de suelo, fue capaz de mantener diferentes condiciones de salinidad de hasta un umbral fijado de CE del agua de los poros promedio de 5,5 $\mathrm{dS} \mathrm{m}^{-1}$. A pesar de la fuerte influencia de la humedad del sustrato sobre la CE del medio, nuestros resultados sugieren que el uso de esta conductividad puede ser una herramienta útil para controlar la salinidad en el sustrato, y que el éxito radicará en buscar los mejores indicadores calculados con medidas seleccionadas (justo después del riego, pendiente de descenso de los valores tras el riego, etc.). La medida de la CE del drenaje sobreestima la salinidad real de la solución del suelo, mientras que la CE del agua de los poros estimada por el sensor GS3 la subestima. La estimación de la CE del agua de los poros por el modelo de Hilhorst es poco precisa por la influencia de la salinidad, humedad y temperatura. El uso de valores promedios de CE del agua de los poros entre dos riegos consecutivos es más apropiado que el uso de valores puntuales, para el control de la salinidad en el sustrato. El uso de más de un emisor por maceta mejora el crecimiento y desarrollo y reduce la presencia de daños salinos en las plantas, porque mejora la distribución de raíces y sales en el sustrato.

Un apropiado uso de los sensores de suelo conduce a un conocimiento preciso y continuo de la humedad y salinidad del sustrato. Como consecuencia, la eficiencia del riego aumenta considerablemente porque reducimos los costes de cultivo y mejoramos la preservación de un recurso natural escaso como es el agua de buena calidad. 
INDEX 


\section{INDEX}

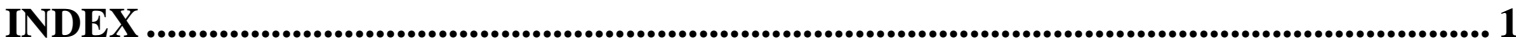

TABLE INDEX

FIGURE INDEX

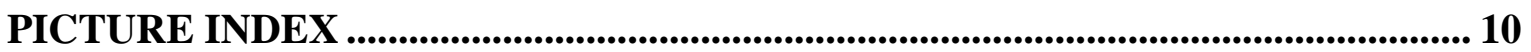

\section{OBJECTIVES AND BACKGROUND}

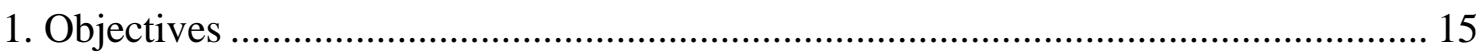

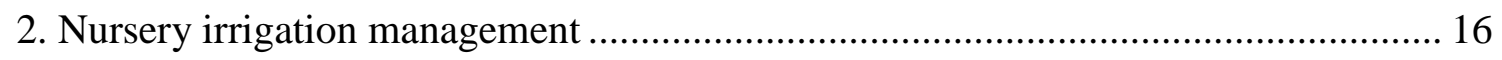

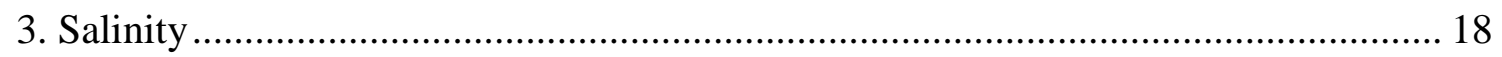

4. Soil electrical conductivity and moisture sensors.................................................... 20

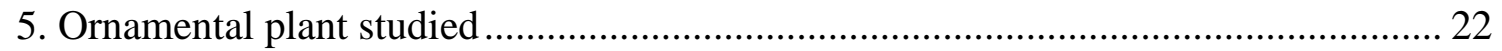

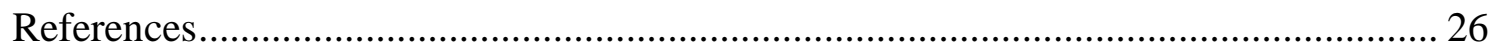

Chapter 1: Saline reclaimed wastewater can be used to produce potted weeping fig (Ficus benjamina L.) with minimal effects on plant quality ....................................... 33

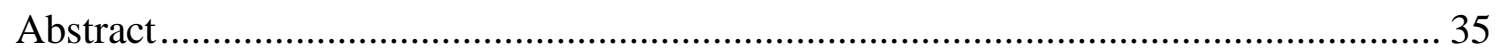

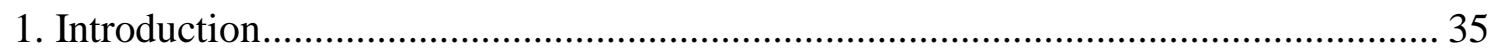

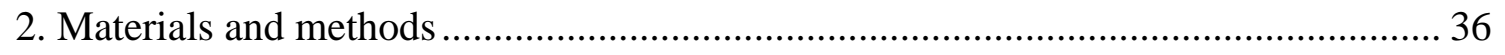

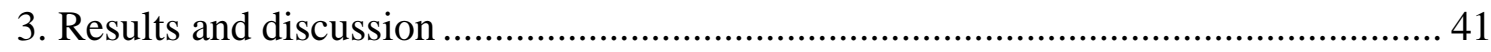

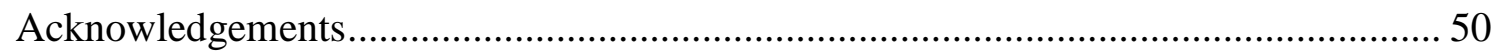

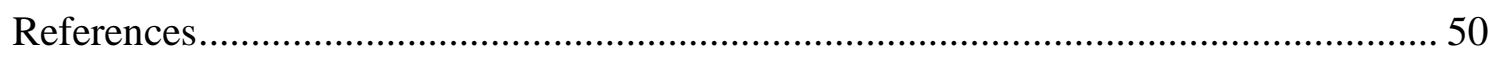

Chapter 2: Saline irrigation scheduling for potted geranium based on soil electrical conductivity and moisture sensors .......................................................................5 53

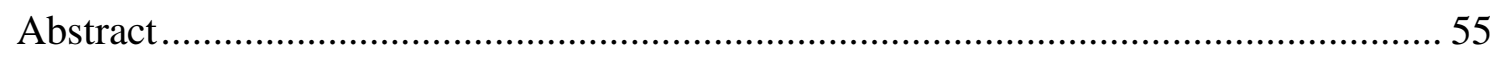

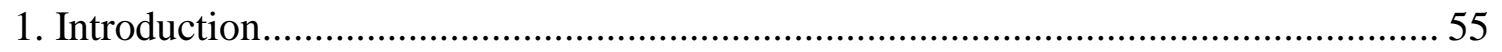

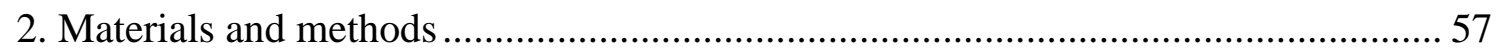

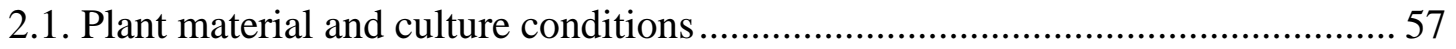

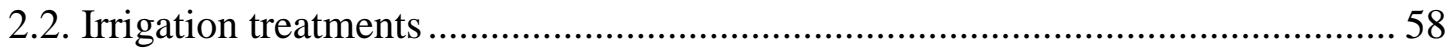

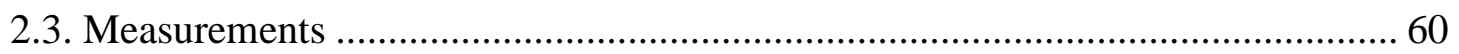

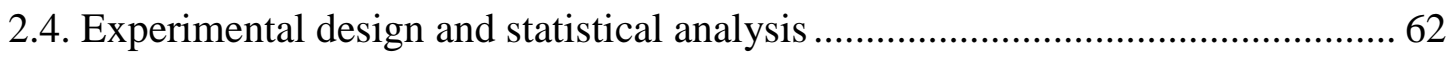




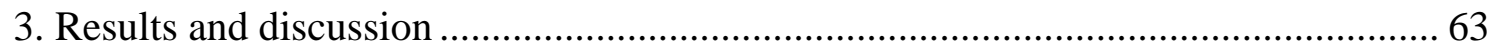

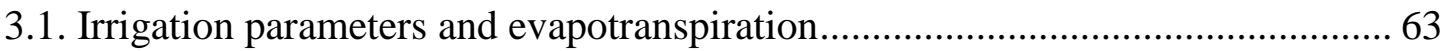

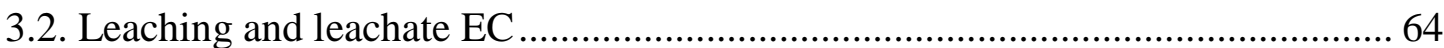

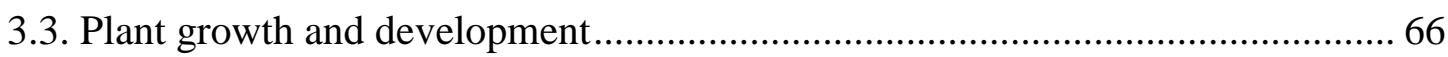

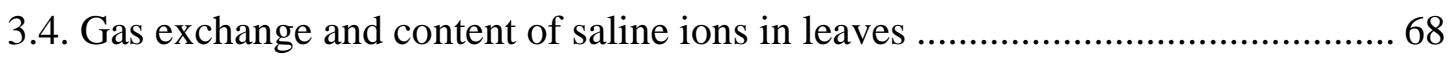

3.5. Relationships among pore water EC, bulk EC and 1:2 extract EC ..................... 69

3.6. Evolution of the volumetric water content and EC in substrate........................... 71

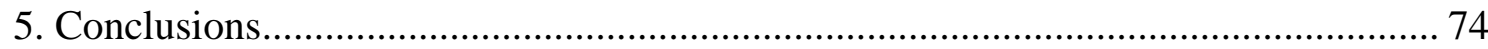

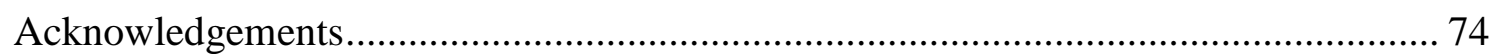

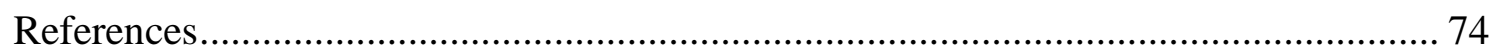

Chapter 3: Using soil bulk electrical conductivity to manage saline irrigation in the production of potted poinsettia ......................................................................................................... 79

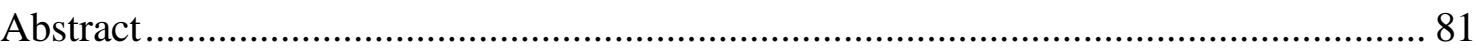

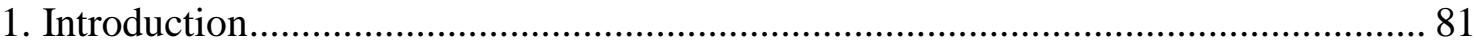

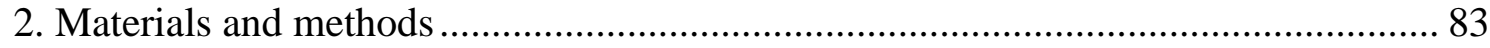

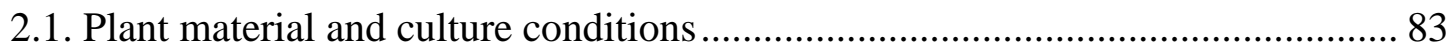

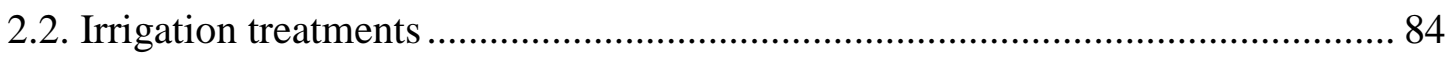

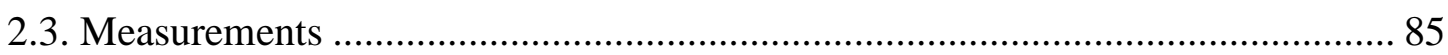

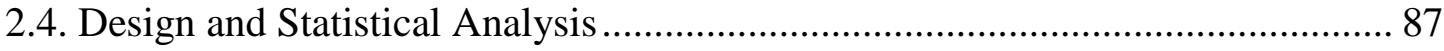

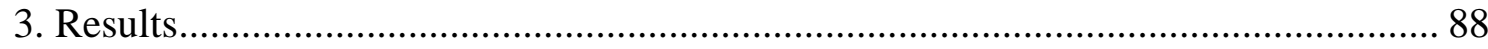

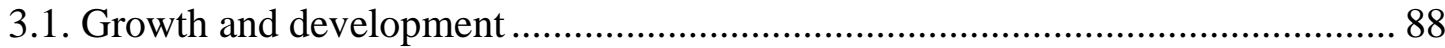

3.2. Plant water status and gas exchange .............................................................. 91

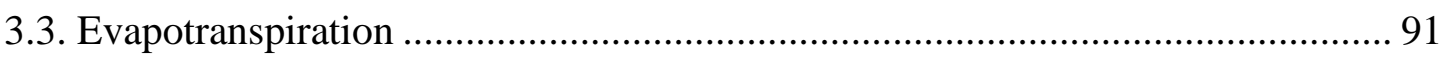

3.4. Applied water, number of irrigations, leaching fraction and IWUE ................... 92

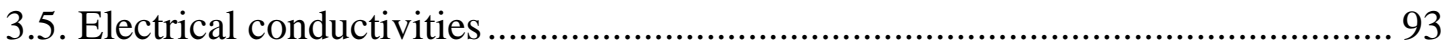

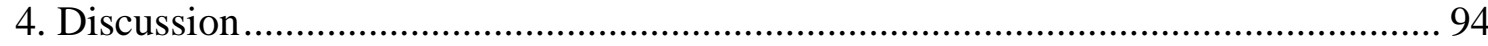

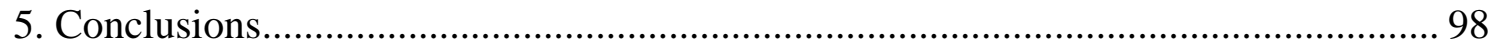

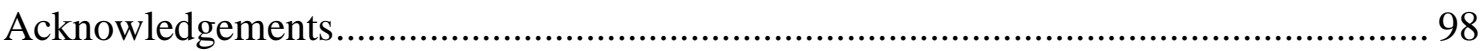

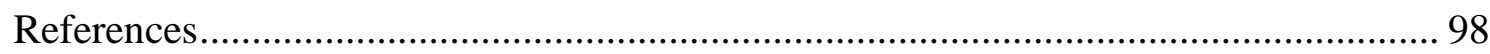

Chapter 4: Relationships among electrical conductivities under salinizing irrigation for potted osteospermum ..................................................................................................................... 103

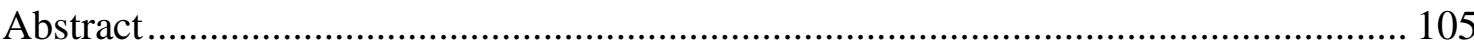

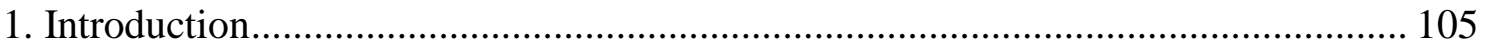




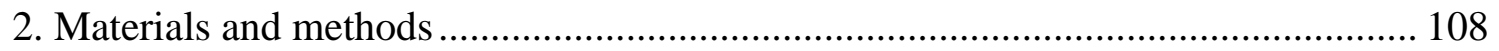

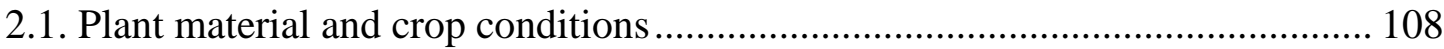

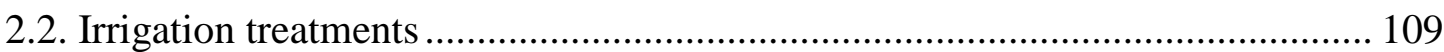

2.3. Measurements of EC using the pour-through method ................................... 110

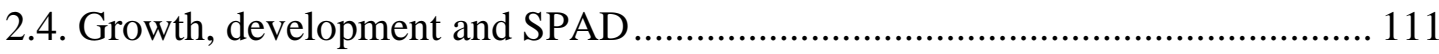

2.5. Contents of chloride, sodium and potassium in plant ..................................... 111

2.6. Design and statistical analysis................................................................... 112

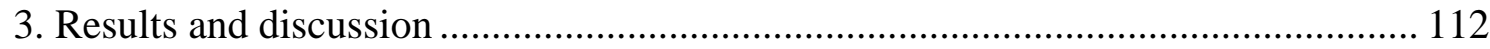

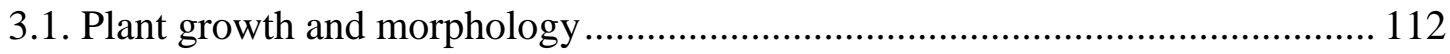

3.2. Contents of chloride, sodium and potassium in plant .................................. 114

3.3. Effect of increasing $\mathrm{EC}_{\mathrm{IW}}$ on the mean electrical conductivities values........... 115

3.4. Relationships among electrical conductivities ............................................... 117

3.5. Evolution of the substrate $\theta, \mathrm{EC}_{\mathrm{PW}}$ and $\mathrm{EC}_{\mathrm{B}}$ obtained using the $\mathrm{GS} 3$ sensor .... 119

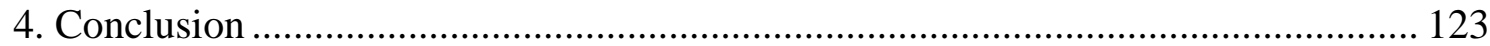

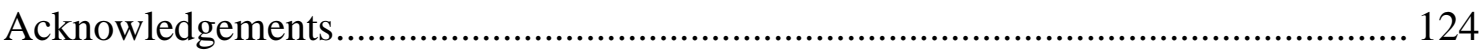

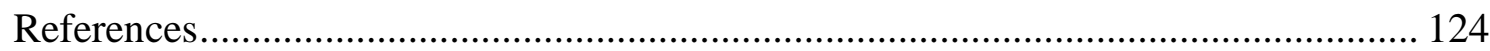

Chapter 5: The number of emitters alters salt distribution and root growth in potted

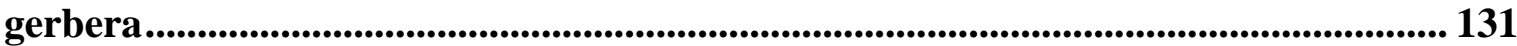

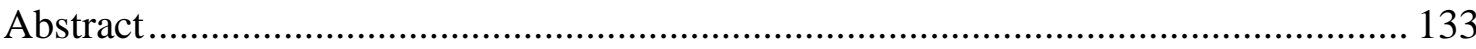

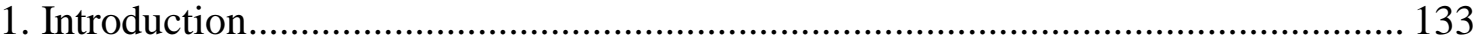

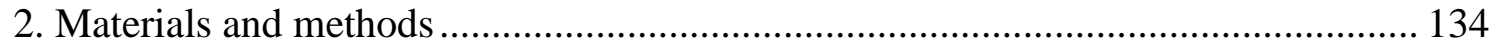

2.1. Plant material and growing conditions............................................................ 134

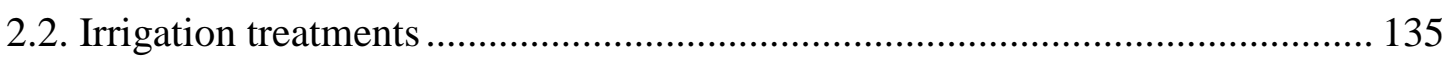

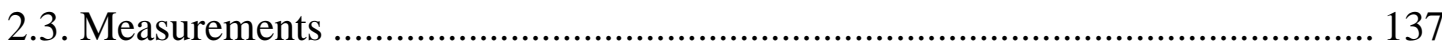

2.4. Distribution of salt and $\mathrm{pH}$ in substrate ......................................................... 139

2.5. Statistical analysis and experimental design .................................................. 139

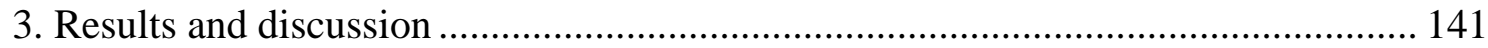

3.1. Shoot growth, leaf damage and number of inflorescences ............................. 141

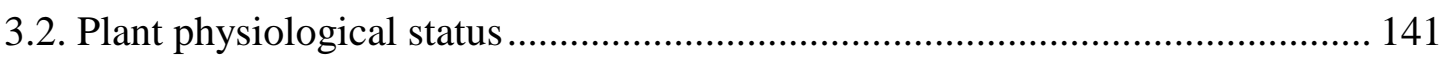

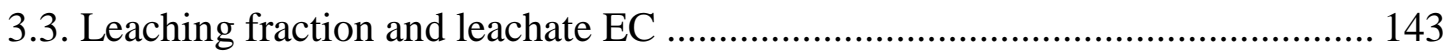

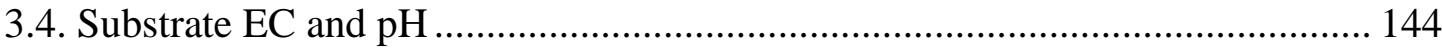

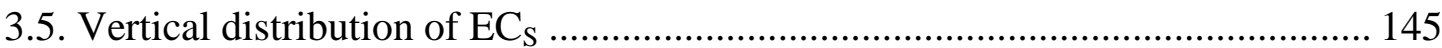

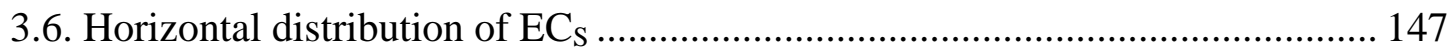


3.7. Root growth and horizontal distribution of roots in root ball .......................... 148

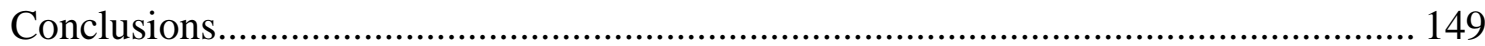

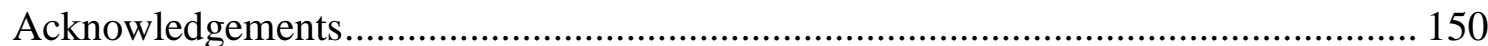

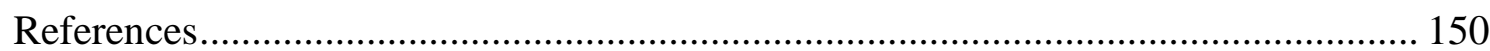

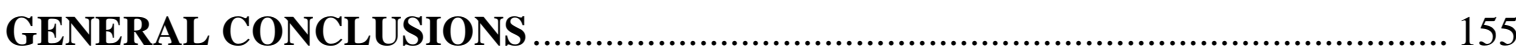




\section{TABLE INDEX}

Chapter 1: Saline reclaimed wastewater can be used to produce potted weeping fig (Ficus benjamina L.) with minimal effects on plant quality

Table 1. Effects of irrigation treatments on variables/parameters studied 44

Chapter 2: Saline irrigation scheduling for potted geranium based on soil electrical conductivity and moisture sensors

Table 1. Ion concentrations $\left(\mathrm{mg} \mathrm{L}^{-1}\right)$ of fresh water and saline recycled wastewater $(\mathrm{SRW})$

Table 2. Applied water and the number of irrigation events for each treatment during the experimental period.

Table 3. Effect of increasing $\mathrm{EC}_{\mathrm{PW}}$ threshold on leaching, aerial and root growth, leaf SPAD value, gas exchange and leaf chloride and sodium concentration of Pelargonium $\mathrm{x}$ hortorum "Master Idols Red" at the end of the experiment

Chapter 3: Using soil bulk electrical conductivity to manage saline irrigation in the production of potted poinsettia

Table 1. Growth, development and leaf SPAD.

Table 2. Water relations and gas exchange

Table 3. Applied water, irrigating, leaching, IWUE and EC.

Chapter 4: Relationships among electrical conductivities under salinizing irrigation for potted osteospermum

Table 1. Linear regression models for growth parameters, plant content of ions and irrigation water electrical conductivity $\left(\mathrm{EC}_{\mathrm{IW}}\right)$.

Table 2. Evolution of bulk EC values (each half hour) following irrigation. Linear fits for eight levels of $\mathrm{EC}_{\mathrm{IW}}$ are shown. Bulk EC data were collected from the 22 of December of 2013 to 3 of January of 2014 (between two irrigation events). $y=$ bulk EC and $x=$ time after the irrigation event. 120 
Chapter 5: The number of emitters alters salt distribution and root growth in potted gerbera

Table 1. Effects of salinity and the number of emitters per pot on the parameters studied when interaction was significant. 142

Table 2. Effects of salinity and the number of emitters per pot on the parameters studied when the interaction between both factors was not significant. 143 


\section{FIGURE INDEX}

Chapter 1: Saline reclaimed wastewater can be used to produce potted weeping fig (Ficus benjamina L.) with minimal effects on plant quality

Figure 1. Thirty representative days of pot weight evolution at the beginning of experiment (from 1-March to 30-March) (A), and at the end of the experiment (from 10June to 10-July) (B). Saline reclaimed wastewater with a constant leaching fraction of $23 \%$ (RWL); saline reclaimed wastewater with a constant leaching fraction of $15 \%$ and flushing of $50 \%$ every nine irrigation events (RWF); water taken from a canal that delivers water from the Tagus River to the Segura River for agricultural and municipal use with a constant leaching fraction of about $15 \%$ (control). Vertical bars indicate SE ( $\mathrm{n}=3$ ) .46

Figure 2. Daily evapotranspiration (ET) as a function of days of culture (days) and day light integral (DLI) for control (A), saline reclaimed wastewater (5 dS m-1) with a constant leaching fraction of $23 \%(\mathrm{RWL})(\mathrm{B})$, and saline reclaimed wastewater with a constant leaching fraction of $15 \%$ and flushing of $50 \%$ every nine irrigation events (RWF) (C). The continuous regression curves (open circle) indicate days vs. ET and discontinuous regression curves (filled circle) indicate DLI vs. ET.

\section{Chapter 2: Saline irrigation scheduling for potted geranium based on soil electrical conductivity and moisture sensors}

Figure 1. Evolution of the accumulated evapotranspiration throughout the experiment for five thresholds of $\mathrm{EC}_{\mathrm{PW}}$.

Figure 2. The relationship between bulk EC (measured by GS3-Sensor) and 1:2 soil-water extract EC (A) and the relationship between estimated pore water EC (model of Hilhorst) and 1:2 soil-water extract EC $(B)$. The points $(n=3)$ were obtained at different substrate salinity and moisture conditions. 70

Figure 3. Values of average EC throughout the growing cycle. $\mathrm{EC}_{\mathrm{PW}} \mathrm{TC}$ (determined throughout the cycle as the mean of all the $\mathrm{EC}_{\mathrm{PW}}$ recordings stored every 30 minutes) and $\mathrm{EC}_{\mathrm{B}} \mathrm{TC}$ (determined throughout the cycle as the mean of all the $\mathrm{EC}_{\mathrm{B}}$ recordings stored every 30 minutes). $\mathrm{EC}_{1: 2 \mathrm{E}} \mathrm{TC}$ from $\mathrm{EC}_{\mathrm{PW}}(1: 2$ soil-water extract $\mathrm{EC}$ values predict from $\left.\mathrm{EC}_{\mathrm{PW}}\right) . \mathrm{EC}_{1: 2 \mathrm{E}} \mathrm{TC}$ from $\mathrm{EC}_{\mathrm{B}}\left(1: 2\right.$ soil-water extract $\mathrm{EC}$ values predict from $\left.\mathrm{EC}_{\mathrm{B}}\right)$ 71

Figure 4. Evolution of volumetric water content, pore water EC and bulk EC. The control, irrigation with fresh water (A), saline irrigation with fresh water flushing every time that a 
threshold of $\mathrm{EC}_{\mathrm{PW}} 5 \mathrm{dS} \mathrm{m}^{-1}$ was exceeded (B) and saline irrigation with fresh water flushing every time that a threshold of $\mathrm{EC}_{\mathrm{PW}} 6.5 \mathrm{dS} \mathrm{m}^{-1}$ was exceeded (C). Two periods of the cycle of cultivation are shown, from 25 April to 15 May and from 15 June to 6 July.

Chapter 3: Using soil bulk electrical conductivity to manage saline irrigation in the production of potted poinsettia

Figure 1. Daily evolution of accumulated evapotranspiration (ET) during the experiment. Vertical bars show LSD at $\mathrm{P}<0.05$ 92

Figure 2. Evolution of bulk $\mathrm{EC}$ after irrigation finished $\left(\mathrm{EC}_{\mathrm{BAI}}\right)$ during the experiment. The $\mathrm{EC}_{\mathrm{B}}$ values shown refer to the mean of the ten values recorded $30 \mathrm{~min}$ after irrigation or flushing finished. Vertical bars show LSD at $\mathrm{P}<0.05$. Horizontal lines mark the three ECB thresholds fixed for flushing. 94

\section{Chapter 4: Relationships among electrical conductivities under salinizing irrigation for potted osteospermum}

Figure 1. Changes in leachate $\mathrm{EC}\left(\mathrm{EC}_{\mathrm{L}}\right)$, Pour-Through pore water $\mathrm{EC}\left(\mathrm{EC}_{\mathrm{PW}} \mathrm{PT}\right), \mathrm{GS} 3$ pore water $\mathrm{EC}\left(\mathrm{EC}_{\mathrm{PW}} \mathrm{GS} 3\right)$ with irrigation water $\mathrm{EC}$. The data shown are mean values of throughout the growing cycle. $* * *$ indicates significant at $P<0.001$. 116

Figure 2. Linear fit between pour-through pore water $\mathrm{EC}\left(\mathrm{EC}_{\mathrm{PW}} \mathrm{PT}\right)$, leachate $\mathrm{EC}\left(\mathrm{EC}_{\mathrm{L}}\right)$, GS3 pore water $\mathrm{EC}\left(\mathrm{EC}_{\mathrm{PW}} \mathrm{GS} 3\right)$ and bulk $\mathrm{EC}\left(\mathrm{EC}_{\mathrm{B}}\right)$. *** indicates significant at $P<0.001$.

Figure 3. Linear fit between bulk $\mathrm{EC}\left(\mathrm{EC}_{\mathrm{B}}\right)$ and pore water $\mathrm{EC}\left(\mathrm{EC}_{\mathrm{PW}} \mathrm{GS} 3\right)$ before and after irrigation. $* * *$ indicates significant at $P<0.001$.

Figure 4. Evolution of substrate volumetric water content (solid black line), pore water EC (solid grey line) and bulk EC (dotted grey line) from the 14 of December of 2013 to 23 of January of 2014. EC $\mathrm{EW}_{\mathrm{IW}} 1.5 \mathrm{dS} \mathrm{m}{ }^{-1}$ (A); $\mathrm{EC}_{\mathrm{IW}} 2 \mathrm{dS} \mathrm{m}^{-1}$ (B); $\mathrm{EC}_{\mathrm{IW}} 2.5 \mathrm{dS} \mathrm{m}^{-1}$ (C); $\mathrm{EC}_{\mathrm{IW}} 3$ $\mathrm{dS} \mathrm{m}{ }^{-1}(\mathrm{D}) ; \mathrm{EC}_{\mathrm{IW}} 3.5 \mathrm{dS} \mathrm{m}^{-1}(\mathrm{E}) ; \mathrm{EC}_{\mathrm{IW}} 4 \mathrm{dS} \mathrm{m}{ }^{-1}(\mathrm{~F}) ; \mathrm{EC}_{\mathrm{IW}} 4.5 \mathrm{dS} \mathrm{m}^{-1}(\mathrm{G})$ and $\mathrm{EC}_{\mathrm{IW}} 5 \mathrm{dS}$ $\mathrm{m}^{-1}(\mathrm{H})$. 121

Figure 5. Evolution of substrate volumetric water content (black thick solid line), pore water EC (black thin solid line), bulk EC (grey solid line) and substrate temperature (grey dotted line) between two irrigation events (from the 22 of December of 2013 to 3 of January of 2014). $\mathrm{EC}_{\mathrm{IW}} 1.5 \mathrm{dS} \mathrm{m}^{-1}$ (A) and $\mathrm{EC}_{\mathrm{IW}} 5 \mathrm{dS} \mathrm{m}^{-1}$ (B). 
Figure 6. Linear relationships between number of irrigation applied and the average $\mathrm{EC}_{\mathrm{PW}} \mathrm{GS} 3$ obtained from recorded data between two irrigation events. 123

Chapter 5: The number of emitters alters salt distribution and root growth in potted gerbera

Figure 1. Electrical conductivity (EC) and root distribution in the root ball. A) Vertical EC gradient with an irrigation solution of $1.5 \mathrm{dS} \mathrm{m}^{-1}$, B) Vertical EC gradient with an irrigation solution of $3 \mathrm{dS} \mathrm{m}^{-1}$, C) Horizontal EC gradient with an irrigation solution of 1.5 $\mathrm{dS} \mathrm{m}^{-1}$, D) Horizontal EC gradient with an irrigation solution of $3 \mathrm{dS} \mathrm{m}{ }^{-1}$, E) Horizontal root distribution with an irrigation solution of $1.5 \mathrm{dS} \mathrm{m}^{-1}, \mathrm{~F}$ ) Horizontal root distribution with an irrigation solution of $3 \mathrm{dS} \mathrm{m}^{-1}$. Vertical bars show LSD at $\mathrm{P}<0.05 \ldots \ldots \ldots \ldots \ldots . . . . .146$

Figure 2. Coefficient of variation $(\mathrm{CV})$ of the substrate $\mathrm{EC}$ in the root ball for the six treatments studied.

Figure 3. Regression analysis between root growth index (RGI) and substrate EC (EC $)$ 


\section{PICTURE INDEX}

Chapter 1: Saline reclaimed wastewater can be used to produce potted weeping fig (Ficus benjamina L.) with minimal effects on plant quality

Picture 1. Detail of system irrigation with programmable balance at the beginning and at the end of the cultivation cycle.

Picture 2. Ficus benjamina at the end of the experiment. From left to right control, saline reclaimed wastewater with a constant leaching (RWL) and saline reclaimed wastewater with flushing every nine irrigation events (RWF).

Chapter 2: Saline irrigation scheduling for potted geranium based on soil electrical conductivity and moisture sensors

Picture 1. Details of the position of the GS3 sensor and emitters 59

Picture 2. Details of the measurement of leaf area and SPAD 62

Picture 3. The developmental state of the plants at the end of the experiment 67

Picture 4. Cultivation at the end of the experiment 68

Chapter 3: Using soil bulk electrical conductivity to manage saline irrigation in the production of potted poinsettia

Picture 1. Details of the position of the HPII sensor and emitters 85

Picture 2. Details of the measurement of gas exchange and leaf water potential 87

Picture 3. Poinsettia at the end of the experiment. From left to right control, saline irrigation with flushing when an $\mathrm{EC}_{\mathrm{B}}$ of $1.5 \mathrm{dS} \mathrm{m}{ }^{-1}$ was exceeded $\left(\mathrm{T}_{1.5}\right)$, saline irrigation with flushing when an $\mathrm{EC}_{\mathrm{B}}$ of $2 \mathrm{dS} \mathrm{m} \mathrm{m}^{-1}$ was exceeded $\left(\mathrm{T}_{2}\right)$ and saline irrigation with flushing when an $\mathrm{EC}_{\mathrm{B}}$ of $2.5 \mathrm{dS} \mathrm{m}{ }^{-1}$ was exceeded $\left(\mathrm{T}_{2.5}\right)$ 90

Picture 4. Damage in the basal leaves in $\mathrm{T}_{2.5}$. 90

Chapter 4: Relationships among electrical conductivities under salinizing irrigation for potted osteospermum

Picture 1. An overview of the greenhouse, which shows tables for different treatments and leachate collection system 109

Picture 2. Plants in the flowering phase at the end of experiment 114 
Chapter 5: The number of emitters alters salt distribution and root growth in potted gerbera

Picture 1. The position of the emitters for different treatments. From left to right one, two and four emitters 136

Picture 2. Measurement of roots with the image analysis software ASSESS 2.0.......... 138

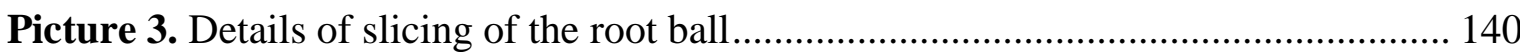

Picture 4. An overview of the greenhouse, which shows tables for different treatments and data logger 140 
OBJECTIVES AND BACKGROUND 


\section{Objectives}

Ornamental horticulture has experienced rapid expansion in recent decades, with substantial development in gardening and landscaping. However, the sector faces threats, such as the scarcity of good quality water and the need for more sustainable production practices, without losing economic viability. Such threats can be reduced by incorporating new technologies, which include soil electrical conductivity (EC) and moisture sensors and data-loggers to enable more accurate irrigation management. Technological innovation is the key to increased productivity and competitiveness in the sector.

The overall objective of the thesis focuses on optimizing the management of saline irrigation through the design of more accurate irrigation strategies, supported by using automatic tools that continuously report, in real time, the state of the substrate water and the salt content. For this, we consider several specific points:

- Studies of the limitations of irrigating with saline water to produce ornamental potted plants.

- The correct use of balances and soil moisture and EC sensors.

- Understanding the limitations of sensors and improving our interpretation of their outputs.

- Evaluation of the effectiveness of using sensor-estimated pore water EC and bulk EC to control substrate salinity.

- Establishing different scheduling strategies with saline irrigation in order to minimize salt damage to plants.

- Determination of the relationships among electrical conductivities, both those measured in situ and those measured by sensors.

- Assessment of the effects of cultivation conditions when measuring electrical conductivities.

- A study of the effect of the number of emitters per pot on plant growth, leaching and the distribution of salts and roots in the root ball. 


\section{Nursery irrigation management}

Water is essential to plant life and is a critical input to nursery crop production. For plants, water is used in temperature regulation, as a carrier for nutrients and plant hormones, and is the hydraulic force behind growth. A water deficit can negatively affect plant growth, plant health and the amount of time needed to grow a crop to a marketable size. Irrigation can shorten the production period for ornamental crops and increase quality, which has a positive impact on nursery profitability. Because the nursery industry has shifted from primarily field-produced crops to container produced crops, the need for irrigation is increasing (Fulcher and Fernandez, 2013a).

Nurseries have two main strategies for alleviating competition for water: to improve irrigation efficiency and the use of alternative water sources, possibly low quality water. Many practices can improve efficiency of water use, including irrigation scheduling, irrigation system selection and delivery, adjusting irrigation volume, substrate composition, pot size and shape, and plant spacing (Bilderback, 2002; Fulcher and Fernandez, 2013a). However, an inefficient irrigation wastes water and nutrients, increases water runoff and movement of contaminants in runoff; increased biotic and abiotic stresses; reduced plant growth and increased production duration.

Irrigation scheduling in ornamental plant production is complex due to the large number of species grown and great variety in size of container (Belayneh et al., 2013). Irrigation scheduling involves deciding when and how much water to apply (Warren and Bilderback, 2005). Although irrigation control in ornamental production is commonly achieved with timers and/or with the experiential judgment of an irrigation manager, such methods are unlikely to provide water when needed and in the amount required by the crop (Fare et al., 1992; Bacci et al., 2008; Jones, 2008; van Iersel et al., 2013). Therefore, irrigation is not adjusted often for changes in evaporative demand due to weather changes, but rather is limited to gross changes when the seasons change. Good scheduling will apply water at the right time and in the right quantity in order to optimise production and minimise adverse environmental impacts.

Substrate moisture-based systems for container production include applying irrigation based on measures gravimetric or estimated by substrate moisture probes (Garcia-Navarro et al., 2011; Warsaw et al., 2009). Sensor networks and water use models have been suggested as ways to improve irrigation efficiency and reduce water use in 
ornamental horticulture (Lea-Cox, 2012; Million et al., 2010). The use of substrate moisture sensors to initiate irrigation based on set points (that are not established on a specific physiological relationship) is quite well developed (Burnett and van Iersel, 2008; Grant et al., 2009; Miralles and van Iersel, 2011). Currently, scientists are developing aspects such as the ideal probe number per container, number of containers with probes per crop, probe orientation and probe placement within containers (Hagen, 2013; van Iersel et al., 2009a). However, studies at nurseries have shown that a very small number of probes involving modest financial investment can be effective in reducing water use without sacrificing plant quality or time to produce a crop.

Irrigation scheduling relies on gravimetric measurements (weighing the potted) quantify the amount of water that is lost by evapotranspiration. In this method normally is applied irrigation with an amount equivalent to the accumulated evapotranspiration losses since the last irrigation (Mathers et al., 2005). This may be related to percentage of easily available water in the substrate.

Leaf temperature, plant water potential and stem diameter fluctuations are some of the plant-based techniques that have been used to assess water loss in potted crops. These systems can be accurate but are difficult to automate and are not yet widely available in the marketplace (Fulcher et al., 2012).

Another point to consider is how much water to apply; it can be based on the pot leachate. Leaching fraction is the percentage of water applied that leaches or drains out of the pot. A leaching fraction of ten percent or less allows for water and nutrient conservation. When irrigating at low leaching fractions, it is important to take into account salts concentration in the substrate, especially with saline irrigation. These aspects have been studied extensively, perhaps to a lesser extent as a tool of reducing the effect of saline water in the root zone in combination with the use of soil moisture sensors.

There are various types of irrigation systems have been developed for potted crops. The most widely used are the surface system (drip-irrigation), subirrigation and overhead irrigation (Reed, 1996). Drip irrigation is the most used in nursery production due to numerous advantages, such as high levels of water-use efficiency, fertilizers loss is minimized due to localized application and reduced leaching, recycled wastewater can be safely used, etc. However, this system has some disadvantages as single-point delivery of 
a drip emitter can lead to water channeling through the substrate and to lead to different moisture conditions and high installation costs (Fulcher and Fernandez et al, 2013b).

\section{Salinity}

Global water availability is a current issue for agriculture, since water demand is increasing worldwide due to fast population growth rates, improvement in living standards, expansion of irrigation schemes and global warming, but the availability of fresh water is diminishing (Turral et al., 2011). This is leading to the use of alternative irrigation sources to irrigate both urban landscape and agricultural crops (Feigin et al., 1991). One of these alternatives is to use of low-quality water, such as saline and recycled wastewater. In the context of horticulture and landscape irrigation, water quality is evaluated as a function of the concentration of total salts as well as the concentration of several specific ions (chloride, sodium, boron), bicarbonate, $\mathrm{pH}$, trace elements, and nutrients (nitrogen, phosphorus, potassium). In this narrow sense, good quality water has relatively few salts, while poor quality water has higher concentrations. Sources of poorer quality waters include groundwater and, specially, municipal wastewater treatment plants. Reclaimed wastewater is usually of poor quality compared with fresh water, but its chemical composition varies with treatment processes, source waters, location, and time of year (Niu and Cabrera, 2010). In the southeast on the Iberian Peninsula reclaimed municipal wastewater may have high salt content when it comes from treatment plants located near the Mediterranean coast (Bañón et al., 2011). Reclaimed wastewater may contain high concentrations of sodium, chloride and boron, heavy metals or pathogenic organisms (Brar et al., 2000; Yadav et al., 2002). However, the use of reclaimed wastewater to irrigation can have positive too, because it can contain some nutrients essential for plant growth and therefore it may be possible to reduce fertilizer application. Other benefits of using recycled water to grow floricultural plants are water conservation, organic matter savings, energy conservation, a favourable public image, protection of the environment, conservation of resource and low risks for human health from contamination with toxic elements as they are not used as food (Skimina, 1992; Carter and Grieve, 2008).

The high levels of salt in water may become an important problem when it is used for irrigation. The degree of the problem depends on the sensitivity of the plant to salts and the concentration of the accumulated salts in the medium. Irrigating with saline water 
leads to the accumulation of salt in the root zone (Miyamoto et al., 2005; Niu and Rodriguez, 2006a,b). In potted plant, salt accumulation in the root zone is affected by the physical and chemical properties of the substrate, plant size, environmental conditions, irrigation frequency, leaching fraction because these factors influence the substrate moisture content and cation exchange capacity in the root zone (Niu et al., 2010). Salt toxicity is first expressed as stunting of growth and yellowing of foliage. As more salts are taken up by the plant, burning of the edge of the leaves and defoliation may develop, causing a decrease the quality and landscape value of plants (Shannon and Grieve, 1999; Morales et al., 2001). These phenomena occur due to the disturbance that high salt concentrations cause to, among other things, membrane permeability, water channel activity, stomatal conductance, photosynthesis and ion balance (Sonneveldt, 1988; Carvajal et al., 1999; Navarro et al., 2003; Cabañero et al., 2004). Ion toxicities or nutritional deficiencies may arise because of competition between cations or anions (Shannon and Grieve, 1999). When $\mathrm{Na}^{+}$and $\mathrm{Cl}^{-}$are present in the rhizosphere, they can disrupt the uptake of nutrients directly by interfering with transporters, such as those for $\mathrm{K}^{+}$and $\mathrm{NO}_{3}^{-}$in the root plasma membrane (Tester and Davenport, 2003) or, if accumulated and not compartmentalised in vacuoles, can be metabolically toxic, resulting in "scorched" or "burned" leaves (Shannon and Grieve, 1999). In addition high external salt concentrations can inhibit root growth by osmotic effects (Wild, 1988).

Salt tolerance of a plant is defined as the ability to withstand the effects of high salinity without significant adverse effects such as growth or yield reduction or foliar salt damage (Grieve et al., 2008). This tolerance depends on species, plant growth stage, type of substrate or soil, climatic conditions irrigation management and irrigation method. With the aim to cope with the detrimental effects of salt stress, plants have evolved many biochemical and molecular mechanisms. Some of the biochemical strategies are selective build-up or exclusion of salt ions, control of ion uptake by roots and transport into leaves, ion compartmentalization, synthesis of compatible osmolytes, alteration in photosynthetic pathway, changes in membrane structure, induction of antioxidative enzymes and stimulation of phytohormones (Parida and Das, 2005).

Salinity measurements are important in irrigation management due to can be used in the prevention of salt build up in the substrate (van Iersel et al., 2013). Salts are quantified by measuring the electrical conductivity (EC). While growers habitually record average leachate EC values from various pots in an irrigation zone (the leachate is easy to collect), 
leachate EC records rarely coincide with those of pore water EC, because leachate EC depends on factors such as the leaching fraction, irrigation water salinity, the physical characteristics of the substrate and environmental conditions ( $\mathrm{Ku}$ and Hershey, 1991, Torres et al, 2010). There are two ways to measure EC in substrates from probe, measuring the pore water EC or bulk EC. Bulk EC is the combined electrical conductivity of the soil, air and water in a porous substrate. The main benefits of bulk EC are that can be measured continuously with an in situ probe and the values can be used in conjunction with volumetric water content to predict saturation extract EC or pore water EC. Pore water EC is the electrical conductivity of the solution contained in the soil pores. The values pore water EC are what the plant is actually experiencing and can be used to quantify how much salt is being transported by drainage water. The pore EC is calculated from bulk EC and volumetric water content measurements (estimation) or using in situ the pour-through method (real measurement). The pour-through extraction method has several advantages, as it samples the solution from the entire root zone and is non destructive. In fact, the only way to measure pore water EC is by extracting a soil water sample and measuring the EC of that sample. The major disadvantage of this method is that results are not monitoring. At the present, several models have been developed for converting bulk soil EC to solution (pore water) EC using the dielectric of the substrate (Rhoades et al., 1990; Hilhorst, 2000; Muñoz-Carpena et al., 2001; Regalado et al., 2007), this opens up new lines of research to control salinity in potted plant.

\section{Soil electrical conductivity and moisture sensors}

The measurement of the soil water volumetric content and bulk EC through dielectric methods are being used more frequently because they are non-destructive, easy to use, require little or no maintenance, provide instantaneous measurements and can provide continuous readings, they are non-radioactive, accurate measurements and their cost has decreased substantially in recent years (Cardenas-Lailhacar and Dukes, 2010; Kargas and Kerkides, 2012). An additional advantage of these sensors is that accurate measurements may be made in potted plant allowing rooted crops or plants grown.

The permittivity dielectric $(\varepsilon)$ of a medium is a complex number $\left(\varepsilon=\varepsilon^{\prime}-\mathrm{j} \varepsilon^{\prime \prime}\right)$ where the real part, $\varepsilon^{\prime}$, is related to the stored energy and the imaginary part, $\varepsilon^{\prime \prime}$, with total energy absorbed or lost by the material. The real component, $\varepsilon$ ' (also known as dielectric 
constant), provides an estimate of the water content of the soil, while the imaginary part $\varepsilon "$ depends on the soil bulk EC and the actual frequency the applied electric field (Ritter and Regalado, 2007). Estimation of water content using electromagnetic sensors is based on the ability of sensors to measure the real part of the dielectric permittivity $(\varepsilon)$, which directly relates to soil water volumetric content owing to the $\varepsilon$ contrast of soil constituents; $\varepsilon_{\mathrm{a}} \sim 1, \varepsilon_{\mathrm{s}} \sim 2-9$ and $\varepsilon_{\mathrm{w}} \sim 80$; where the subscripts a, s and $\mathrm{w}$ represent air, solids and water, respectively (Blonquist et al., 2006).

There are different types of dielectric sensors depending on the output signal used for estimating the volumetric water content based on time domain reflectometry (TDR), time domain transmissometry (TDT) and frequency domain reflectometry (FDR). Most of these instruments operate by sending an electromagnetic signal to a probe buried in the soil. The signal is then detected and analyzed. The time taken for the signal (TDT and TDR) or the frequency of the reflected wave (FDR) varies with the soil dielectric properties, which are mainly governed by the water content of the soil surrounding the probes (Topp, 2003; Blonquist et al., 2005). TDT and TDR sensors measure the permittivity of the soil by sending an electromagnetic signal along a waveguide and measuring the propagation time of that wave. FDR sensors also use an oscillator to propagate an electromagnetic signal through a metal tine or other wave guide, in this method is measured the difference between the output wave and the return wave frequency.

Currently, modern commercially available sensors systems include not only a sensor to be buried in the soil but also a controller to interface with the irrigation timer. The controller is a milestone in the development of the soil moisture sensor industry because it sends a signal to the buried sensor, and converts it to a "sensed" soil water content. At the same time, the controller acts as a switch that allows the operator to choose a desired soil water content threshold, above which scheduled irrigation events would not be allowed. This type of system adapts the amount of water applied according to plant requirements and actual weather conditions (Dukes, 2005; Pathan et al., 2003). Moreover, this helps to control leachate and preventing excessive leaching of nutrients. Hence, using data logger and soil moisture sensor to manage irrigation can increase profitability by saving irrigation water (van Iersel et al., 2009b; Belayneh et al., 2013).

In the same way, the availability of soil moisture sensors that are capable to measuring soil bulk EC has opened new possibilities for the control of irrigation and 
salinity (Incrocci el al., 2010). In potted crops, these sensors are of great relevance since that the volume of substrate available to the roots is small and the substrates have a tendency to retain a large amount of water and a low tension, promoting severe changes in substrate humidity of pot plants. In addition, under saline irrigation these sensors can play an important role in maintaining salinity thresholds (optimizing irrigation-drainage or facilitating irrigation waters of different salinity), in order to maintain the quality ornamental and minimize salt damage (Pardossi et al., 2009).

\section{Ornamental plant studied}

\section{Ficus benjamina}

Ficus benjamina L. is a member of the Moraceae family, native to South and Southeast Asia and Australia. F. benjamina is commonly known as the weeping fig, Benjamin's fig or ficus tree. It is one of the most widely grown indoor ornamental plant species and also as an ornamental tree or hedge. For many years, it has been an extremely popular houseplant in temperate areas, due to its aesthetic value and adaptability to the indoor environment (Veneklaas et al., 2002). Weeping fig tolerates poor growing conditions, such as a drought, salinity and strong winds. However, the leaves are very sensitive to small changes in light. When it is re-located it reacts by dropping many of its leaves and replacing them with new leaves adapted to the new light intensity.

Ficus benjamina is an evergreen shrub or tree to $20 \mathrm{~m}$ or more in natural conditions, with large arching branches and long pointed leaves. The leaves are shiny green oval with an acuminate tip. Trunk is pale brownish with dense foliage. Sometimes, the trunks are braided for ornamental interest. Stems have latex. This tree rarely flowers or fruits indoors. Weeping fig has an extensive roots system, it is characteristic of aerial roots that these descend from the branches. Roots can be a problem in landscape due to it grows rapidly invading gardens, growing under and lifting sidewalks, patios, roads and building foundation. There are numerous cultivars available for example 'Danielle', 'Naomi', 'Exotica', and 'Golden King'. Some cultivars include different patterns of colouration on the leaves, ranging from light green to dark green, and various forms of white or yellow variegation. 


\section{Pelargonium $x$ hortorum}

Geranium is one of the most widely grown ornamental plants in the world, for both pot culture and landscape use. There are approximately 280 species, native mostly to South Africa (Kellen, 1983). Currently, Europe and North America are the major producers and distributors of Pelargonium with global annual sales amounting of $\$ 700$ million (Mithila et al., 2001). The commercially important Pelargonium species have been categorized into four major groups: such as zonal geraniums (Pelargonium x hortorum), regal pelargonium (Pelargonium $\mathrm{x}$ domesticum), ivy geraniums (Pelargonium peltatum) and scented geraniums (Pelargonium sp.). Pelargonium breeding has developed into an industry of substantial commercial importance, part of which is derived from royalties paid to breeders of protected varieties, being zonal geranium the most economically important. In addition, there are scented geranium species serving as source of geranium essential oil and even as insect repellents (Amer and Mehlhorn, 2006), fungicides (Chandravadana and Nidiry, 1994; Lis Balchin et al., 1995) and nematicides (Chandravadana et al., 1996).

Pelargonium $\mathrm{x}$ hortorum L. H. Bailey, zonal geranium, belonging to the family Geraniaceae. Zonal geraniums are bushy plants with sizes $12-60 \mathrm{~cm}$ high to $30-38 \mathrm{~cm}$ width. It has a very long flowering season from spring to mid-winter; even they can bloom all year round. Its principal characteristic as a potted plant is the presence of a large number and scented flowers surrounded by thick green foliage. Geraniums have a woody base but the young shoots are soft and tender. Their roundish leaves have long stems and can be $2.5-10 \mathrm{~cm}$ in diameter. They have wavy edges and unequal lobes at the base. The leaves are "zoned" with a dark band halfway down the leaf blade and parallel to the leaf margin, which adds to the plants ornamental value. The whole plant is covered with soft fine fuzz. Flowers are normally five petals and in dense clusters (umbels) at the ends of strong, erect stalks (Nessmann, 1998). There are single, semi-double and double flowered kinds that come in a large range of colours such as red, purple, pink, orange, white and bicolours. Pelargonium $x$ hortorum has remained very popular with consumers for many years, mainly because of its large, showy flowers, insect resistance and drought tolerance (Lang and Trellinger, 2001). 


\section{Euphorbia pulcherrima}

The poinsettia, Euphorbia pulcherrima (Willd. ex Klotzch), is a native plant of Mexico and belonging to the family Euphorbiaceae (Ecke et al., 2004). The common name, poinsettia, honours the American Joel Roberts Poinsett, who introduced the plant into the United States in 1825 . The poinsettia is widely cultivated as a garden ornamental in tropical and subtropical areas and grown commercially as a potted plant, in particular for sale during the winter period. One of the top-selling potted flowering plants in the USA, poinsettias are the basis of a multi-million dollar Christmas industry.

Euphorbia pulcherrima is a shrubby perennial plant, typically reaching a height of 0.6 - 4 meters. The plant has dark green dentate leaves that measure 7 - 16 centimetres in length with long and slender petioles. Flowers of poinsettia are characterized by a single female flower without petals and usually without sepals, surrounded by individual male flowers all enclosed in a cup-shaped structure called a cyathium. On side of the cyathium, one to four or more yellow gland are borne (Larson, 1992), which secret a sweet honey. The green and yellow cyathia are in turn surrounded by a series of large bracts. The coloured bracts are most often red but can be orange, pale green, cream, pink, white, or marbled. The colours of the bracts are created through photoperiodism, meaning that they require darkness (12 hours at a time for at least five days in a row) to change colour. At the same time, the plants require abundant light during the day for the brightest colour. There are over 100 varieties of poinsettias available, there are in red, pink, white, yellow, purple, salmon, and multi-colours, although the red colour still dominates over other colour options. 'Prestige Red' one of many poinsettias patented by Ecke ranks among the best-selling hybrids.

\section{Osteospermum}

Vegetative osteospermum cultivars have great potential for flower plant production, because they produce many attractive flowers and can form a dramatic display of colour when planted in mass, blooming in early spring with a prolonged blooming time (Gibson and Whipker, 2003). This is why they have risen in popularity in the last fifteen years, becoming very popular as bedding plants, either in borders or in pots.

The genus Osteospermum belongs to the plant family Asteraceae. The plant originates from South Africa and is therefore also known under the common name 
'African Daisy'. There are two perennial-type plants, which vary by hardiness and an annual-type. The foliage is normally green in colour, although there are also some variegated forms. The leaf form varies and is sometimes a distinguishing feature between varieties. The four different leaf forms are lancet (typical for many of the hardy varieties), rounded and profiled, lancet and profiled and extremely profiled (or toothed). The flower heads have a central disc and petals in the shape of ray florets. The central disc comes in several colours, such as blue, yellow and purple. The colours of the petals vary from white, cream, pink, purple, mauve to yellow, they sometimes have a different shade at the tips, or towards the end of the petal. Some varieties have spoon shaped petals. The hardier varieties mostly have a distinct yellow disc, which is dark blue in the centre. Although there are many species of osteospermum, most of them in our gardens today are hybrids. The popularity of this plant ensures that the number of new varieties available each year is steadily growing.

\section{Gerbera hybrida}

Gerbera is one of the most important floricultural crops in worldwide. It has been commercially produced in Europe since the turn of the 20th century and in North America since the early 1920s. Continuous introduction of new cultivars with improved or novel horticultural characteristics has been one of the major driving forces for the popularity of this flower (Behnke, 1984; Rogers and Tjia, 1990). Gerbera is widely used as a decorative garden plant, cut flowers and potted plants (Rogers and Tjia, 1990). It is the fifth most used cut flower in the world (after rose, carnation, chrysanthemum, and tulip). For the past several decades, commercial breeding programs have focused efforts primarily on developing cultivars for cut flower production or for flowering pot plant production (Behnke, 1984; Rogers and Tjia, 1990). For cut flower cultivars are required to produce flowers with long peduncles (greater than $50 \mathrm{~cm}$ ), however, for pot gerbera cultivars are necessary compact foliage and flowers with short peduncles less than $25 \mathrm{~cm}$ (Dole and Wilkins, 1999). Recently, interest in producing gerberas in large containers (more than 3.8L) for indoor or outdoor use is increasing (Deng and Harbaugh, 2010).

Currently, the majority of the gerberas that are commercialized are hybrids of Gerbera jamesonii and G. viridifolia, both are is indigenous of South Africa and belonging to the family Asteraceae. Gerbera is commonly known as Barberton daisy and 
Transvaal daisy. Gerbera is herbaceous and perennial, which can produce flowers for several years. Leaves are elongated and can be entire or slightly lobed and form a rosette. Gerbera bears a large capitulum, two-lipped ray florets in yellow, orange, white, pink or red colours. The capitulum, which has the appearance of a single flower, is actually composed of hundreds of individual flowers. The morphology of the flowers varies depending on their position in the capitulum. Broadly, they can classify in four different groups. Single flowers, these have a row of non-overlapping petals (ray florets) with a green centre (disc florets) and these are the most common gerberas available in the market. Double or duplex, these have a double row of overlapping petals with a green, black, or dark red centre. Crested doubles, these doubles contain two rows of overlapping petals with one or more inner rows of shorter petals with a green, black, or dark red centre. Full crested doubles; these have solid overlapping rows of petals with an inner row diminishing in size, covering the centre entirely.

\section{References}

Amer, A., Mehlhorn, H., 2006. Larvicidal effects of various essential oils against Aedes, Anopheles, and Culex larvae (Diptera, Culicidae). Parasitol. Res. 99, 466-472.

Bacci, L., Battista, P., Rapi, B., 2008. An integrated method for irrigation scheduling of potted plants. Sci. Hort. 116, 89-97.

Bañón, S., Miralles, J., Franco, J.A., Ochoa, R., Sánchez-Blanco, M.J., 2011. Effects of diluted and pure treated wastewater on the growth, physiological status and visual quality of potted lantana and polygala plants. Sci. Hortic. 129, 869-876.

Behnke, M., 1984. Gerbera production. Grower Talks 47, 94-97.

Belayneh, B.E., Lea-Cox, J.D., Lichtenberg, E., 2013. Costs and benefits of implementing sensor-controlled irrigation in a commercial pot-in-pot container nursery. HortTechnology 23, 760-769.

Bilderback, T.E., 2002. Water management is key in reducing nutrient runoff from container nurseries. HortTechnology 12, 541-544.

Blonquist, J.M., Jones, S.B., Robinson, D.A., 2005. A time domain transmission sensor with TDR performance characteristics. J. Hydrol. 314, 235-245. 
Blonquist, J.M., Jones, S.B., Robinson, D.A., 2006. Precise irrigation scheduling for turfgrass using a subsurface electromagnetic soil moisture sensor. Agr. Water Manage. 84, 153-16.

Brar, M.S., Malhi, S.S., Singh, A.P., Arora, C.L., Gill, K.S., 2000. Sewage water irrigation effects on some potentially toxic trace elements in soil and potato plants in northwestern India. Can. J. Soil. Sci. 80, 465-471.

Burnett, S.E., van Iersel, M.W., 2008. Water use efficiency and morphology of Gaura lindhiemeri 'Siskiyou Pink' grown in capacitance sensor controlled irrigation. HortScience 43, 1555-1560.

Cabañero, F.J., Martínez, V., Carvajal, M., 2004. Does calcium determine water uptake under saline conditions in pepper plants, or is it water flux which determines calcium uptake? Plant Sci. 166, 443-450.

Cardenas-Lailhacar, B., Dukes, M.D., 2010. Precision soil moisture sensor irrigation controllers under field conditions. Agr. Water Manage. 97, 666-672.

Carter, C.T., Grieve, C.M., 2008. Mineral nutrition, growth, and germination of Antirrhinum majus L. (Snapdragon) when produced under increasingly saline conditions. HortScience 43, 710-718.

Carvajal, M., Martínez, V., Cerdá, A., 1999. Influence of magnesium and salinity on tomato plants grown in hydroponic culture. J. Plant Nutr. 22, 177-190.

Chandravadana, M.V., Nidiry, E.S.J., 1994. Antifungal activity of essential oil of Pelargonium graveolens and its constituents against Colletotrichum gloeosporioides. Indian J. Exp. Biol. 32, 908-909.

Chandravadana, M.V., Sebastian, E., Nidiry, J., Lella, N.K., Reddy, P.P., Khan, R.M., Rao, M.S., 1996. Nematicidal activity of some plant extracts. Indian J. Nematol. 26, 148-151.

Deng, Z., Harbaugh, B. K., 2010. UFGE 4141, UFGE 7014, UFGE 7015, UFGE 7023, UFGE 7032, and UFGE 7034: Six new gerbera cultivars for marketing flowering plants in large containers. HortScience 45, 971-974.

Dole, J.M.,Wilkins, H.F., 1999. Gerbera. In: Dole and Wilkins (ed.) Floriculture, principles and species. Prentice Hall, Upper Saddle River, NJ.

Dukes, M. D., 2005. Residential irrigation water use and control. Encyclopedia of water science.Marcel Dekker, New York, NY. DOI: 10.1081/E-EWS-120041736.

Ecke, P., Williams, J., Faust, J.E., Higgins, A., 2004. The Ecke Poinsettia Manual. Ball Publishing. Batavia, Illinois, USA, pp. 287. 
Fare, D., Gilliam, C.H., Keever, G.J., 1992. Monitoring irrigation at container nurseries. HortTechnology 2, 75-78.

Feigin, A., Ravina, I., Shalhevet, J., 1991. Irrigation with Treated Sewage Effluent: Management for Environmental Protection. Springer-Verlag, Berlin,p. 224.

Fulcher, A. F., Buxton, J. W., Geneve, R. L., 2012. Developing a physiological-based, ondemand irrigation system for container production. Sci. Hortic. 138, 221-226.

Fulcher, A., Fernandez, T., 2013a. Sustainable nursery irrigation management, Part I. Water use in nursery production. University of Tennessee W278 https://utextension.tennessee.edu/publications/Documents/W278.pdf

Fulcher, A., Fernandez, T., 2013b. Sustainable nursery irrigation management, Part II. Strategies to increase nursery crop irrigation efficiency. University of Tennessee W279. https://utextension.tennessee.edu/publications/Documents/W279.pdf

Garcia-Navarro, M.C., Evans, R.Y., Montserrat, R.S., 2011. Estimation of relative water use among ornamental landscape species. Sci. Hortic. 99, 163-174.

Gibson, J.L., Whipker, B.E., 2003. Efficacy of Plant Growth Regulators on the Growth of Vigorous Osteospermum Cultivars. HortTechnology 13, 132-135.

Grant, O.M., Davies, M.J., Longbottom, H., Atkinson, C.J., 2009. Irrigation scheduling and irrigation systems: optimizing irrigation efficiency for container ornamental shrubs. Irrig. Sci. 27, 139-153.

Grieve, C., Wu, L., Rollins, L., Harivandi, A., 2008. Tolerance by landscape plants of salinity and of specific ions (Chapter V). In: A comprehensive literature review on salt management guide for landscape irrigation with recycled water in coastal southern California, Dec. 2009.http://www.salinitymanagement.org.

Hagen, E. D., 2013. Use of capacitance sensors for development of conservative irrigation regimes. Master's Thesis, University of Tennessee. http://trace.tennessee.edu/utk_gradthes/2420

Hilhorst, M.A., 2000. A pore water conductivity sensor. Soil Sci. Soc. Am. J. 64, 19221925.

Incrocci, L., Marzialetti, P., Incrocci, G., Balendonck, J., Spagnol, S., Pardossi, A., 2010. Application of WET Sensor for Management of Reclaimed Wastewater Irrigation in Container-Grown Ornamentals (Prunus laurocerasus L.). Transactions of the Third International Symposium on Soil Water Measurement Using Capacitance, Impedance and TDT, Murcia, Spain, 7-9 April 2010. 
Jones, H.G., 2008. Irrigation scheduling - Comparison of soil, plant and atmosphere monitoring approaches. Acta Hort. 792, 391-403.

Kargas, G., Kerkides, P., 2012. Comparison of two models in predicting pore water electrical conductivity in different porous media. Geoderma 189, 563-573.

Kellen, V., 1983. Pelargonium $x$ hortorum or a geranium by any other name. Florists' Review. 173, 19-24.

Lang, H., Trellinger, K., 2001. Geraniums. In: Gaston, M., Konjoian, P., Kunkle, L., Wilt, M., (eds) Tips on regulating growth of floriculture crops. Ohio Florists' Associations Services Inc, Columbus, pp 88-95.

Larson, R.A., 1992. Introduction to Floriculture. 2 Ed. Academic Press London, 306-307.

Lea-Cox, J.D., 2012. Using wireless sensor networks for precision irrigation scheduling. Problems, perspectives and challenges of agricultural water management. InTech Press, Rijeka, Croatia, 233-258.

Lis Balchin, M., Hart, S.L., Deans, S.G., Eaglesham, E., 1995. Potential agrochemical and medicinal usage of essential oils of Pelargonium species. J. Herbs. Spices. Med. Plants 3, 11-22.

Million, J. B., Yeager, T. H., Albano, J. P., 2010. Evapotranspiration-based Irrigation Scheduling for Container-grown Viburnum odoratissimum (L.) Ker Gawl. HortScience 45, 1741-1746.

Mathers, H.M., Yeager, T.H., Case. L.T., 2005. Improving irrigation water use in container nurseries. HortTechnology 15, 8-12.

Miralles, J., van Iersel, M., 2011. A calibrated time domain transmissiometry soil moisture sensor can be used for precise automated irrigation of containergrown plants. HortScience 46, 889-894.

Mithila, J., Murch, S.J., KrishnaRaj, S., Saxena, P.K., 2001. Recent advances in Pelargonium in vitro regeneration systems. Plant Cell. Tiss. Org. 67, 1-9.

Miyamoto, S., Chacon, A. Hossain, M., Martinez, I., 2005. Soil salinity of urban turf areas irrigated with saline water. I. Spatial variability. Landsc. Urban Plan. 71, 233-241.

Morales, M.A., Olmos, E., Torrecillas, A., Sánchez-Blanco, M.J., Alarcón, J.J., 2001. Differences in water relations, leaf ion accumulation and excretion rates between cultivated and wild species of Limonium sp. grown in conditions of saline stress. Flora 196, 345-352.

Muñoz-Carpena, R., Regalado, C.M., Alvarez-Benedí, J., Socorro, A.R., Pérez, N., 2001. Determinación simultánea mediante TDR del transporte de agua y un soluto salino en 
el suelo, p.1-7. In: López, J. J., Quemada, M. (eds.). Temas de investigación en zona no saturada. Universidad Pública de Navarra, Pamplona, p. 1-7.

Navarro, J.M., Garrido, C., Martínez, V., Carvajal, M., 2003. Water relations and xylem transport of nutrients in pepper plants grown under two different salts stress regimes. Plant Growth Regul. 41, 237-245.

Nessmann, P., 1998. Los geranios. Jardinería práctica. Susaeta ediciones S.A., Madrid. 69 pp.

Niu, G., Rodriguez, D.S., 2006a. Relative salt tolerance of five herbaceous perennials. HortScience 41, 1493-1497.

Niu, G., Rodriguez, D.S., 2006b. Relative salt tolerance of selected herbaceous perennials and groundcovers. Sci. Hort. 110, 352-358.

Niu, G., Cabrera, R.I., 2010. Growth and physiological responses of landscape plants to saline water irrigation - a review. HortScience 45, 605-1609.

Niu, G., Rodriguez, D.S., Starman, T., 2010. Response of bedding plants to saline water irrigation. Hortscience 45, 628-636.

Pardossi, A., Incrocci L., Incrocci, G., Malorgio, F., Battista, P., Bacci, L., Rapi, B., Marzialetti, P., Hemming, J., Balendonck, J., 2009. Root zone sensors for irrigation management in intensive agriculture. Sensors 9, 2809-2835. [http://www.mdpi.com/1424-8220/9/4/2809/pdf ].

Parida, A.K., Das, A.B., 2005. Salt tolerance and salinity effects on plants: a review. Ecotox. Environ. Safe 60, 324-349.

Pathan, S.M., Barton, L., Colmer, T.D., 2003. Evaluation of a soil moisture sensor to reduce water and nutrient leaching in turf. Horticulture Australia Project number TU 02006. 21p.

Reed, D.W., 1996. Closed production systems for containerized crops. Water, media and nutrition for greenhouse crops. Ball Publishing, Inc., Batavia, IL, 221-245.

Regalado, C.M., Ritter, A., Rosa M., Rodríguez-González, R.M., 2007. Performance of the Commercial WET Capacitance Sensor as Compared with Time Domain Reflectometry in Volcanic Soils. Vadose Zone J. 6, 244-254.

Ritter, A., Regalado, C.M. 2007. Eficacia de un sensor de capacitancia para medir simultáneamente salinidad y contenido hídrico. En: J.V. Giráldez Cervera y F.J. Jiménez Hornero, pp 145-151. Estudios de la Zona No Saturada del Suelo Vol. VIII, Instituto Canario Inv. Agrarias (ICIA). 
Rhoades, J.D., Shouse, P.J., Alves, W.J., Manteghi, N.A., Lesch, S.M., 1990. Determining Soil Salinity from Soil Electrical Conductivity using Different Models and Estimates. Soil Sci. Soc. Am. J. 54, 46-54.

Rogers, M.N., Tjia, B.O., 1990. Gerbera production for cut flowers and pot plants. Timber Press, Portland, Ore.

Shannon, M.C., Grieve, C.M., 1999. Tolerance of vegetable crops to salinity. Sci. Hort. 78, 5-38.

Skimina, C.A., 1992. Recycling water, nutrient sand waste in the nursery industry. HortScience 27, 968-971.

Sonneveldt, C., 1988. The salt tolerance of greenhouse crops. Neth. J. Agric. Sci. 36, 6373.

Tester, M., Davenport, R., 2003. $\mathrm{Na}^{+}$tolerance and $\mathrm{Na}^{+}$transport in higher plants. Ann. Bot. 91, 503-527.

Topp, G.C., 2003. State of the art of measuring soil water content. Hydrol. Process. 17, 2993-2996.

Turral, H., Burke, J., Faurès, J. M., 2011. Climate change, water, and food security. Water Reports, No. 36. Food and Agriculture Organization of the United Nations, Rome. http://www.fao.org/docrep/014/i2096e/i2096e.pdf.

van Iersel, M., Dove, S., Burnett, S., 2009a. The use of soil moisture probes for improved uniformity and irrigation control in greenhouses. International Symposium on High Technology for Greenhouse Systems: GreenSys 89, 1049-1056.

van Iersel, M.W., Seymour, R.M., Chappell, M., Watson, F., Dove. S.K., 2009b. Soil moisture sensor-based irrigation reduces water use and nutrient leaching in a commercial nursery. Proc. Southern Nursery Assn. Res. Conf. 54, 17-21.

van Iersel, M.W., Chappell, M., Lea-Cox, J.D., 2013. Sensors for improved efficiency of irrigation in greenhouse and nursery production. HortTechnology 23, 735-746.

Veneklaas, E.J., Santos Silva, M.P.R.M., Den Ouden, F., 2002. Determinants of growth rate in Ficus benjamina L. compared to related faster-growing woody and herbaceous species. Sci. Hort. 93, 75-84.

Warren, S., Bilderback, W., 2005. More plants per gallon: getting more out of water. HortTechnology 15, 14-18.

Warsaw, A.L., Fernandez, R.T., Cregg, B.M., Andresen, J.A., 2009. Water conservation, growth, and water use efficiency of container-grown woody ornamentals irrigated based on daily water use. HortScience 44, 1308-1318. 
Wild, A., 1988. Russell's Soil Conditions and Plant Growth, 11th ed. Longman, Harlow.

Yadav, R.K., Goyal, B., Sharma, R.K., Dubey, S.K., Minhas, P.S., 2002. Postirrigation impact of domestic sewage effluent on composition of soils, crops and ground water-a case study. Environ Int. 28, 481-486. 


\section{Chapter 1}

\section{Saline reclaimed wastewater can be used to produce potted weeping fig (Ficus benjamina L.) with minimal effects on plant quality}

R. Valdés ${ }^{1}$, J. Miralles ${ }^{1}$, J. Ochoa $^{1}$, M. J. Sánchez-Blanco ${ }^{2,3}$ and S. Bañón ${ }^{1,2}$

${ }^{1}$ Departamento de Producción Vegetal. Universidad Politécnica de Cartagena. Cartagena, Spain

${ }^{2}$ Unidad Asociada de Horticultura Sostenible en Zonas Áridas, CEBAS-Universidad Politécnica de Cartagena, Cartagena-Murcia, Spain

${ }^{3}$ Centro de Edafología y Biología Aplicada del Segura-CSIC, Murcia, Spain

Article reference:

Valdés, R., Miralles, J., Ochoa, J., Sánchez-Blanco, M.J., Bañón, S., 2012. Saline reclaimed wastewater can be used to produce potted weeping fig (Ficus benjamina L.) with minimal effects on plant quality. Span. J. Agric. Res. 10, 1167-1175.

Year 2012:

Impact factor: 0.659

Category: Agriculture, Multidisciplinary

Category ranking 2012: (28/57)

Quartile in category: Q2 


\begin{abstract}
The objective of the present study was to investigate the limitations of irrigation with saline reclaimed wastewater (RW) for producing potted weeping fig (Ficus benjamina L.). Furthermore, two different levels of leaching were studied to ascertain whether either reduces the negative effects of RW. The study was conducted in Cartagena, Spain $\left(37^{\circ} 35^{\prime} \mathrm{N}, 0^{\circ} 59^{\prime} \mathrm{W}\right)$. Three irrigation treatments were applied: a) well water (control), b) RW (5 dS m${ }^{-1}$ ) with a constant leaching fraction of $23 \%$ (RWL), and c) RW $\left(5 \mathrm{dS} \mathrm{m}^{-1}\right)$ with a constant leaching fraction of $15 \%$ and $50 \%$ flushing every nine irrigation events (RWF). After five months of exposure to the RW, plant size, leaf area, specific leaf area, plant DW, stem diameter and shoot/root ratio were reduced, but both compactness and the appearance of the plants remained high. RWF reduced leaf area, plant dry weight, stem diameter, leaf lightness, leaf chroma and leaf SPAD compared with the RWL. Water consumption per pot was higher in control (50.58 L), followed by RWL (24.29 L) and RWF (19.6 L). Photosynthesis and stomatal conductance were 50\% lower in RWL plants than in the control, while the RWF plants had the lowest rates. RWF caused damages in the photochemical apparatus. This study confirms that: a) weeping fig is a good candidate for being grown with saline RW without compromising its aesthetic value; b) RW may be regarded as a good alternative to the retardants used in this plant; and c) the recommended irrigation would be RWL.
\end{abstract}

Keywords: irrigation, ornamental plant, pot plant, salinity

\title{
1. Introduction
}

A possible supplementary or alternative source of irrigation water for nursery production and landscaping is reclaimed wastewater, especially in arid and semiarid regions of the world. However, a potential problem with reclaimed wastewater is its high salt content, which is detrimental to sensitive plants if not managed properly (Niu and Cabrera, 2010). The high salinity of irrigation water may adversely affect the growth and appearance of ornamental plants, causing leaf damage, such as burning or chlorosis, with a consequent loss of plant quality. Salinity may also disrupt physiological functions, reducing growth. However, salinity may also be a tool for controlling plant quality and development. 
Selecting crops that can tolerate a degree of salinity stress is fundamental for putting saline water to its best use. Weeping fig (Ficus benjamina L.) is an important component in foliage plant production, being used extensively as potted house plant. Many studies on this specie have been focused on rooting, in vitro culture, indoor acclimatization, environmental effects, nutrition, plant retardants, etc., while the information available concerning saline stress is scarce. Black (2003) considered weeping fig as a moderately salt-tolerant plant, and Vogelezang (1991) found it tolerated high electric conductivity (EC) levels.

Salt tolerance must also be considered in the light of irrigation management. Oron et al. (2002) reported that highly saline water has an agricultural potential in combination with proper leaching and irrigation management. Several studies have indicated that when saline water is used for irrigation, due attention should be given to minimizing root zone salinity (Katerji et al., 2004). The accumulation of salts in the root zone can only be prevented by leaching with extra irrigation water. Different recommendations on leaching fraction have been made considering irrigation water EC and leachate EC, but less is known about combinations of leaching and flushing to reduce salt damage.

The objective of the experiment was twofold: (i) to study the growth, visual quality and physiological responses of weeping fig to saline reclaimed wastewater; and (ii) to assess two strategies of irrigation and drain-off to reduce salinity damage in ficus.

\section{Materials and methods}

Three seedlings of one year old weeping fig (cv. Danielle) were transplanted to brown PVC $2.5 \mathrm{~L}$ pots (16 $\mathrm{cm}$ upper internal diameter), containing a mixture of black peat, coconut fiber and perlite as substrate (2:2:1 vol.). The transplantation of seedlings to cultivation pots was carried out in the last week of February 2011, and the experiment finished in the last week of July 2011. The study was conducted in a greenhouse at the Agricultural Experimental Station of the Polytechnic University of Cartagena $\left(37^{\circ} 35^{\prime} \mathrm{N}\right.$, $0^{\circ} 59^{\prime} \mathrm{W}$ ), using nine metal crop tables ( $3 \mathrm{~m}$ long, $1.30 \mathrm{~m}$ wide and $0.80 \mathrm{~m}$ high). Twentyfour pots were placed on each of the tables 24 pots arranged in three rows of 8 pots.

The experiment comprised three irrigation treatments: a) control [water taken from a canal that delivers water $\left(1 \mathrm{dS} \mathrm{m} \mathrm{m}^{-1}\right)$ from the Tagus River to the Segura River for agricultural and municipal use] with a constant leaching fraction of about 15\%; b) saline 
reclaimed wastewater $\left(5 \mathrm{dS} \mathrm{m}^{-1}\right)$ with a constant leaching fraction of about $23 \%$ (RWL); and c) saline reclaimed wastewater with a constant leaching fraction of about $15 \%$ and flushing of about $50 \%$ every nine irrigation events (RWF).

The irrigation was controlled by a system similar to that described by Nemali and van Iersel (2006) but with a CR1000 data logger, balances (Analytical Sartorius, Model 5201, capacity $5.2 \mathrm{~kg}$ and readability of $0.01 \mathrm{~g}$ ) and an Agrónic 4000 (Sistemes Electrònics PROGRÉS, S. A., Bellpuig, Spain) to control three pumps connected to three $1000 \mathrm{~L}$ tanks which contained the different irrigation solutions. Each pot had one emitter $\left(2 \mathrm{~L} \mathrm{~h}^{-1}\right)$ connected to a spaghetti tube. The pressure-compensated drip emitters used were tested for homogeneity before the experiment started (the water flow varied between 1.9 and $2.1 \mathrm{~L} \mathrm{~h}^{-1}$ ). The CR1000 recorded the weight of the pots every ten minutes. Three balances were installed per treatment and, on each balance, a PVC tray slightly inclined to one side and with drainage holes ensured that the leachate could be collected. The datalogger was programmed to record the weight of the pots thirty minutes after each irrigation event (mean of three pots), and the following irrigation event was triggered when pots had lost $250 \mathrm{~g}$ (Picture 1). We programmed the CR1000 to count every irrigation event and flushing automatically. The leaching fraction was adjusted with the irrigation time.

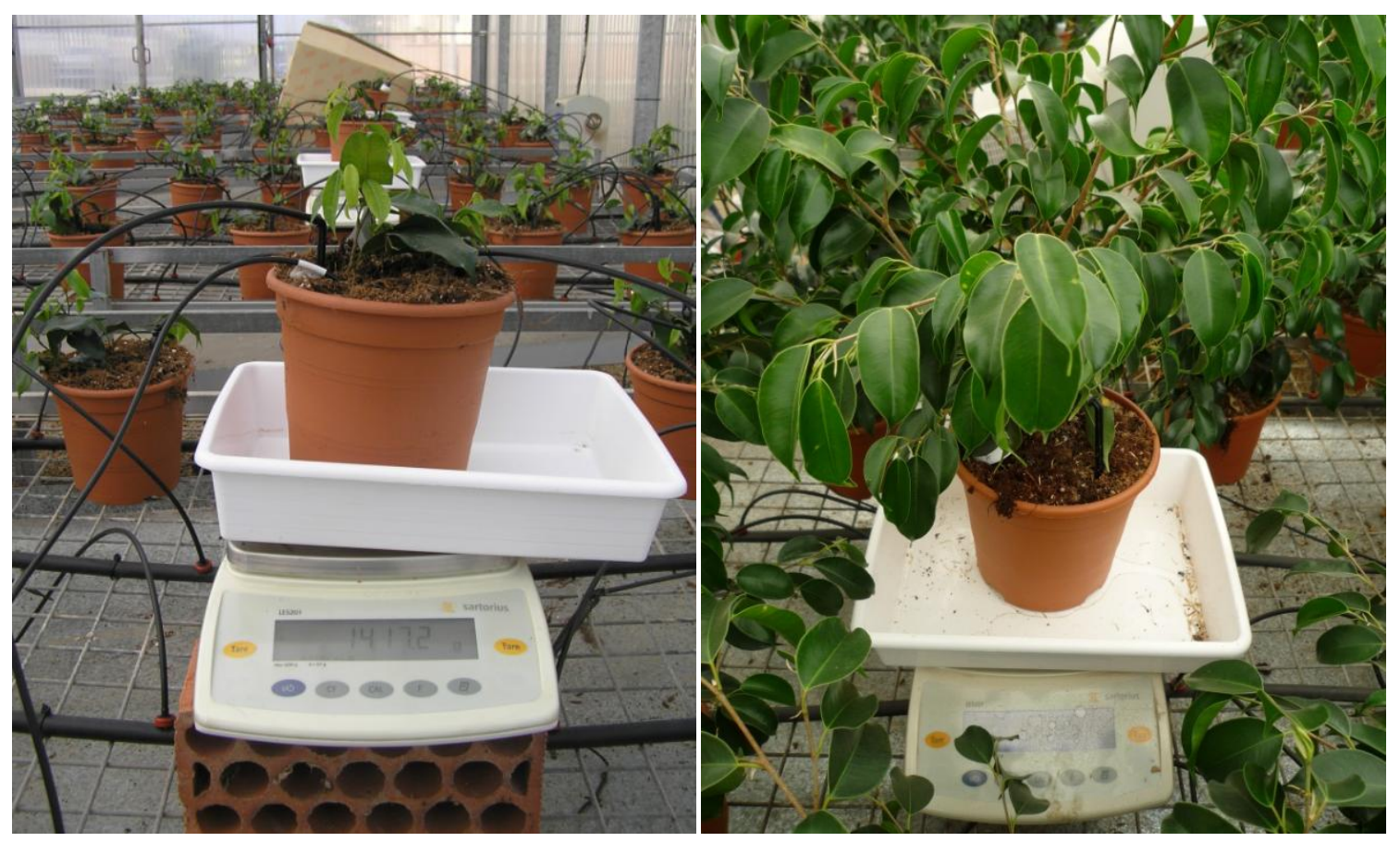

Picture 1. Detail of system irrigation with programmable balance at the beginning and at the end of the cultivation cycle. 
Fertilization was carried out by the irrigation head, and nutrients were provided at constant concentrations in the irrigation water, containing $80 \mathrm{~N}-40 \mathrm{P}_{2} \mathrm{O}_{5}-80 \mathrm{~K}_{2} \mathrm{O}(\mathrm{ppm})$ and a $\mathrm{pH}$ 6. This nutrient solution was made by mixing $\mathrm{KNO}_{3}, \mathrm{NH}_{4}\left(\mathrm{NO}_{3}\right), \mathrm{K}\left(\mathrm{HPO}_{4}\right)$ and nitric acid $\left(\mathrm{HNO}_{3}\right)$. The fertilizers added increased EC by approximately 0.39 and $0.36 \mathrm{dS}$ $\mathrm{m}^{-1}$ in control water and RW, respectively. The reclaimed wastewater was refined by a tertiary treatment plant (Los Alcazares, Murcia), and contained the following ion concentrations in $\mathrm{mg} \mathrm{L}^{-1}: \mathrm{Na}^{+}$(683.69), $\mathrm{K}^{+}$(24.57), $\mathrm{Ca}^{2+}$ (180), $\mathrm{Mg}^{2+}$ (137.98), chloride (1083.03), sulfate (969.38), carbonates $(<5)$, bicarbonate (297.00), nitrates (6.39), ammonia (1.15), phosphate (1.44), boron (1.23), manganese (28.78), iron (52.40), zinc $(<0.04)$, copper $(<0.04)$. It had a pH of 7.09 and an EC of $4.99 \mathrm{dS} \mathrm{m}^{-1}$.

A datalogger (HOBO H08-004-02, MicroDAQ.com, Ltd., Contoocook, NH) was used to measure air temperature and humidity with a Temperature/RH Smart Sensor STHB-M008 (MicroDAQ.com, Ltd., Contoocook, NH), and photosynthetic active radiation with a HOBO sensor S-LIA-M003 Smart Sensor (MicroDAQ.com, Ltd., Contoocook, $\mathrm{NH})$. Data were collected at 60 second intervals and averages were recorded every thirty minutes. Weather conditions were $15.7 \pm 4.6{ }^{\circ} \mathrm{C}$ (minimum) and $33.3 \pm 5.3{ }^{\circ} \mathrm{C}$ (maximum); minimum relative humidity was $38 \pm 11 \%$ and the maximum $82 \pm 4 \%$. The daily light integral (DLI) was calculated by integrating the photosynthetic photon flux measurements throughout the day, giving $13.9 \pm 4.6 \mathrm{~mol} \mathrm{~m}^{-2} \mathrm{~s}^{-1}$ (mean \pm s.d.) over the 150 days of the experiment.

At the end of the experiment, the dry weight (DW) of roots, stems and leaves was determined in six plants per treatment, gently washing the substrate from the roots with pressurized water using a hose with flat tip. To calculate the DW, leaves, stems and roots were introduced in clearly identified envelopes and placed in a natural convection bacteriological stove (model 2002471, JP Selecta SA, Barcelona, Spain) at $60{ }^{\circ} \mathrm{C}$ until constant weight was reached. Finally, the DW was determined by weighing with a GRAM ST precision balance (sensitivity of $10 \mathrm{mg}$ and up to $1200 \mathrm{~g}$, Gram Precision SL, Barcelona, Spain). The leaf area was determined with a LI-3100C (LI-COR Biosciences, Lincoln, NE) in the same plants whose DW was measured. The blade area was calculated by dividing the leaf area by the number of leaves. The growth indices determined were the shoot DW/root DW (S/R) and the specific leaf area (SLA) (leaf area/leaf DW). The plant architecture was determined in six plants per treatment. The compactness index was determined with a photograph taken with an HP CW450 digital camera (Hewlett-Packard 
Española S.L.) and the formula, compactness index=plant profile area/[( $\pi / 4) \mathrm{x}(($ height + width)/2)exp2], where the plant profile area is the area within the plant perimeter. The plant area, and the height and width of the plant, were obtained from the picture using the software UTHSCSA Image Tool (University of Texas, San Antonio, TX). Two indexes were calculated for the side and top image, and the average of both is given as the final index of compactness. The closer the result was to unity, the more compact were the plants. Six plants were used. The base stem diameter was determined with an electronic SYLVAC gauging device (sensitivity of $0.01 \mathrm{~mm}$ and maximum $150 \mathrm{~mm}$, TECMICRO SA, Madrid, Spain).

The leachate was collected weekly in plastic containers and measured gravimetrically. Leachate EC was analyzed immediately after collection using an EC meter (Dist ${ }^{\circledR}$ 6, Hanna Instruments S.L., Eibar, Spain). We represented an average of all the experiment both leachate and leachate EC. The LF was quantified as the volume of solution leached from the pot divided by the total solution applied. Substrate pore water EC was measured in six replicates per treatment following the pour-through method (Wright, 1986) at the end of the experiment. The water use efficiency (WUE) was calculated as the total DW harvested divided by the water applied (determined by the CR1000).

Leaf color and SPAD measurements were made in six plants of each treatment (four per repetition) at the end of the experiment, selecting representative south-facing, midheight mature plant leaves. The color was determined with a shot in the middle of the leaf blade with a Minolta CR10 colorimeter (Konica Minolta Sensing, Inc., Osaka, Japan) that calculated the color coordinates (CIELAB): lightness, hue angle and chroma. The SPAD was measured using the same criteria as for color but with a SPAD-502 chlorophyll meter (Konica Minolta Sensing, Inc., Osaka, Japan) which estimates relative chlorophyll content with the light transmitted through the leaf at $650 \mathrm{~nm}$ (photosynthetically active wave length) and $940 \mathrm{~nm}$. For each measurement the average of three shots was determined.

Leaf and root dry matter samples were used to determine chlorides and sodium. Dry tissue samples were ground and three sub-samples of $0.2 \mathrm{~g}$ were analysed after extraction in $50 \mathrm{ml}$ of distilled water by ion chromatography (ion chromatography system, model 861, Metrohm AG, Herisau, Switzerland) equipped with conductometric detector and an autosampler (Metrohm 838 Advanced Sample Processor), consisting of an anion separator column Metrosep A Supp 5-250 $(250 \mathrm{~mm} \times 4.0 \mathrm{~mm}, 5 \mu \mathrm{m}$ particle size $)$ with a pre-guard 
column (Metrosep A Supp 4/5 Guard $5 \mathrm{~mm} \times 4 \mathrm{~mm}$ ), and a cation separator column Metrosep C 2-250 (250 $\mathrm{mm} \times 4.0 \mathrm{~mm}, 7 \mu \mathrm{m}$ particle size) with a pre-guard column (Metrosep C 2, $5 \mathrm{~mm} \times 4 \mathrm{~mm}$ ). The suppressors used were MSM II (Metrohm Suppressor Module) for anions. In all cases, mature leaves were taken from the middle of the plant. Six plants per treatment for each species were used for experimental purposes.

Leaf water potential $\left(\Psi_{1}\right)$, leaf osmotic potential $\left(\Psi_{\mathrm{o}}\right)$ and leaf pressure potential $\left(\Psi_{\mathrm{p}}\right)$ were determined. $\Psi_{1}$ was estimated using a Scholander pressure chamber (Soil Moisture Equipment Co, Santa Barbara, CA, USA), for which leaves were enclosed in a plastic bag and sealed in the chamber within $20 \mathrm{~s}$ of collection and pressurised at a rate of $0.02 \mathrm{MPa} \mathrm{s}^{-}$ ${ }^{1}$. Leaves from the $\Psi_{1}$ measurements were frozen in liquid nitrogen $\left(-170{ }^{\circ} \mathrm{C}\right)$ and stored at $-30^{\circ} \mathrm{C}$. After thawing, the sap was extracted from the sample with a small press, and then placed on a filter paper disc in the osmometer chamber and the values of the $\Psi_{0}$ were measured using a WESCOR 5520 vapour pressure Osmometer (Wescor Inc., Logan, UT, USA). $\Psi_{\mathrm{p}}$ was estimated as the difference between $\Psi_{1}$ and $\Psi_{\mathrm{o}}$ for each time. All measurements were taken at midday in six plants per treatment at the end of the experiment.

Stomatal conductance $\left(g_{\mathrm{s}}\right)$ and the net photosynthesis rate at midday $\left(P_{\mathrm{n}}\right)$ were measured at midday using a CIRAS-2 Portable Photosynthesis System (PP Systems, Amesbury, MA). The air flow rate through the cuvette was $200 \mathrm{~mL} \mathrm{~min}^{-1}$ with a $\left[\mathrm{CO}_{2}\right]$ of $420 \mu \mathrm{mol} \mathrm{mol}{ }^{-1}$, an air temperature of $20{ }^{\circ} \mathrm{C}$, a vapour pressure deficit of $1.6 \mathrm{kPa}$, and a photosynthetic photon flux of $1000 \mu \mathrm{mol} \mathrm{m} \mathrm{m}^{-2}$. The chlorophyll fluorescence was measured using a Pulse Modulated Fluorimeter FMS-2 (Gomensoro Scientific Instrumentation, S.A., Madrid, Spain). The method and parameters determined were those described by Miralles et al. (2011). All measurements were performed in the same leaves at the end of the experiment: six plants per species and three leaves per plant in each treatment.

The design was a randomized complete block design. There were three blocks of 24 plants per treatment set on a crop table. Treatments were analysed by one-way analysis of variance using Statgraphics Plus for Windows. Treatment means were separated by LSD Test $(p<0.05)$. Regression analyses were also determined between DLI and daily ET, and between days of culture and daily ET. Ratios and percentages were arcsine $(x)^{1 / 2}$ transformed before statistical analysis to ensure homogeneity of variance. 


\section{Results and discussion}

The RW treatments reduced plant height and width by $36 \%$ and $13 \%$, respectively, compared with the control, which led to a smaller plant size (Table 1 and Picture 2). In calceolaria, Fornes et al. (2007) indicated that a strong reduction in size was the main factor protecting plants from saline stress. Niu and Cabrera (2010) suggests that all parts of a plant, including leaves, stems and roots, may be reduced in size under saline conditions. We measured the blade area size, determining that the plants irrigated with RW presented smaller leaves than the control plants as well as the number of leaves (by around 60\%). Both foliar reductions led to strong decrease in leaf area in RWL (about $63 \%$ ) and RWF (about 74\%). Specific leaf area (SLA) decreased under RW too, indicating that the leaves become thicker and/or more succulent. Small plant size together with changes in leaf morphology leading to a fall in water extraction from the soil has been proposed as an important mechanism for drought tolerance (Kusaka et al., 2005). Otherwise, a decreased SLA in salinized plants could mean greater amounts of photosynthetic apparatus per leaf area than in non-salinized plants, which could represent an effective water stress resistance mechanism because it would allow photosynthesis to increase (Zwack and Graves, 1998). However, in this experiment this did not occur because the RW irrigated plants were seen to suffer a sharp fall in $P_{\mathrm{n}}$.

The treatments with RW reduced the control plant DW by 53\% (RWL) and 67\% (RWF), which were accompanied by a reduction in stem diameter. RWF caused a greater reduction in plant DW and stem diameter than RWL (Table 1). Salt tolerance is usually assessed as the percentage of biomass production in saline versus control conditions over a prolonged period of time (Munns et al., 2002). From this point of view we should classify weeping fig as a salinity-sensitive plant. Results for shoot/root ratio showed reduction under the treatments with RW, meaning that the shoot growth was more sensitive to RW than root growth. Usually, growth reduction by salinity in shoots is greater than in roots (Munns et al., 2002), and ficus is not an exception in this respect. A low shoot/root ratio means that roots are abundant with regard to leaf area, and that the plant has a high water stress avoidance potential (Miralles et al., 2009).

As noted above, RWF reduced plant DW, stem diameter and leaf area compared with the RWL, which suggests that the plants under RWF were subjected to more stressful saline conditions than those under RWL. However, RWF and RWL had similar pore water EC, which does not support these results, suggesting that the final measurement of pore 
water EC did not provide accurate information on the saline stress level in plants during the cultivation period. Leachate EC was highest after each flushing event in RWF (data not shown), although the average leachate EC during the experiment was the same for RWL and RWF (Table 1). This can be explained by the tendency of water in drip irrigation to flow downwards rather than to spread horizontally (De Rijck and Schrevens, 1998). In this way, salt accumulated around the wet bulb produced by the dripper and the flushing washed out some of these salts. Therefore, root sphere EC in RWF was less stable than in RWL during the experiment, leading to worse saline conditions in the former.

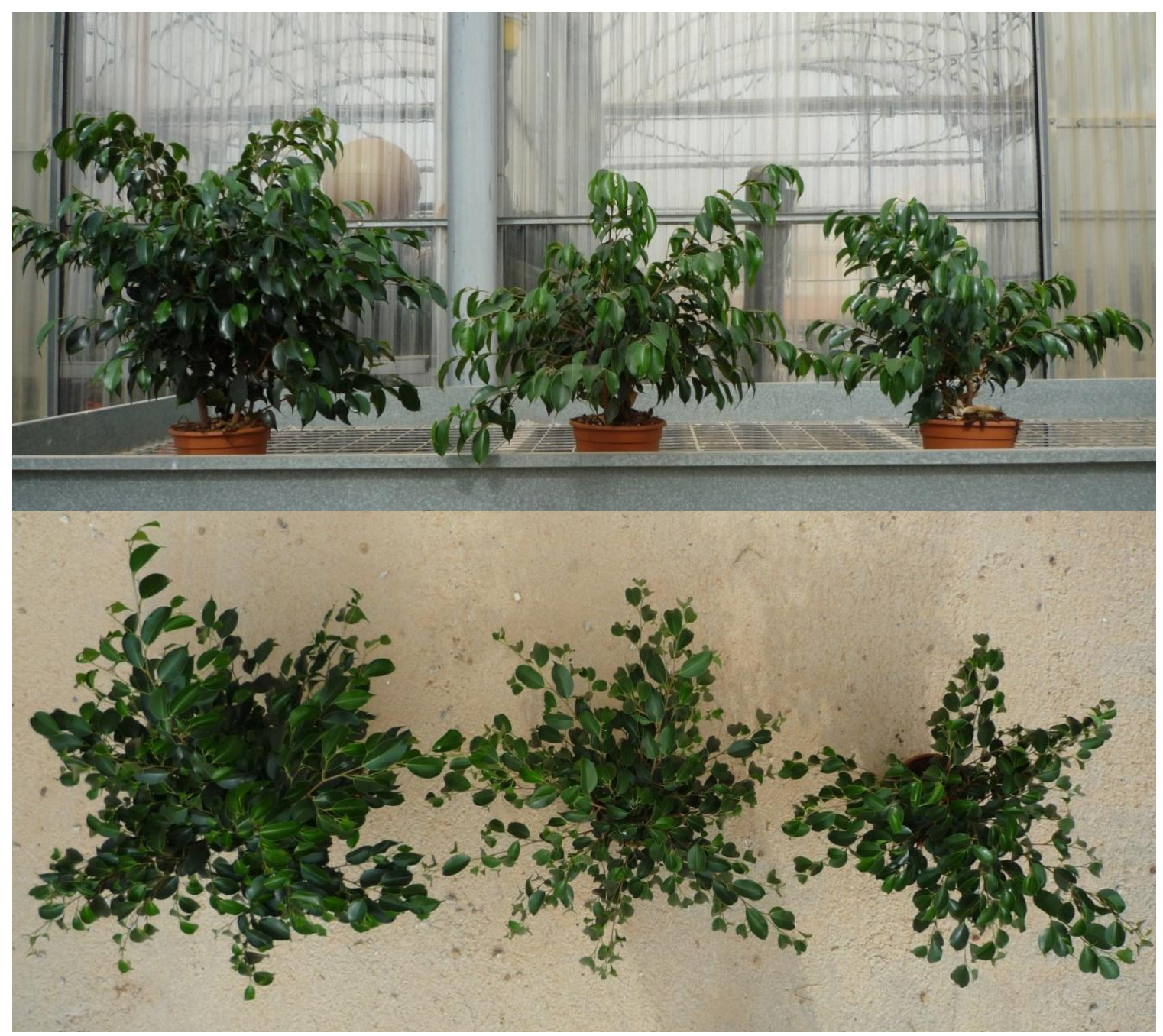

Picture 2. Ficus benjamina at the end of the experiment. From left to right control, saline reclaimed wastewater with a constant leaching (RWL) and saline reclaimed wastewater with flushing every nine irrigation events (RWF). 
Ornamental plants, however, are judged by their aesthetic value rather than growth rate or production (Wu and Dodge, 2005). As well as stunted growth, salt stress may cause foliar damage, including leaf necrosis, leaf chlorosis and marginal leaf burn; as salt stress becomes severe, premature leaf drop can occur (Niu and Cabrera, 2010). In our experiment, leaves neither dropped nor presented saline damage symptoms, but maintained a good visual appearance. However, RWF enhanced leaf lightness and chroma compared with the other treatments. None of the treatments produced a statistical difference in hue angle (Table 1). This color change in the RWF treated plants led to lighter and more saturated leaves, which was observed as slight leaf discoloration, which is regarded as a typical foliar salt damage symptom (Wu and Dodge, 2005), and which was also reflected by decreased SPAD in RWF. Compactness is another important quality criterion in ornamental plant, especially for potted plants. The compactness index tended to decrease in RW, but there was no statistical difference between treatments, suggesting the same compactness in all plants.

RWL and RWF reduced the amount of water applied to the pots (water consumption) by $52 \%$ and $61 \%$, respectively, compared with the control (Table 1), representing an important water saving with RW. While WUE was reduced in RWF, no such effect was observed in RWL since growth reduction in RWF was greater than the reduction in the water applied. Rubio et al. (2010) also found lower WUE in salinized pepper plants, whereas Karlberg et al. (2006) reported that WUE may remain unchanged or increase at high soil salinities if the plant only responds as if under water stress due to high soil osmotic potential, which leads to stomata closing. All plants had similar $\Psi_{1}$ and $\Psi_{\mathrm{p}}$ values, which pointed to no water stress under RW conditions, because ficus develops different strategies for avoiding water loss (decreased leaf area, plant size, shoot/root and SLA). The salinized ficus plants also showed a certain degree of osmotic adjustment and efficient stomatal regulation since they presented lower $\Psi_{\mathrm{o}}$ and $g_{\mathrm{s}}$ values than those irrigated with control water (Table 1). Torrecillas et al. (2003) also found that gas exchange parameters were reduced in Cistus spp. irrigated with saline water, and osmotic adjustment permitted the plants to maintain the $\Psi_{\mathrm{p}}$. 
Table 1. Effects of irrigation treatments on variables/parameters studied.

\begin{tabular}{|c|c|c|c|}
\hline \multirow{2}{*}{ Variables/Parameters } & \multicolumn{3}{|c|}{ Treatments } \\
\hline & Control & RWL & RWF \\
\hline Plant height $(\mathrm{cm})$ & $76.0 \mathrm{a}$ & $48.3 \mathrm{~b}$ & $43.8 \mathrm{~b}$ \\
\hline Plant width (cm) & $66.5 \mathrm{a}$ & $57.5 \mathrm{ab}$ & $49.5 \mathrm{~b}$ \\
\hline Blade area $\left(\mathrm{cm}^{2}\right)$ & $8.8 \mathrm{a}$ & $7.5 \mathrm{~b}$ & $6.8 \mathrm{~b}$ \\
\hline Number of leaves & $1211 \mathrm{a}$ & $531 \mathrm{~b}$ & $412 \mathrm{~b}$ \\
\hline Leaf area $\left(\mathrm{dm}^{2}\right)$ & $106.1 \mathrm{a}$ & $39.7 \mathrm{~b}$ & $27.5 \mathrm{c}$ \\
\hline Specific leaf area $\left(\mathrm{cm}^{2} \mathrm{~g}^{-1}\right)$ & $131.0 \mathrm{a}$ & $110.0 \mathrm{~b}$ & $111.2 \mathrm{~b}$ \\
\hline Plant DW (g) & $149.5 \mathrm{a}$ & $70.6 \mathrm{~b}$ & $48.8 \mathrm{c}$ \\
\hline Shoot/Root & $5.8 \mathrm{a}$ & $4.0 \mathrm{~b}$ & $3.5 \mathrm{~b}$ \\
\hline Stem diameter $(\mathrm{mm})$ & $10.5 \mathrm{a}$ & $8.1 \mathrm{~b}$ & $6.6 \mathrm{c}$ \\
\hline Final pore water $\mathrm{EC}\left(\mathrm{dS} \mathrm{m}^{-1}\right)$ & 8.9 a & $17.0 \mathrm{~b}$ & $16.7 \mathrm{~b}$ \\
\hline Average leachate EC $\left(\mathrm{dS} \mathrm{m}^{-1}\right)$ & $5.39 \mathrm{a}$ & $9.41 \mathrm{~b}$ & $9.28 \mathrm{~b}$ \\
\hline Leaf lightness & $28.4 \mathrm{~b}$ & $28.1 \mathrm{~b}$ & $32.2 \mathrm{a}$ \\
\hline Leaf chroma & $10.6 \mathrm{~b}$ & $11.7 \mathrm{~b}$ & 15.9 a \\
\hline Leaf hue angle & $115.6 \mathrm{a}$ & $117.1 \mathrm{a}$ & $115.3 \mathrm{a}$ \\
\hline Leaf SPAD & $74.1 \mathrm{~b}$ & $70.2 \mathrm{~b}$ & $67.0 \mathrm{a}$ \\
\hline Compactness index & $0.75 \mathrm{a}$ & $0.67 \mathrm{a}$ & $0.69 \mathrm{a}$ \\
\hline Water consumption $\left(\mathrm{L} \mathrm{pot}^{-1}\right)$ & $50.6 \mathrm{a}$ & $24.3 \mathrm{~b}$ & $19.6 \mathrm{c}$ \\
\hline WUE $\left(\mathrm{gDW} \mathrm{L}^{-1}\right)$ & $3.0 \mathrm{a}$ & $2.9 \mathrm{a}$ & $2.5 \mathrm{~b}$ \\
\hline$\Psi_{1}(\mathrm{MPa})$ & $-0.83 \mathrm{a}$ & $-0.93 \mathrm{a}$ & $-1.01 \mathrm{a}$ \\
\hline$\Psi_{\mathrm{p}}(\mathrm{MPa})$ & $0.43 \mathrm{a}$ & 0.39 a & $0.37 \mathrm{a}$ \\
\hline$\Psi_{\mathrm{o}}(\mathrm{MPa})$ & $-1.26 \mathrm{a}$ & $-1.31 b$ & $-1.38 b$ \\
\hline Leaf $\mathrm{Cl}^{-}\left(\mathrm{mg} \mathrm{g}^{-1} \mathrm{DW}\right)$ & $6.62 \mathrm{a}$ & $7.12 \mathrm{ab}$ & $8.64 \mathrm{~b}$ \\
\hline Leaf $\mathrm{Na}^{+}\left(\mathrm{mg} \mathrm{g}^{-1} \mathrm{DW}\right)$ & $0.95 \mathrm{a}$ & $1.20 \mathrm{a}$ & $1.21 \mathrm{a}$ \\
\hline Root $\mathrm{Cl}^{-}\left(\mathrm{mg} \mathrm{g}^{-1} \mathrm{DW}\right)$ & $15.45 \mathrm{a}$ & $15.15 \mathrm{a}$ & $18.10 \mathrm{~b}$ \\
\hline Root $\mathrm{Na}^{+}\left(\mathrm{mg} \mathrm{g}^{-1} \mathrm{DW}\right)$ & $4.86 \mathrm{a}$ & $5.08 \mathrm{a}$ & $6.10 \mathrm{~b}$ \\
\hline$g_{\mathrm{s}}\left(\mathrm{mmol} \mathrm{H} \mathrm{H}_{2} \mathrm{~m}^{2} \mathrm{~s}^{-1}\right)$ & $103.0 \mathrm{a}$ & $56.00 \mathrm{~b}$ & $3.25 \mathrm{c}$ \\
\hline$P_{\mathrm{n}}\left(\mu \mathrm{mol} \mathrm{CO} \mathrm{Cm}^{2} \mathrm{~s}^{-1}\right)$ & $15.8 \mathrm{a}$ & $8.98 \mathrm{~b}$ & $0.58 \mathrm{c}$ \\
\hline $\mathrm{F}_{\mathrm{v}} / \mathrm{F}_{\mathrm{m}}$ & $0.833 \mathrm{a}$ & $0.825 \mathrm{a}$ & $0.696 \mathrm{~b}$ \\
\hline èPSII & $0.232 \mathrm{~ns}$ & $0.234 \mathrm{~ns}$ & $0.187 \mathrm{~ns}$ \\
\hline NPQ & $2.73 \mathrm{a}$ & $2.38 \mathrm{a}$ & $1.11 \mathrm{~b}$ \\
\hline
\end{tabular}

Means within each row followed by the same letter do not differ significantly at $p \leq 0.05$.

Saline reclaimed wastewater with a constant leaching fraction of 23\% (RWL); saline reclaimed wastewater with a constant leaching fraction of $15 \%$ and flushing of $50 \%$ every nine irrigation events (RWF); water taken from a canal that delivers water from the Tagus River to the Segura River for agricultural and municipal use with a constant leaching fraction of about $15 \%$ (control). Dry weight (DW); electric conductivity (EC); water use efficiency (WUE); Leaf water potential 
$\left(\Psi_{1}\right)$, leaf osmotic potential $\left(\Psi_{\mathrm{o}}\right)$; leaf pressure potential $\left(\Psi_{\mathrm{p}}\right)$; stomatal conductance $\left(g_{\mathrm{s}}\right)$; net photosynthesis rate at midday $\left(P_{\mathrm{n}}\right)$; maximum photochemical efficiency of PSII $\left(\mathrm{F}_{\mathrm{v}} / \mathrm{F}_{\mathrm{m}}\right)$; nonphotochemical quenching (NPQ) and light adapted quantum yield of PSII (èPSII).

On the other hand, leaf $\mathrm{Cl}^{-}$concentration increased from 6.62 (control) to $8.64 \mathrm{mg} \mathrm{g}^{-}$ ${ }^{1}$ DW (RWF), but was unaffected by RWL (Table 1). Neither RWL nor RWF modified leaf $\mathrm{Na}^{+}$, although RWF slightly increased root $\mathrm{Na}^{+}$. These data indicate that ficus has a mechanism to prevent $\mathrm{Cl}^{-}$and $\mathrm{Na}^{+}$accumulation in leaves, which partly explains the absence of symptoms due to saline ion toxicity. Karlberg et al. (2006) suggested that WUE falls in saline conditions because the plant allocates relatively more photosynthates to counteract the adverse effects of salinity due to ion toxicity. In this way, the salinized ficus plants reduced their growth to avoid saline ions toxicity. The scarce differences in leaf $\mathrm{Na}^{+}$and $\mathrm{Cl}^{-}$contents in both leaf and root among treatments suggests that the ficus root has the ability to limit $\mathrm{Na}^{+}$and $\mathrm{Cl}^{-}$uptake.

The differences in water consumption among treatments are mainly related to the differences in the number of irrigation events (Fig. 1). The evolution of pot weight in the first month of the experiment points to no difference in water consumption among treatments (Fig. 1A), whereas in the last month the control plants were irrigated much more frequently than those under RWL; and the plants under RWF were irrigated less frequently than the plants under RWL (Fig. 1B). An increasing pot weight during the cultivation period indicates that the plants are growing, which was true in the control pots and partially true in RW irrigated plants because the pot weight decreased at the end of June (Fig. 1B). The reason why pot weight diminished might be due to the possibility that: a) salinity negatively affected substrate ability to retain water, and b) lower irrigation frequency under RW caused worse rehydration for the top part of the substrate. Mostafazadeh-Fard et al. (2007) reported that salinity decreases soil structure stability, and Tilt et al. (1987) found that plant growth was significantly correlated with the water retention properties of substrates. This behavior observed under RW points to an important limitation of using balances to control irrigation when there are problems in substrate rehydration or/and water retention.

Water consumption is generally related to evapotranspiration (ET). In this experiment, the control plants received more water than those irrigated with RW (Table 1), which can be attributed to a relatively high ET under good-quality water compared 
with saline water (Katerji et al., 2000). In fact, the control had a higher ET rate than the two RW treatments (Fig. 2). The ET was lower in RWF than RWL, presumably as a result of decreasing evaporation (lower water retained in bulk) and transpiration (lower leaf area and $g_{\mathrm{s}}$ ) (Fig. 2B and C). A regression study showed a significant quadratic relationship between ET and days of culture, and between ET and daily light integral (DLI) in all the treatments studied (Fig. 2). In the control, ET was strongly related with the days of culture but weakly related with DLI (Fig. 2A). Under RW, the $\mathrm{r}^{2}$ increased for ET vs. DLI and decreased for ET vs. days of culture; so, the state of development had less influence over ET when plants were irrigated with RW. The form of the curves for ET vs. days of culture changed in RW treatments compared with the control (Fig. 2). Figure 2A shows that ET increased as the days of culture increased in control conditions. However, in saline conditions, ET increased as the days of culture increase up to about 80 days, after which the slope changed and the relationship became negative, so that the ET rate fell to similar levels as in the first weeks of culture (Fig. 2B and C).

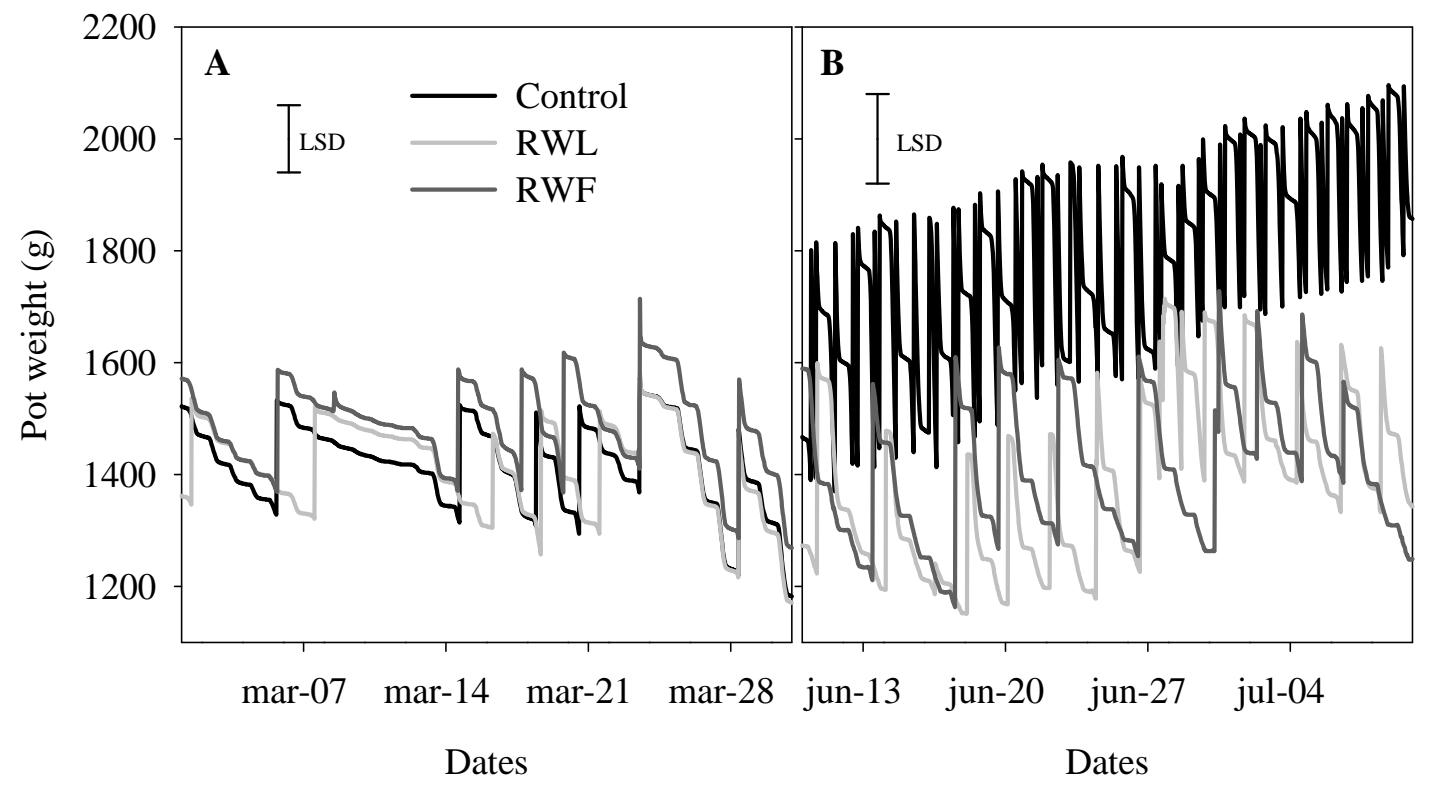

Figure 1. Thirty representative days of pot weight evolution at the beginning of experiment (from 1-March to 30-March) (A), and at the end of the experiment (from 10-June to 10-July) (B). Saline reclaimed wastewater with a constant leaching fraction of $23 \%$ (RWL); saline reclaimed wastewater with a constant leaching fraction of $15 \%$ and flushing of $50 \%$ every nine irrigation events (RWF); water taken from a canal that delivers water from the Tagus River to the Segura River for agricultural and municipal use with a constant leaching fraction of about $15 \%$ (control). Vertical bars indicate SE $(n=3)$. 
At the end of the experiment, the root zone presented a higher substrate osmotic potential due to the increasing salt content, and the salinized plants decreased their levels of gs to maintain leaf turgor (Munns, 1988). In our experiment, a substantial fall in the $g_{\mathrm{s}}$ was observed in RWL [from 103 (control) to $56 \mathrm{mmol} \mathrm{H}_{2} \mathrm{O} \mathrm{m}^{2} \mathrm{~s}^{-1}$ ], while the plants under RWF closed their stomata $\left(3.25 \mathrm{mmol} \mathrm{H}_{2} \mathrm{O} \mathrm{m}^{2} \mathrm{~s}^{-1}\right.$ of $\left.g_{\mathrm{s}}\right)$. This led to a substantial fall in $P_{\mathrm{n}}$ (43\% in RWL), while RWF showed minimal photosynthetic activity (Table 1). Ali-Dinar et al. (1999) found that salinity reduced the $P_{\mathrm{n}}$ in guava, which they attributed to stomatal closure. A fall in $P_{\mathrm{n}}$ under salinity may be due to lower $g_{\mathrm{s}}$, the depression of specific metabolic processes in carbon uptake, inhibition of photochemical capacity, or a combination of these (Seemann and Critchley, 1985). In our experiment, the decrease in $P_{\mathrm{n}}$ seems to be mainly related to stomatal factors because the decrease in $g_{\mathrm{s}}$ was followed by proportional decrease in $P_{\mathrm{n}}$.

To know whether the plants irrigated with RW were photochemically damaged, a chlorophyll fluorescence study was made. The results did not show statistical differences in maximum photochemical efficiency of PSII $\left(\mathrm{F}_{\mathrm{v}} / \mathrm{F}_{\mathrm{m}}\right)$ or non-photochemical quenching (NPQ) when control and RWL were compared, whereas RWF decreased both parameters with respect to RWL (Table 1). No statistical difference in light adapted quantum yield of PSII (èPSII) was observed among all treatments. The $F_{v} / F_{m}$ in RWF was 0.696, which is below the 0.83 regarded as the optimal value for most plant species (Johnson et al., 1993), indicating that the photosynthetic apparatus was injured. The stable èPSII and decreased $P_{\mathrm{n}}$ in RWF suggested that photochemical production was hardly used for photosynthesis, but was dissipated in photorespiration and other photochemical processes (Foyer et al., 1994). NPQ reflects the efficiency of heat dissipation, which is an essential mechanism in protecting the leaf from light-induced damage (Horton et al., 1996). In our study, NPQ remained lower in RWF than in RWL, signifying that the heat dissipation mechanism was damaged. Miralles et al. (2011) found that the decrease in NPQ was closely related to freezing injury in oleander. Thus, we believe that the diminution in NPQ with respect to the control confirms that the plants were photochemically damaged.

In conclusion, saline reclaimed wastewater can be used to produce potted weeping fig with minimal effects on plant quality, while saving water. Plant size was clearly reduced as a result of the sensitivity of ficus to salinity, which suggests that RW may be a good alternative to the chemical retardants employed in ficus production. The salinized ficus plants showed an attractive foliage because tolerance mechanisms prevented plants 
from suffering damage during saline stress (higher ability to limit $\mathrm{Na}^{+}$and $\mathrm{Cl}^{-}$uptake, stomata closing, osmotic adjustment, and reduction in leaf size, plant size, shoot/root and SLA). With regard to the two variations in LF, RWF saved more water than RWL. However, the RWF irrigated plants had a lower dry biomass and WUE than those under RWL, showed leaf discoloration and their PSII photochemistry was harmed. These findings indicate that RWL was the better irrigation-drainage combination when RW is used. 


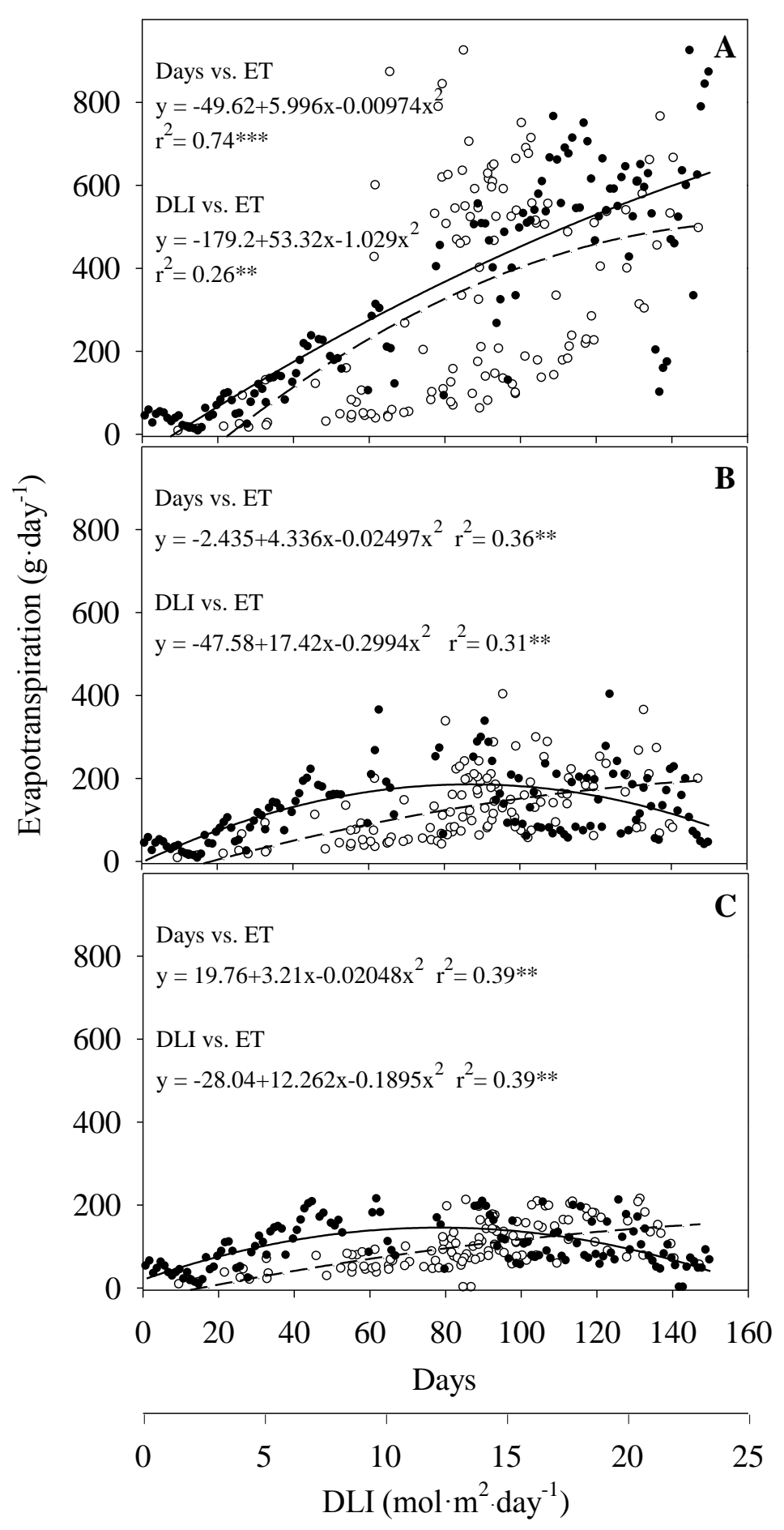

Figure 2. Daily evapotranspiration (ET) as a function of days of culture (days) and day light integral (DLI) for control (A), saline reclaimed wastewater (5 dS m-1) with a constant leaching fraction of $23 \%$ (RWL) (B), and saline reclaimed wastewater with a constant leaching fraction of $15 \%$ and flushing of $50 \%$ every nine irrigation events (RWF) (C). The continuous regression curves (open circle) indicate days vs. ET and discontinuous regression curves (filled circle) indicate DLI vs. ET. ${ }^{* *}, * * *$ : significant at $\mathrm{p} \leq 0.01$ and at $\mathrm{p} \leq 0.001$, respectively. 


\section{Acknowledgements}

We are grateful to the financial aid received from Ministerio de Economía $y$ Competitividad and the FEDER through the projects (AGL2011-30022-C02-1 and AGL2011-30022-C02-2) and SENECA project (08669/PI/08).

\section{References}

Ali-Dinar, H.M., Ebert, G., Lüdders, P., 1999. Growth, chlorophyll content. Photosynthesis and water relations in guava (Psidium guajava L.) under salinity and different nitrogen supply. Gartenbauwissenschaft 64, 54 -59.

Bañón ,S., Miralles, J., Franco, J.A., Ochoa, J., Sánchez-Blanco, M.J., 2011. Effects of diluted and pure treated wastewater on the growth, physiological status and visual quality of potted lantana and polygala plants. Sci. Hortic 129, 869-876.

Black. RJ., 2003. Salt-tolerant plants for Florida. Department of Environmental Horticulture, Florida Cooperative Extension Service, Institute of Food and Agricultural Sciences, University of Florida. Available in http://edis.ifas.ufl.edu/pdffiles/ep/ep01200.pdf [5 September 2003].

De Rijck, G., Schrevens, E., 1998. Distribution of nutrients and water in rockwool slabs. Sci. Hortic. 72, 277-285.

Fornes, F., Belda, R.M., Carrión, C., Noguera, V., García-Agustín, P., Aba, M., 2007. Preconditioning ornamental plants to drought by means of saline water irrigation as related to salinity tolerance. Sci. Hortic. 113, 52-59.

Foyer, C.H., Lelandais, M., Kunert, K.J., 1994. Photooxidative stress in plants. Physiol Plant 92, 696-717.

Horton. P., Ruban, A.V., Walters, R.G., 1996. Regulation of light harvesting in green plants. Annu. Rev. Plant Physiol. Plant Mol. Biol. 47, 655-684.

Johnson, G.N., Young, A.J., Scholes, J.D., Horton, P., 1993. The dissipation of excess excitation energy in British plant species. Plant, Cell and Environ. 16, 673-679.

Karlberg, L., Ben-Gal, A., Jansson, PE., Shani, U., 2006. Modelling transpiration and growth in salinity-stressed tomato under different climatic conditions. Ecol. Model. 190, 15-40. 
Katerji, N., van Hoorn, J.W., Hamdy, A., Mastrorilli, M., 2000. Salt tolerance classification of crops according to soil salinity and to water stress day index. Agric. Water Manage. 43, 99-109.

Katerji, N., van Hoorn, J.W., Hamdy, A., Mastrorilli, M., 2004. Comparison of corn yield response to plant water stress caused by salinity and by drought. Agric. Water Manage. 65, 95-101.

Kusaka, M., Ohta, M., Fujimura, T., 2005. Contribution of inorganic components to osmotic adjustment and leaf folding for drought tolerance in pearl millet. Physiol. Plant 125, 474-489.

Miralles, J., Nortes, P., Sánchez-Blanco, M.J., Martínez-Sánchez, J.J., Bañón, S., 2009. Above Ground and Pot-In-Pot Production Systems in Myrtus communis. Transactions of the ASABE 52,93-101.

Miralles, J., Martínez, J.A., Franco, J.A., Bañón, S., 2011. Determining Freezing Injury from Changes in Chlorophyll Fluorescence in Potted Oleander Plants. HortScience 46, 895-900.

Mostafazadeh-Fard, B., Heidarpour, M., Aghakhani, A., Feizi, M., 2007. Effects of Irrigation Water Salinity and Leaching on Soil Chemical Properties in an Arid Region. Int. J. Agric. Biol. 9, 466-469.

Munns, R., 1988. Why measure osmotic adjustment? Aust. J. Plant Physiol. 15, 717-726.

Munns, R., Husain, S., Rivelli A.R., James, R., Condon, A., Lindsay, M., Lagudah, E., Schachtman, D., Hare, R., 2002. Avenues for increasing salt tolerance of crops, and the role of physiologically based selection traits. Plant Soil 247, 93-105.

Nemali, K., van Iersel, M., 2006. An automated system for controlling drought stress and irrigation in potted plants. Sci. Hortic. 110, 292-297.

Niu, G., Cabrera, R.I., 2010. Growth and physiological responses of landscape plants to saline water irrigation - a review. HortScience 45, 605-1609.

Oron, G., DeMalach, Y., Gillerman, L., David, I., Lurie, S., 2002. Effect of water salinity and irrigation technology on yield and quality of pears. Biosyst. Eng. 81, 237-247.

Rubio, J.S., Rubio, F., Martínez, V., García-Sánchez, F., 2010. Amelioration of salt stress by irrigation management in pepper plants grown in coconut coir dust. Agric. Water Manage. 97, 1695-1702.

Seemann, J.R., Critchley, C., 1985. Effects of salt stress on the growth, ion content, stomatal behaviour and photosynthetic capacity of a salt-sensitive species, Phaseolus vulgaris L. Planta 164, 151-162. 
Tilt, K.M., Bilderback, T.E., Fonteno, W.C., 1987. Particle size and containerize effects on growth of three ornamental species. J. Amer. Soc. Hort. Sci. 112, 961-96.

Torrecillas, A., Rodríguez, P., Sánchez-Blanco, M.J., 2003. Comparison of growth, leaf water relations and gas exchange of Cistus albidus and C. monspeliensis plants irrigated with water of different $\mathrm{NaCl}$ salinity levels. Sci. Hortic. 97, 353-368.

Vogelezang, J.V., 1991. Effect of root-zone and air-temperature on growth, ornamental value and keepability of Ficus-Benjamina and Schefflera-Arboricola Compacta. Sci. Hortic. 46, 301-313.

Wright, R.D., 1986. The pour-through nutrient extraction procedure. HortScience 21, 227 229.

Wu, L., Dodge, L., 2005. A special report for the Elvenia J. Slosson Endowment Fund, Landscape salt tolerance selection guide for recycled water irrigation. University of California, Davis, CA. Available in http://slosson.ucdavis.edu/files/66355.pdf [11 September 2010].

Zwack, J.A., Graves, W.R., 1998. Leaf water relations and plant development of three freeman maple cultivars subjected to drought. J. Amer. Soc. Hort. Sci. 123, 371-375. 


\section{Chapter 2}

\section{Saline irrigation scheduling for potted geranium based on soil electrical conductivity and moisture sensors}

R. Valdés ${ }^{1}$, J. Ochoa ${ }^{1}$, J.A. Franco ${ }^{1}$, M. J. Sánchez-Blanco ${ }^{2}$ and S. Bañón ${ }^{1}$

${ }^{1}$ Departamento de Producción Vegetal. Universidad Politécnica de Cartagena. Cartagena, Spain

${ }^{2}$ Centro de Edafología y Biología Aplicada del Segura-CSIC, Murcia, Spain

Article reference:

Valdés, R., Ochoa, J., Franco, J.A., Sánchez-Blanco, M. J., Bañón, B., 2015. Saline irrigation scheduling for potted geranium based on soil electrical conductivity and moisture sensors. Agric. Water Manage. 149, 123-130.

Year 2014:

Impact factor: 2.333

Category: Agronomic

Category ranking 2013: (16/79)

Quartile in category: Q1 


\begin{abstract}
The scarcity of fresh water and the need to improve environmental management has led to saline water being used for agricultural purposes, and this, in turn, has to be managed in such a way that it minimises any damage it may cause. The use of soil moisture and electrical conductivity (EC) sensors can play an important role in this process. This work studies whether, by setting different levels of pore water $\mathrm{EC}\left(\mathrm{EC}_{\mathrm{PW}}\right)$ in a programmable automatic irrigation system connected to GS3-Decagon sensors, it is possible to create different saline conditions for cultivating geranium in pots irrigated with reclaimed wastewater of $5.5 \mathrm{dS} \mathrm{m} \mathrm{m}^{-1}$ and fresh water of $1.6 \mathrm{dS} \mathrm{m}^{-1}$ (for flushing). Five treatments were studied: the control (using fresh water) and four saline treatments programmed to provide flushing with fresh water every time that a threshold of $\mathrm{EC}_{\mathrm{PW}}$ was exceeded: 5 (T5), 5.5 (T5.5), 6 (T6) and 6.5 (T6.5) dS $\mathrm{m}^{-1}$. The saline conditions that the plants could support were evaluated in terms of growth, chlorophyll content, photosynthesis, stomatal conductance, leaf saline ion concentrations, water consumption and drainage. At the end of the experiment, the plants of T5 showed a good ornamental appearance although they had consumed $32 \%$ less total applied water than the control. The plants of the other saline treatments were excessively small and showed poor development. The automatic irrigation system using the GS3 was capable of maintaining different conditions of salinity up to $5.5 \mathrm{dS} \mathrm{m}^{-1}$ of $\mathrm{EC}_{\mathrm{PW}}$.
\end{abstract}

Key words: salinity, wastewater, probes, pot, floriculture, pelargonium

\title{
1. Introduction
}

World population growth has increased demand and competition for natural resources, while the availability of fresh water has declined. This is prompting growers to reevaluate their practices in an attempt to improve the efficient use of fresh water. One strategy for saving fresh water is to use alternative water sources such as municipal reclaimed water and other low quality waters for irrigating nurseries, gardens and landscapes. However, reclaimed wastewater may contain toxic ions and high levels of salt, a problem whose magnitude will depend on the location of any wastewater treatment plant (Bañón et al., 2011). Besides reclaimed wastewater, there may be additional sources of salt in irrigation water. For example, the intrusion of seawater into underground aquifers is a severe problem in some Mediterranean coastal areas. Salt tolerance must also be taken 
into account when considering irrigation management, since salinity reduces plant size and growth, alters plant development and can cause leaf damage (Morales et al., 2001). These effects are particularly detrimental in container-grown crops, where the growing medium is more limited than in the soil, and, as a result, the aesthetic value of ornamental plants is frequently reduced. Flowering plant production is an important horticultural industry worldwide, and Pelargonium x hortorum (zonal geranium), which is used to form clumps flowering outdoors or simply as a potted plant, is one of the most widely grown ornamental herbaceous plants in the world. Furthermore, zonal geranium is considered fairly salt tolerant (Bañón et al., 2012).

Oron et al. (2002) reported that saline water has an agricultural potential what used in combination with proper irrigation management. The accumulation of salts in the root zone can be prevented by leaching with extra irrigation water. However, the increased volume of water applied to increase the leaching fraction has a high economic and environmental cost (Katerji et al., 2004). To determine leaching it is first necessary to measure how much salt is currently in the soil/substrate, because irrigation not only applies water to a crop, but may also apply salts, water-soluble fertilizers, or both. Thus, measuring the soil solution EC is critical for the effective control of soil salinity. The availability of soil moisture sensors that are also capable to monitor soil EC has opened new possibilities for the application of a saline water irrigation scheme in horticultural crops, in particular in container cultivation (Incrocci et al., 2010). One of these is the GS3, which measures volumetric water content $(\theta)$, temperature, and bulk $\mathrm{EC}\left(\mathrm{EC}_{\mathrm{B}}\right.$, the $\mathrm{EC}$ of the water, soil and air combined) independently. This is a dielectric sensor, which, according to the manufacturer, is designed specifically for use in substrates. From the GS3 sensor output values it is possible to know the pore water $\mathrm{EC}\left(\mathrm{EC}_{\mathrm{PW}}\right.$, the $\mathrm{EC}$ "felt" by the plant) in real time and continuously, which makes it potentially suitable for maintaining salinity thresholds in soil. However, the $\mathrm{EC}_{\mathrm{PW}}$ obtained is an estimate (Hilhorst, 2000) and may not match the actual value because there are a variety of factors that can influence sensor outputs and the method of estimation (Malicki and Walczak, 1999). One of these is the soil solution salinity (Campbell, 2002; Seyfried and Murdock, 2004) and, in this sense, Bittelli (2011) indicated that the accuracy of in situ measurements of $\mathrm{EC}_{\mathrm{PW}}$ using dielectric sensors in saline soils is still problematic.

On the other hand, while information is available on the use of soil moisture sensors as a tool to reduce water consumption and adjust fertilization (Muñoz-Carpena et al., 
2008; van Iersel et al., 2009; Zotarelli et al., 2011), there is a paucity of information on the practical use of soil EC sensors to control salinization in ornamental crops. Such studies are necessary to adapt the automatic management of saline irrigation in potted plants. The aim of this study was to investigate the potential of the GS3 sensor to maintain different levels of salinity in the substrate solution of potted geranium plants irrigated with saline reclaimed wastewater (SRW), and to examine the growth and development of plants, water consumption, the accumulation of saline ions in leaves, drainage and the estimation of $\mathrm{EC}_{\mathrm{PW}}$.

\section{Materials and methods}

\subsection{Plant material and culture conditions}

Seedlings of six week old geranium Pelargonium x hortorum L.H. Bailey, cv. Master Idols Red were transplanted to $2.5 \mathrm{~L}$ PVC pots (17 cm upper internal diameter and $15 \mathrm{~cm}$ height) in the first week of April 2013. The pots were filled with a growing medium containing black peat (40\%), coconut fibre (40\%) and perlite $(20 \%)$. The experiment took place in a $100 \mathrm{~m}^{2}$ greenhouse with semicircular cover $(12.5 \mathrm{~m}$ length $\times 8 \mathrm{~m}$ width, $3.5 \mathrm{~m}$ height at the side and 5.5 at the centre) located at the Agricultural Experimental Station of the Polytechnic University of Cartagena $\left(37^{\circ} 35^{\prime} \mathrm{N}, 0^{\circ} 59^{\prime} \mathrm{W}\right)$. The pots were introduced into white pots $(24 \mathrm{~cm}$ diameter) kept in place in holes in a metal grid made of $10 \mathrm{~mm}$ diameter corrugated bars of $(16 \mathrm{~cm} \cdot 16 \mathrm{~cm}), 80 \mathrm{~cm}$ off the ground.

A data logger LOG32 (Dostmann electronic GmbH. Wertheim-Reicholzheim, Germany) was used to measure air temperature and humidity during the experimental period and these data were collected every $30 \mathrm{~min}$. Weather conditions were $17.12 \pm 3.31$ ${ }^{\circ} \mathrm{C}$ (minimum temperature) and $37.90 \pm 4.06{ }^{\circ} \mathrm{C}$ (maximum temperature); minimum relative humidity was $27.62 \pm 8.22 \%$ and the maximum $71.26 \pm 6.90 \%$. The daily light integral was calculated using the photosynthetic active radiation (PAR) measured with a quantum sensor (SQ-110; Apogee Instruments, Logan, UT), giving a value of 10.57 \pm 3.07 mol m $\mathrm{m}^{-2} \mathrm{~d}^{-1}$. 


\subsection{Irrigation treatments}

The experiment comprised five irrigation treatments: i) application of fresh water (control); ii) irrigation with SRW programmed to provide flushing with fresh water every time that the $\mathrm{EC}_{\mathrm{PW}}$ threshold was exceeded by $5 \mathrm{dS} \mathrm{m}^{-1}$ (T5); iii) by $5.5 \mathrm{dS} \mathrm{m}^{-1}$ (T5.5); iv) by $6 \mathrm{dS} \mathrm{m}^{-1}$ (T6); v) by $6.5 \mathrm{dS} \mathrm{m}^{-1}$ (T6.5). The fresh water EC was $1.6 \mathrm{dS} \mathrm{m}^{-1}$ and the SRW was $5.5 \mathrm{dS} \mathrm{m}^{-1}$ (including fertilizer). The treatments began on 23 April (after the plant establishment phase) and finished on 20 July 2013. The average volume of water applied per irrigation event (normal irrigation or flushing) was around $450 \mathrm{ml}$ in all treatments. The irrigation was controlled by a system similar to that described by Nemali and van Iersel (2006) but using a CR1000 data logger, which controlled the water pumps through an Agrónic 4000 (Sistemes Electrònics PROGRÉS, S.A., Bellpuig, Spain). The pumps were connected to 1000-L tanks containing the different irrigation solutions. GS3 sensors (Decagon Devices, Ltd., Pullman, WA) were used to measure the substrate moisture level and $\mathrm{EC}_{\mathrm{B}}$. The sensors were placed at an angle of 45 degrees in the eastfacing part of the substrate (between the two emitters in the pot), and were fully inserted into the substrate. Each pot had four emitters $\left(2 \mathrm{~L} \mathrm{~h}^{-1}\right)$ connected to a spaghetti tube, two emitters for fresh water and another two for the SRW (Picture 1). The control had two emitters per pot. The pressure-compensated drip emitters used were tested for homogeneity before the experiment started (the water flow varied between 1.9 and $2.1 \mathrm{~L}$ $\left.\mathrm{h}^{-1}\right)$.

Three GS3 sensors were used per treatment. The CR1000 was programmed to collect standard sensor readings (dielectric permittivity, temperature, and $\mathrm{EC}_{\mathrm{B}}$ ) every minute. The CR1000 calculated the average dielectric permittivity $\left(\varepsilon_{\mathrm{B}}\right)$ every thirty minutes and the $\mathrm{EC}_{\mathrm{PW}}$ every ten minutes. These average values were stored for each treatment. The $\theta$ was obtained from the stored $\varepsilon_{\mathrm{B}}$ readings using our own substratespecific calibration $\left(\theta=-0.00031 \varepsilon_{\mathrm{B}}^{2}+0.0288 \varepsilon_{\mathrm{B}}+0.0384, \mathrm{r}^{2}=0.974\right)$ determined using the procedure described by Valdés et al. (2012). The $\mathrm{EC}_{\mathrm{PW}}$ was estimated according to Hilhorst (2000):

$$
E C_{P W}=\frac{\varepsilon_{W} \cdot E C_{B}}{\varepsilon_{B}-\varepsilon_{E C_{B=0}}}
$$

where $\mathrm{EC}_{\mathrm{PW}}$ is the pore water electrical conductivity; $\varepsilon_{\mathrm{w}}$ is the real portion of the dielectric permittivity of the soil pore water, which was calculated from soil temperature (Tsoil) using: 


$$
\varepsilon_{W}=80.3-0.37(\text { Tsoil }-20)
$$

$\mathrm{EC}_{\mathrm{B}}$ is the bulk electrical conductivity measured directly by the sensor; $\varepsilon_{\mathrm{B}}$ is the real portion of the dielectric permittivity of the bulk soil; $\varepsilon_{\mathrm{ECB}=0}$ is the real portion of the dielectric permittivity when $\mathrm{EC}_{\mathrm{B}}=0$ and 3.4 for the substrate used.

Each hour, the CR1000 checked the average $\theta$, and an irrigation event took place when $\theta<0.35 \mathrm{~m}^{3} \mathrm{~m}^{-3}$. When this threshold of $\theta$ was reached and before starting irrigation the $\mathrm{CR} 1000$ calculated the average $\mathrm{EC}_{\mathrm{PW}}$ from the last irrigation event. If the average $\mathrm{EC}_{\mathrm{PW}}$ exceeded the threshold $\mathrm{EC}_{\mathrm{PW}}$ (treatments) flushing was applied. If not, SRW was applied. The data logger was programmed to count every normal irrigation and flushing event automatically.

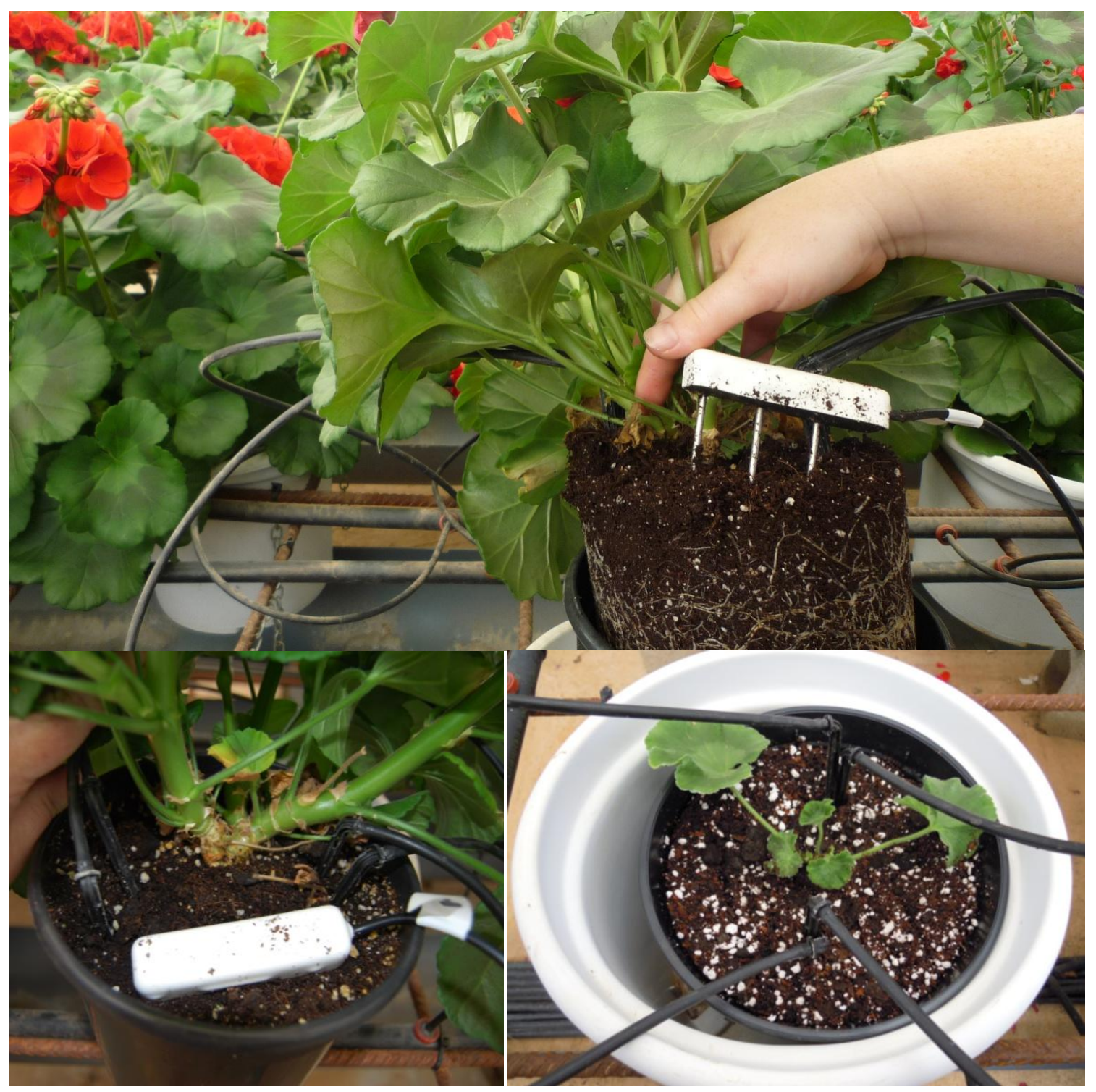

Picture 1. Details of the position of the GS3 sensor and emitters. 
Fertilization was carried out by the irrigation head, and nutrients were provided at constant concentrations in the irrigation water, containing $80 \mathrm{~N}-40 \mathrm{P}_{2} \mathrm{O}_{5}-80 \mathrm{~K}_{2} \mathrm{O}(\mathrm{ppm})$ with a $\mathrm{pH}$ of 6 . This nutrient solution was made by mixing $\mathrm{KNO}_{3}, \mathrm{NH}_{4} \mathrm{NO}_{3}, \mathrm{KH}_{2} \mathrm{PO}_{4}$ and $\mathrm{HNO}_{3}$. The added fertilizers increased the EC by approximately $0.5 \mathrm{dS} \mathrm{m}^{-1}$. The wastewater was refined by a tertiary treatment plant (Los Alcazares, Murcia). The quality of the fresh water and SRW were determined before the addition of fertilizers (Table 1).

Table 1. Ion concentrations $\left(\mathrm{mg} \mathrm{L}^{-1}\right)$ of fresh water and saline recycled wastewater (SRW).

\begin{tabular}{lcc}
\hline mg L $^{-1}$ & Fresh water & SRW \\
\hline Sodium & 78.99 & 878.27 \\
Potassium & 9.18 & 117.61 \\
Calcium & 104.01 & 277.65 \\
Magnesium & 46.49 & 180.94 \\
Chlorides & 114.11 & 1278.57 \\
Sulphates & 248.71 & 751.25 \\
Carbonates & $<5$ & $<5$ \\
Bicarbonate & 189.1 & 346.90 \\
Nitrates & 15.93 & 352.15 \\
Ammonium & $<0.10$ & 13.68 \\
Phosphates & 1.67 & 64.46 \\
Boron & 0.15 & 1.14 \\
Manganese & $<0.10$ & 1.35 \\
Iron & 0.73 & 1.10 \\
Zinc & 0.77 & 0.29 \\
Copper & - & 0.11 \\
\hline
\end{tabular}

\subsection{Measurements}

At the end of the experiment (third week of July 2013), plant height and width, number of leaves and inflorescences, shoot dry weight (SDW) and leaf area were determined in six plants per treatment. To calculate the SDW, the aerial part of the plant was placed in a natural convection bacteriological stove (model 2002471, JP Selecta SA, 
Barcelona, Spain) at $60{ }^{\circ} \mathrm{C}$, and SDW was determined by weighing. The leaf area was determined with an LI-3100C (LI-COR Biosciences, Lincoln, NE) in the same plants whose SDW was measured (Picture 2). In order to study root growth five photographs were taken of the plant root (the four sides and the bottom of the root ball) with a digital camera (Panasonic LUMIX DMC-FX07®), and the root growth index was calculated as the percentage of root area in the root ball sides, using the image analysis software for plant disease quantification ASSESS 2.0 (University of Manitoba, Winnipeg, Canada). The SPAD was measured in six plants of each treatment (four shots per plant), selecting representative south-facing, mid-height leaves. We used a SPAD-502 chlorophyll meter (Konica Minolta Sensing, Inc., Osaka, Japan), which estimates relative chlorophyll content with the light transmitted through the leaf at $650 \mathrm{~nm}$ (photosynthetically active wave length) and at $940 \mathrm{~nm}$ (Picture 2).

Evapotranspiration was measured gravimetrically by programmable balances (Analytical Sartorius, Model 5201, capacity $5.2 \mathrm{~kg}$ and readability of $0.01 \mathrm{~g}$ ) with a CR1000 programmer that recorded the weight of pots every thirty minutes. Three balances for each treatment were used. On each balance, a PVC tray slightly inclined to one side and with drainage holes was placed to collect the leachate. The total amount of water applied, the SRW applied, the fresh water applied, the leaching fraction and leachate EC $\left(\mathrm{EC}_{\mathrm{L}}\right)$ were measured in all the treatments. The leachate was collected weekly and measured gravimetrically. The leaching fraction was quantified as the volume of solution leached from the pot divided by the total volume of solution applied. $\mathrm{EC}_{\mathrm{L}}$ was analyzed immediately after collection using an EC meter (Dist ${ }^{\circledR}$ 6, Hanna Instruments S.L., Eibar, Spain).

Stomatal conductance and the net photosynthesis rate were measured using a CIRAS-2 Portable Photosynthesis System (PP Systems, Amesbury, MA). The air flow through the cuvette was $200 \mathrm{~mL} \mathrm{~min}^{-1}$ with a $\left[\mathrm{CO}_{2}\right]$ of $420 \mu \mathrm{mol} \mathrm{mol}{ }^{-1}$. The air temperature was $20{ }^{\circ} \mathrm{C}$, the vapour pressure deficit was $1.6 \mathrm{kPa}$, and the photosynthetic photon flux $1500 \mu \mathrm{mol} \mathrm{m} \mathrm{m}^{-2}$. All measurements were taken at midday in six plants per treatment during the last week end of the experiment. Two replicates were made on two days with similar weather conditions.

The chloride and sodium contents were determined in leaves. For this, dry tissue samples were ground, then, $0.2 \mathrm{~g}$ of dry tissue was added to $50 \mathrm{~mL}$ of distilled water. The solution was mixed for $30 \mathrm{~min}$ at $117 \mathrm{rpm}$ and $27^{\circ} \mathrm{C}$ using an analogue magnetic stirrer, 
model ACS-100 C/C (ITC, SL, Barcelona, Spain), and filtered. Then, $10 \mathrm{~mL}$ of the filtered dissolution were analysed using the ion chromatography method in a Metrohm 850 Ion chromatography system (Metrohm AG, Herisau, Switzerland) with an 838-861 column.

To ascertain the mean level of salinity and variations thereof during the growth cycle, the $\mathrm{EC}_{\mathrm{PW}}$ was determined throughout the cycle $\left(\mathrm{EC}_{\mathrm{PW}} \mathrm{TC}\right)$ as the mean of all the $\mathrm{EC}_{\mathrm{PW}}$ recordings (made every $30 \mathrm{~min}$ ), taking into consideration the readings of the three probes used in each treatment.

In order to know the real degree of substrate salinity, we determined the EC in water extracted from a 1:2 soil and water $\left(\mathrm{EC}_{1: 2 \mathrm{E}}\right)$, according to Camberato et al. (2009). These measurements were made independently of the experiment, using the same sensor and the same substrate with different salt contents and different volumetric water contents. Then, linear relationships were determined between $\mathrm{EC}_{\mathrm{B}}, \mathrm{EC}_{\mathrm{PW}}$ and $\mathrm{EC}_{1: 2 \mathrm{E}}$. Two linear equations were used to predict $\mathrm{EC}_{1: 2 \mathrm{E}}$ from $\mathrm{EC}_{\mathrm{B}}$ and $\mathrm{EC}_{\mathrm{PW}}$.
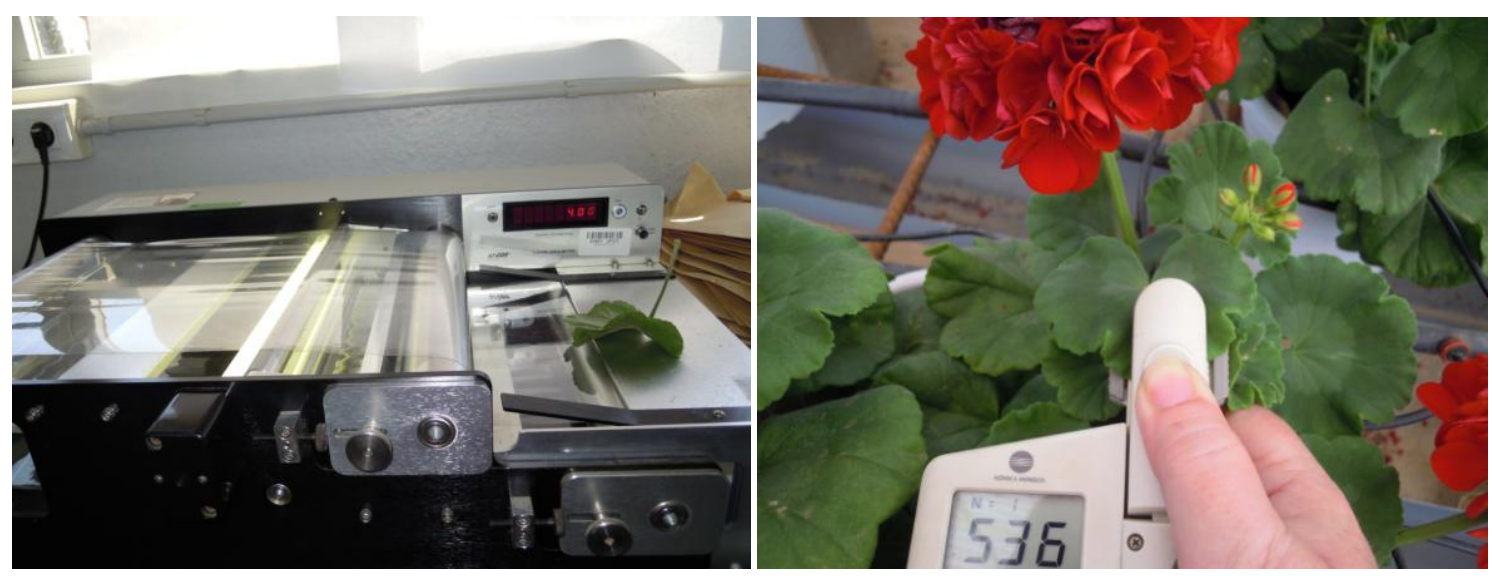

Picture 2. Details of the measurements of leaf area and SPAD.

\subsection{Experimental design and statistical analysis}

The experiment was a randomized complete block design with four blocks of eight plants per treatment set on crop tables. Treatments were analysed by one-way analysis of variance using Statgraphics Plus for Windows. Treatment averages were separated by least significant difference (LSD) $(P<0.05)$. Ratios and percentages were arcsine $(x)^{1 / 2}$ transformed before statistical analysis to ensure homogeneity of variance. The regression 
analyses were performed using SigmaPlot 10.0 software (Systat Software Inc., San Jose, CA).

\section{Results and discussion}

\subsection{Irrigation parameters and evapotranspiration}

The plants of the control treatment received the most water $\left(24.34 \mathrm{~L} \mathrm{pot}^{-1}\right)$ all of it fresh water (Table 2). The saline treatments clearly reduced the total amount of water used compared with the control, with reductions ranging from $32 \%$ (T5) to $63 \%$ (T6.5). Similar reductions were also observed for the accumulated evapotranspiration during the growing period (Fig. 1). All the saline treatments received a similar volume of SRW but different amounts of fresh water: the lower the $\mathrm{EC}_{\mathrm{PW}}$ threshold, the higher the amount of fresh water used (Table 2). This was because a low $\mathrm{EC}_{\mathrm{PW}}$ threshold was reached before a high threshold, so that, among the saline treatments, the T5 plants received the largest amount of fresh water (greatest flushing irrigation). Differences among treatments as regards the total amount of water applied were caused by the number of irrigation events: 53 for the control and from 20 to 38 for the saline treatments (Table 2).

Table 2. Applied water and the number of irrigation events for each treatment during the experimental period.

\begin{tabular}{lccccc}
\hline \multirow{2}{*}{ Parameters } & \multicolumn{5}{c}{ Treatments } \\
\cline { 2 - 6 } & Control & T5 & T5.5 & T6 & T6.5 \\
\hline Total applied water $\left(\mathrm{L} \mathrm{pot}^{-1}\right)$ & 24.34 & 16.50 & 10.64 & 9.58 & 9.02 \\
Applied wastewater $\left(\mathrm{L} \mathrm{pot}^{-1}\right)$ & 0 & 6.15 & 5.72 & 5.83 & 6.31 \\
Applied fresh water $\left(\mathrm{L} \mathrm{pot}^{-1}\right)$ & 24.34 & 10.35 & 4.92 & 3.76 & 2.71 \\
Number of irrigation events & 53 & 38 & 23 & 21 & 20 \\
Number of fresh water events & 53 & 24 & 11 & 8 & 5 \\
Number of wastewater events & - & 14 & 12 & 13 & 15 \\
\hline
\end{tabular}

Evidently, as soon as fresh water irrigation starts, the better the saline conditions for the plants, whereas the later the flushing event begins, the more severe the saline stress experienced by the plants. The T5 plants were the first to receive fresh water and so were 
exposed to a shorter saline stress period. The T5.5 plants received fresh water two weeks later than T5, while T6 and T6.5 plants received fresh water around a month later. These last two plant groups (T6 and T6.5) showed a similar level of accumulated evapotranspiration. In general, evapotranspiration increased as the threshold of $\mathrm{EC}_{\mathrm{PW}}$ decreased (Fig. 1).

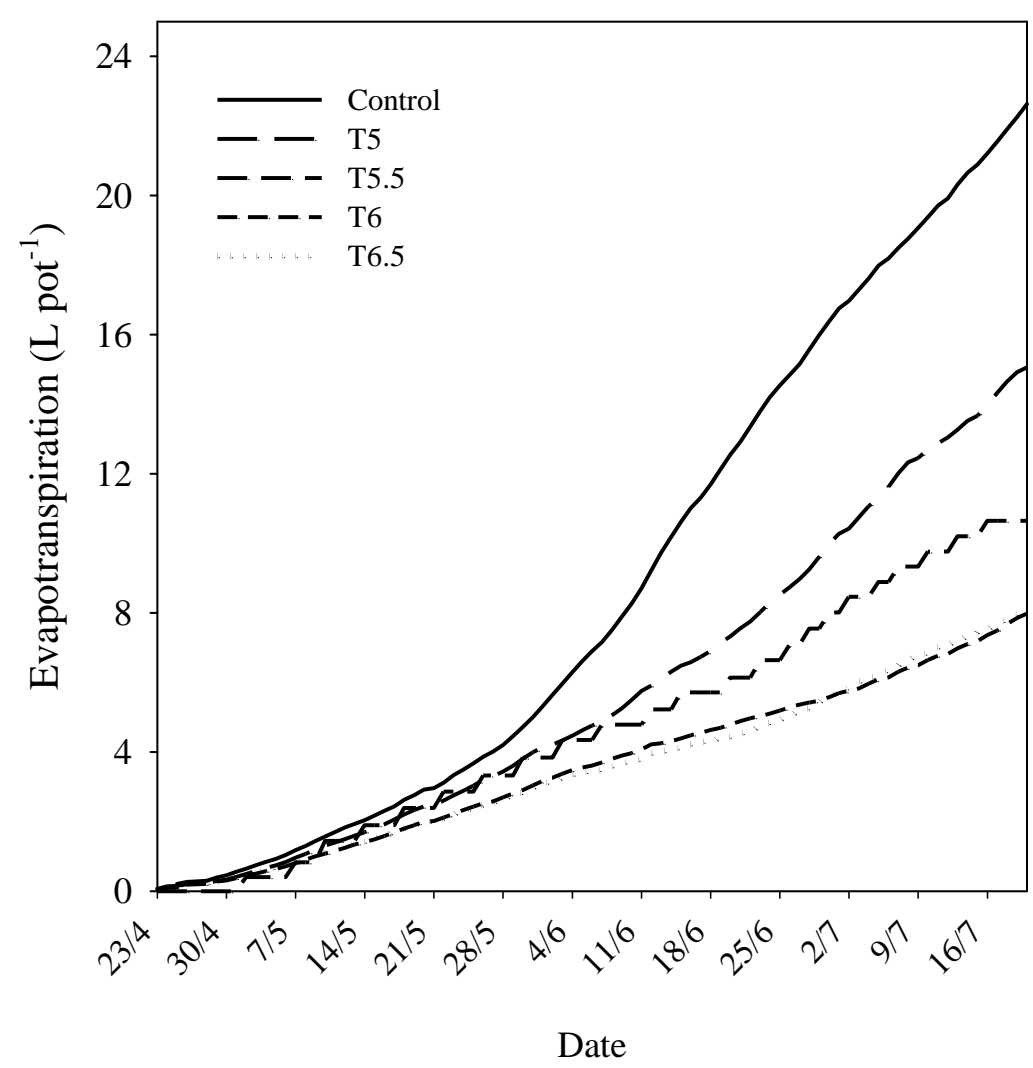

Figure 1. Evolution of the accumulated evapotranspiration throughout the experiment for five thresholds of $\mathrm{EC}_{\mathrm{PW}}$.

\subsection{Leaching and leachate EC}

The control produced the lowest leaching fraction (5.17\%), while in the saline treatments this fraction increased as the $\mathrm{EC}_{\mathrm{PW}}$ threshold increased (Table 3), pots $\mathrm{T} 6.5$ producing the greatest leaching fraction (16.22\%). Saline irrigation increased the leaching fraction because the salinated plants grew less than the control plants (lower evapotranspiration), and because root water extraction was more difficult (osmotic effect of salt ions) despite the similar root growth index (Table 3). The substrate of the control plants quickly dried out because these plants had the highest leaf area (Table 3), which is 
very important when the distribution of moisture in the substrate is not entirely uniform, as happens with drip irrigation (Valdés et al., 2014). Thus, after each irrigation event more water was retained in the substrate, reducing the leaching fraction.

The average $\mathrm{EC}_{\mathrm{L}}$ in the control pots was $6.62 \mathrm{dS} \mathrm{m}^{-1}$ (Table 3). The saline treatments produced higher $\mathrm{EC}_{\mathrm{L}}$ values than the control, and were similar to each other. The only explanation for this is that $\mathrm{EC}_{\mathrm{L}}$ depends mainly on the leaching fraction and irrigation water salinity (Torres et al., 2010). As the $\mathrm{EC}_{\mathrm{PW}}$ threshold increased, less fresh water was applied (Table 2) and the leaching fraction increased (Table 3). Both effects tended to balance the average $\mathrm{EC}_{\mathrm{L}}$ among the saline treatments.

Table 3. Effect of increasing $\mathrm{EC}_{\mathrm{PW}}$ threshold on leaching, aerial and root growth, leaf SPAD value, gas exchange and leaf chloride and sodium concentration of Pelargonium $\mathrm{x}$ hortorum "Master Idols Red" at the end of the experiment*.

\begin{tabular}{lccccc}
\hline \multirow{2}{*}{ Parameters } & \multicolumn{5}{c}{ Treatments } \\
\cline { 2 - 6 } & Control & T5 & T5.5 & T6 & T6.5 \\
\hline Leaching fraction $(\%)$ & $5.17 \mathrm{a}$ & $8.70 \mathrm{~b}$ & $9.78 \mathrm{c}$ & $12.08 \mathrm{~cd}$ & $16.22 \mathrm{~d}$ \\
Average leachate EC $\left(\mathrm{dS} \mathrm{m}^{-1}\right)$ & $6.62 \mathrm{a}$ & $8.43 \mathrm{~b}$ & $8.53 \mathrm{~b}$ & $7.69 \mathrm{~b}$ & $8.09 \mathrm{~b}$ \\
Plant width $(\mathrm{cm})$ & $34.90 \mathrm{~d}$ & $29.46 \mathrm{c}$ & $25.25 \mathrm{bc}$ & $24.79 \mathrm{ab}$ & $19.74 \mathrm{a}$ \\
Plant height $(\mathrm{cm})$ & $73.04 \mathrm{~d}$ & $57.62 \mathrm{c}$ & $47.34 \mathrm{~b}$ & $41.95 \mathrm{ab}$ & $39.17 \mathrm{a}$ \\
Shoot DW $(\mathrm{g})$ & $53.94 \mathrm{~d}$ & $40.76 \mathrm{c}$ & $24.87 \mathrm{~b}$ & $20.24 \mathrm{ab}$ & $18.91 \mathrm{a}$ \\
Leaf area $\left(\mathrm{dm}^{2}\right)$ & $40.53 \mathrm{c}$ & $31.24 \mathrm{~b}$ & $19.46 \mathrm{a}$ & $17.93 \mathrm{a}$ & $16.88 \mathrm{a}$ \\
Blade area $\left(\mathrm{cm}^{2}\right)$ & $36.98 \mathrm{~b}$ & $35.02 \mathrm{~b}$ & $25.83 \mathrm{a}$ & $29.41 \mathrm{ab}$ & $24.68 \mathrm{a}$ \\
Number of leaves & $111 \mathrm{~d}$ & $91 \mathrm{c}$ & $75 \mathrm{~b}$ & $61 \mathrm{a}$ & $68 \mathrm{ab}$ \\
Number of inflorescences & $17 \mathrm{~d}$ & $11 \mathrm{c}$ & $9 \mathrm{~b}$ & $7 \mathrm{ab}$ & $7 \mathrm{a}$ \\
Damaged leaves $(\%)$ & $13.77 \mathrm{a}$ & $16.45 \mathrm{~b}$ & $17.01 \mathrm{~b}$ & $16.88 \mathrm{~b}$ & $21.32 \mathrm{c}$ \\
Leaf SPAD & $50.91 \mathrm{~b}$ & $49.88 \mathrm{~b}$ & $52.09 \mathrm{~b}$ & $46.27 \mathrm{a}$ & $44.34 \mathrm{a}$ \\
RGI $(\%)$ & $23.02 \mathrm{a}$ & $24.5 \mathrm{a}$ & $22.2 \mathrm{a}$ & $23.55 \mathrm{a}$ & $25.21 \mathrm{a}$ \\
$g_{\mathrm{s}}\left(\mathrm{mmol} \mathrm{H}_{2} \mathrm{O} \mathrm{m}^{2} \mathrm{~s}^{-1}\right)$ & $64.25 \mathrm{~b}$ & $79.5 \mathrm{~b}$ & $76.37 \mathrm{~b}$ & $31.87 \mathrm{a}$ & $30.75 \mathrm{a}$ \\
$P_{\mathrm{n}}\left(\mu \mathrm{mol} \mathrm{CO} \mathrm{m}^{2} \mathrm{~s}^{-1}\right)$ & $6.12 \mathrm{~b}$ & $5.95 \mathrm{~b}$ & $5.83 \mathrm{~b}$ & $3.15 \mathrm{ab}$ & $1.18 \mathrm{a}$ \\
Leaf sodium $\left(\mathrm{mg} \mathrm{g}^{-1}\right)$ & $6.88 \mathrm{a}$ & $7.48 \mathrm{a}$ & $10.78 \mathrm{~b}$ & $10.88 \mathrm{~b}$ & $10.67 \mathrm{~b}$ \\
Leaf chloride $\left(\mathrm{mg} \mathrm{g}^{-1}\right)$ & $25.17 \mathrm{a}$ & $25.91 \mathrm{a}$ & $33.40 \mathrm{~b}$ & $36.07 \mathrm{bc}$ & $40.22 \mathrm{c}$ \\
\hline
\end{tabular}

*Different letters in rows indicate significant differences $(\mathrm{P} \leq 0.05)$ according to LSD test. 
DW, dry weight; SPAD, Index of relative chlorophyll content; RGI, root growth index: the percentage of root area in the root ball sides; $g_{\mathrm{s}}$, stomatal conductance; $P_{\mathrm{n}}$, net photosynthesis rate.

\subsection{Plant growth and development}

The control treatment produced the largest plants, both in height and width (Table 3 and Picture 3). An increasing $\mathrm{EC}_{\mathrm{PW}}$ threshold led to smaller plant size. However, in this experiment three plant sizes can be distinguished: the greatest (control), intermediate (T5) and the lowest (T5.5, T6, T6.5) sizes. Given that plant size is a good indicator of tolerance to salinity (Niu and Cabrera, 2010), the three plant sizes identified here could be related to different levels of saline stress. Villarino and Mattson (2011) measured the growth of Pelargonium $\mathrm{x}$ hortorum in different salinity levels, observing a significant reduction in plant width, height and shoot DW when the average substrate pour-through EC increased from 4.0 to $7.0 \mathrm{dS} \mathrm{m}{ }^{-1}$; plant width was slightly less sensitive to increasing salinity than DW as occurred in our experiment. Shoot DW also decreased with exposure to increasing $\mathrm{EC}_{\mathrm{PW}}$. The SDW most affected by salinity were those of the T6.5 plants, which showed a $65 \%$ reduction in SDW, while the T5 plants were the least affected, showing a $25 \%$ reduction with respect to control plants (Table 3). The greater the reduction in SDW, the lower the salinity tolerance of plants (Sánchez-Blanco et al., 2009). However, Navarro et al. (2011) found that geranium biomass was not reduced at 3 and $6 \mathrm{dS} \mathrm{m}^{-1}$, suggesting that it is a moderately salt tolerant species. Miyamoto (2008) classified Pelargonium spp. as moderately tolerant to salinity. Any effect of salinity on growth could be due to a fall in photosynthesis and/or disruption of their intake of ions (Navarro et al., 2007). In terms of leaf area reduction, T5.5, T6 and T6.5 were the most affected plants, with a reduction of about $56 \%$ (Table 3), while T5 was the least affected (23\% reduction compared with the control). La Fata et al. (2008) studied the influence of irrigation method on the growth of potted ivy geranium under saline and non-saline conditions, finding some reduction in leaf area, plant DW and number of shoots per plant. A reduction in leaf area may be a response to water deficit caused by salinity, due to a reduction in the transpiration surface (Bañón et al., 2006; Burnett and van Iersel, 2008). Salinity reduces elongation and cell division as blade and foliar area decrease (Munns and Tester, 2008). In this sense, the most relevant observation was that $\mathrm{T} 5$ produced plants with a similar blade size but with fewer leaves than the control (Table 3). The number of leaves and inflorescences was reduced by all the saline treatments, both parameters decreasing as the $\mathrm{EC}_{\mathrm{PW}}$ threshold increased. Among the 
saline treatments, T5 plants showed the highest number of inflorescences, while T6 and T6.5 showed the lowest (Table 3).

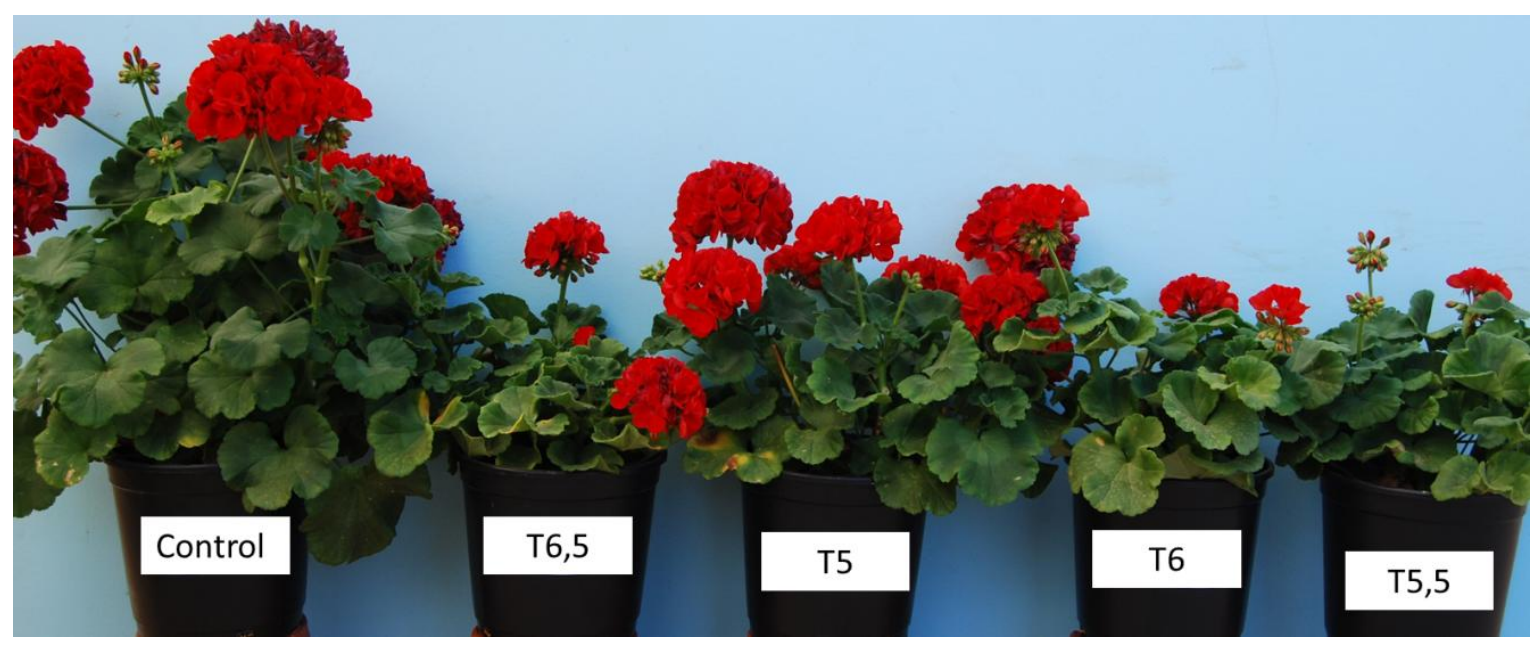

Picture 3. The developmental state of the plants at the end of the experiment.

Although growth is an important criterion for ornamental plants, more economically important for nurseries is the effect of salinity on the ornamental aspect of plants. The presence of foliar damage such as burning or chlorosis strongly affects a plant's aesthetic value (Bañón et al., 2011). The control treatment produced plants with around $14 \%$ of leaves damaged (Table 3). This only occurred in the basal leaves, and is probably a natural tendency of senescence, which is aggravated when leaves are in contact with the substrate surface. Marginal leaf necrosis was observed on Pelargonium x hortorum at EC levels higher than those used here (Huang and Cox, 1988). The plants of T5, T5.5 and T6 showed around $3 \%$ more damaged leaves than the control, rising to $8 \%$ in T6.5. In the above mentioned experiment (La Fata et al., 2008), the authors found that only the plants that had been subirrigated with saline water showed a rapid occurrence of leaf necrosis. Foliar chlorosis was assessed by measuring SPAD, which is an indicator of the relative content of chlorophylls and, therefore of leaf greenness (Monge and Bugbee, 1992). Only the leaves in T6 and T6.5 plants showed a greater degree of chlorophyll degradation (lower SPAD) than the control ones. Niu et al. (2007) observed a significant reduction in SPAD values in the leaves of different species as the severity of saline stress increased. These authors observed that salinity-sensitive species had lower SPAD values, which suggests that plants grown in T6 and T6.5 conditions were the most stressed by salt. 
No treatments modified the root growth index (Table 3), unlike that observed in the aerial organs. Several authors have noted that salinity may inhibit root growth, reducing the length and mass of roots (Shannon and Grieve, 1999). However, the reduction in shoot growth is often greater than in the roots (Munns, 2002), as was observed in this experiment.

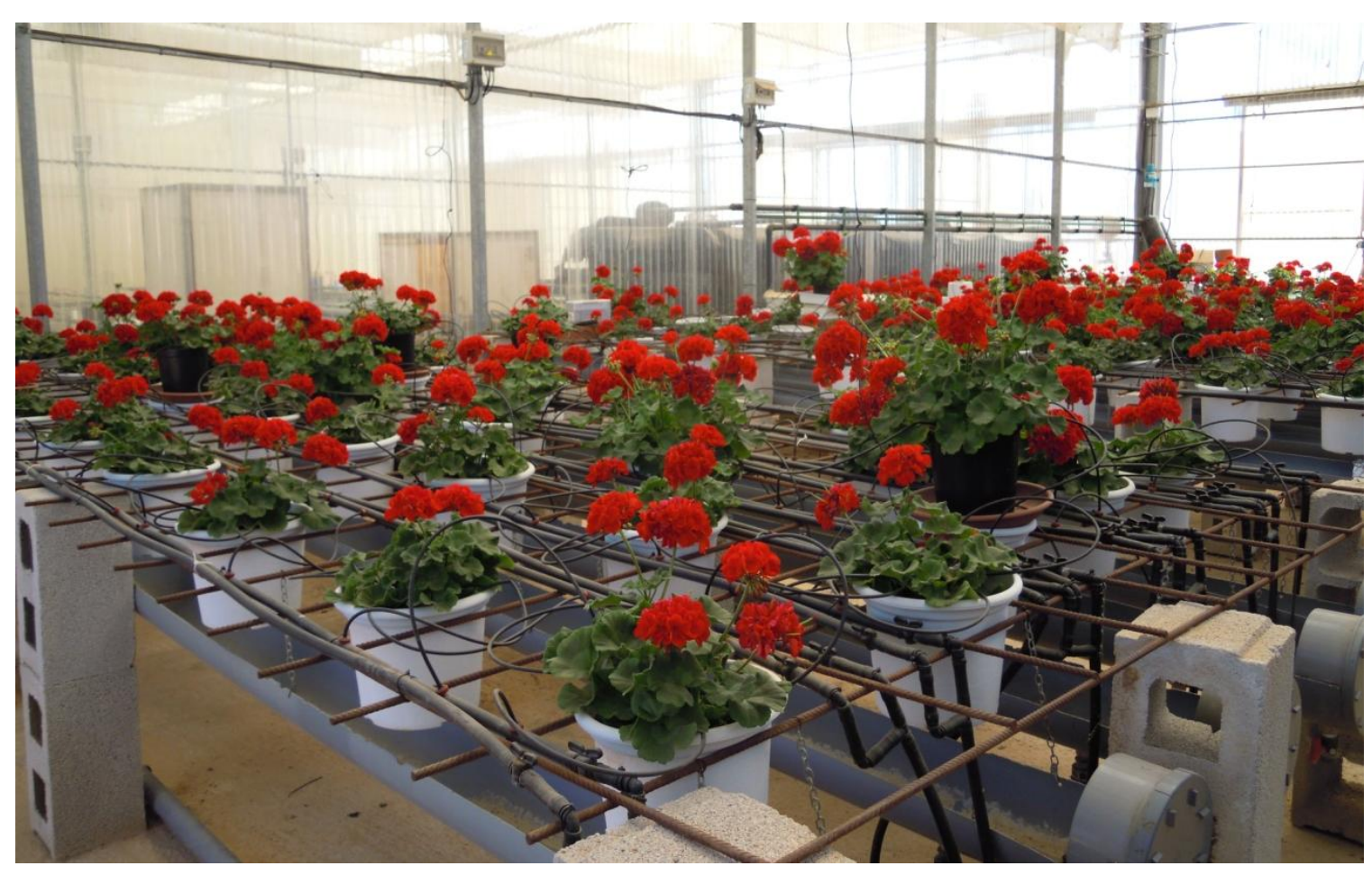

Picture 4. Cultivation at the end of the experiment.

\subsection{Gas exchange and content of saline ions in leaves}

The gas exchange values recorded for the different treatments showed that T6 and T6.5 plants had lower stomatal conductance and photosynthesis rates than the rest of salinated plants (Table 3), which could be related to the severe saline stress caused by both treatments. In the absence of any climatic stress and given that plants respond to salinity by decreasing stomatal conductance, we suggest that the T6 and T6.5 plants "perceived" the osmotic stress caused by salinity and responded with a smaller stomatal aperture to prevent further water loss (Gómez-Bellot et al., 2013). Our data suggest a relationship between stomatal conductance and the photosynthesis rate in all treatments (Table 3). Chaves et al. (2009) suggested that stomatal closure is the principal cause of reduced photosynthesis. These authors suggested that osmotic stress could affect the diffusion of 
$\mathrm{CO}_{2}$ in leaves through reductions in stomatal conductance. Reductions in growth and gas exchange in the salinated geranium plants indicate a relationship between the two parameters (Sánchez-Blanco et al., 2009). However, a decreased photosynthesis rate may also depend on non-stomatal factors, such as the accumulation of toxic ions in the leaves, and/or the reduced leaf area (Navarro et al., 2007). A previous study (Bañón et al., 2012) reported that high salinity induced plant growth reduction, principally due to the smaller leaf area available for photosynthesis rather than a restriction in net assimilation rates. In this experiment, leaves accumulated higher chloride concentration than sodium. However, Navarro et al. (2011) found a similar foliar sodium and chloride content in salinated geranium plants. Leaf chloride concentrations were significantly higher for the highest $\mathrm{EC}_{\mathrm{PW}}$ threshold (Table 3). The yellowing and necrosis observed at the leaf margins and tips of the more salinated plants might be related to the accumulation of chloride and sodium in leaves (Gómez-Bellot et al., 2013). The harmful consequences of $\mathrm{NaCl}$ salinity on the photosynthesis rate is probably due to high leaf chloride values, since the levels of chloride in the leaf tissue was proportional to the degree of photosynthesis rate reduction (Chartzoulakis and Loupassaki, 1997).

\subsection{Relationships among pore water EC, bulk EC and 1:2 extract EC}

A regression study showed a significant linear relationship between $\mathrm{EC}_{\mathrm{B}}, \mathrm{EC}_{\mathrm{PW}}$ and $\mathrm{EC}_{1: 2 \mathrm{E}}$ (Fig. 2), making the measurement of either parameter an appropriate model for predicting $\mathrm{EC}_{1: 2 \mathrm{E}}$. Incrocci et al. (2009) found a significant linear relationship between the $\mathrm{EC}_{\mathrm{PW}}$ estimated by WET sensor and the $\mathrm{EC}_{\mathrm{PW}}$ directly measured in the solution soil. Nevertheless, $\mathrm{EC}_{1: 2 \mathrm{E}}$ vs. $\mathrm{EC}_{\mathrm{B}}$ presented a stronger fit (Fig. $2 \mathrm{~A}$ ) than $\mathrm{EC}_{1: 2 \mathrm{E}} \mathrm{vs}$. $\mathrm{EC}_{\mathrm{PW}}$ (Fig. 2B), indicating that $\mathrm{EC}_{\mathrm{B}}$ can also be regarded as an appropriate indicator to ascertain substrate salinity. A modest relationship in $\mathrm{EC}_{1: 2 \mathrm{E}} \mathrm{Vs}$. $\mathrm{EC}_{\mathrm{PW}}$ suggests high variability in the $\mathrm{EC}_{\mathrm{PW}}$ values. Figure 3 shows the $\mathrm{EC}_{\mathrm{PW}} \mathrm{TC}$ and how it varied throughout the experimental period (standard error). The $\mathrm{EC}_{\mathrm{PW}} \mathrm{TC}$ of the control $\left(3.58 \mathrm{dS} \mathrm{m}^{-1}\right)$ might be related with the absence of saline stress because these plants were only irrigated with fresh water. This EC was around $5 \mathrm{dS} \mathrm{m}^{-1}$ for the saline treatments, with no statistically significant differences among them despite the different fixed $\mathrm{EC}_{\mathrm{PW}}$ thresholds. This would suggest similar saline conditions in all salinated plants, although this would not seem to be the case in light of the results seen above. As Figure 3 shows, an increasing $\mathrm{EC}_{\mathrm{PW}}$ threshold leads to increased variability in $\mathrm{EC}_{\mathrm{PW}} \mathrm{TC}$ (higher standard error). A greater variability in $\mathrm{EC}_{\mathrm{PW}} \mathrm{TC}$ 
reflects more extreme salinity conditions during the growing period, which would adversely affect the growing conditions for the plants. $\mathrm{EC}_{\mathrm{B}} \mathrm{TC}$ also increased as the $\mathrm{EC}_{\mathrm{PW}}$ threshold increased, although it showed a slightly lower variation than $\mathrm{EC}_{\mathrm{PW}}$. The values of $\mathrm{EC}_{1: 2 \mathrm{E}}$ predicted from both linear equations shown in Figure 2 were similar, around 1 $\mathrm{dS} \mathrm{m} \mathrm{m}^{-1}$ for the control and ranging from 1.25 to $1.5 \mathrm{dS} \mathrm{m}^{-1}$ for the saline treatments. According to Camberato et al. (2009), these $\mathrm{EC}_{1: 2 \mathrm{E}}$ values suggest a normal and high $\mathrm{EC}$ status for the control and saline treatments, respectively.

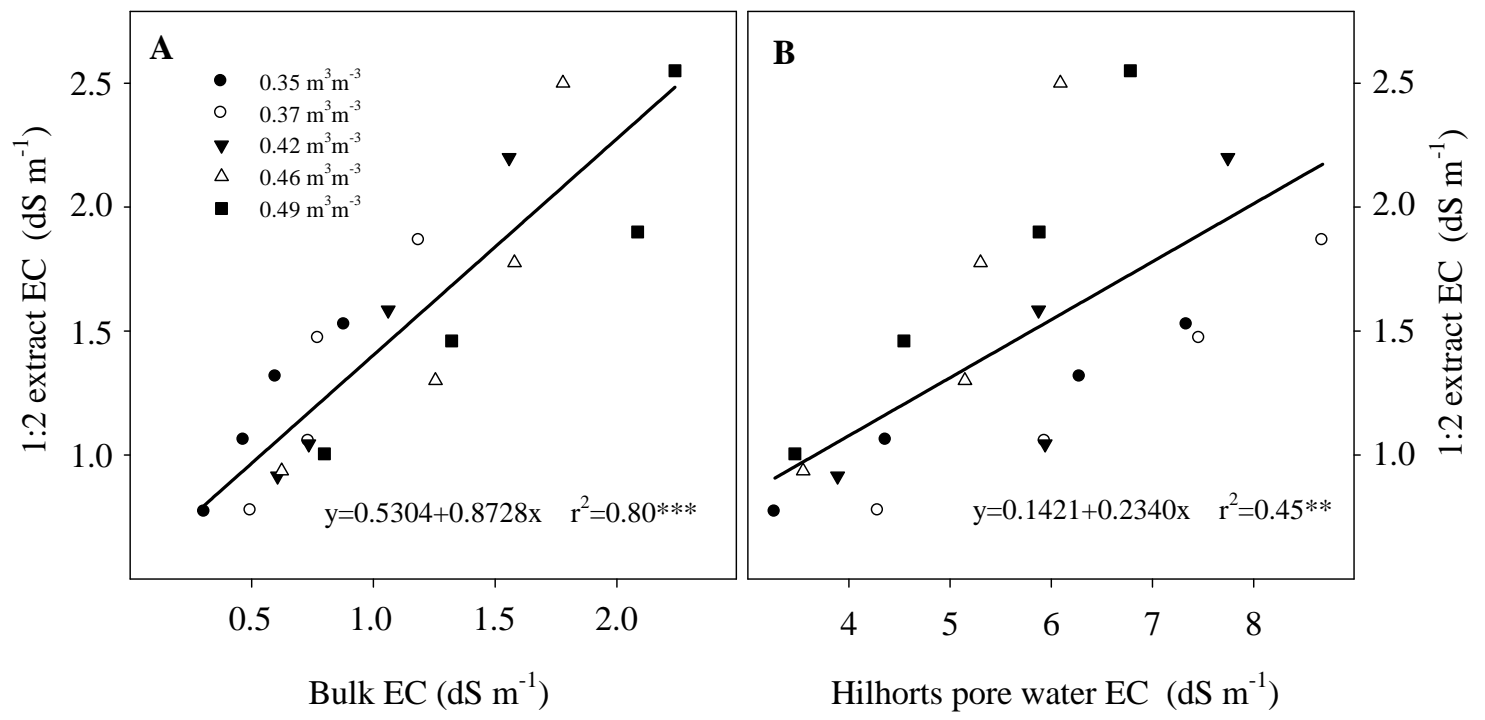

Figure 2. The relationship between bulk EC (measured by GS3-Sensor) and 1:2 soil-water extract EC (A) and the relationship between estimated pore water EC (model of Hilhorst) and 1:2 soilwater extract EC (B). The points $(\mathrm{n}=3)$ were obtained at different substrate salinity and moisture conditions. **, $* * *$ indicate significant at $P<0.01$ and $P<0.001$, respectively. 


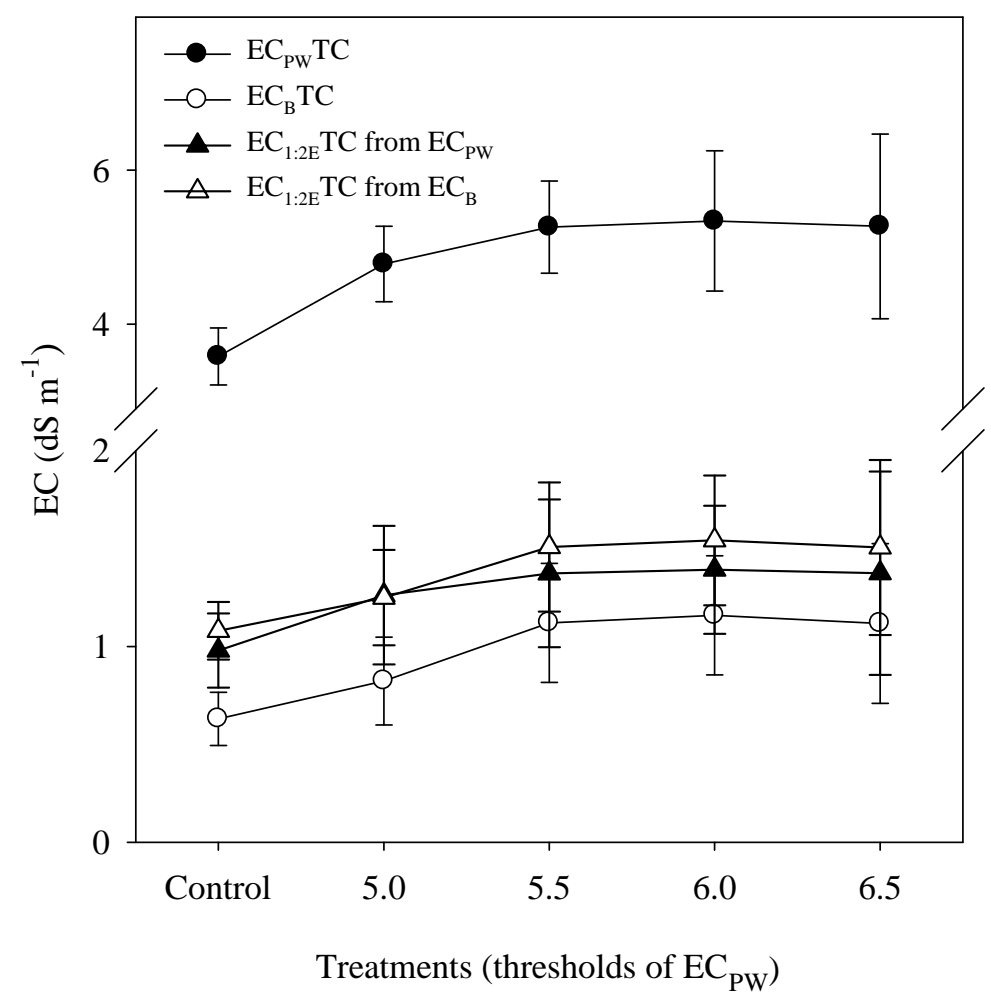

Figure 3. Values of average $\mathrm{EC}$ throughout the growing cycle. $\mathrm{EC}_{\mathrm{PW}} \mathrm{TC}$ (determined throughout the cycle as the mean of all the $\mathrm{EC}_{\mathrm{PW}}$ recordings stored every 30 minutes) and $\mathrm{EC}_{\mathrm{B}} \mathrm{TC}$ (determined throughout the cycle as the mean of all the $\mathrm{EC}_{\mathrm{B}}$ recordings stored every 30 minutes). $\mathrm{EC}_{1: 2 \mathrm{E}} \mathrm{TC}$ from $\mathrm{EC}_{\mathrm{PW}}\left(1: 2\right.$ soil-water extract $\mathrm{EC}$ values predict from $\left.\mathrm{EC}_{\mathrm{PW}}\right) . \mathrm{EC}_{1: 2 \mathrm{E}} \mathrm{TC}$ from $\mathrm{EC}_{\mathrm{B}}$ (1:2 soilwater extract $\mathrm{EC}$ values predict from $\mathrm{EC}_{\mathrm{B}}$ ). The bars indicate the standard error.

\subsection{Evolution of the volumetric water content and EC in substrate}

Figure 4 shows the evolution of $\theta, \mathrm{EC}_{\mathrm{PW}}$ and $\mathrm{EC}_{\mathrm{B}}$ during two periods of the cultivation cycle. The first period provides data from the first three weeks of the cultivation cycle, and the second provides data from three weeks in the last half of the cycle. The $\theta$ in the substrate did not fall below $0.35 \mathrm{~m}^{3} \mathrm{~m}^{-3}$ because this was the threshold value that activated irrigation. In the first weeks of cultivation all plants had a similar irrigation frequency (Fig. 4A - C). However, in the last weeks the control received more irrigation events than the saline treatments (control plants were irrigated practically every day). The number of irrigation events decreased as the saline conditions worsened (higher EC threshold and/or longer cultivation time) (Fig. 4B and C). The flushing events occurred during the second period. Thus, T5 involved continuous flushing from 21 May (see asterisks in Figure 4), while T6.5 began flushing from 22 June (Fig. 4C). In Figure 
4A (control), it can be seen that just after irrigation the value of $\theta$ increased sharply in the substrate but fell equally fast as the pot drained. The moisture curve continued to fall due to the plant's consumption of water and substrate evaporation, a fall that was particularly evident after irrigation in the morning. Salinity mitigated this behaviour because salinated plants transpire less (Fig. 1) due to their lower leaf area and stomatal conductance (Table 3), while the substrate evaporates less water because the salt helps retain it (Valdés et al., 2014). As a result irrigation takes place less frequently (Fig. 4C). Increasing saline conditions led to more erratic moisture curves, probably because the salinity level influences the $\varepsilon_{\mathrm{B}}$ (Campbell, 2002; Seyfried and Murdock, 2004; Valdés et al., 2012).

$\mathrm{EC}_{\mathrm{B}}$ increased immediately after irrigating the higher the salinity level, the greater increase (Fig. $4 \mathrm{~B}$ and $\mathrm{C}$ ). After irrigation the $\mathrm{EC}_{\mathrm{B}}$ fell gradually as the substrate water content decreased (sharply at last) because the $\mathrm{EC}_{\mathrm{B}}$ is strongly influenced by soil moisture. As matter of fact, two substrates with the same salinity but different water contents show different values of $\mathrm{EC}_{\mathrm{B}}$. On the other hand, $\mathrm{EC}_{\mathrm{PW}}$ fell after irrigating (Fig. 4) as a result of dilution and the leaching of salts in the substrate. In the control, the $\mathrm{EC}_{\mathrm{PW}}$ curve fell after irrigating and then increased sharply and remained constant (during the night) or increased gradually (during the day). $\mathrm{EC}_{\mathrm{PW}}$ tended to increase with the evaporation of water from the substrate before some salt precipitations occurred, reaching a maximum just before irrigation began (Fig. 4A). The evolution of $\mathrm{EC}_{\mathrm{PW}}$ during the saline treatments was more variable than in the control - the higher the $\mathrm{EC}_{\mathrm{PW}}$ threshold, the greater the variability (Fig. $4 \mathrm{~B}$ and $\mathrm{C}$ ) - due to the influence of salinity on the $\varepsilon_{\mathrm{B}}$ and because the $\mathrm{EC}_{\mathrm{B}}$ (and so $\mathrm{EC}_{\mathrm{PW}}$ ) is more influenced by changes in moisture when salinity is high (Malicki and Walczak, 1999; Amente et al., 2000). Nevertheless, both the $\mathrm{EC}_{\mathrm{B}}$ curve and the $\mathrm{EC}_{\mathrm{PW}}$ curve in all treatments had an upward trend throughout the experiment (Fig. 4). 


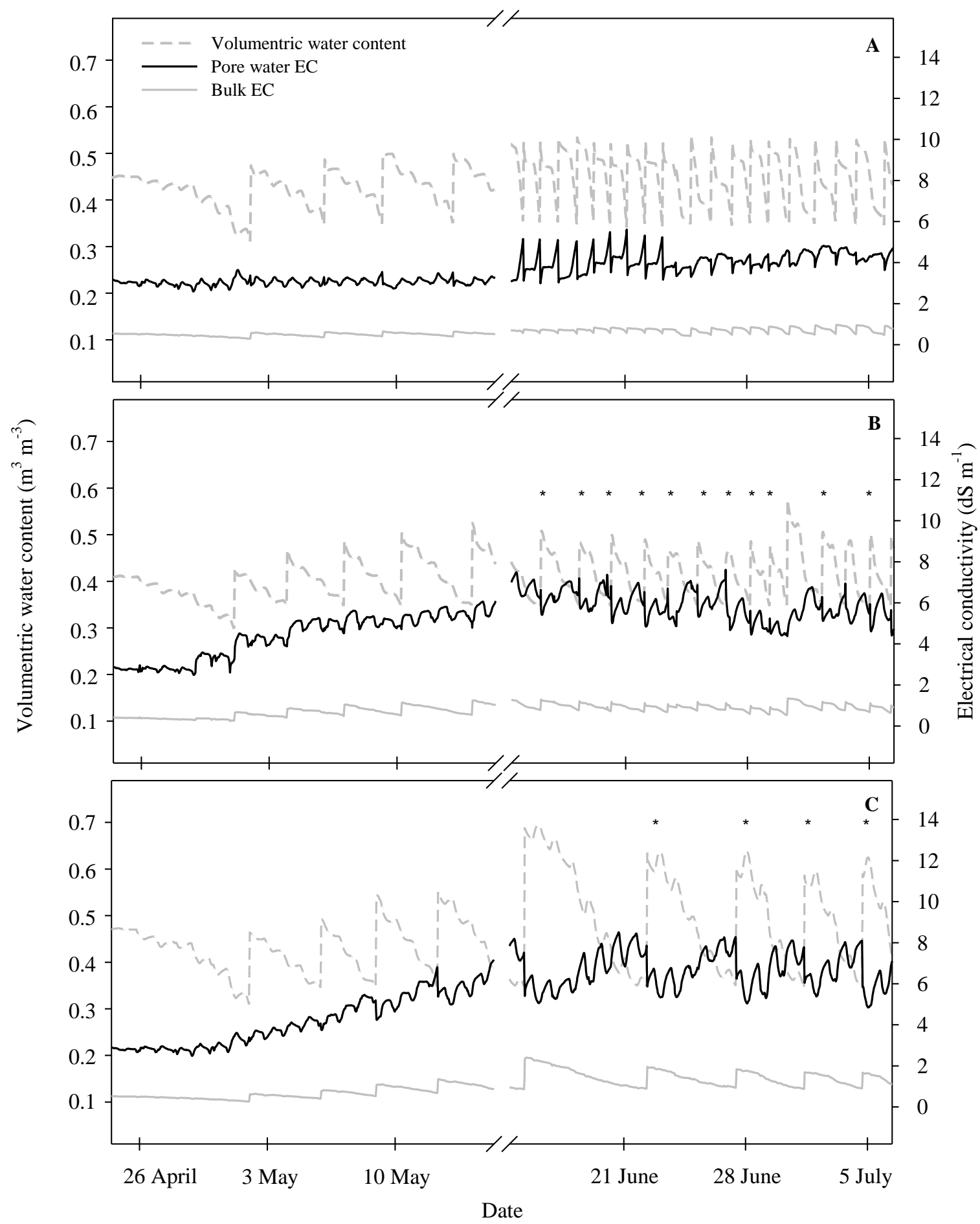

Figure 4. Evolution of volumetric water content, pore water EC and bulk EC. The control, irrigation with fresh water (A), saline irrigation with fresh water flushing every time that a threshold of $\mathrm{EC}_{\mathrm{PW}} 5 \mathrm{dS} \mathrm{m}^{-1}$ was exceeded (B) and saline irrigation with fresh water flushing every time that a threshold of $\mathrm{EC}_{\mathrm{PW}} 6.5 \mathrm{dS} \mathrm{m}^{-1}$ was exceeded (C). Two periods of the cycle of cultivation are shown, from 25 April to 15 May and from 15 June to 6 July. Asterisks indicate flushing events. 


\section{Conclusions}

In dual irrigation conditions (irrigation water $5.5 \mathrm{dS} \mathrm{m}^{-1}$ and flushing water $1.6 \mathrm{dS}$ $\mathrm{m}^{-1}$ ), the initial premise that, by fixing different $\mathrm{EC}_{\mathrm{PW}}$ thresholds in the irrigation programmer using soil EC and moisture sensors (GS3-Decagon), it would be possible to maintain different substrate salinity levels, was partially validated. When the control is compared with the two lowest $\mathrm{EC}_{\mathrm{PW}}$ thresholds of 5 and $5.5 \mathrm{dS} \mathrm{m} \mathrm{m}^{-1}$, the premise is confirmed. However, the same cannot be said when the treatments that set the $\mathrm{EC}_{\mathrm{PW}}$ threshold at 6 and $6.5 \mathrm{dS} \mathrm{m}^{-1}$ are taken into account, since the growth of plants in T5.5, T6 and T6.5 did not differ much. Nevertheless, T6.5 plants were the most damaged. The appearance of $\mathrm{T} 5$ plants made them marketable and the most pronounced difference from the control plants was their smaller size. Moreover, this treatment clearly reduced the amount of fresh water used compared with the control (by about 50\%). The rest of the saline treatments led to much greater reductions in the amount of fresh water applied but the plants were too small and poor in appearance. We suggest that the Hilhorst model for calculating the average $\mathrm{EC}_{\mathrm{PW}}$ between two irrigation events is not very accurate when salinity is high.

\section{Acknowledgements}

This research was funded by the Spanish Ministry of Economy and competitiveness MINECO (FEDER co-financing projects AGL2011-30022-C02-1 and AGL2011-30022C02-2). We would like to thank Marisol Alcaraz for her conscientious contributions to the experiment.

\section{References}

Amente, G., Baker, J.M., Reece, C.F., 2000. Estimation of soil solution electrical conductivity from bulk soil electrical conductivity in sandy soils. Soil Sci. Soc. Am. J. 64, 1931-1939.

Bañón, S., Ochoa, J., Franco, J.A., Alarcón, J.J., Sánchez-Blanco, M.J., 2006. Hardening of oleander seedlings by deficit irrigation and low air humidity. Environ. Exp. Bot. $56,36-43$. 
Bañón, S., Miralles, J., Ochoa, J., Franco, J. A., and Sánchez-Blanco, M. J., 2011. Effects of diluted and undiluted treated wastewater on the growth, physiological aspects and visual quality of potted lantana and polygala plants. Sci. Hortic. 129, 869-876.

Bañón, S., Miralles, J., Valdés, R., Conesa, E., Franco, J.A., Sánchez-Blanco, M.J., 2012a. Agronomical and physiological response of geranium to salinity and boron toxicity. Acta Hortic. (ISHS) 952, 959-965.

Bittelli, M., 2011. Measuring soil water content: a review. HortTechnology 21, 293-300.

Burnett, S.E., van Iersel, M.W., 2008. Morphology and irrigation efficiency of Gaura lindheimeri grown with capacitance sensor-controlled irrigation. HortScience 43, 1555-1560.

Camberato, D., Lopez, R., Mickelbart, M., 2009. pH and electrical conductivity measurements in soilless substrates. Purdue Univ. Ext. Serv. Bul. HO 237-W, 1-6.

Campbell, J.E., 2002. Salinity effects in capacitive soil moisture measurement. In: I.C. Paltineau (Ed.), Transactions first international symposium on soil water measurement using capacitance and impedance. Paltin International Inc., Maryland, USA, pp. 1-12.

Chartzoulakis, K., Loupassaki, M., 1997. Effects of $\mathrm{NaCl}$ salinity on germination, growth, gas exchange and yield of greenhouse eggplant. Agric. Water Manage. 32, 215-225.

Chaves, M. M., Flexas, J., Pinheiro, C., 2009. Photosynthesis under drought and salt stress: regulation mechanisms from whole plant to cell. Ann. Bot. 103, 551-560.

Gómez-Bellot, M.J., Álvarez, S., Castillo, M., Bañón, S., Ortuño, M.F., Sánchez-Blanco, M.J., 2013. Physiological mechanisms involved in the recovery of euonymus and laurustinus subjected to saline waters. Agric. Water Manage. 128, 131-139.

Hilhorst, M.A., 2000. A pore water conductivity sensor. Soil Sci. Soc. Am. J. 64, 19221925.

Huang, Z.T., Cox, D.A., 1988. Salinity effects on annual bedding plants in a peat-perlite medium and solution culture. J. Plant Nutr. 11, 145-159.

Incrocci, L., Incrocci, G., Pardossi, A., Lock, G., Nicholl, C., Balendonck, J., 2009. The calibration of wet-sensor for volumetric water content and pore water electrical conductivity in different horticultural substrates. Acta Hortic. (ISHS) 807, 289-294.

Incrocci, L., Marzialetti, P., Incrocci, G., Balendonck, J., Spagnol, S., Pardossi, A., 2010. Application of WET Sensor for Management of Reclaimed Wastewater Irrigation in Container-Grown Ornamentals (Prunus laurocerasus L.). Transactions of the Third 
International Symposium on Soil Water Measurement Using Capacitance, Impedance and TDT, Murcia, Spain, 7-9 April 2010.

Katerji, N., van Hoorn J.W., Hamdy, A., Mastrorilli, M., 2004. Comparison of corn yield response to plant water stress caused by salinity and by drought. Agric. Water Manage. 65, 95-101.

La Fata, S., Incrocci, L., Malorgio, F., Pardossi, A., Battista, P., Rapi, B., Bacci, L., 2008. The influence of irrigation method on pot geranium (Pelargonium peltatum L.) grown with saline water. Acta Hortic. (ISHS) 807, 283-288.

Malicki, M.A., Walczak, R.T., 1999. Evaluating soil salinity status from bulk electrical conductivity and permittivity. Eur. J. Soil Sci. 50, 505-514.

Miyamoto, S., 2008. Salt tolerance of landscape plants common to the southwest. Texas Water Resources Institute. Available electronically from http://thenoise.us/resources/TexasAMPlantSaltTolerance.pdf.

Monge, O.A., Bugbee, B., 1992. Inherent limitations of nondestructive chlorophyll meters: a comparison of two types of meters. HortScience 27, 69-71.

Morales, M.A., Olmos, E., Torrecillas, A., Sánchez-Blanco, M.J., Alarcón, J.J., 2001. Differences in water relations, leaf ion accumulation and excretion rates between cultivated and wild species of Limonium sp. grown in conditions of saline stress. Flora 196, 345-352.

Munns, R., 2002. Comparative physiology of salt and water stress. Plant Cell Environ. 25, 239-250.

Munns, R., Tester, M., 2008. Mechanisms of salinity tolerance. Annu. Rev. Plant Biol. 59, 651-681.

Muñoz-Carpena, R., Ritter, A., Bosch, D.D., Schaffer, B., Potter, T.L., 2008. Summer cover crop impacts on soil percolation and nitrogen leaching from a winter corn field. Agric. Water Manage. 95, 633-644.

Navarro, A., Bañón, S., Olmos, E., Sánchez-Blanco, M.J., 2007. Effects of sodium chloride on water potential components, hydraulic conductivity, gas exchange and leaf ultrastructure of Arbutus unedo plants. Plant Sci. 172, 473-480.

Navarro, A., Mastrorilli, M., Elia, A., Conversa, G., 2011. Influence of mycorrhizae in geranium irrigated with saline water: agronomic and environmental responses. Acta Hortic. (ISHS) 889, 565-572.

Nemali, K., van Iersel, M., 2006. An automated system for controlling drought stress and irrigation in potted plants. Sci. Hortic. 110, 292-297. 
Niu, G., Rodriguez, D.S., Aguiniga, L., 2007. Growth and landscape performance of ten herbaceous species in response to saline water irrigation. J. Environ. Hortic. 25, 204210.

Niu, G., Cabrera, R.I., 2010. Growth and physiological responses of landscape plants to saline water irrigation - a review. HortScience 45, 605-1609.

Oron, G., DeMalach, Y., Gillerman, L., David, I., Lurie, S., 2002. Effect of water salinity and irrigation technology on yield and quality of pears. Biosyst. Eng. 81, 237-247.

Sánchez-Blanco, M.J., Álvaraz, S., Navarro. A., Bañón, S., 2009. Changes in leaf water relations, gas exchange, growth and flowering quality in potted geranium plants irrigated with different water regimes. J. Plant Physiol. 166, 467-476.

Seyfried, M.S., Murdock, M.D., 2004. Measurement of soil water content with a $50 \mathrm{MHz}$ soil dielectric sensor. Soil Sci. Soc. Am. J. 68, 394-403.

Shannon, M.C., Grieve, C.M., 1999. Tolerance of vegetable crops to salinity. Sci. Hortic. $78,5-38$.

Torres, A.P., Mickelbart, M.V., Lopez, R.G. 2010. Leachate Volume Effects on pH and Electrical Conductivity Measurements in Containers Obtained Using the Pour-through Method. HortTechnology 20, 608-611.

Valdés, R., Miralles, J., Ochoa, J., Franco, J.A., Sánchez-Blanco, M.J., Bañón, S., 2012. Prueba de sondas para medir conductividad y humedad del sustrato en maceta en condiciones salinas. Actas del XI Simposio Hispano-Portugués de Relaciones Hídricas en las Plantas. 222-225.

Valdés, R., Miralles, J., Ochoa, J., Sánchez-Blanco, M.J., Bañón, S., 2014. The number of emitters alters salt distribution and root growth in potted gerbera. HortScience 49, 160-165.

van Iersel, M., Seymour, R.M., Chappell, M., Watson, F., Dove, S., 2009. Soil moisture sensor-based irrigation reduces water use and nutrient leaching in a commercial nursery. Proc. Southern Nursery Assoc. Res. Conf. 54, 17-21.

Villarino, G.H., Mattson, N.S., 2011. Assessing tolerance to sodium chloride salinity in fourteen floriculture species. HortTechnology 21, 539-545.

Zotarelli, L., Dukes, M.D., Scholberg, J.M.S., Femminella, K., Muñoz-Carpena, R., 2011. Irrigation scheduling for green bell peppers using capacitance soil moisture sensors. J. Irrig. Drainage Eng. 137, 73-81. 


\section{Chapter 3}

\section{Using soil bulk electrical conductivity to manage saline irrigation in the production of potted poinsettia}

R. Valdés ${ }^{1}$, J. Miralles ${ }^{1}$, J.A. Franco ${ }^{1,2}$, M. J. Sánchez-Blanco ${ }^{2,3}$ and S. Bañón ${ }^{1,2}$

${ }^{1}$ Departamento de Producción Vegetal. Universidad Politécnica de Cartagena. Cartagena, Spain

${ }^{2}$ Unidad Asociada de Horticultura Sostenible en Zonas Áridas, CEBAS-Universidad Politécnica de Cartagena, Cartagena-Murcia, Spain

${ }^{3}$ Centro de Edafología y Biología Aplicada del Segura-CSIC, Murcia, Spain

Article reference:

Valdés, R. Miralles, J. Franco, J.A., Sánchez-Blanco, M.J. Bañón, S., 2014. Using soil bulk electrical conductivity to manage saline irrigation in the production of potted poinsettia. Sci. Hortic. 170, 1-7.

Year 2013:

Impact factor: 0.855

Category: Horticulturae

Category ranking 2013: (12/33)

Quartile in category: Q2 


\begin{abstract}
Monitoring root substrate electrical conductivity (EC) is critical for the better management of irrigation water and the effective control of soil salinity. The availability of soil moisture sensors that are also capable of measuring permittivity, temperature and soil bulk EC ( $\left.\mathrm{EC}_{\mathrm{B}}\right)$, such as the Hydra Probe II (HPII, Stevens W.M.S. Inc.), has opened up new possibilities for the automatic control of saline water irrigation schemes. From such measurements, models have been developed relating the $\mathrm{EC}_{\mathrm{B}}$ to pore water $\mathrm{EC}$ $\left(\mathrm{EC}_{\mathrm{PW}}\right)$, because the latter is the $\mathrm{EC}$ that directly affects the plant. However, previous results have shown that the variability of the HPII-sensor output increases with increasing salinity, affecting the accuracy and reliability of the estimation of $\mathrm{EC}_{\mathrm{PW}}$. The purpose of this paper was to assess whether the measurements of the $\mathrm{EC}_{\mathrm{B}}$ in saturated substrate can be used to maintain different substrate saline levels, given that $\mathrm{EC}_{\mathrm{B}}$ is a function of both water content and $\mathrm{EC}_{\mathrm{PW}}$. The greenhouse study evaluated the growth and physiological status of potted poinsettia irrigated with a saline solution $\left(4.5 \mathrm{dS} \mathrm{m}^{-1}\right)$, according to three $\mathrm{EC}_{\mathrm{B}}$ thresholds $\left(1.5,2\right.$ and $\left.2.5 \mathrm{dS} \mathrm{m} \mathrm{m}^{-1}\right)$. In each treatment, when the $\mathrm{EC}_{\mathrm{B}}$ threshold was exceeded, the supply of irrigation water was doubled (flushing). Damage to plants increased (lower bract area, aerial part DW and evapotranspiration) as the $\mathrm{EC}_{\mathrm{B}}$ threshold increased. Therefore, despite not being a real reading of the soil solution salinity, it is a closely related parameter, which can be regarded as a useful tool for mitigating the negative effects of saline irrigation in the production of potted ornamental plants.
\end{abstract}

Key words: salinity, irrigation, sensor, floriculture, ornamental plant, pot plant

\title{
1. Introduction
}

Because many floriculture crops are salt-sensitive, growers have traditionally used high-quality water for irrigation. However, the availability such water is decreasing through competition between users, which is forcing growers to use low quality water (especially saline water) to irrigate ornamental crops. Salinity reduces growth, alters development and causes leaf damage; as a result, the aesthetic value of ornamental plants is reduced. These effects are accompanied by metabolic dysfunction, including a decreased photosynthetic rate and changes in enzymatic activity (Azza et al., 2007). 
Poinsettia, which is inextricably associated with the Christmas season, is one of the most popular flowering potted plants in the world. Due to its long history of cultivation and popularity, a vast library of information exists on its breeding, propagation, growth control, irrigation, nutrition, diseases and pests, and postproduction care and handling (Ecke et al., 2004). However, little is known about the use of probes to control saline irrigation. Poinsettia is considered a salt-sensitive plant (Wu and Dodge, 2005), and its cultivation problems increase rapidly as the water quality deteriorates. Usually, a water source with an electric conductivity (EC) reading of $1.5 \mathrm{dS} \mathrm{m} \mathrm{m}^{-1}$ or less is considered desirable for poinsettia. Ecke et al. (2004) suggested that it is not advisable for the fertigation solution to exceed an EC of $3 \mathrm{dS} \mathrm{m}^{-1}$, while Cavins et al. (2000) indicated that optimum substrate EC values are between 2.8 and $4.1 \mathrm{dS} \mathrm{m}^{-1}$ during active growth in poinsettia. Hence, to produce commercial poinsettias under saline irrigation, agronomical measures must be taken to reduce the negative effects of salinity. Among these, irrigation management may affect plant responses to salinity stress.

Irrigation is about water and salt, and measuring the soil EC is a good way to determine the salt content. Many sensors, including the Hydra Probe II (HPII), can measure bulk soil $\mathrm{EC}\left(\mathrm{EC}_{\mathrm{B}}\right)$, the $\mathrm{EC}$ of the water, soil and air combined. However, since $\mathrm{EC}_{\mathrm{B}}$ increases with the water content, it does not provide good enough insight to help manage irrigation. In contrast, pore water $\mathrm{EC}\left(\mathrm{EC}_{\mathrm{PW}}\right)$ is a good measurement of salinity and crop response because it is the EC "felt" by the plant. To determine the relationship between $\mathrm{EC}_{\mathrm{B}}$ and $\mathrm{EC}_{\mathrm{PW}}$ several methods and models have been developed in recent years (Rhoades et al., 1990; Hilhorst, 2000; Muñoz-Carpena et al., 2001 and Regalado et al., 2007). However, several factors may affect the reading of probes, one of them being the EC of the soil solution (Campbell, 2002 and Seyfried and Murdock, 2004). Bittelli (2011) indicated that the accuracy of in situ measurements using dielectric sensors in saline soils is still problematic. Valdés et al. (2012) identified a salinity effect on the HPII-sensor permittivity readings, with increasing data scatter as salinity increased, which affected the accuracy and reliability of the estimation of $\mathrm{EC}_{\mathrm{PW}}$.

Malicki and Walczak (1999) and Amente et al. (2000) found a significant relationship between the $\mathrm{EC}_{\mathrm{B}}$ and its water content under different levels of salinity $\left(\mathrm{EC}_{\mathrm{B}}\right.$ increasing with increasing $\theta$ ), the slope being dependent on the level of salinity (the higher the salinity, the steeper the slope). These last authors also found that the $\mathrm{EC}_{\mathrm{B}}$ at a constant $\theta$ is linearly related to $\mathrm{EC}_{\mathrm{PW}}$, with the slope increasing with increasing $\theta$. Incrocci et al. 
(2009) observed that the $\mathrm{EC}_{\mathrm{B}}$ was best related with $\mathrm{EC}_{\mathrm{PW}}$ at high $\theta$ values. From these results, it can be deduced that in a saturated substrate, the values of $\mathrm{EC}_{\mathrm{PW}}$ and $\mathrm{EC}_{\mathrm{B}}$ would be closer than in a drier substrate. Therefore, when substrate moisture is very high, the $\mathrm{EC}_{\mathrm{B}}$ could be considered more reliable for evaluating soil salinity and an alternative to $\mathrm{EC}_{\mathrm{PW}}$ when this cannot be estimated accurately (due to high salinity).

The objective of this study was to evaluate whether the use of $\mathrm{EC}_{\mathrm{B}}$ recorded by a HPII sensor can serve to maintain different levels of substrate salinity in potted poinsettia irrigated with saline water. To this end, we studied the effect of three irrigation programmers (based on the establishment of three $\mathrm{EC}_{\mathrm{B}}$ thresholds that decide the amount of water to be applied) on growth, development, gas exchange, water status, applied water and substrate and leachate salinity.

\section{Materials and methods}

\subsection{Plant material and culture conditions}

Plants of six week old poinsettias (Euphorbia pulcherrima Willd. ex Klotzsch) cv. Classic Red (Ecke Europe APS) were transplanted to $2.5 \mathrm{~L}$ PVC pots $(19 \mathrm{~cm} \Phi)$ in the last week of September 2011. The pots were filled with a growing medium containing white peat $(70 \%)$ and coconut fibre-bark (30\%). The available water and field capacity of the growing substrate were $38 \%$ and $58 \%$, respectively. The study was conducted in a greenhouse at the Agricultural Experimental Station of the Technical University of Cartagena $\left(37^{\circ} 35^{\prime} \mathrm{N}, 0^{\circ} 59^{\prime} \mathrm{W}\right)$, using four crop tables. Thirty-two pots were arranged on each of the tables in four rows of eight pots. The duration of the experimental period was eight weeks.

A datalogger (HOBO H08-004-02, MicroDAQ.com, Ltd., Contoocook, NH, USA) was used to measure air temperature and humidity with a Temperature/RH Smart Sensor S-THB-M008 (MicroDAQ.com, Ltd., Contoocook, NH, USA). Data were collected at 60 $\mathrm{s}$ intervals and averages were recorded every $30 \mathrm{~min}$. Weather conditions were $6.02 \pm 3.21$ ${ }^{\circ} \mathrm{C}$ (minimum) and $30.34 \pm 4.81^{\circ} \mathrm{C}$ (maximum); minimum relative humidity was $69.92 \pm$ $9.23 \%$ and the maximum $96.90 \pm 3.55 \%$. 


\subsection{Irrigation treatments}

The experiment comprised four irrigation treatments: a) application of fresh water; b) use of saline water with flushing when an $\mathrm{EC}_{\mathrm{B}}$ of $1.5 \mathrm{dS} \mathrm{m}{ }^{-1}$ was exceeded $\left(\mathrm{T}_{1.5}\right)$; $\left.\mathrm{c}\right)$ application of saline water with flushing when an $\mathrm{EC}_{\mathrm{B}}$ of $2 \mathrm{dS} \mathrm{m} \mathrm{m}^{-1}$ was exceeded $\left.\left(\mathrm{T}_{2}\right) ; \mathrm{d}\right)$ application of saline water with flushing when an $\mathrm{EC}_{\mathrm{B}}$ of $2.5 \mathrm{dS} \mathrm{m}^{-1}$ was exceeded $\left(\mathrm{T}_{2.5}\right)$. The fresh water EC was $1.5 \mathrm{dS} \mathrm{m}^{-1}$ and the saline water $4.5 \mathrm{dS} \mathrm{m}^{-1}$ (including fertilizer). The volume of water applied per irrigation event was around $450 \mathrm{~mL}$ in all treatments, a volume calculated to attain about $25 \%$ leaching during irrigation in the control treatment. For flushing, the volume of irrigation water was doubled.

The irrigation was controlled by a system similar to that described by Nemali and van Iersel (2006) but using a CR1000 data logger; the soil moisture level was measured by a Hydra Soil Moisture Probe (Stevens Water Monitoring Systems Inc., Beaverton, OR) and an Agrónic 4000 (Sistemes Electrònics PROGRÉS, S. A., Bellpuig, Spain) was used to control four pumps connected to four $1000 \mathrm{~L}$ tanks which contained the different irrigation solutions. Each pot had two emitters $\left(2 \mathrm{~L} \mathrm{~h}^{-1}\right)$ connected to a spaghetti tube. The pressure-compensated drip emitters used were tested for homogeneity before the experiment started (the water flow varied between 1.9 and $2.1 \mathrm{~L} \mathrm{~h}^{-1}$ ). The HPII sensor (length $12.4 \mathrm{~cm}$; diameter $4.2 \mathrm{~cm}$ ) was placed vertically in the northwest-facing part of the substrate (between the two emitters in the pot) and was fully inserted into the substrate (Picture 1). The CR1000 was programmed to collect data every minute of three HPII probes per treatment, and to calculate the average every thirty minutes (ninety data) and the standard error per treatment. The $\theta$ was obtained from the electrical permittivity $(\sigma)$ readings of the soil moisture sensor using our own substrate-specific calibration $(\theta=$ $\left.0.000231 \sigma^{2}+0.02331 \sigma+0.04449, r^{2}=0.97\right)$ determined using the procedure described by Valdés et al. (2012). Half an hour after each flushing or irrigation event, the CR1000 was programmed to store the average $\mathrm{EC}_{\mathrm{B}}$ of the following ten measurements $\left(\mathrm{EC}_{\mathrm{BAI}}\right)$. Irrigation took place when the average $\theta$ of each treatment reached the threshold of 0.40 $\mathrm{m}^{3} \mathrm{~m}^{-3}$, meaning a $47 \%$ reduction in the substrate available water; then, if the $\mathrm{EC}_{\mathrm{BAI}}$ exceeded the $\mathrm{EC}_{\mathrm{B}}$ threshold, flushing was applied. The datalogger was programmed to record the number of irrigation and flushing events.

Fertilization was carried out by the irrigation head, and nutrients were provided at constant concentrations in the irrigation water, containing $80 \mathrm{~N}-40 \mathrm{P}_{2} \mathrm{O}_{5}-80 \mathrm{~K}_{2} \mathrm{O}(\mathrm{ppm})$ at $\mathrm{pH}$ 6. This nutrient solution was made by mixing $\mathrm{KNO}_{3}, \mathrm{NH}_{4} \mathrm{NO}_{3}, \mathrm{~K}\left(\mathrm{HPO}_{4}\right)$ and $\mathrm{HNO}_{3}$. 
The fertilizers added increased EC by approximately $0.5 \mathrm{dS} \mathrm{m}^{-1}$. Therefore, the EC in the control was $1.5 \mathrm{dS} \mathrm{m}^{-1}$ and $4.5 \mathrm{dS} \mathrm{m}^{-1}$ in the saline treatments. The ion concentrations in $\mathrm{mg} \mathrm{L}^{-1}$ in the irrigation saline solution (including fertilizer) were: $\mathrm{Na}^{+}(745), \mathrm{K}^{+}(66), \mathrm{Ca}^{2+}$ (91), $\mathrm{Mg}^{2+}(51)$, chloride (1069), sulfate (297), carbonates $(<5)$, bicarbonate $(73)$, nitrates (239), ammonia (30), phosphate (68), boron (0.38), manganese (0.43), iron (0.92) and zinc (0.12). Fresh water (including fertilizer) had the following ion concentrations in $\mathrm{mg} \mathrm{L}^{-1}$ : $\mathrm{Na}^{+}(68), \mathrm{K}^{+}(63), \mathrm{Ca}^{2+}(94), \mathrm{Mg}^{2+}$ (49), chloride (92), sulfate (216), carbonates $(<5)$, bicarbonate (73), nitrates (264), ammonia (27), phosphate (77), boron (0.39), manganese (0.42), iron (1.2) and zinc (0.16).

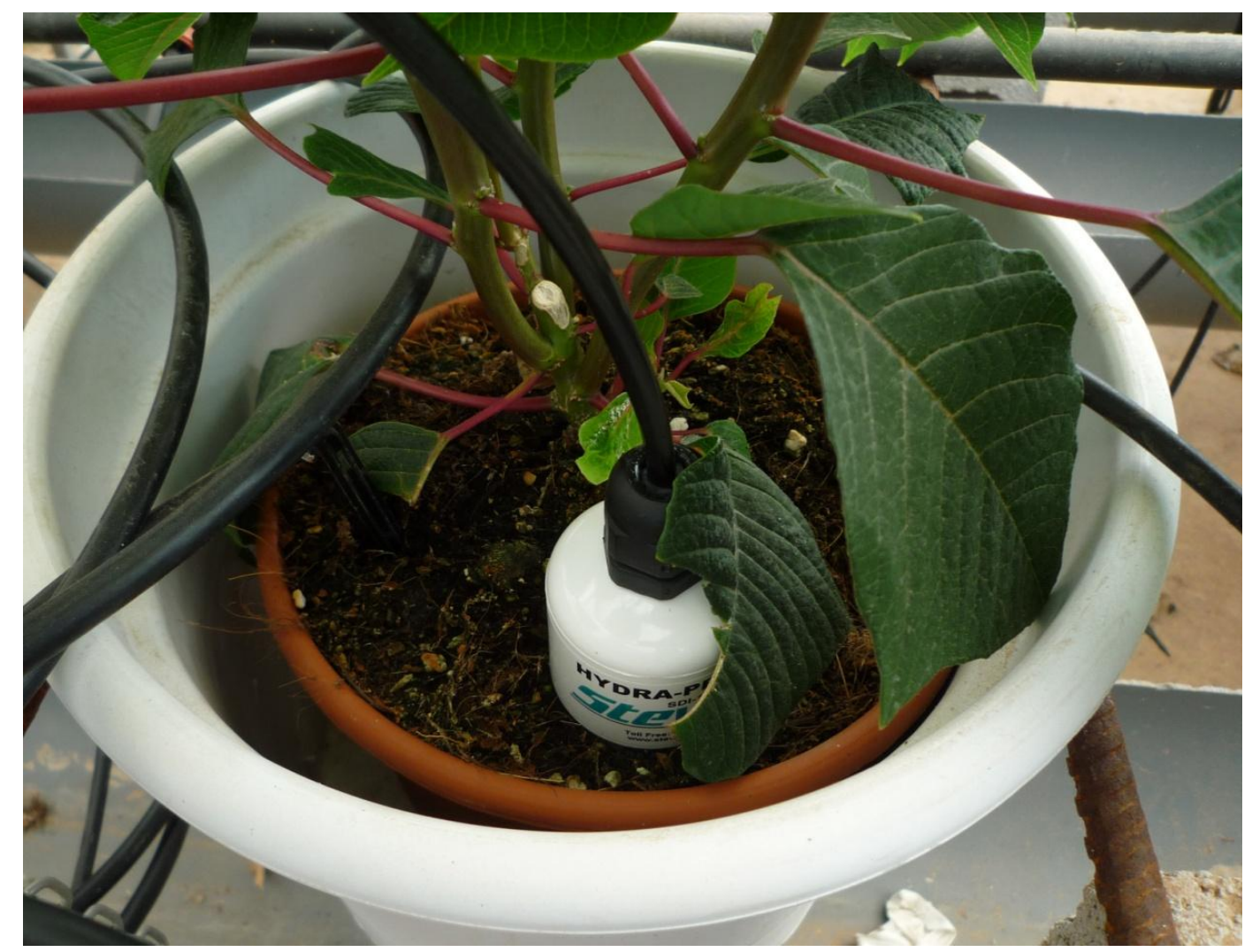

Picture 1. Details of the position of the HPII sensor and emitters.

\subsection{Measurements}

At the end of the experiment (in the third week of November 2011), plant height, plant width, the number of green leaves, the number of bracts, the number of inflorescences, the dry weight (DW) of leaves, the DW of bracts and the stem DW were determined in six plants per treatment. To calculate the DW, the plant respective parts 
were introduced in clearly identified envelopes and placed in a natural convection bacteriological stove (model 2002471, JP Selecta SA, Barcelona, Spain) at $60{ }^{\circ} \mathrm{C}$ until constant weight was reached. Finally, the DW was determined by weighing with a GRAM ST precision balance (sensitivity of $10 \mathrm{mg}$ and up to $1200 \mathrm{~g}$, Gram Precision SL, Barcelona, Spain). The bract area and the green leaf area were determined with an LI3100C (LI-COR Biosciences, Lincoln, NE) in the same plants whose DW was measured. Total foliar area was calculated by adding the green leaf area and the bract area. To calculate the root growth index (RGI) five photos were taken of the plant root, the four sides and the bottom of the root ball. Then, the percentage of root area in the root ball sides was calculated with the image analysis software for plant disease quantification ASSESS 2.0 (University of Manitoba, Winnipeg, Canada).

The SPAD was measured in six plants of each treatment (four shots per plant), selecting representative south-facing, mid-height mature plant leaves. We used a SPAD502 chlorophyll meter (Konica Minolta Sensing, Inc., Osaka, Japan), which estimates relative chlorophyll content with the light transmitted through the leaf at $650 \mathrm{~nm}$ (photosynthetically active wave length) and $940 \mathrm{~nm}$. To evaluate leaf damage (necrosis) the number of leaves with blades burned more than $25 \%$ was determined.

Evapotranspiration was measured gravimetrically by balance (Analytical Sartorius, Model 5201, Capacity $5.2 \mathrm{~kg}$ and readability of $0.01 \mathrm{~g}$ ) with a CR1000 programmer that recorded the weight every thirty minutes - three balances per treatment. On each balance, a PVC tray, slightly inclined to one side and with drainage holes, was placed so that the leachate could be collected. The trays also protected balances from water damage.

The applied water, leaching fraction and leachate EC were measured in all the treatments. The leachate was collected weekly in plastic trays and measured gravimetrically. The leaching fraction was quantified as the volume of solution leached from the pot divided by the total solution applied. Leachate EC was analyzed immediately after collection using an EC meter (Dist® 6, Hanna Instruments S.L., Eibar, Spain). The irrigation water use efficiency (IWUE) was calculated as the accumulated DW during of the experiment time divided by the water applied during the same period (determined by the CR1000).

Leaf water potential $\left(\Psi_{1}\right)$, leaf osmotic potential $\left(\Psi_{\mathrm{o}}\right)$ and leaf pressure potential $\left(\Psi_{\mathrm{p}}\right)$ were determined at midday. $\Psi_{1}$ was estimated using a Scholander pressure chamber (Soil 
Moisture Equipment Co, Santa Barbara, CA, USA) (Picture 2). Mature leaves were taken from the north-facing side (mid- height) and were enclosed in a plastic bag and sealed in the chamber within $20 \mathrm{~s}$ of collection and pressurised at a rate of $0.02 \mathrm{MPa} \mathrm{s}^{-1}$. Leaves from the $\Psi_{1}$ measurements were frozen in liquid nitrogen $\left(-170{ }^{\circ} \mathrm{C}\right)$ and stored at $-30^{\circ} \mathrm{C}$. After thawing, the sap was extracted from the sample with a small press, and then placed on a filter paper disc in the osmometer chamber and the values of the $\Psi_{\mathrm{o}}$ were measured using a WESCOR 5520 vapour pressure Osmometer (Wescor Inc., Logan, UT, USA). $\Psi_{\mathrm{p}}$ was estimated as the difference between $\Psi_{1}$ and $\Psi_{0}$ for each time. Stomatal conductance $\left(g_{\mathrm{s}}\right)$ and the net photosynthesis rate at midday $\left(P_{\mathrm{n}}\right)$ were measured at midday using a CIRAS-2 Portable Photosynthesis System (PP Systems, Amesbury, MA) (Picture 2). The air flow rate through the cuvette was $200 \mathrm{~mL} \mathrm{~min}^{-1}$ with a $\left[\mathrm{CO}_{2}\right]$ of $420 \mu \mathrm{mol} \mathrm{mol}^{-1}$, the air temperature was $20{ }^{\circ} \mathrm{C}$, the vapour pressure deficit was $1.6 \mathrm{kPa}$, and the photosynthetic photon flux $1000 \mu \mathrm{mol} \mathrm{m} \mathrm{s}^{-2}$. All measurements were taken at midday in six plants per treatment at the last week end of the experiment. Two replicates were made in two days with similar weather conditions.

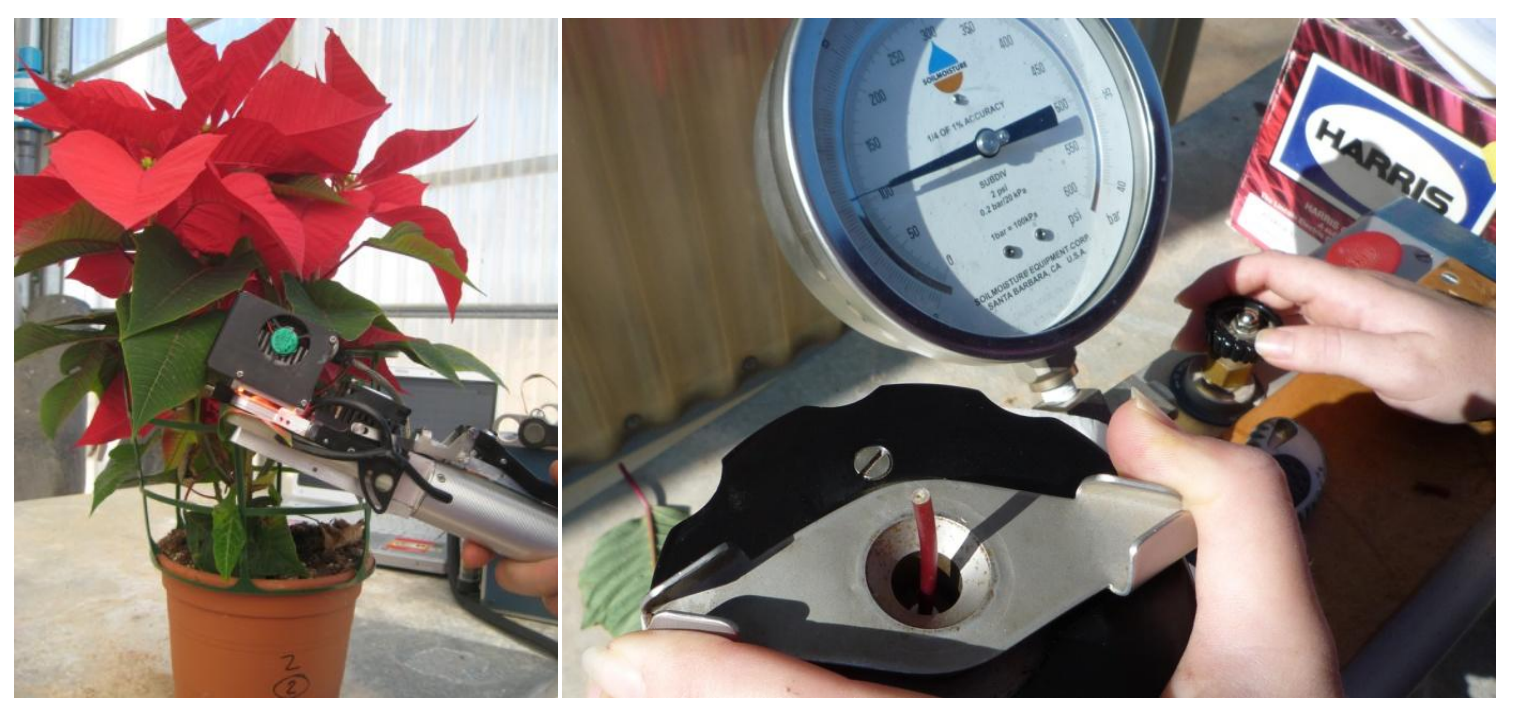

Picture 2. Details of the measurement of gas exchange and leaf water potential.

\subsection{Design and Statistical Analysis}

The experiment was a randomized complete block design with four blocks of eight plants per treatment set on crop tables. Treatments were analysed by one-way analysis of variance using Statgraphics Plus for Windows. Treatment averages were separated by 
least significant difference (LSD) $(\mathrm{p}<0.05)$. Ratios and percentages were $\operatorname{arcsine}(\mathrm{x})^{1 / 2}$ transformed before statistical analysis to ensure homogeneity of variance.

\section{Results}

\subsection{Growth and development}

Treatment $\mathrm{T}_{1.5}$ produced plants of similar height and diameter as the control, while $\mathrm{T}_{2}$ and $\mathrm{T}_{2.5}$ produced smaller plants (both in height and width) than the control and $\mathrm{T}_{1.5}$ (Table 1 and Picture 3). The number of leaves per plant (green leaves and bracts) was only reduced by $T_{2.5}$. The saline treatments tended to reduce the number of green leaves compared with the control, the decrease being statistically significant in the case of $T_{2}$ and $\mathrm{T}_{2.5}$, this last treatment producing plants with the lowest number of green leaves. In contrast, salinity tended to increase the presence of bracts. Salinity also induced precocity in bract color formation because all saline treatments showed first color on 20 October, while the control did so five days later. Furthermore, at the end of the cultivation period only the plants from $\mathrm{T}_{2}$ presented more bracts than the control, while no treatment produced changes in the number of inflorescences per plant (Table 1). Salinity induced damage in the basal leaves of treatments $T_{2}$ and, particularly, $T_{2.5}$ (Table 1 and Picture 4). This process began with chlorosis at the edges of the leaf apex, which spread towards the centre, the leaf finally turning brown (dry) and shrivelling towards the lower surface. Some of these leaves dried up completely without falling. However, neither the control nor $\mathrm{T}_{1.5}$ produced such damage.

Salinity clearly reduced the aerial part DW of the plants, the reduction increasing as the threshold of $\mathrm{EC}_{\mathrm{B}}$ increased, which was particularly evident in the case of $\mathrm{T}_{2.5}$ (about $48 \%$ reduction compared with the control). This reduction in aerial part DW affected the green leaves, bracts and stems. When $\mathrm{T}_{1.5}$ and $\mathrm{T}_{2}$ were compared, the DW of green leaves, bracts and stems were seen to be lower in $T_{2}$, but when $T_{2}$ and $T_{2.5}$ were compared, only the bract DW was significantly reduced in $\mathrm{T}_{2.5}$. The control plants showed a higher root growth index (RGI), while the plants of $\mathrm{T}_{2}$ and $\mathrm{T}_{2.5}$ showed a lower but similar RGI, and $\mathrm{T}_{1.5}$ produced an RGI between the two other treatments and the control (Table 1). $\mathrm{T}_{1.5}$ reduced the total leaf area by $27 \%$ with respect to the control, a reduction that affected both green leaves and bracts. Treatments $T_{2}$ and $T_{2.5}$ also reduced total leaf area with respect to the control and $\mathrm{T}_{1.5}$, while the lowest total leaf area was recorded in $\mathrm{T}_{2.5}$. This 
last treatment produced a bract area lower than $\mathrm{T}_{2}$, although the green leaf area was similar. The salinity levels of $T_{1.5}$ and $T_{2}$ reduced leaf SPAD to a similar extent, while $T_{2.5}$ led to the lowest values (Table 1).

Table 1. Growth, development and leaf SPAD.

\begin{tabular}{lccccc}
\hline \multirow{2}{*}{ Parameters } & \multicolumn{5}{c}{ Treatments } \\
\cline { 2 - 5 } & Control & $\mathrm{T}_{1.5}$ & $\mathrm{~T}_{2}$ & $\mathrm{~T}_{2.5}$ & Signification \\
\hline Plant height $(\mathrm{cm})$ & $44.24 \mathrm{~b}$ & $40.00 \mathrm{~b}$ & $34.54 \mathrm{a}$ & $32.26 \mathrm{a}$ & $* * *$ \\
Plant width $(\mathrm{cm})$ & $72.94 \mathrm{c}$ & $64.01 \mathrm{~b}$ & $56.06 \mathrm{a}$ & $51.83 \mathrm{a}$ & $* * *$ \\
Total number of leaves & $121.00 \mathrm{~b}$ & $120.00 \mathrm{~b}$ & $123.50 \mathrm{~b}$ & $103.25 \mathrm{a}$ & $*$ \\
Number of green leaves & $57.75 \mathrm{c}$ & $51.00 \mathrm{bc}$ & $48.75 \mathrm{~b}$ & $42.25 \mathrm{a}$ & $*$ \\
Damaged green leaves $(\%)$ & $0.0 \mathrm{a}$ & $0.0 \mathrm{a}$ & $8.5 \mathrm{~b}$ & $14.3 \mathrm{c}$ & $* *$ \\
Number of bracts & $63.25 \mathrm{a}$ & $69.00 \mathrm{ab}$ & $74.75 \mathrm{~b}$ & $61.00 \mathrm{a}$ & $* *$ \\
Number of inflorescences & 6.25 & 5.00 & 6.00 & 5.50 & $\mathrm{~ns}$ \\
Aerial part dry weight $(\mathrm{g})$ & $38.42 \mathrm{~d}$ & $29.41 \mathrm{c}$ & $23.85 \mathrm{~b}$ & $19.96 \mathrm{a}$ & $* * *$ \\
Leaf dry weight $(\mathrm{g})$ & $14.13 \mathrm{c}$ & $10.53 \mathrm{~b}$ & $8.36 \mathrm{a}$ & $7.33 \mathrm{a}$ & $* * *$ \\
Bract dry weight $(\mathrm{g})$ & $12.38 \mathrm{~d}$ & $10.36 \mathrm{c}$ & $8.67 \mathrm{~b}$ & $5.88 \mathrm{a}$ & $* * *$ \\
Stem dry weight $(\mathrm{g})$ & $11.90 \mathrm{c}$ & $8.52 \mathrm{~b}$ & $6.81 \mathrm{a}$ & $6.75 \mathrm{a}$ & $* * *$ \\
Root growth index $(\%)$ & $31.88 \mathrm{c}$ & $25.56 \mathrm{~b}$ & $19.36 \mathrm{a}$ & $19.00 \mathrm{a}$ & $* *$ \\
Total foliar area $\left(\mathrm{dm}{ }^{2}\right)$ & $76.89 \mathrm{~d}$ & $56.20 \mathrm{c}$ & $44.31 \mathrm{~b}$ & $39.33 \mathrm{a}$ & $* *$ \\
Green leaf area $\left(\mathrm{dm}^{2}\right)$ & $31.11 \mathrm{c}$ & $21.39 \mathrm{~b}$ & $16.68 \mathrm{a}$ & $18.92 \mathrm{a}$ & $*$ \\
Bract area $\left(\mathrm{dm}^{2}\right)$ & $45.77 \mathrm{~d}$ & $34.80 \mathrm{c}$ & $27.63 \mathrm{~b}$ & $20.40 \mathrm{a}$ & $* * *$ \\
Leaf SPAD & $51.91 \mathrm{c}$ & $46.11 \mathrm{~b}$ & $43.64 \mathrm{~b}$ & $37.6 \mathrm{a}$ & $* * *$ \\
\hline
\end{tabular}

Different letters indicate significant differences among treatments by LSD test. *Significant at $P<$ 0.05 , **significant at $P<0.01, * * *$ significant at $P<0.005$, and non-significant (ns). 


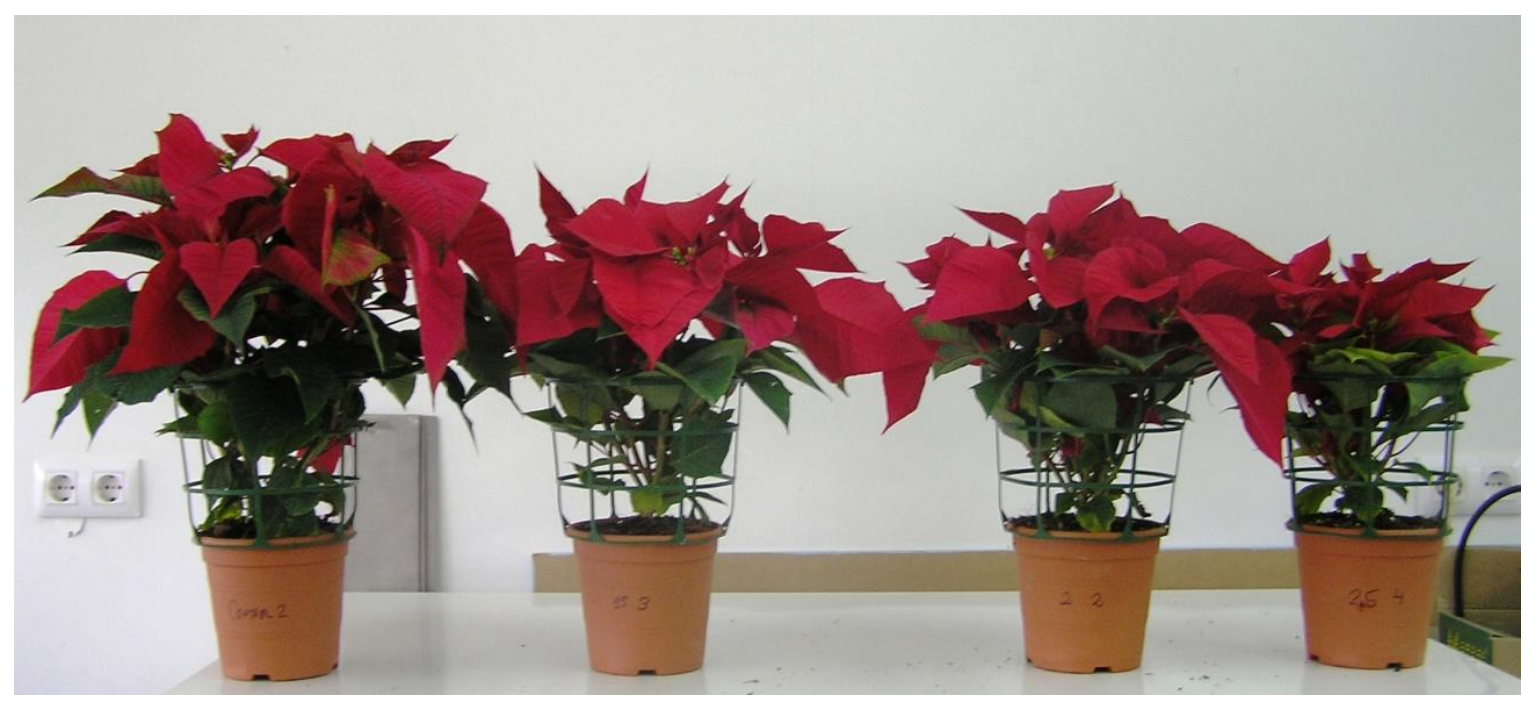

Picture 3. Poinsettia at the end of the experiment. From left to right control, saline irrigation with flushing when an $\mathrm{EC}_{\mathrm{B}}$ of $1.5 \mathrm{dS} \mathrm{m}{ }^{-1}$ was exceeded $\left(\mathrm{T}_{1.5}\right)$, saline irrigation with flushing when an $\mathrm{EC}_{\mathrm{B}}$ of $2 \mathrm{dS} \mathrm{m}^{-1}$ was exceeded $\left(\mathrm{T}_{2}\right)$ and saline irrigation with flushing when an $\mathrm{EC}_{\mathrm{B}}$ of $2.5 \mathrm{dS} \mathrm{m}^{-1}$ was exceeded $\left(\mathrm{T}_{2.5}\right)$.
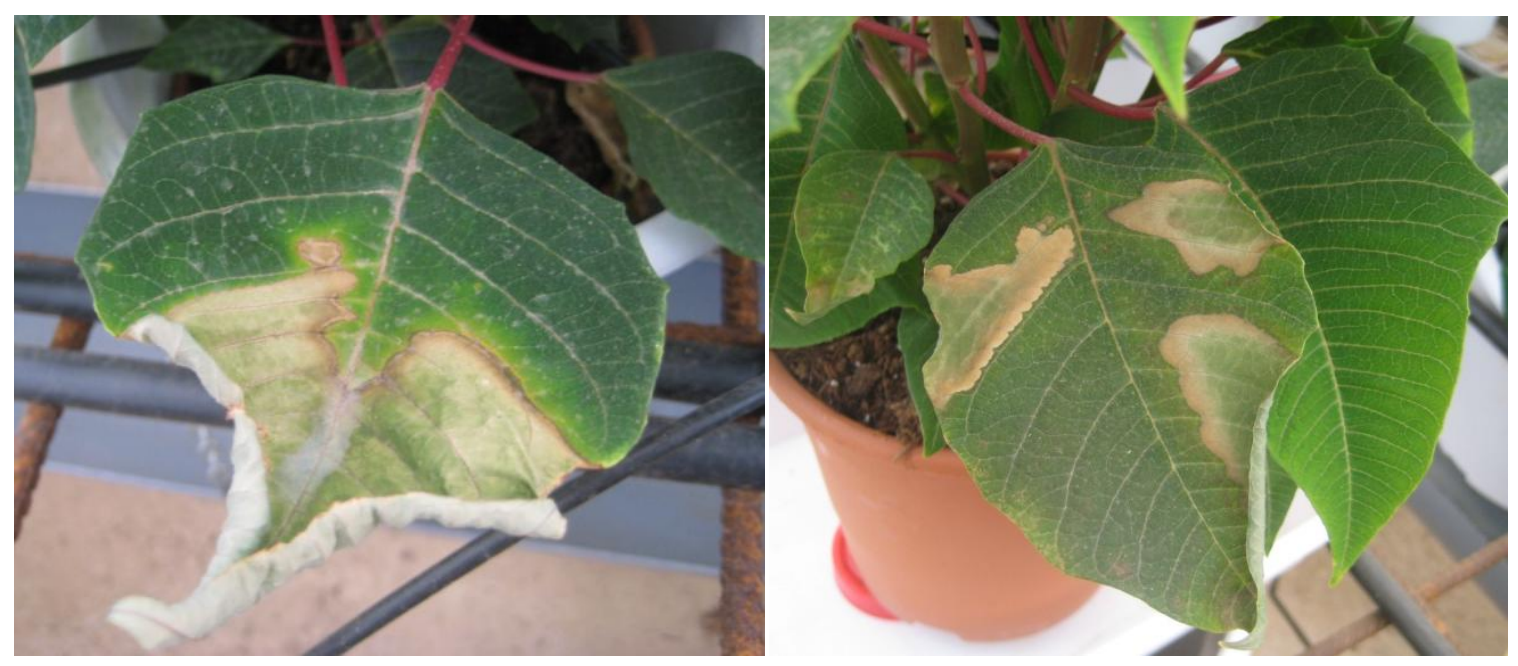

Picture 4. Damage in the basal leaves in $\mathrm{T}_{2.5}$. 


\subsection{Plant water status and gas exchange}

Leaf water potential $\left(\Psi_{1}\right)$ measured at midday was similar in all the salinated plants, while the control presented the lowest value (Table 2). However, the pressure potential $\left(\Psi_{\mathrm{p}}\right)$ differed between the saline treatments, with $T_{2.5}$ and $T_{2}$ showing higher values than $\mathrm{T}_{1.5}$. These differences were due to the osmotic potential $\left(\Psi_{\mathrm{o}}\right)$, which was lower in $T_{2}$ and $\mathrm{T}_{2.5}$ than in $\mathrm{T}_{1.5}$. The control plants had a higher $P_{\mathrm{n}}$ and $g_{\mathrm{s}}$ than the salinated plants. The three saline treatments produced similar values for $P_{\mathrm{n}}$, while $g_{\mathrm{s}}$ was lower in $\mathrm{T}_{2}$ and $\mathrm{T}_{2.5}$ than in $\mathrm{T}_{1.5}$ (Table 2).

Table 2. Water relations and gas exchange.

\begin{tabular}{|c|c|c|c|c|c|}
\hline \multirow{2}{*}{ Parameters } & \multicolumn{4}{|c|}{ Treatments } & \multirow{2}{*}{ Significance } \\
\hline & Control & $\mathrm{T}_{1.5}$ & $\mathrm{~T}_{2}$ & $\mathrm{~T}_{2.5}$ & \\
\hline$\Psi_{1}(\mathrm{MPa})$ & $-1.19 a$ & $-1.01 b$ & $-1.12 b$ & $-1.00 \mathrm{~b}$ & $*$ \\
\hline$\Psi_{\mathrm{p}}(\mathrm{MPa})$ & $0.13 \mathrm{a}$ & $0.38 b$ & $0.42 \mathrm{c}$ & $0.48 \mathrm{c}$ & $* *$ \\
\hline$\Psi_{\mathrm{o}}(\mathrm{MPa})$ & $-1.32 b$ & $-1.39 b$ & $-1.54 \mathrm{a}$ & $-1.48 \mathrm{a}$ & $* * *$ \\
\hline$P_{\mathrm{n}}\left(\mu \operatorname{molm}^{-2} \mathrm{~s}^{-1}\right)$ & $10.40 \mathrm{~b}$ & $6.30 \mathrm{a}$ & $6.10 \mathrm{a}$ & $6.05 a$ & $* * *$ \\
\hline$g_{\mathrm{s}}\left(\mathrm{mmol} \mathrm{m} \mathrm{m}^{-2} \mathrm{~s}^{-1}\right)$ & $91.00 \mathrm{c}$ & $46.00 \mathrm{~b}$ & $31.50 \mathrm{a}$ & $37.25 \mathrm{a}$ & $* * *$ \\
\hline
\end{tabular}

Different letters indicate significant differences among treatments by LSD test. *Significant at $P<$ 0.05 , **significant at $P<0.01, * * *$ significant at $P<0.005$, and non-significant (ns).

\subsection{Evapotranspiration}

Figure 1 shows how, after two weeks' cultivation ( 9 October), the pots of the $T_{2.5}$ treatment had lost less water than the other treatments. Differences in evapotranspiration (ET) between $T_{1.5}$ and $T_{2}$ treatments and the control began to be evident after three weeks (20 October), and, after four weeks (26 October), the ET in $T_{2}$ was below that of $T_{1.5}$. At the end of the cultivation time, the control had the highest accumulated ET; under saline irrigation conditions, the accumulated ET increased as the $\mathrm{EC}_{\mathrm{B}}$ threshold for flushing decreased. 


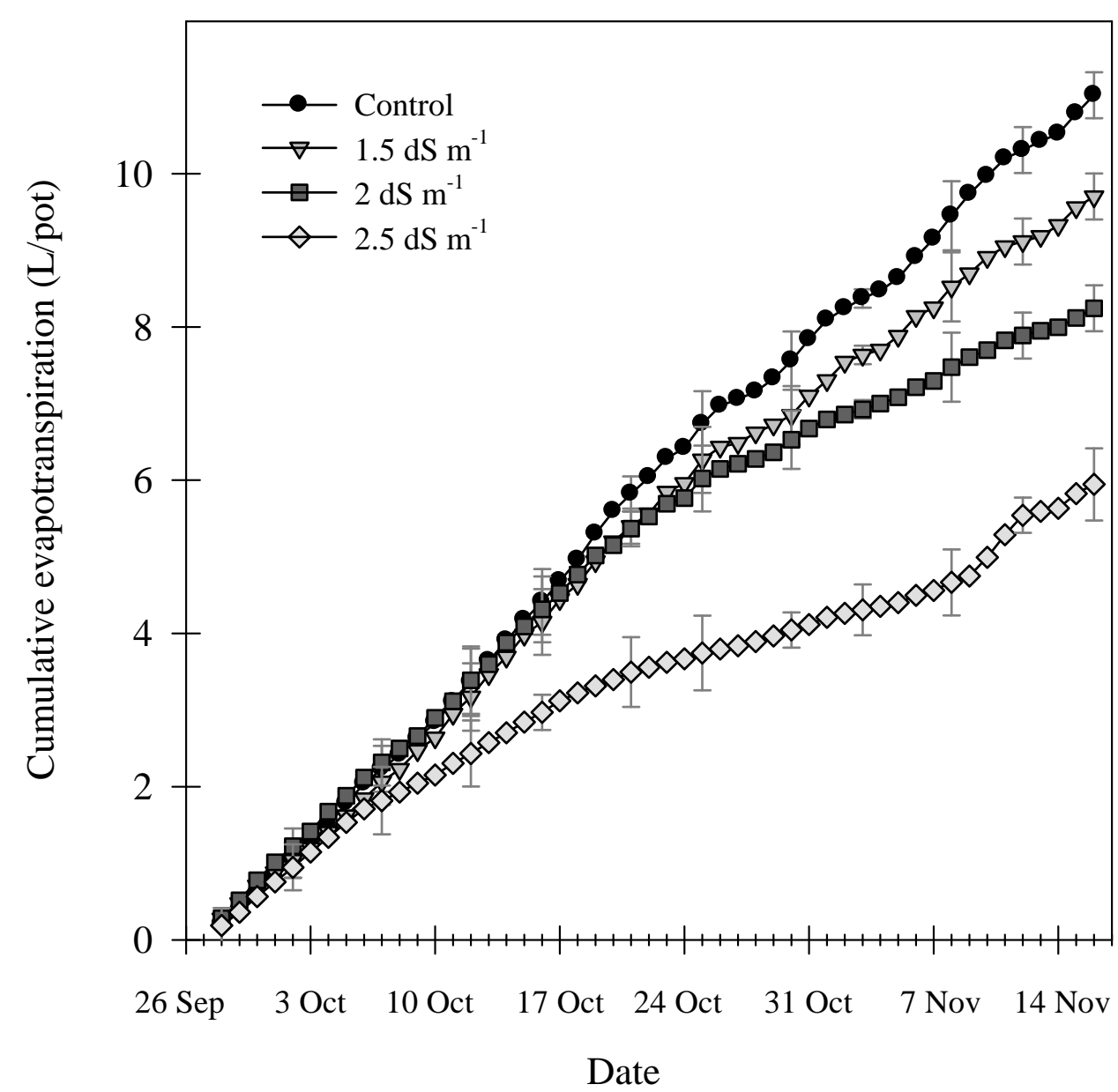

Figure 1. Daily evolution of accumulated evapotranspiration (ET) during the experiment. Vertical bars show LSD at $\mathrm{P}<0.05$.

\subsection{Applied water, number of irrigations, leaching fraction and IWUE}

Plants in the $\mathrm{T}_{1.5}$ treatment received the most water (25\% more than the controls) and plants in the $T_{2.5}$ received the least water (42\% less than the controls) (Table 3 ). The control was irrigated most frequently, and each one of the irrigation events can be considered as leaching. The $\mathrm{T}_{1.5}$ and $\mathrm{T}_{2}$ had 19 and 15 flushing events, respectively. The control produced the lowest leaching fraction (26\%). In the saline treatments, the leaching fraction increased as the $\mathrm{EC}_{\mathrm{B}}$ threshold fixed for flushing decreased $\left(\mathrm{T}_{1.5}\right.$ produced the highest leaching fraction). Salinity clearly reduced IWUE and, of the different saline treatments, $\mathrm{T}_{2.5}$ reduced it least. 
Table 3. Applied water, irrigating, leaching, IWUE and EC.

\begin{tabular}{|c|c|c|c|c|c|}
\hline \multirow{2}{*}{ Parameters } & \multicolumn{4}{|c|}{ Treatments } & \multirow{2}{*}{ Signification } \\
\hline & Control & $\mathrm{T}_{1.5}$ & $\mathrm{~T}_{2}$ & $\mathrm{~T}_{2.5}$ & \\
\hline Applied water (L/pot) & 14.89 & 18.70 & 14.77 & 8.57 & - \\
\hline Number of irrigation and flushing events & 34 & 23 & 22 & 19 & - \\
\hline Number of irrigation events & 34 & 4 & 7 & 18 & - \\
\hline Number of flushing events & 0 & 19 & 15 & 1 & - \\
\hline Leaching fraction $(\%)$ & 25.96 & 48.11 & 44.19 & 30.12 & - \\
\hline IWUE $\left(\mathrm{g} \mathrm{DW} \mathrm{L}^{-1}\right)$ & $2.24 \mathrm{c}$ & $1.31 \mathrm{a}$ & $1.28 \mathrm{a}$ & $1.75 b$ & $* *$ \\
\hline Average $\mathrm{EC}_{\mathrm{BAI}}\left(\mathrm{dS} \mathrm{m} \mathrm{m}^{-1}\right)$ & $0.93 \mathrm{a}$ & $1.94 b$ & $2.16 \mathrm{c}$ & $2.09 \mathrm{bc}$ & $*$ \\
\hline Average leachate EC $\left(\mathrm{dS} \mathrm{m}^{-1}\right)$ & $3.38 \mathrm{a}$ & $8.04 d$ & $9.43 c$ & $7.65 b$ & $* *$ \\
\hline
\end{tabular}

Different letters indicate significant differences among treatments by LSD test.* Significant at $P<$ 0.05 , **significant at $P<0.01$

\subsection{Electrical conductivities}

The average $\mathrm{EC}_{\mathrm{BAI}}$ in controls was $0.93 \mathrm{dS} \mathrm{m}^{-1}$ (Table 3), which was accompanied by an average $\mathrm{EC}_{\mathrm{L}}$ of $3.38 \mathrm{dS} \mathrm{m}^{-1}$. These values may be associated with the absence of stress because plants were irrigated with fresh (non-saline) water. The saline treatments produced higher $\mathrm{EC}_{\mathrm{BAI}}$ and $\mathrm{EC}_{\mathrm{L}}$ values than the control, the latter values being statistically different between all three treatments.

A study of how $\mathrm{EC}_{\mathrm{BAI}}$ behaved after each irrigation event (Fig. 2) shows how the control registered around $1 \mathrm{dS} \mathrm{m}^{-1}$, with two peaks at the beginning (6 October) and end (11 November) of the experiment. As regards the saline treatments, the $\mathrm{EC}_{\mathrm{BAI}}$ values in $\mathrm{T}_{2}$ were higher than those in $\mathrm{T}_{1.5}$ until 6 October, while $\mathrm{T}_{2.5}$ showed intermediate values. For this reason, the first flushing event occurred in $\mathrm{T}_{2}\left(3\right.$ October), after which the $\mathrm{EC}_{\mathrm{BAI}}$ of the following event increased to around $2.6 \mathrm{dS} \mathrm{m}^{-1}$. Similar behaviour was seen in $\mathrm{T}_{1.5}$, and, after the first flushing event (5 October), all the following events were flushing, too, because the $\mathrm{EC}_{\mathrm{BAI}}$ values were closer to 2 than $1.5 \mathrm{dS} \mathrm{m}^{-1}$ (Fig. 2). In $\mathrm{T}_{2}$, after the first flushing event, all the following events, except three, were flushing, the first on 27 October, which produced a sharp increase in the $\mathrm{EC}_{\mathrm{BAI}}$ (close to $3 \mathrm{dS} \mathrm{m}^{-1}$ ), and on 3 and 10 November. In contrast with these two treatments, $T_{2.5}$ only produced one flushing event 
(at the end of the experiment) and the corresponding $\mathrm{EC}_{\mathrm{BAI}}$ values seemed to lie between those of the other two treatments.

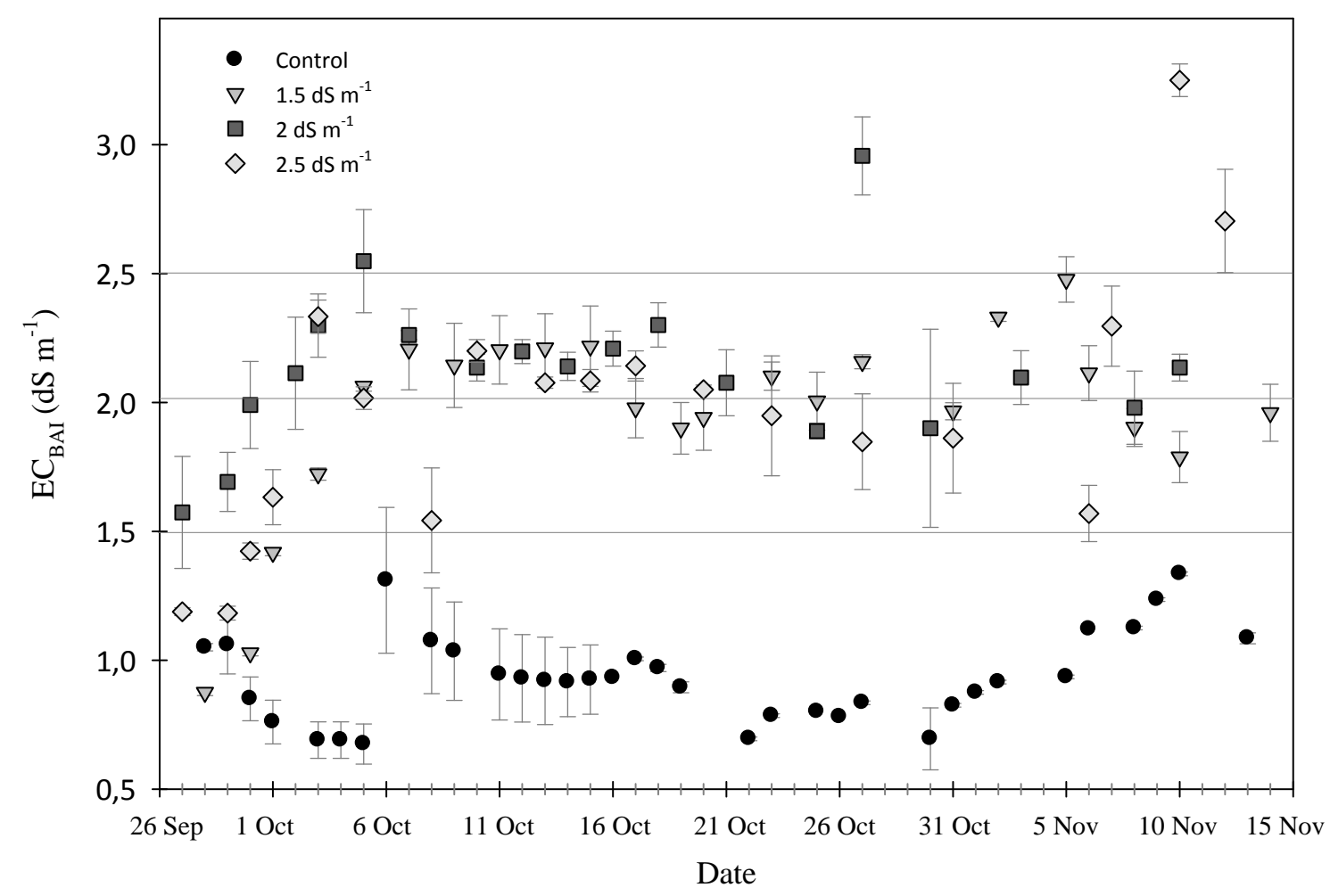

Figure 2. Evolution of bulk $\mathrm{EC}$ after irrigation finished $\left(\mathrm{EC}_{\mathrm{BAI}}\right)$ during the experiment. $\mathrm{The} \mathrm{EC}_{\mathrm{B}}$ values shown refer to the mean of the ten values recorded $30 \mathrm{~min}$ after irrigation or flushing finished. Vertical bars show LSD at $\mathrm{P}<0.05$. Horizontal lines mark the three ECB thresholds fixed for flushing.

\section{Discussion}

The control plants developed a larger total leaf area and showed better physiological activity than the salinated plants, which led to a higher accumulated ET during the experiment. However, $\mathrm{T}_{1.5}$ consumed the highest amount of water because it caused the most flushing irrigation. Besides the flushing events, leaf development also contributed to increased water consumption since a lower foliar area would have led to less transpiration and, consequently, lower water demand (Pinhero et al., 1997). The level of gas exchange also influences the amount of water consumed (Lorenzo et al., 1996), and the values of $g_{\mathrm{s}}$ recorded mean that the $T_{1.5}$ plants were slightly more active than $T_{2.5}$ and $T_{2}$ plants. This 
need for flushing in $\mathrm{T}_{1.5}$ meant that it was not easy to maintain the $\mathrm{EC}_{\mathrm{BAI}}$ of $1.5 \mathrm{dS} \mathrm{m}^{-1}$ with the water available. In contrast, $\mathrm{T}_{2.5}$ consumed less water because there was only one flushing event, the plants developed fewer leaves and because the physiological state of the plants was poor (hence the lowest accumulated ET). This one flushing event occurred at the end of the experiment, indicating that it was difficult to reach $2.5 \mathrm{dS} \mathrm{m}^{-1}$, despite the fact that the water had an EC of $4.5 \mathrm{dS} \mathrm{m}^{-1}$. However, $2 \mathrm{dS} \mathrm{m}^{-1}$ was reached easily, leading to 15 flushings in 22 irrigation events and a water consumption level close to that of the control.

IWUE reflects the relation between the biomass generated and the water used to generate the same. Of the saline treatments, $T_{2.5}$ reduced the IWUE least because the amount of water consumed was very low. Karlberg et al. (2006) suggested that WUE would be lower in saline conditions because plants would use photosynthesis products to counter the negative effects of salinity due to ion toxicity.

The salt tolerance of ornamental plants is usually determined from the reduction in growth of the whole plant or of specific parts. For example, the aerial part DW has frequently been used as a measure of salt tolerance - the lower the reduction in DW, the greater the tolerance to salt stress (Sánchez-Blanco et al., 1991; Álvarez et al., 2009). In our case, the DW values showed that the salt stress of plants increased as the $\mathrm{EC}_{\mathrm{B}}$ that triggers flushing increased. The same conclusion was reached for the total leaf area of the salinated plants - a diminution in foliar area is a response to water stress since it reduces the area for transpiration in many species, as has been observed, for example, in Nerium oleander (Bañón et al., 2005) and Gaura lindheimeri (Burnett and van Iersel, 2008). A reduction in cell elongation and division reduces the final size of leaves and hence overall foliar area (Alarcón et al., 1993). Although we did not determine the root DW due to the difficulty in separating the roots from the substrate, the growth index studied in this experiment (RGI) gives a good idea of root growth. The lower RGI observed in treatments $\mathrm{T}_{2}$ and $\mathrm{T}_{2.5}$ may reflect worse saline conditions than in $\mathrm{T}_{1.5}$ because salinity can inhibit root growth, leading to a reduction in root length and mass (Shannon and Grieve, 1999).

The assessment of salt tolerance for ornamental plants should be based primarily on their aesthetic value, because high salinity in the irrigation water may adversely affect their appearance by causing leaf damage such as burning or chlorosis (Bañón et al., 2011). $\mathrm{T}_{2}$ and $\mathrm{T}_{2.5}$ reduced the aesthetic value of the poinsettia plants as a consequence of strongly reduced leaf area (green and red) and the presence of damaged basal leaves, 
which did not occur in $\mathrm{T}_{1.5}$. Chlorosis in green leaves was assessed by measuring SPAD, which is an indicator of the relative content of chlorophylls and, therefore of leaf greenness (Monge and Bugbee, 1992). The leaves of $T_{2.5}$ plants showed a greater degree of chlorophyll degradation (lower SPAD). Niu et al. (2007) observed a significant reduction in SPAD values in the leaves of different herbaceous species as the severity of saline stress increased.

The physiological state of the plants at the end of the experiment was assessed by reference to the water status, accumulated ET and gas exchange. The values recorded for $\Psi_{1}$ showed that all the salinated plants had a good water status, better even than the control plants (higher $\Psi_{\mathrm{p}}$ ), which would explain the absence of wilting in the same. Such behaviour might be related with the fact that all the plants irrigated with saline water showed osmotic adjustment (increased $\Psi_{\mathrm{o}}$ ), thus increasing turgor. Navarro et al. (2008) found that plants of Arbutus unedo developed osmotic adjustment to maintain turgor. The treatments involving the highest saline stress $\left(\mathrm{T}_{2}\right.$ and $\left.\mathrm{T}_{2.5}\right)$ produced the most turgid plants. Figure 1 shows the evolution of ET rate in all treatments during the experimental period. The control plants presented the highest accumulated ET during the experiment, because they developed a larger total foliar area and showed better physiological activity than the salinated plants. Differences in ET between controls and the $\mathrm{T}_{2.5}$ treatment occurred earlier in the experiment $(\sim 15 \mathrm{Oct})$ than differences between controls and the $\mathrm{T}_{2}(\sim 31 \mathrm{Oct})$ and $\mathrm{T}_{1.5}(\sim 07$ Nov $)$ treatments. A decrease in accumulated ET has been related to plants exposed to adverse saline conditions (Tattini et al., 2002). These differences in ET at the end of the experiment can mainly be explained not only by the foliar area, but also by the level of gas exchange. The values of $g_{\mathrm{s}}$ recorded in the saline treatments showed that $\mathrm{T}_{1.5}$ plants had higher gas exchange, although the photosynthesis rates were similar in all three treatments. This fact could be related to greater the water availability of $T_{1.5}$ due to less salt being accumulated in the substrate and greater root development. On other hand, the similarity in $P_{\mathrm{n}}$ could be related to salinity damage, which produced alterations in some metabolites and damage in thylakoids, which could affect the transport of photosynthetic electrons (Pereira et al. 2000), because the gas exchange measurements were taken at the end of the experiment. Whatever the case, the differences in $g_{\mathrm{s}}$ between $\mathrm{T}_{1.5}$ and the rest of the saline treatments were slight and may not have been reflected in the photosynthesis rate. 
The mean $\mathrm{EC}_{\mathrm{BAI}}$ measurements differed from those corresponding to the threshold values fixed for the saline treatments. The values of $\mathrm{EC}_{\mathrm{BAI}}$ in $\mathrm{T}_{1.5}$ plants were closer to 2 $\mathrm{dS} \mathrm{m}^{-1}$, meaning that the flushing was did not serve to lower $\mathrm{EC}_{\mathrm{BAI}}$ even though the leaching fraction was approximately $50 \%$, which can be explained by the fact that EC bulk increases as $\theta$ and water salinity increase. Moreover, the greater the salinity of the substrate solution, the greater the influence of moisture on $\mathrm{EC}_{\mathrm{B}}$ (Amente et al., 2000). For this reason, the flushing action of $\mathrm{T}_{1.5}$ led to an average $\mathrm{EC}_{\mathrm{BAI}}$ value of $1.94 \mathrm{dS} \mathrm{m}^{-1}$, indicating that even repeated flushing with water of $4.5 \mathrm{dS} \mathrm{m}^{-1}$ will not lower the value any further. The average values of $\mathrm{EC}_{\mathrm{BAI}}$ and $\mathrm{EC}_{\mathrm{L}}$ in $\mathrm{T}_{2}$ were slightly higher than those of $\mathrm{T}_{1.5}$, indicating that the plants of treatment $\mathrm{T}_{1.5}$ grew in less saline conditions than those of $\mathrm{T}_{2}$ (Table 3). The treatment with the highest $\mathrm{EC}_{\mathrm{B}}$ threshold $\left(\mathrm{T}_{2.5}\right)$ produced an average value of $\mathrm{EC}_{\mathrm{BAI}}$ that was statistically similar to that of the other two saline treatments, while $\mathrm{EC}_{\mathrm{L}}$ was the lowest. This could mean that $\mathrm{T}_{2.5}$ did not produce worse saline conditions in the substrate than $\mathrm{T}_{2}$ and $\mathrm{T}_{1.5}$; however, the morphological and physiological data suggested the contrary.

The behavior of $\mathrm{EC}_{\mathrm{BAI}}$ in $\mathrm{T}_{2.5}$ can perhaps be explained by two observations: 1) the difficulty in reaching an $\mathrm{EC}_{\mathrm{BAI}}$ of $2.5 \mathrm{dS} \mathrm{m}^{-1}$, and 2) the irregular distribution of the substrate moisture. In the first case, unlike in $\mathrm{T}_{1.5}$, a high accumulation of salts near the probe was probably needed, a state that was only reached at the end of experiment when the flushing irrigation started. In the second case, the lower number of irrigation events and the lack of flushing may have led to the substrate drying in a more irregular way than in the other treatments. The way in which irrigation is carried out influences salt distribution in the substrate (De Rijck and Schrevens, 1998), and the presence of salt may lead to the irregular growth of roots since they will tend to avoid the areas outside the influence of the emitter (Morvant et al., 1997; Ondrasek et al., 2008 and Valdés et al., 2014), which was, in our experiment, where the sensors were sited. Consequently, when the sensor detects that the $\theta$ threshold that controls the irrigation has been reached other parts of the substrate will be drier, which may affect rehydration when irrigation occurs. In addition, the HPII probe probably overestimates the $\theta$ in conditions of high salinity and humidity (Valdés et al., 2012), preventing an increase in $\mathrm{EC}_{\mathrm{B}}$ due to the lower moisture of the substrate, which would affect the HPII $\mathrm{EC}_{\mathrm{B}}$ readings. The low $\mathrm{EC}_{\mathrm{L}}$ in $\mathrm{T}_{2.5}$ indicates that this treatment leached a low amount of salts, which is related with the second point when irrigation occurred, the water was not homogenously distributed, so any drainage 
would have come only from a portion of the substrate. This could be related with the irrigation technique used, and more drippers per pot could improve the homogeneity of water distribution in substrate (Valdés et al., 2014).

\section{Conclusions}

The great influence of substrate humidity on $\mathrm{EC}_{\mathrm{B}}$ meant that average $\mathrm{EC}_{\mathrm{BAI}}$ did not differ much between the saline treatments applied, so this EC cannot be considered to accurately reflect substrate salinity. To minimize the effect of humidity on $\mathrm{EC}_{\mathrm{B}}$, measurements should be made in the saturated substrate (maintaining it more or less homogeneously moist), because $\mathrm{EC}_{\mathrm{B}}$ falls with decreasing humidity, although real salinity remains the same. Despite this, the three $\mathrm{EC}_{\mathrm{BAI}}$ thresholds studied produced different effects on plant growth, suggesting that this parameter is closely related with salinity. So, determining the $\mathrm{EC}_{\mathrm{BAI}}$ may be a useful tool for mitigating the negative effects of saline irrigation in the production of potted ornamental plants. We suggest that $\mathrm{EC}_{\mathrm{BAI}}$ thresholds of between 1.3 and $1.7 \mathrm{dS} \mathrm{m}^{-1}$ would be more suitable than those studied in this experiment.

\section{Acknowledgements}

We are grateful for the financial aid received from the Ministerio de Economía y Competitividad and FEDER through the projects (AGL2011-30022-C02-1 and AGL201130022-C02-2) and SENECA project (08669/PI/08).

\section{References}

Alarcón, J.J., Sánchez-Blanco, M.J., Bolarin, M.C., Torrecillas, A., 1993. Water relations and osmotic adjustment in Lycopersicon esculentum and L. pennelli during short-term salt exposure and recovery. Physiol. Plant. 89, 441-447.

Álvarez, S., Navarro, A., Bañón, S., Sánchez-Blanco, M.J., 2009. Regulated deficit irrigation in potted Dianthus plants: Effects of severe and moderate water stress on growth and physiological responses. Sci. Hortic. 122, 579-585. 
Amente, G., Baker, J.M., Reece, C.F., 2000. Estimation of Soil Solution Electrical Conductivity from Bulk Soil Electrical Conductivity in Sandy Soils. Soil Sci. Soc. Am. J. 64, 1931-1939.

Azza, A.M., Fatma, E.M., Farahat, M.M., 2007. Responses of ornamental plants and woody trees to salinity. World J. Agric. Sci. 3, 386-395.

Bañón, S., Fernández, J.A., Ochoa, J., Blanco, M.J., 2005. Paclobutrazol as an aid to reduce some effects of salt stress in oleander seedlings. Eur. J. Hortic. Sci. 70, 43-49.

Bañón, S., Miralles, J., Franco, J.A., Ochoa, R., Sánchez-Blanco, M.J., 2011. Effects of diluted and pure treated wastewater on the growth, physiological status and visual quality of potted lantana and polygala plants. Sci. Hortic. 129, 869-876.

Bittelli, M., 2011. Measuring Soil Water Content: A Review. HortTechnology 21, 293 300.

Burnett, S.E., van Iersel, M., 2008. Morphology and irrigation efficiency of Gaura lindheimeri grown with capacitance sensor-controlled irrigation. HortScience 43, 1555-1560.

Campbell, J.E., 2002. Salinity effects in capacitive soil moisture measurement. Pap. no. 1.2. In I.C. Paltineau (ed.) Trans. Int. Symp. on Soil Water Measurement Using Capacitance and Impedance, 1st, Beltsville, MD. 5-7 Nov. 2002. PALTIN Int., Laurel, MD.

Cavins, J.T., Whipker, B.E., Fonteno, W.C., Harden, B., McCall, I., Gibson, J.L., 2000. Monitoring and Managing $\mathrm{pH}$ and EC Using the PourThru Extraction Method. North Carolina State University Horticulture. Information Leaflet. 590, pp 17.

De Rijck, G., Schrevens, E., 1998. Distribution of nutrients and water in rockwool slabs. Sci. Hort. 72, 277-285.

Ecke, P., Williams. J., Faust, J.E., Higgins, A., 2004. The Ecke Poinsettia Manual. Ball Publishing. Batavia, Illinois, USA, pp. 287.

Hilhorst, M.A., 2000. A pore water conductivity sensor. Soil Sci. Soc. Am. J. 64, 19221925.

Incrocci, L., Incrocci, G., Pardossi, A., Lock G., Nicholl, C., Balendonck, J., 2009. The Calibration of WET-Sensor for Volumetric Water Content and Pore Water Electrical Conductivity in different Horticultural Substrates. Acta Hortic. 807, 289-294.

Karlberg, L., Ben-Gal, A., Jansson, P.E., Shani, U., 2006. Modelling transpiration and growth in salinity-stressed tomato under different climatic conditions. Ecol. Model. 190, 15-40. 
Lorenzo, P., Medrano, E., Sánchez-Guerrero, M.C., Muñoz, R., 1996. Greenhouse crop transpiration, an implement to soilless irrigation management. Acta Hortic. 458, 113119.

Malicki, M.A., Walczak, R.T., 1999. Evaluating soil salinity status from bulk electrical conductivity and permittivity. Eur. J. Soil Sci. 50, 505-514.

Monge, O.A., Bugbee, B., 1992. Inherent limitations of nondestructive chlorophyll meters: a comparison of two types of meters. HortScience 27, 69-71.

Morvant, J.K., J.M. Dole, and E. Allen. 1997. Irrigation systems alter distribution of roots, soluble salts, nitrogen, and $\mathrm{pH}$ in the root medium. HortTechnology 7:156-160.

Muñoz-Carpena, R., Regalado, C.M., Alvarez-Benedí, J., Socorro, A.R., Pérez, N., 2001. Determinación simultánea mediante TDR del transporte de agua y un soluto salino en el suelo, p.1-7. In: López, J. J., Quemada, M. (eds.). Temas de investigación en zona no saturada. Universidad Pública de Navarra, Pamplona, p. 1-7.

Navarro, A., Bañón, S., Conejero, W., Sánchez-Blanco, M.J., 2008. Ornamental characters, ion accumulation and water status in Arbutus unedo seedlings irrigated with saline water and subsequent relief and transplanting. Environ. Exp. Bot. 66, 362371.

Nemali, K., van Iersel, M., 2006. An automated system for controlling drought stress and irrigation in potted plants. Sci. Hortic. 110, 292-297.

Niu, G., Rodriguez, D.S., Aguiniga, L., 2007. Growth and landscape performance of ten herbaceous species in response to saline water irrigation. J. Environ. Hortic. 25, 204210.

Ondrasek, G., Romic, D. Romic, M. Tomic, F. Mustac, I., 2008. Salt distribution in peat substrate grown with melon (Cucumis melo L.). Acta Hort. 779, 307-312.

Pereira, W.E., De Siqueira, D.L., Martínez, C.A., Puiatti, M., 2000. Gas exchange, chlorophyll fluorescence in four citrus rootstocks under aluminum stress. J. Plant Physiol. 157, 513-520.

Pinhero, R.G., Rao, M., Paliyath, G., Murr, D., Fletcher, R., 1997. Changes in activities of antioxidant enzymes and their relationship to genetic and paclobutrazol induced chilling tolerance of maize seedlings. Plant Physiol. 114, 695-704.

Regalado, C.M., Ritter, A., Rosa M., Rodríguez-González, R.M., 2007. Performance of the Commercial WET Capacitance Sensor as Compared with Time Domain Reflectometry in Volcanic Soils. Vadose Zone J. 6, 244-254. 
Rhoades, J.D., Shouse, P.J., Alves, W.J., Manteghi, N.A., Lesch, S.M., 1990. Determining Soil Salinity from Soil Electrical Conductivity using Different Models and Estimates. Soil Sci. Soc. Am. J. 54, 46-54.

Sánchez-Blanco, M.J., Bolarín, M.C., Morales, M.A., Alarcón, J.J., Torrecillas, A., 1991. Salinity effect on water relations in Lycopersicum esculentum and its wild salttolerance relative species, L. pennellii. Physiol. Plant. 83, 269-274.

Seyfried, M.S., Murdock, M.D., 2004. Measurement of soil water content with a $50 \mathrm{MHz}$ soil dielectric sensor. Soil Sci. Soc. Am. J. 68, 394-403.

Shannon, M.C., Grieve, C.M., 1999. Tolerance of vegetable crops to salinity. Sci. Hortic. $78,5-38$.

Tattini, M., Montagni, G., Traversi, M.L., 2002. Gas exchange, water relations and osmotic adjustment in Phillyrea latifolia grown at various salinity concentrations. Tree Physiol. 22, 403-412.

Valdés, R., Miralles, J., Ochoa, J., Franco, J.A., Sánchez-Blanco, M.J., Bañón, S., 2012. Prueba de sondas para medir conductividad y humedad del sustrato en maceta en condiciones salinas. Actas del XI Simposio Hispano-Portugués de Relaciones Hídricas en las Plantas, 222-225.

Valdés, R., Miralles, J., Ochoa, J., Sánchez-Blanco, M.J., and Bañón, S., 2014.The number of emitters alters salt distribution and root growth in potted gerbera. HortScience 49, 160-165.

Wu, L., Dodge, L., 2005. A special report for the Elvenia J. Slosson Endowment Fund, Landscape salt tolerance selection guide for recycled water irrigation. University of California, Davis, CA. Available in http://slosson.ucdavis.edu/files/66355.pdf [11 September 2010]. 


\section{Chapter 4}

\section{Relationships among electrical conductivities}

under salinizing irrigation for potted

\section{osteospermum}

R. Valdés ${ }^{1}$, J.A. Franco ${ }^{1}$, J. Ochoa ${ }^{1}$, M. J. Sánchez-Blanco ${ }^{2}$ and S. Bañón ${ }^{1,2}$

${ }^{1}$ Departamento de Producción Vegetal. Universidad Politécnica de Cartagena. Cartagena, Spain

${ }^{2}$ Centro de Edafología y Biología Aplicada del Segura-CSIC, Murcia, Spain 


\begin{abstract}
Potted osteospermum plants, grown in a greenhouse during winter, were irrigated with water of $1.5,2,2.5,3,3.5,4$ and $4.5 \mathrm{dS} \mathrm{m}^{-1}$ EC. Maintaining the same irrigation volume and frequency for all the EC values, the following relationships were studied: pore water $\mathrm{EC}\left(\mathrm{EC}_{\mathrm{PW}}\right)$ using the pour-through method $\left(\mathrm{EC}_{\mathrm{PW}} \mathrm{PT}\right)$ vs. $\mathrm{EC}_{\mathrm{PW}}$ estimated with the GS3 sensor $\left(\mathrm{EC}_{\mathrm{PW}} \mathrm{GS} 3\right), \mathrm{EC}_{\mathrm{PW}} \mathrm{PT}$ vs. bulk $\mathrm{EC}\left(\mathrm{EC}_{\mathrm{B}}\right), \mathrm{EC}_{\mathrm{PW}} \mathrm{PT}$ vs. leachate $\mathrm{EC}\left(\mathrm{EC}_{\mathrm{L}}\right)$ and $\mathrm{EC}_{\mathrm{PW}} \mathrm{GS} 3$ vs. $\mathrm{EC}_{\mathrm{B}}$ in order to improve the management of saline irrigation using soil moisture and EC sensors. The salinity tolerance of osteospermum was also determined. Increases in irrigation water $\mathrm{EC}\left(\mathrm{EC}_{\mathrm{IW}}\right)$ reduced plant height, diminished aerial dry biomass, and encouraged the natural presence of basal leaves with necrotic damage. The results highlight the moderate salinity tolerance of osteospermum, which is related to its capacity to accumulate chloride and sodium in leaves. Bulk EC was closely related with $\mathrm{EC}_{\mathrm{PW}} \mathrm{PT}$ and $\mathrm{EC}_{\mathrm{PW}} \mathrm{GS} 3$ (especially immediately after irrigation). $\mathrm{EC}_{\mathrm{PW}} \mathrm{GS} 3, \mathrm{EC}_{\mathrm{L}}$ and $\mathrm{EC}_{\mathrm{PW}} \mathrm{PT}$ increased as the $\mathrm{EC}_{\mathrm{IW}}$ increased. $\mathrm{EC}_{\mathrm{L}}$ was higher than $\mathrm{EC}_{\mathrm{PW}} \mathrm{PT}$, while the latter was higher than $\mathrm{EC}_{\mathrm{PW}} \mathrm{GS} 3$; thus, $\mathrm{EC}_{\mathrm{L}}$ overestimates $\mathrm{EC}_{\mathrm{PW}} \mathrm{PT}$, while $\mathrm{EC}_{\mathrm{PW}} \mathrm{GS} 3$ underestimates it. The estimation of $\mathrm{EC}_{\mathrm{PW}} \mathrm{GS} 3$ provided by the Hilhorst model was not very accurate due to the influence of salinity, humidity and temperature. The average $\mathrm{EC}_{\mathrm{PW}} \mathrm{GS} 3$ calculated between two irrigation events increases as the growth cycle advanced. The higher the $\mathrm{EC}_{\mathrm{IW}}$, the greater the variability in all the measurements made with the GS3.
\end{abstract}

Key words: salinity, soil probe, pour-through, ornamental plant, leachate

\title{
1. Introduction
}

Freshwater depletion is leading to the use of alternative water sources, including recycled wastewater and saline underground water, for irrigating nurseries, greenhouses and landscapes. This implies an urgent need to identify plant species that can grow with saline water and the development of more efficient irrigation water management systems. Some countries regulate the use of reclaimed waters in the case of nursery production and landscape irrigation (Tanji et al., 2008). However, reclaimed wastewater may contain high levels of salt and toxic ions, whose levels will depend on the location of the wastewater treatment plant (Bañón et al., 2011). The problem is that salt usually has an adverse effect on plant development, which may suffer slowed growth, damaged leaves and, in the 
severest cases, death. High salinity involves osmotic effects in plants, which must expend more energy to extract water from the soil as that water becomes more saline. Salinity may increase the concentration of ions that have an inhibitory effect on the plant metabolism, with sodium and chloride usually considered toxic to plants (Dudley, 1992; Hasegawa et. al., 2000). Competition and interaction between saline and nutrient ions in the substrate, as well as within the plant, frequently lead to ion imbalances that may result in nutrient deficiencies (Grieve and Shannon, 1999; Bayuelo-Jimenez et al., 2003).

Plants vary widely in their tolerance to salts, and the extent of any damage will depend on their salt sensitivity; indeed, many have developed a variety of physiological mechanisms to cope with the detrimental effects of salt stress, such as the control of ion uptake by roots and subsequent transport to leaves, the selective buildup or exclusion of salt ions and ion compartmentalization (Parida and Das, 2005). In the case of ornamental plants, salt tolerance is often assessed based on the growth of the whole plant or specific parts, such as roots, shoots, leaves and floral stems (Villarino and Mattson, 2011). Reductions in plant height, leaf area, the number of leaves and number of floral stems have been related with salinity sensitivity in many species (Franco et al., 1997). Reduced growth parameters and the presence of foliar damage, such as burning or chlorosis, strongly affect a plant's aesthetic value (Bañón et al., 2011).

Vegetative osteospermum (African daisy) cultivars have great potential for flower plant production, because they produce many attractive flowers and can form a dramatic display of color when planted in mass, blooming in early spring with a prolonged blooming time (Gibson and Whipker, 2003). This is why they have risen in popularity in the last fifteen years, becoming very popular as bedding plants, either in borders or in pots. Although osteospermum is considered moderately salt tolerant (Pasternak and Nerd, 1995) and drought resistant (Treder and Nowak, 2001), there have been very few scientific studies conducted to accurately gauge its degree of salt tolerance.

On the other hand, salt tolerance in plants must also regard in the light of irrigation management practices. Indeed, Oron et al. (2002) suggested saline water has an agricultural potential if combined with appropriate irrigation practices. While irrigation management involves deciding when plants should be irrigated and how much water should be applied, in the case of salinity we must measure how much salt is currently in the soil (by continuous monitoring), because irrigation water not only applies water to a crop, but may also apply salts, water-soluble fertilizer, or both. Electrical conductivity 
(EC) measurements are often used to identify and address soil salinity issues in irrigated cropping systems (Van Der Laan et al., 2011). Although the most accurate methods of determining soil salinity are laboratory-based tests (which determine pore water EC, typically after dilution), there has been significant progress made with in situ EC measurements. Such measurements usually include the EC of the combined substrate particles, air and solution (bulk EC), the $\mathrm{EC}$ of the pore water in the substrate $\left(\mathrm{EC}_{\mathrm{PW}}\right)$ and the $\mathrm{EC}$ of the leachate $\left(\mathrm{EC}_{\mathrm{L}}\right)$. Bulk $\mathrm{EC}\left(\mathrm{EC}_{\mathrm{B}}\right)$ has little practical value because it greatly depends of the soil water content (Scoggins and van Iersel, 2006; Amente et al., 2000), and is thus usually regarded as a poor indicator of the salinity present in the soil. However, $\mathrm{EC}_{\mathrm{B}}$ is the only EC measure that can be continuously monitored in situ by soil sensors such as the GS3-Decagon, and the availability of such soil moisture sensors that are also capable of monitoring $\mathrm{EC}_{\mathrm{B}}$ has opened new possibilities for the application of a saline water in horticultural crops, particularly in the case of container cultivation (Incrocci et al., 2010). In contrast, $\mathrm{EC}_{\mathrm{PW}}$ has a great influence on the growth and development of plants because this represents the EC in the water extracted by plants from the growth medium. On these issues, a considerable amount of research has been conducted to determine the relationship between $\mathrm{EC}_{\mathrm{PW}}$ and $\mathrm{EC}_{\mathrm{B}}$ (Kargas and Kerkides, 2012). One of the models put forward is that developed by Hilhorst (2000), which predicts $\mathrm{EC}_{\mathrm{PW}}$ using data of bulk dielectric permittivity $\left(\varepsilon_{\mathrm{B}}\right)$ and $\mathrm{EC}_{\mathrm{B}}$, as these are obtained by sensors. However, several factors, such as substrate moisture, temperature and salinity, may act to reduce the accuracy of this estimation (Rosenbaum et. al., 2011; Valdés et al., 2012). These last authors described how salinity may affect the $\varepsilon_{\mathrm{B}}$ readings of HPII-sensors, increasing data scatter and affecting the accuracy and reliability of the estimation of $\mathrm{EC}_{\mathrm{PW}}$. Valdés et al. (2014a) recently found that the Hilhorst model for calculating the average $\mathrm{EC}_{\mathrm{PW}}$ between two irrigation events was not very accurate in the presence of high salinity. While growers habitually record average $\mathrm{EC}_{\mathrm{L}}$ values from various pots in an irrigation zone (the leachate is easy to collect), $\mathrm{EC}_{\mathrm{L}}$ records rarely coincide with those of $\mathrm{EC}_{\mathrm{PW}}$, because $\mathrm{EC}_{\mathrm{L}}$ depends on factors such as the leaching fraction, irrigation water salinity, the physical characteristics of the substrate and environmental conditions ( $\mathrm{Ku}$ and Hershey, 1991, Torres et al, 2010). Another way of measuring $\mathrm{EC}_{\mathrm{PW}}$ on-site is the pour-through (PT) method, which was described by Wright (1986) and adapted by Cavins et al. (2008). Pourthrough extraction occurs by displacement of the root zone solution by distilled water poured over the top of a substrate as a means to obtain a soil solution sample. The PT 
method is a widely accepted practice for both nurseries and greenhouses (Torres et al., 2010).

The main aim of this study was evaluate the relationships between all these conductivities in potted osteospermum irrigated with water of different salinity levels, and, to a lesser extent, determine the growth, leaf damage and ion accumulation in plants. We think that these findings will be useful for improving saline irrigation management in potted plant production and for predicting response to salinity of osteospermum plants.

\section{Materials and methods}

\subsection{Plant material and crop conditions}

Osteospermum hybrid "Margarita Supreme Lilac" rooted cuttings were obtained from a commercial producer (Barbaret\&Blanc S.A., Puerto Lumbreras, Spain). The cuttings were transplanted the first week of October 2014 into 17-cm diameter, black pots of 2.8-L volume filled with a substrate containing (by volume) sphagnum peat (40\%), coconut fiber (40\%) and perlite (20\%) The experiment took place in a greenhouse with a semicircular cover (12 m long $\cdot 7 \mathrm{~m}$ wide, and $3 \mathrm{~m}$ high at the side and $4.5 \mathrm{~m}$ at the center) located at the Agricultural Experimental Station of the Polytechnic University of Cartagena $\left(37^{\circ} 35^{\prime} \mathrm{N}, 0^{\circ} 59^{\prime} \mathrm{W}\right)$. The roof was covered with polyethylene film and a green shading screen $(50 \%$ shade). The sides were covered with antiaphid mesh and polyethylene film, which could be rolled up for ventilation. The front and the back were covered with antiaphid mesh. The pots were introduced into white pots $(24 \mathrm{~cm}$ diameter) kept in place in holes $(21 \mathrm{~cm} \cdot 21 \mathrm{~cm})$ on a metal grid made of corrugated bars $(8 \mathrm{~mm}$ diameter), $80 \mathrm{~cm}$ off the ground (Picture 1).

A LOG32 data logger (Dostmann electronic GmbH. Wertheim-Reicholzheim, Germany) was used to measure and record air temperature and humidity every $30 \mathrm{~min}$ during the experimental period. The weather conditions were: $7.84 \pm 2.6{ }^{\circ} \mathrm{C}$ (minimum) and $26.80 \pm 3.90{ }^{\circ} \mathrm{C}$ (maximum); relative humidity 38.83 $\pm 16.60 \%$ (minimum) and 76.58 \pm 9.30 $\%$ (maximum). Photosynthetic active radiation was measured with a quantum sensor (SQ110; Apogee Instruments, Logan, UT), and the daily light integral was calculated, giving $5.59 \pm 1.36 \mathrm{~mol} \mathrm{~m}^{-2} \mathrm{~d}^{-1}$. 


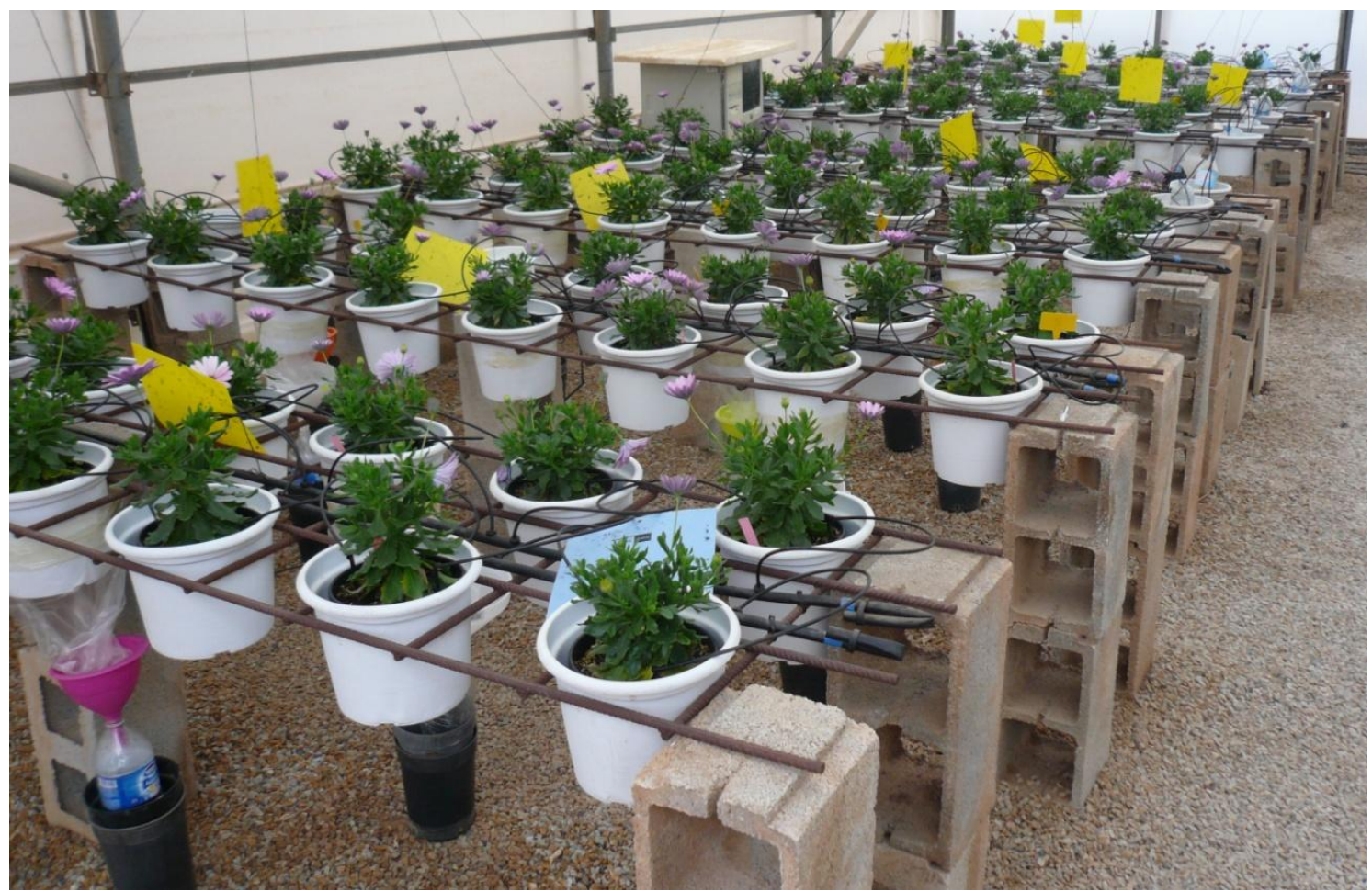

Picture 1. An overview of the greenhouse, which shows tables for different treatments and leachate collection system.

\subsection{Irrigation treatments}

The treatments were used eight irrigation solutions of increasing $\mathrm{EC}_{\mathrm{IW}}(1.5,2,2.5,3$, $3.5,4,4.5$ and $5 \mathrm{dS} \mathrm{m}^{-1}$ ) achieved by adding sodium chloride plus nutrients to the irrigation water. Fertilizers were provided in the water at constant concentrations: $80 \mathrm{~N}-40$ $\mathrm{P}_{2} \mathrm{O}_{5}-80 \mathrm{~K}_{2} \mathrm{O}(\mathrm{ppm})$ with a $\mathrm{pH}$ of 6 . This nutrient solution was made by mixing $\mathrm{KNO}_{3}$, $\mathrm{NH}_{4} \mathrm{NO}_{3}, \mathrm{KH}_{2} \mathrm{PO}_{4}$ and $\mathrm{HNO}_{3}$, increasing the $\mathrm{EC}$ by $0.5 \mathrm{dS} \mathrm{m}{ }^{-1}$. The application of saline irrigations began on 17 November 2013 (after five weeks growing period without salt) and finished on 6 February 2014.

Each pot had two emitters (Netafim Ltd. Corporate Headquarters, Tel Aviv, Israel) providing $1.2 \mathrm{~L} \mathrm{~h}^{-1}$ connected to a spaghetti tube $(60 \mathrm{~cm} \cdot 4 \mathrm{~mm})$ and were inserted into the substrate by means of a straight plastic arrow. The irrigation provided was controlled using dielectric sensors (GS3, Decagon Devices Inc., Pullman, WA) connected to a data logger (CR1000, Campbell Scientific Inc., Logan, UT) with a 16-channel relay controller SMD-CD16D (Campbell Scientic Inc., Logan, UT) to operate the solenoid valves of the eight 250-L tanks containing the irrigation solutions (one solenoid valve and relay per tank). 
The GS3 sensor simultaneously measures temperature, $\mathrm{EC}_{\mathrm{B}}$ and $\varepsilon_{\mathrm{B}}$ in the same soil volume. Three sensors per treatment (fully inserted into the substrate) were placed vertically in the east-facing part of the substrate (between the two emitters in the pot).

The CR1000 was programmed to collect GS3 outputs every minute and thirty minutes averages were recorded. The data logger converts $\varepsilon_{\mathrm{B}}$ from the GS3 to volumetric water content $(\theta)$ based on a substrate-specific calibration $(\theta=-0.0001$ $\left.\varepsilon_{\mathrm{B}}{ }^{2}+0.0168 \varepsilon_{\mathrm{B}}+0.0356, \mathrm{r}^{2}=0.97\right)$ using the procedure described by Valdés et al. (2012). The CR1000 determined the $\mathrm{EC}_{\mathrm{PW}}$ according to Hilhorst (2000):

$$
E C_{P W}=\frac{\varepsilon_{W} \cdot E C_{B}}{\varepsilon_{B}-\varepsilon_{E} C_{B=0}}
$$

where $\mathrm{EC}_{\mathrm{PW}}$ is the pore water electrical conductivity $\left(\mathrm{EC}_{\mathrm{PW}} \mathrm{GS} 3\right)$ and $\varepsilon_{\mathrm{W}}$ is the real portion of the dielectric permittivity of the soil pore water, which was calculated from soil temperature (Tsoil) using:

$$
\varepsilon_{W}=80.3-0.37(\text { Tsoil }-20)
$$

$\mathrm{EC}_{\mathrm{B}}$ is the bulk electrical conductivity measured directly by the sensor; $\varepsilon_{\mathrm{B}}$ is the real portion of the dielectric permittivity of the bulk soil; and $\varepsilon_{\mathrm{ECB}=0}$ is the real portion of the dielectric permittivity when $\mathrm{EC}_{\mathrm{B}}=0$ and 1.31 for the substrate used.

Irrigation was controlled manually with the help of the CR1000. The average $\theta$ considering all treatments was calculated at $09.00 \mathrm{~h}$. every day (except public holidays). If average $\theta$ was around $0.40 \mathrm{~m}^{3} \mathrm{~m}^{-3}$, irrigation was triggered. The irrigation events were consecutively applied at 20 min intervals in order to facilitate measuring the $\mathrm{EC}_{\mathrm{PW}}$ by the pour-through method and the collection of leachate in all the treatments. The volume of water applied per irrigation event $(470 \pm 12 \mathrm{~mL})$ and irrigation frequency (seventeen irrigation events in total) were the same in all treatments, which led to different leaching fractions being collected (from $18 \%$ in the control to $28 \%$ in the treatment involving $5 \mathrm{dS}$ $\left.\mathrm{m}^{-1} \mathrm{EC}_{\mathrm{IW}}\right)$.

\subsection{Measurements of EC using the pour-through method}

Leachate was collected in each irrigation event from pots using the PT method (Cavins et al., 2008). Thirty minutes after the crop had been irrigated $90 \mathrm{~mL}$ of distilled water was poured evenly over the surface of the substrate by hand and the extract was 
allowed to drain for 10 minutes, obtaining around $40 \mathrm{~mL}$ of leachate. In all measurements, the distilled water was applied on the same part of the substrate surface and between the two emitters. The leachate EC was then analyzed using a EC-meter (EC-Testr11, Eutech Instruments Pte Ltd, Singapore, Singapore) immediately after collection. Three pots per treatment were measured whenever a PT analysis was made. Different pots were used for each irrigation event.

\subsection{Growth, development and SPAD}

At the end of the experiment, plant height and width, shoot dry weight (DW), number of leaves, leaf area, number of inflorescences, and number of damaged leaves were determined in six plants per treatment. To calculate the shoot DW, the aerial part of the plant was placed in a natural convection bacteriological stove (model 2002471, JP Selecta SA, Barcelona, Spain) at $60^{\circ} \mathrm{C}$, and shoot DW was determined by weighing. The leaf area was determined with an LI-3100C (LI-COR Biosciences, Lincoln, NE) in the same plants whose shoot DW was measured. The presence of leaf burn, scorch or necrosis was considered as foliar damage. In order to study root growth five photographs were taken of the plant root (the four sides and the bottom of the root ball) with a digital camera (Panasonic LUMIX DMC-FX07 ${ }^{\circledR}$ ), and the root growth index was calculated as the percentage of root area in the root ball sides, using the image analysis software for plant disease quantification ASSESS 2.0 (University of Manitoba, Winnipeg, Canada).

The SPAD was measured in six plants of each treatment (four shots per plant), selecting representative south-facing, mid-height leaves. We used a SPAD-502 chlorophyll meter (Konica Minolta Sensing, Inc., Osaka, Japan), which estimates the relative chlorophyll content with the light transmitted through the leaf at $650 \mathrm{~nm}$ (photosynthetically active wave length) and at $940 \mathrm{~nm}$. SPAD measurements were made once per week throughout the experiment.

\subsection{Contents of chloride, sodium and potassium in plant}

The chloride, sodium and potassium contents were determined in leaves and roots. For this, dry tissue samples were ground, then, $0.2 \mathrm{~g}$ of dry tissue was added to $50 \mathrm{~mL}$ of distilled water. The solution was mixed for $30 \mathrm{~min}$ at $117 \mathrm{rpm}$ and $27{ }^{\circ} \mathrm{C}$ using an analogue magnetic stirrer, model ACS-100 C/C (ITC, SL, Barcelona, Spain), and filtered. 
Then, $10 \mathrm{~mL}$ of the filtered dissolution were analysed using the ion chromatography method in a Metrohm 850 Ion chromatography system (Metrohm AG, Herisau, Switzerland) equipped with an 838-861 column.

\subsection{Design and statistical analysis}

The experiment was a randomised complete block design with three blocks of seven plants per treatment set on crop tables. The regression analyses were performed using SigmaPlot 10.0 software (Systat Software Inc., San Jose, CA).

\section{Results and discussion}

\subsection{Plant growth and morphology}

Ornamental crop salt tolerance has usually been based on growth reduction of the whole plant or specific parts (Álvarez et al., 2012). In this experiment, plant height and shoot DW decreased with increasing $\mathrm{EC}_{\mathrm{IW}}$, while plant width was not affected (Table 1). Growers seek shorter, more compact plants because they are less expensive to ship and generally easier to maintain in greenhouses than taller plants (Burnett and van Iersel, 2008). In this respect, salinity irrigation could be used as a method for controlling height in vigorous varieties of osteospermum, avoiding or minimising the use of chemical retardants in potted production (Valdés et al., 2012). Cassaniti et al. (2009) indicated that the decrease in shoot DW and leaf area were the first visible effects of salinity both in sensitive and tolerant species. In the present experiment, neither leaf area nor the number of leaves was significantly affected by increasing $\mathrm{EC}_{\mathrm{IW}}$, probably because salinity produced thinner shoots and/or leaves, and/or shorter internodes (Wong, 1995; Wang, 1998). While some authors have noted that salinity inhibits root growth, involving a reduction in the length and mass of roots (Shannon and Grieve, 1999), in this work, increasing $\mathrm{EC}_{\mathrm{IW}}$ did not affect the root growth index (Table 1). This appoints to the good salt tolerance of osteospermum roots, perhaps because of its very vigorous root system, as we could check on the root ball.

However, for ornamental plants, aesthetic value is more important than the growth rate (Bañón et al., 2011). Thus, the effect of salinity on the number of flowers is important in ornamental plants. In our case, the number of inflorescences per plant was not affected 
by increasing $\mathrm{EC}_{\mathrm{IW}}$, which contrasts with the findings of other authors who found that the number of flowers was substantially reduced in other species such as narcissus (VeatchBlohm et al., 2014) and rose (Niu et al., 2013) as a result of salinity. Osteospermum showed a very high flowering capacity with around 60 inflorescences per plant (Picture 2). On the other hand, it is well known that saline irrigation can cause foliar damage, and the presence of leaves with necrotic damage (scorched margins and apices) increased with increasing $\mathrm{EC}_{\mathrm{IW}}$ (Table 1) was evident in our plants. Nevertheless, foliar damage was restricted to the basal leaves, which can be regarded as normal in osteospermum plants. The plants irrigated with the lowest $\mathrm{EC}_{\mathrm{IW}}$ had about $15 \%$ of their basal leaves damaged. Salinity not only causes leaf burn and necrosis, but also chlorosis, since chlorophyll degradation and synthesis is stimulated saline conditions (Santos, 2004). In this work the presence of foliar chlorosis was assessed by measuring SPAD, which is an indicator of leaf greenness (Monge and Bugbee, 1992), resulting in no signs of yellowing associated with increasing $\mathrm{EC}_{\mathrm{IW}}$ (Table 1).

Table 1. Linear regression models for growth parameters, plant ion content and irrigation water electrical conductivity $\left(\mathrm{EC}_{\mathrm{IW}}\right)$.

\begin{tabular}{|c|c|c|c|}
\hline Parameters & Equations & Signification & $\mathrm{R}^{2}$ \\
\hline Plant height $(\mathrm{cm})$ & $\mathrm{y}=33.35-1.79 \mathrm{EC}_{\mathrm{IW}}$ & $* * *$ & 0.32 \\
\hline Plant wide $(\mathrm{cm})$ & $\mathrm{y}=30.94+0.35 \mathrm{EC}_{\mathrm{IW}}$ & $\mathrm{ns}$ & 0.01 \\
\hline Shoot dry weight (g) & $\mathrm{y}=18.46-0.95 \mathrm{EC}_{\mathrm{IW}}$ & $* *$ & 0.22 \\
\hline Number of leaves & $\mathrm{y}=416.00-0.04 \mathrm{EC}_{\mathrm{IW}}$ & ns & $<0.01$ \\
\hline Leaf area $\left(\mathrm{dm}^{2}\right)$ & $\mathrm{y}=14.52-0.51 \mathrm{EC}_{\mathrm{IW}}$ & ns & 0.09 \\
\hline Root growth index & $\mathrm{y}=59.40-0.31 \mathrm{EC}_{\mathrm{IW}}$ & $\mathrm{ns}$ & 0.01 \\
\hline Number of inflorescences & $\mathrm{y}=54.53+2.29 \mathrm{EC}_{\mathrm{IW}}$ & $\mathrm{ns}$ & 0.11 \\
\hline Foliar SPAD & $\mathrm{y}=55.47+0.37 \mathrm{EC}_{\mathrm{IW}}$ & ns & 0.13 \\
\hline Foliar damage & $\mathrm{y}=10.37+2.12 \mathrm{EC}_{\mathrm{IW}}$ & $* *$ & 0.38 \\
\hline Leaf chloride $\left(\mathrm{mg} \mathrm{gDW}^{-1}\right)$ & $\mathrm{y}=72.78+3.05 \mathrm{EC}_{\mathrm{IW}}$ & $* * *$ & 0.55 \\
\hline Root chloride (mg gDW ${ }^{-1}$ ) & $\mathrm{y}=17.13+12.22 \mathrm{EC}_{\mathrm{IW}}$ & $* * *$ & 0.83 \\
\hline Leaf sodium (mg gDW ${ }^{-1}$ ) & $\mathrm{y}=14.71+5.29 \mathrm{EC}_{\mathrm{IW}}$ & $* * *$ & 0.71 \\
\hline Root sodium (mg gDW $\left.{ }^{-1}\right)$ & $\mathrm{y}=8.34+6.86 \mathrm{EC}_{\mathrm{IW}}$ & $* * *$ & 0.76 \\
\hline Leaf potassium $\left(\mathrm{mg} \mathrm{gDW}^{-1}\right)$ & $\mathrm{y}=31.77-2.78 \mathrm{EC}_{\mathrm{IW}}$ & $* * *$ & 0.77 \\
\hline Root potassium (mg gDW $\left.{ }^{-1}\right)$ & $\mathrm{y}=17.80+1.71 \mathrm{EC}_{\mathrm{IW}}$ & $*$ & 0.27 \\
\hline
\end{tabular}




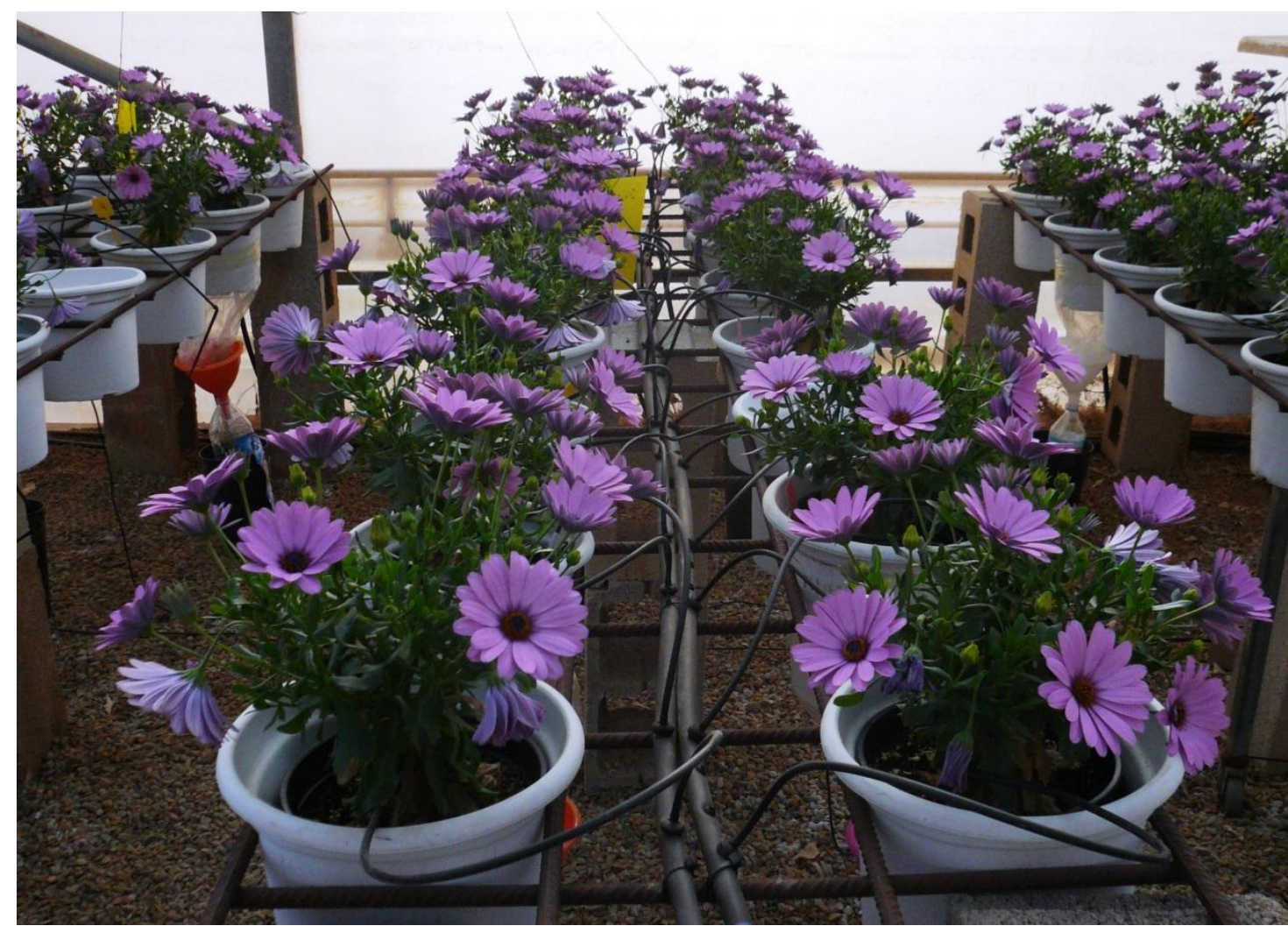

Picture 2. Plants in the flowering phase at the end of experiment.

\subsection{Contents of chloride, sodium and potassium in plant}

Leaf and root chloride content increased as $\mathrm{EC}_{\mathrm{IW}}$ increased (Table 1). However, a higher slope for the root chloride- $\mathrm{EC}_{\mathrm{IW}}$ fit than for the leaf chloride- $\mathrm{EC}_{\mathrm{IW}}$ fit indicates that the increase in chloride in the roots was greater than that in leaves. Despite the high leaf chloride content, ranging from 75 (control) to $90\left(5 \mathrm{dS} \mathrm{m}^{-1} \mathrm{EC}_{\mathrm{IW}}\right) \mathrm{mg} \mathrm{g}^{-1} \mathrm{DW}$, the plants showed no symptoms of foliar necrosis. It is important to remember that the analysed leaves were picked from the middle part of the shoots, while necrosis was only observed in the basal leaves. Such levels of foliar chloride could be related to the efficient salt compartmentalization of osteospermum (Sánchez-Blanco et al., 2004).

Osteospermum accumulated less sodium than chloride in both leaves and roots. Foliar sodium concentrations ranged were from 23 (control) to $41 \mathrm{mg} \mathrm{g}^{-1} \mathrm{DW}\left(5 \mathrm{dS} \mathrm{m}^{-1}\right.$ $\mathrm{EC}_{\mathrm{IW}}$ ). This pattern of toxic ion accumulation has been reported in other plant species (Grewal, 2010). Foliar and root sodium concentration also responded linearly to increasing $\mathrm{EC}_{\mathrm{IW}}$ : the higher $\mathrm{EC}_{\mathrm{IW}}$, the higher sodium content in both organs. Unlike the pattern of chloride accumulation, sodium accumulation in roots was similar to that in leaves (similar 
regression equations, see Table 1), suggesting that osteospermum does not possess a mechanism for limiting the transport of sodium to the aerial parts (Yadav et al., 2011). In the absence of this salt stress resistance mechanism, the hypothesis of efficient sodium compartmentalization in the vacuoles becomes more defensible.

It has been generally observed that plants exposed to saline environments take up high amounts of sodium, while potassium uptake is significantly less. In this study, the concentration of potassium in the leaves decreased linearly with increasing $\mathrm{EC}_{\mathrm{IW}}$, whereas the contrary occurred in the roots (Table 1). A reduction in the potassium content as salinity increased was also detected in leaves of Arbutus unedo (Navarro et al., 2008). In some studies, the cause of such a decrease in leaves was reported to be due to the existence of antagonistic relationship between sodium and potassium at the root surface (Meloni et al., 2008). However, other studies attributed this result to the suppression of potassium transport to the shoot rather than to antagonism (Song and Fujiyama, 1998). The last assumption is consistent with our observations in the present experiment because slope of the foliar potassium-EC $\mathrm{CW}_{\mathrm{IW}}$ linear equation was negative but was positive in the root potassium- $\mathrm{EC}_{\mathrm{IW}}$ equation (Table 1).

\subsection{Effect of increasing $E C_{I W}$ on the mean electrical conductivities values}

As expected, the mean $\mathrm{EC}_{\mathrm{L}}, \mathrm{EC}_{\mathrm{PW}} \mathrm{PT}$ and $\mathrm{EC}_{\mathrm{PW}} \mathrm{GS} 3$ throughout the experimental period increased as $\mathrm{EC}_{\mathrm{IW}}$ increased (Fig. 1). The three models $\left(\mathrm{EC}_{\mathrm{L}}-\mathrm{EC}_{\mathrm{IW}}, \mathrm{EC}_{\mathrm{PW}} \mathrm{PT}-\mathrm{EC} \mathrm{IW}_{\mathrm{IW}}\right.$ and $\left.\mathrm{EC}_{\mathrm{PW}} \mathrm{GS} 3-\mathrm{EC}_{\mathrm{IW}}\right)$ of linear regression studied were significant and all them showed strong relationships $\left(\mathrm{R}^{2}>0.87\right)$. The $\mathrm{EC}_{\mathrm{L}}-\mathrm{EC}_{\mathrm{IW}}$ equation had a steeper slope than the $\mathrm{EC}_{\mathrm{PW}} \mathrm{PT}-\mathrm{EC}_{\mathrm{IW}}$ equation, meaning that $\mathrm{EC}_{\mathrm{L}}$ values were higher than those of $\mathrm{EC}_{\mathrm{PW}} \mathrm{PT}$ for the same $\mathrm{EC}_{\mathrm{IW}}$. One explanation for this could be that the first part of the leachate contains more salts than the last part, which is similar to the leachate collected using the PT method. The differences between $\mathrm{EC}_{\mathrm{PW}} \mathrm{PT}$ and $\mathrm{EC}_{\mathrm{L}}$ values grew with increasing $\mathrm{EC}_{\mathrm{IW}}$ because the $\mathrm{EC}_{\mathrm{L}}$ data scatter increased as the $\mathrm{EC}_{\mathrm{IW}}$ became higher. This variability in $\mathrm{EC}_{\mathrm{L}}$ was probably due to the strong influence that the leaching fraction has on $\mathrm{EC}_{\mathrm{L}}(\mathrm{Ku}$ and Hershey, 1992), poor uniformity in substrate moisture under drip irrigation (Valdés et al., 2014b) and the irregular physiological state of the salinized plants (Gómez-Bellot et al., 2013). By contrast, the slope of the $\mathrm{EC}_{\mathrm{PW}} \mathrm{GS} 3-\mathrm{EC}_{\mathrm{IW}}$ equation was lower than that of the $\mathrm{EC}_{\mathrm{PW}} \mathrm{PT}-\mathrm{EC}_{\mathrm{IW}}$ equation, and, as was the case for $\mathrm{EC}_{\mathrm{L}}$, increasing $\mathrm{EC}_{\mathrm{IW}}$ resulted in greater 
variability of the $\mathrm{EC}_{\mathrm{PW}} \mathrm{GS} 3$ values (Fig. 1). The method used to estimate $\mathrm{EC}_{\mathrm{PW}} \mathrm{GS} 3$ (Hilhorst, 2000) might have been the cause of this variability, since soil moisture and salinity may affect the measurement (Valdés et al., 2014a). In the same way, Van Der Laan et al. (2011) found difficulties when estimating soil solution EC from measured $\mathrm{EC}_{\mathrm{B}}$ using ECH20-TE sensors at low soil water content values. Valdés et al. (2012) identified a salinity effect on the HPII-sensor $\varepsilon_{B}$ readings, with increasing data scatter as salinity increased, while Kargas and Kerkides (2010) indicated the value of $\varepsilon_{\mathrm{ECB}=0}$ in the Hilhorst model increases when the salinity level increases.

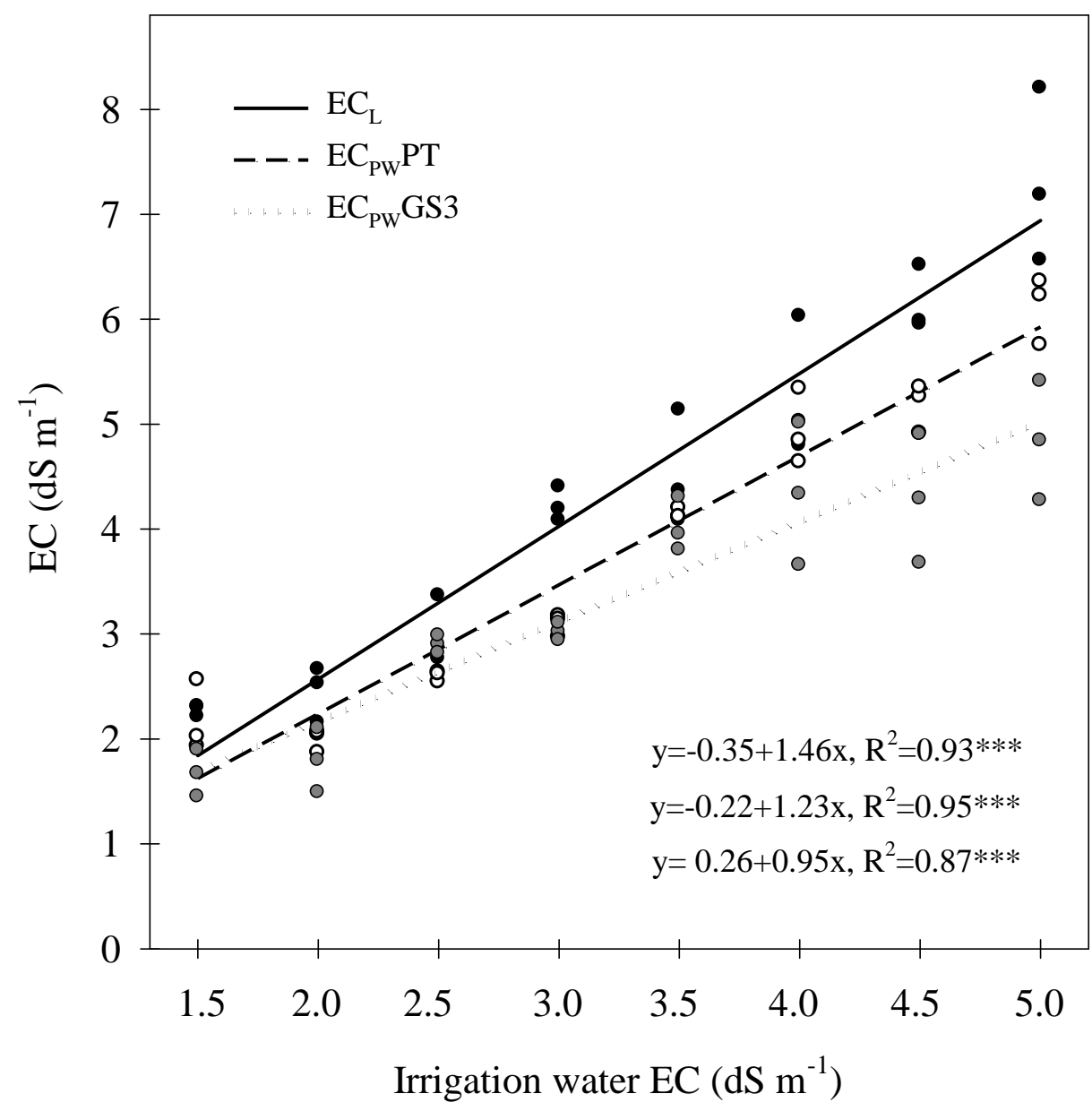

Figure 1. Changes in leachate $\mathrm{EC}\left(\mathrm{EC}_{\mathrm{L}}\right)$, pour-through pore water $\mathrm{EC}\left(\mathrm{EC}_{\mathrm{PW}} \mathrm{PT}\right), \mathrm{GS} 3$ pore water $\mathrm{EC}\left(\mathrm{EC}_{\mathrm{PW}} \mathrm{GS} 3\right)$ with irrigation water EC. The data shown are mean values throughout the growth cycle. *** indicates significant at $P<0.001$. 


\subsection{Relationships among electrical conductivities}

A regression study showed a significant linear relationship for $\mathrm{EC}_{\mathrm{PW}} \mathrm{PT}-\mathrm{EC}_{\mathrm{B}}$, $\mathrm{EC}_{\mathrm{PW}} \mathrm{PT}-\mathrm{EC}_{\mathrm{PW}} \mathrm{GS} 3$ and $\mathrm{EC}_{\mathrm{PW}} \mathrm{PT}-\mathrm{EC}_{\mathrm{L}}$ (Fig. 2). All these fits were strong $\left(\mathrm{R}^{2} \geq 0.82\right)$, suggesting that $\mathrm{EC}_{\mathrm{B}}, \mathrm{EC}_{\mathrm{PW}} \mathrm{GS} 3$ and $\mathrm{EC}_{\mathrm{L}}$ can be used as indicators to estimate real substrate solution salinity $\left(\mathrm{EC}_{\mathrm{PW}} \mathrm{PT}\right)$. The slopes of these regression equations indicate that $\mathrm{EC}_{\mathrm{L}}$ values overestimate the level of pore water salinity, while $\mathrm{EC}_{\mathrm{PW}} \mathrm{GS} 3$ values underestimate it: the higher the $\mathrm{EC}_{\mathrm{IW}}$, the greater the error. As regards $\mathrm{EC}_{\mathrm{B}}$, the slope of the $\mathrm{EC}_{\mathrm{PW}} \mathrm{PT}-\mathrm{EC}_{\mathrm{B}}$ equation was the steepest, $\mathrm{EC}_{\mathrm{B}}$ values being 3-4 times lower than those in $\mathrm{EC}_{\mathrm{PW}} \mathrm{PT}$ (Fig. 2). However, the $\mathrm{EC}_{\mathrm{PW}} \mathrm{GS} 3$ values were slightly lower than $\mathrm{EC}_{\mathrm{PW}} \mathrm{PT}$ values. Despite this, the $\mathrm{EC}_{\mathrm{B}}$ was better related with $\mathrm{EC}_{\mathrm{PW}} \mathrm{PT}$ than with $\mathrm{EC}_{\mathrm{PW}} \mathrm{GS} 3$ (higher $\mathrm{R}^{2}$ ) for the following reasons. First, because the $\mathrm{EC}_{\mathrm{B}}$ was measured immediately following irrigation, and it is strongly influenced by soil moisture content (Rhoades et al., 1989; Mualem and Friedman, 1991; Robinson et al., 1999; Valdés et al., 2014c) - we found a significant linear fit between $\mathrm{EC}_{\mathrm{PW}} \mathrm{GS} 3$ and $\mathrm{EC}_{\mathrm{B}}$ (Fig. 3), which was stronger (higher $\mathrm{R}^{2}$ ) after irrigating (high humidity) than before irrigating. Second, because $\mathrm{EC}_{\mathrm{PW}} \mathrm{GS} 3$ was calculated using the Hilhorst's model and, as mentioned earlier, several factors may affect this estimation, including the soil moisture content (Van Der Laan et al., 2011), salinity (Kargas and Kerkides, 2010; Valdés et al., 2012) and soil type (Nadler, 2004; Kargas and Kerkides, 2012). The two last authors found the Hilhorst's model overestimates $\mathrm{EC}_{\mathrm{PW}}$ for salinity values up to $1.2 \mathrm{dS} \mathrm{m}^{-1}$, while for larger values it significantly underestimates the same, as occurred in our experiment. Consequently, the $\mathrm{EC}_{\mathrm{B}}$ can also be regarded as an appropriate indicator for ascertaining substrate salinity when it is measured in the presence of a high substrate moisture content . Clear evidence of this was found when $\mathrm{EC}_{\mathrm{B}}$ was measured after irrigating potted hydrangea (Valdés et al., 2013) and poinsettia (Valdés et al., 2014c). 


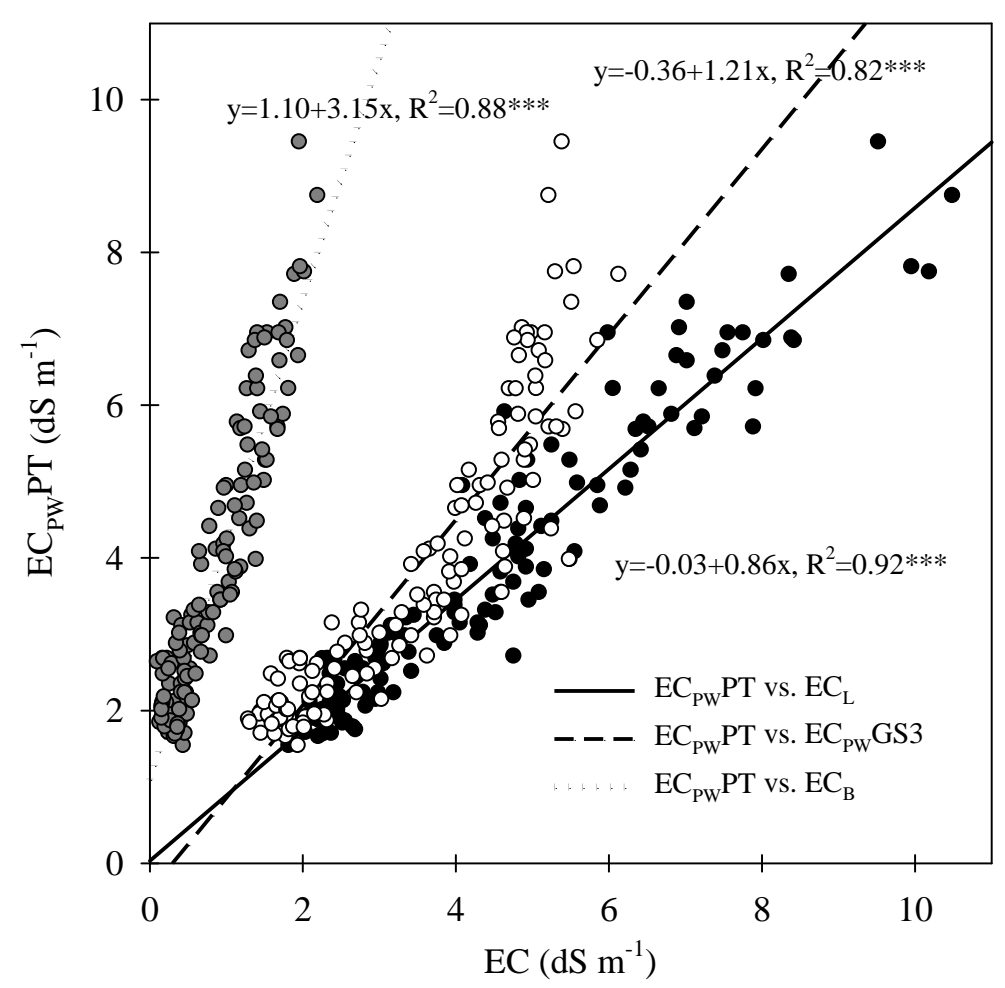

Figure 2. Linear fit between pour-through pore water $\mathrm{EC}\left(\mathrm{EC}_{\mathrm{PW}} \mathrm{PT}\right)$, leachate $\mathrm{EC}\left(\mathrm{EC}_{\mathrm{L}}\right), \mathrm{GS} 3$ pore water EC (EC $\left.\mathrm{EW}_{\mathrm{PW}} \mathrm{GS}\right)$ and bulk EC $\left(\mathrm{EC}_{\mathrm{B}}\right)$. *** indicates significant at $P<0.001$.

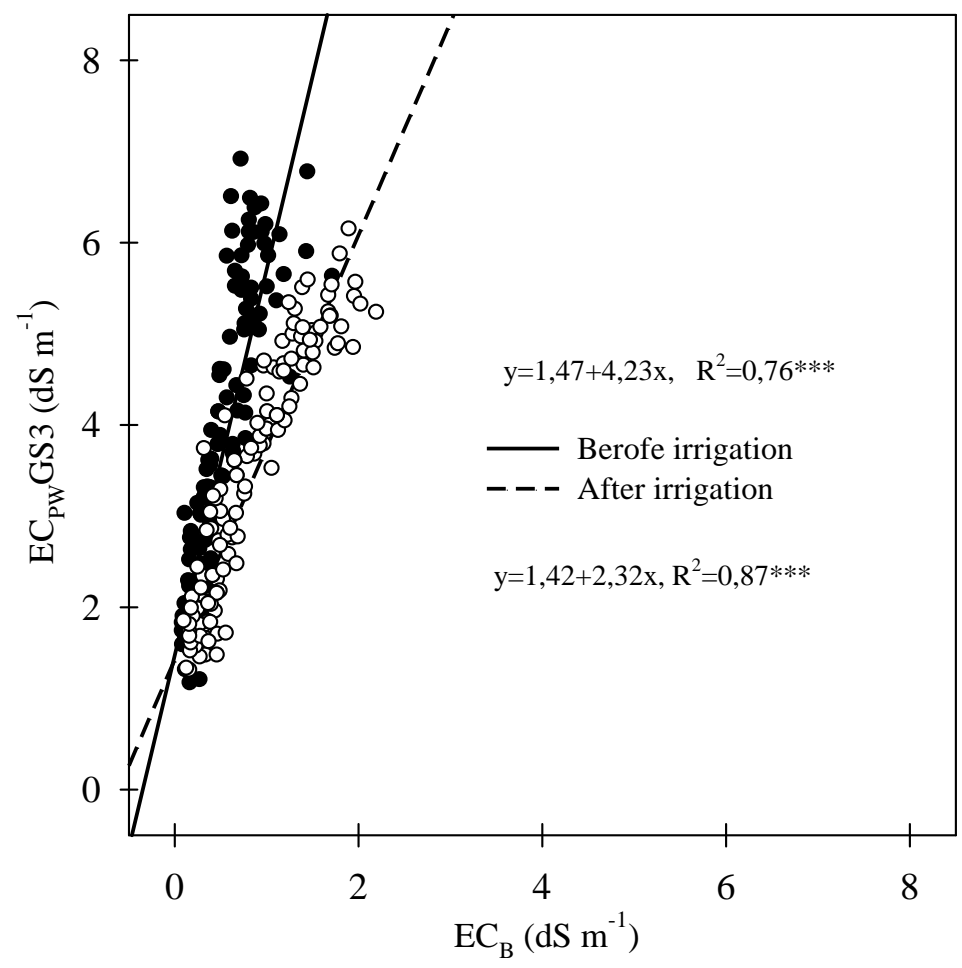

Figure 3. Linear fit between bulk $\mathrm{EC}\left(\mathrm{EC}_{\mathrm{B}}\right)$ and pore water $\mathrm{EC}\left(\mathrm{EC}_{\mathrm{PW}} \mathrm{GS} 3\right)$ before and after irrigation. $* * *$ indicates significant at $P<0.001$. 


\subsection{Evolution of the substrate $\theta, E C_{P W}$ and $E C_{B}$ obtained using the GS3 sensor}

Figure 4 shows the evolution of substrate $\theta, \mathrm{EC}_{\mathrm{B}}$ and $\mathrm{EC}_{\mathrm{PW}} \mathrm{GS} 3$ during the course of the 40-day experiment. The pots irrigated with low EC water reached lesser substrate $\theta$ values than those irrigated with higher EC water. This would be due to the fact that all treatments were irrigated with the same irrigation frequency and water volume, since the less salinized plants consumed more water (higher growth). This led to low leaching fraction in the pots with less salt because they retained more water after irrigating than those with more salt. As can be seen in Figure 4, substrate $\theta$ fell following irrigation due to drainage (at the beginning) followed by evapotranspiration. At low $\mathrm{EC}_{\mathrm{IW}}$ this drop was faster than at higher $\mathrm{EC}_{\mathrm{IW}}$ values, because salinized plants transpire less and the substrate evaporates less water since the salt helps retain it (Valdés et al., 2014b).

$\mathrm{EC}_{\mathrm{B}}$ increased immediately afterwards irrigating, and then gradually fell as the substrate dried out: the higher the $\mathrm{EC}_{\mathrm{IW}}$, the greater the increase in $\mathrm{EC}_{\mathrm{B}}$ (Fig. 4 and Table 2). In general, the evolution of $\mathrm{EC}_{\mathrm{B}}$ between two irrigation events was more or less stable for all the $\mathrm{EC}_{\mathrm{IW}}$ values studied. This was especially true at the lowest salinity levels (Fig. $5 \mathrm{~A}$ ), while at the highest $\mathrm{EC}_{\mathrm{IW}}$ levels small dips in the $\mathrm{EC}_{\mathrm{B}}$ curve were observed (Fig. $5 \mathrm{~B}$ ). In addition, when the relationship between $\mathrm{EC}_{\mathrm{B}}$ data and the time from the irrigation event was studied significant linear regression models were obtained, with negative slope for all the $\mathrm{EC}_{\mathrm{IW}}$ studied (Table 2). Overall, the higher the $\mathrm{EC}_{\mathrm{IW}}$, the steeper the slope, because $\mathrm{EC}_{\mathrm{B}}$ is more influenced by changes in moisture when salinity is high (Malicki and Walczak, 1999; Amente et al., 2000).

Immediately after irrigating, the $\mathrm{EC}_{\mathrm{PW}} \mathrm{GS} 3$ values clearly increased in the pots with $\mathrm{EC}_{\mathrm{IW}} \leq 3 \mathrm{dS} \mathrm{m}^{-1}$ then gradually decreasing as the substrate dried out (Fig. 4). However, a decrease in the real $\mathrm{EC}_{\mathrm{PW}}$ after irrigating is to be expected because the salt is flushed out. Then, the real $\mathrm{EC}_{\mathrm{PW}}$ increases because the salt stays in the substrate while the water is being removed. Nevertheless, with $\mathrm{EC}_{\mathrm{IW}} \geq 3.5 \mathrm{dS} \mathrm{m}^{-1}$ the $\mathrm{EC}_{\mathrm{PW}} \mathrm{GS} 3$ moves erratically, with strong fluctuations in the $\mathrm{EC}_{\mathrm{PW}} \mathrm{GS} 3$ curves because salinity influences the $\varepsilon_{\mathrm{B}}$ (Campbell, 2002; Seyfried and Murdock, 2004; Valdés et al., 2012). A more detailed observation of such fluctuations shows how the highest temperature values (around midday) coincide with the lowest $\mathrm{EC}_{\mathrm{PW}} \mathrm{GS} 3$ values (Fig. 5). This confirms the influence of temperature on the $\mathrm{EC}_{\mathrm{PW}} \mathrm{GS} 3$, which increased as salinity increased. Rosenbaum et al. (2011) found that $\varepsilon_{\mathrm{B}}$ was underestimated at low temperature and overestimated at high temperatures when using capacitive soil sensors, and Seyfried and Grant (2007) also 
detected a temperature effect on Hydra Probe II sensor outputs. Moreover, but to a lesser extent, the $\mathrm{EC}_{\mathrm{B}}$ could also influence the erratic behaviour of the $\mathrm{EC}_{\mathrm{PW}} \mathrm{GS} 3$ curves because small dips were observed under high $\mathrm{EC}_{\mathrm{IW}}$ when temperature increased (Fig. 5B). These findings show that the Hilhorst's model does not work well when the substrate water content is low and salinity is high. However, the mean $\mathrm{EC}_{\mathrm{PW}} \mathrm{GS} 3$ values calculated between two irrigation events increased as the growth cycle advanced, the increase being greater with $\mathrm{EC}_{\mathrm{IW}} \geq 3.5 \mathrm{dS} \mathrm{m}^{-1}$ than with $\mathrm{EC}_{\mathrm{IW}}<3 \mathrm{dS} \mathrm{m}^{-1}$ (Fig. 6). So, using the mean $\mathrm{EC}_{\mathrm{PW}}$ could be more useful for controlling salinity than a single value. Evidence of this was also found by Valdes et al. (2014a) in a cultivation of potted geranium irrigated with saline water.

Table 2. Evolution of bulk EC values (each half hour) following irrigation. Linear fits for eight levels of $\mathrm{EC}_{\mathrm{IW}}$ are shown. Bulk EC data were collected from the 22 of December of 2013 to 3 of January of 2014 (between two irrigation events). $y=$ bulk EC and $x=$ time after the irrigation event.

\begin{tabular}{cccc}
\hline $\left.\mathrm{EC}_{\mathrm{IW}}(\mathrm{dS} \mathrm{m})^{-1}\right)$ & Equations & Signification & \multicolumn{1}{c}{$\mathrm{R}^{2}$} \\
\hline 1.5 & $\mathrm{y}=0.3794-0.0007 \mathrm{x}$ & $* * *$ & 0.98 \\
2.0 & $\mathrm{y}=0.4404-0.0006 \mathrm{x}$ & $* * *$ & 0.96 \\
2.5 & $\mathrm{y}=0.7907-0.0011 \mathrm{x}$ & $* * *$ & 0.98 \\
3.0 & $\mathrm{y}=0.9664-0.0012 \mathrm{x}$ & $* * *$ & 0.91 \\
3.5 & $\mathrm{y}=1.4570-0.0017 \mathrm{x}$ & $* * *$ & 0.97 \\
4.0 & $\mathrm{y}=1.6848-0.0021 \mathrm{x}$ & $* * *$ & 0.98 \\
4.5 & $\mathrm{y}=1.4628-0.0015 \mathrm{x}$ & $* * *$ & 0.96 \\
5.0 & $\mathrm{y}=1.9293-0.0023 \mathrm{x}$ & $* * *$ & 0.97 \\
\hline
\end{tabular}

*** indicates significant at $P<0.001$ 


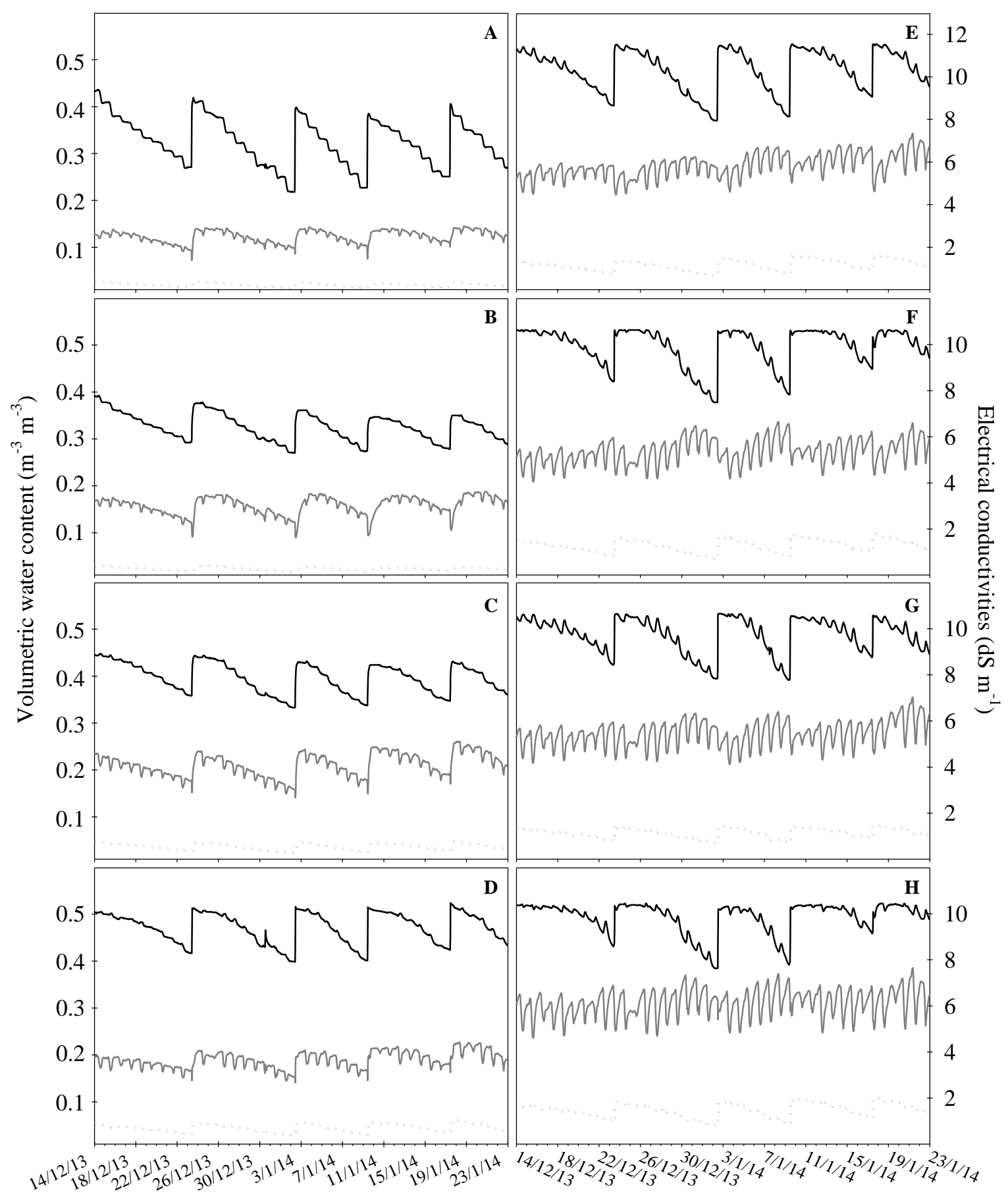

Date

Figure 4. Evolution of substrate volumetric water content (solid black line), pore water EC (solid grey line) and bulk EC (dotted grey line) from the 14 December 2013 to 23 January 2014. EC $_{\text {IW }}$ $1.5 \mathrm{dS} \mathrm{m}^{-1}(\mathrm{~A}) ; \mathrm{EC}_{\mathrm{IW}} 2 \mathrm{dS} \mathrm{m}^{-1}(\mathrm{~B}) ; \mathrm{EC}_{\mathrm{IW}} 2.5 \mathrm{dS} \mathrm{m}^{-1}$ (C); $\mathrm{EC}_{\mathrm{IW}} 3 \mathrm{dS} \mathrm{m}^{-1}(\mathrm{D}) ; \mathrm{EC}_{\mathrm{IW}} 3.5 \mathrm{dS} \mathrm{m}^{-1}(\mathrm{E}) ;$ $\mathrm{EC}_{\mathrm{IW}} 4 \mathrm{dS} \mathrm{m}^{-1}(\mathrm{~F}) ; \mathrm{EC}_{\mathrm{IW}} 4.5 \mathrm{dS} \mathrm{m}^{-1}(\mathrm{G})$ and $\mathrm{EC}_{\mathrm{IW}} 5 \mathrm{dS} \mathrm{m}^{-1}(\mathrm{H})$. 


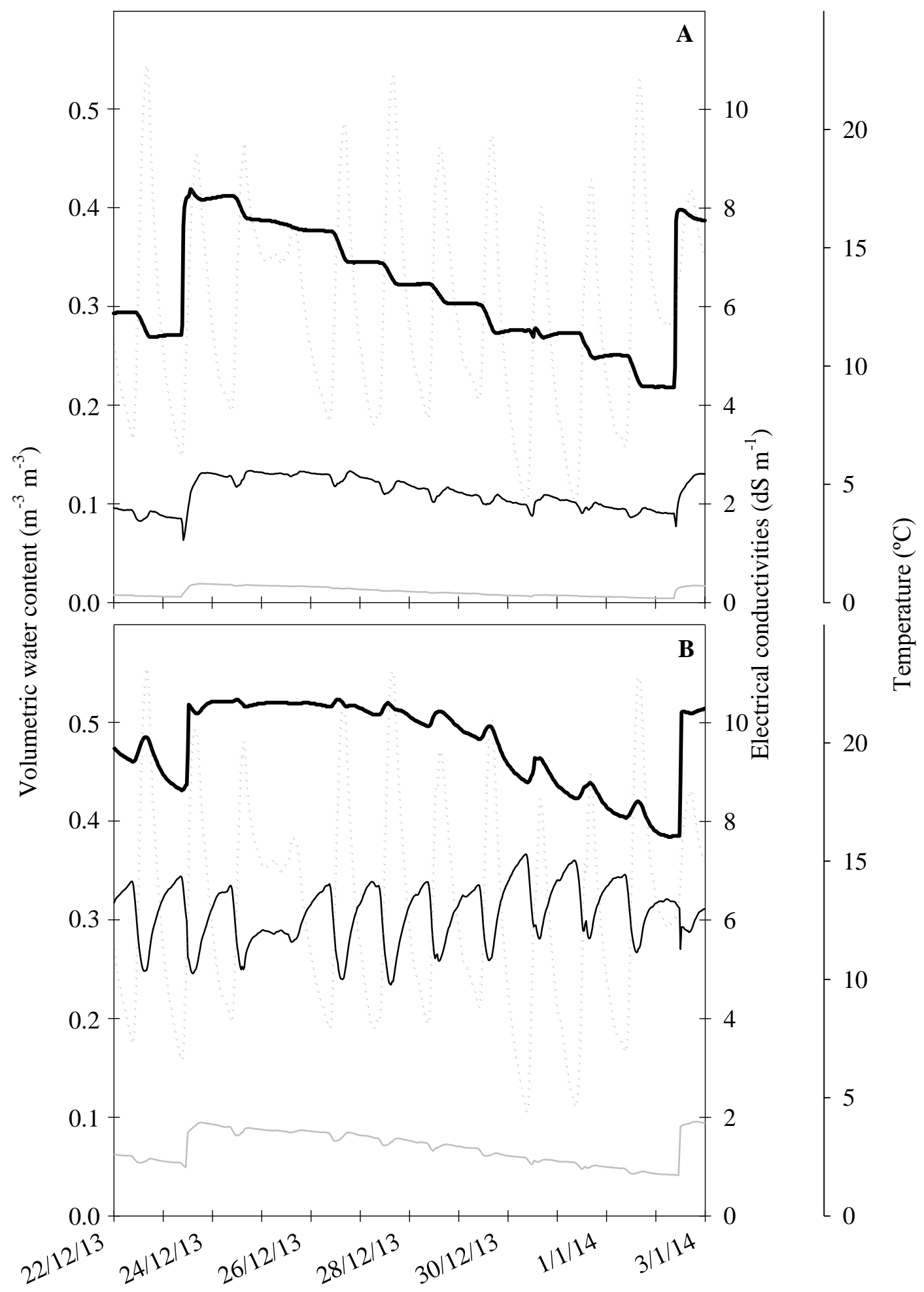

Date

Figure 5. Evolution of substrate volumetric water content (thick black solid line), pore water EC (thin black solid line), bulk EC (grey solid line) and substrate temperature (grey dotted line) between two irrigation events (from the 22 December 2013 to 3 January 2014). $\mathrm{EC}_{\mathrm{IW}} 1.5 \mathrm{dS} \mathrm{m}^{-1}$ (A) and $\mathrm{EC}_{\mathrm{IW}} 5 \mathrm{dS} \mathrm{m}^{-1}(\mathrm{~B})$. 


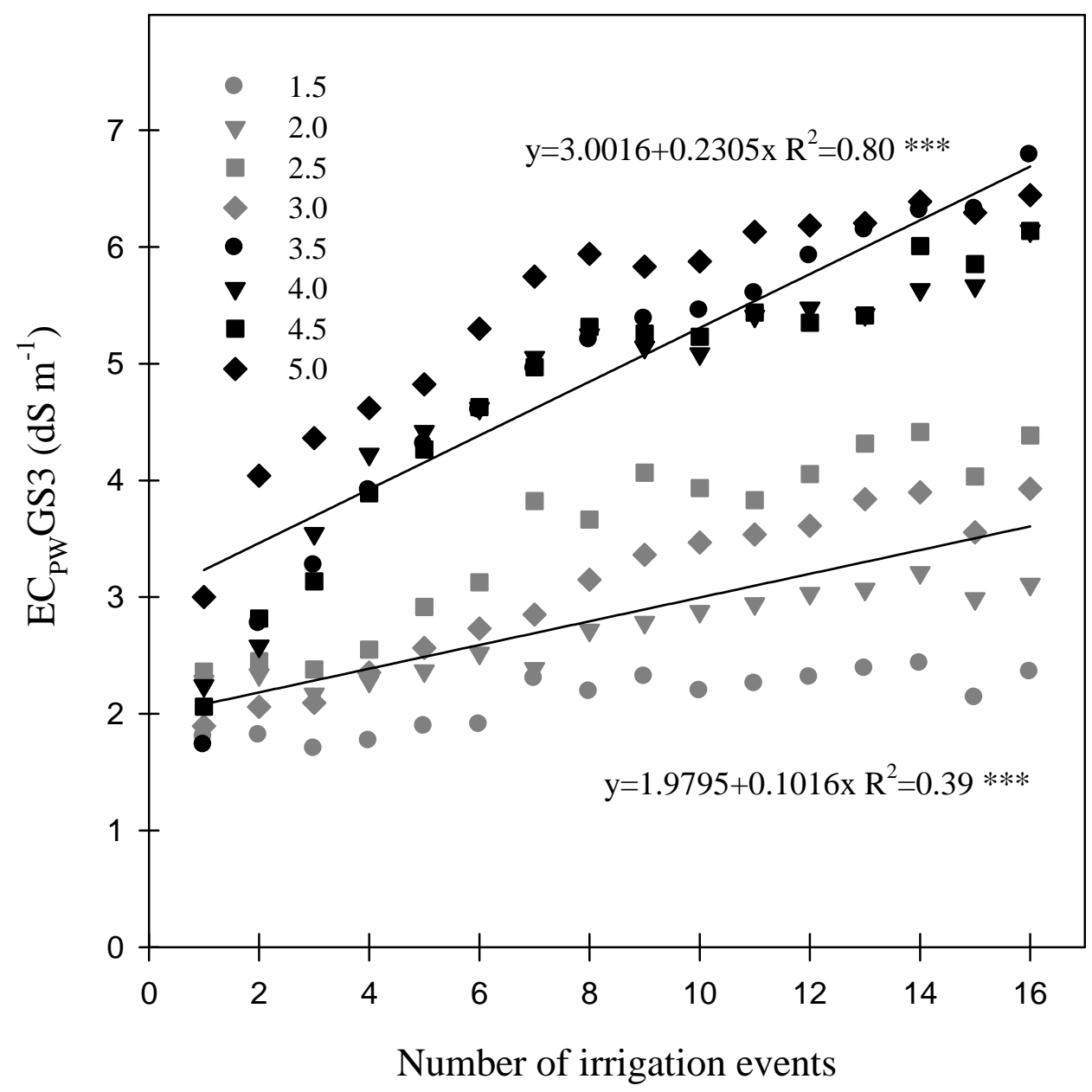

Figure 6. Linear relationships between the number of irrigation events applied and the mean $\mathrm{EC}_{\mathrm{PW}} \mathrm{GS} 3$ obtained from recorded data between two irrigation events. $* * *$ indicates significant at $P<0.001$.

\section{Conclusion}

Although saline irrigation water produced shorter osteospermum plants and promoted the presence of damaged leaves in the basal part of the plant, the ornamental appearance was not affected, indicating that osteospermum is a moderately salt sensitive plant. Such tolerance is due to its high capacity to accumulate chloride and sodium in the leaves without showing damage. Sodium accumulation caused a decrease in foliar potassium content due to the suppression of potassium transport to the shoot. $\mathrm{EC}_{\mathrm{B}}$ was closely related with $\mathrm{EC}_{\mathrm{PW}} \mathrm{PT}$ and decreased uniformly as the substrate dried out. Both the post-irrigation $\mathrm{EC}_{\mathrm{B}}$ values and the way in which the $\mathrm{EC}_{\mathrm{B}}$ data decrease (slope) might be helpful for controlling substrate salinity. Both $\mathrm{EC}_{\mathrm{L}}$ and $\mathrm{EC}_{\mathrm{PW}} \mathrm{GS} 3$ were well related to real 
pore water salinity $\left(\mathrm{EC}_{\mathrm{PW}} \mathrm{PT}\right)$, but the former overestimated it, whereas the latter underestimated it; furthermore, as salinity increased both errors became larger. Substrate moisture influence the estimation of $\mathrm{EC}_{\mathrm{PW}} \mathrm{GS} 3$ : the lower the substrate moisture, the greater the underestimation. Increasing irrigation salinity increased fluctuations in the $\mathrm{EC}_{\mathrm{PW}} \mathrm{GS} 3$ data because the temperature effect became higher. Using the mean values of $\mathrm{EC}_{\mathrm{PW}} \mathrm{GS} 3$ is more recommendable than using a single value for controlling substrate salinity.

\section{Acknowledgements}

We are grateful for the financial aid received from the Ministerio de Economía y Competitividad and FEDER through the projects (AGL2011-30022-C02-1 and AGL201130022-C02-2) and SENECA project (08669/PI/08).

\section{References}

Álvarez, S., Gómez-Bellot, M.J., Castillo, M., Bañón, S., Sánchez-Blanco, M.J., 2012. Osmotic and saline effect on growth, water relations, and ion uptake and translocation in Phlomis purpurea plants. Environ Exp Bot. 78, 138-145.

Amente, G., Baker, J.M., Reece, C.F., 2000. Estimation of Soil Solution Electrical Conductivity from Bulk Soil Electrical Conductivity in Sandy Soils. Soil Sci. Soc. Am. J. 64, 1931-1939.

Bañón, S., Miralles, J., Franco, J.A., Ochoa, R., Sánchez-Blanco, M.J., 2011. Effects of diluted and pure treated wastewater on the growth, physiological status and visual quality of potted lantana and polygala plants. Sci. Hortic. 129, 869-876.

Bayuelo-Jiménez, J.S., Debouck, G.D., Lynch, J.P., 2003. Growth, gas exchange, water relations, and ion composition of Phaseolus species grown under saline conditions. Field. Crop. Res. 80, 207-222.

Burnett, S.E., van Iersel, M., 2008. Morphology and irrigation efficiency of Gaura lindheimeri grown with capacitance sensor-controlled irrigation. HortScience 43, 1555-1560. 
Campbell, J.E., 2002. Salinity effects in capacitive soil moisture measurement. In: I.C. Paltineau (Ed.), Transactions first international symposium on soil water measurement using capacitance and impedance. Paltin International Inc., Maryland, USA, pp. 1-12.

Cassaniti, C., C. Leonardi, Flowers, T.J., 2009. The effects of sodium chloride on ornamental shrubs. Scientia Hort. 122, 586-593.

Cavins, T., Whipker, B., Fonteno, W., 2008. PourThrough: A method for monitoring nutrition in the greenhouse. Acta Hort. 779, 289-297.

Dudley L.M., 1992. Salinity in the soil environment. In: Handbook of Plant and Crop Stress, M. Pessarakli (Ed.), Marcel Dekker, New York, 13-30.

Franco, J.A., Fernández, J.A., Bañón, S., González, A., 1997. Relationship between the effects of salinity on seedling leaf area and fruit yield of six muskmelons cultivars. HortScience 32, 642-644.

Gibson, J.L., Whipker, B.E., 2003. Efficacy of Plant Growth Regulators on the Growth of Vigorous Osteospermum Cultivars. HortTechnology 13, 132-135.

Gómez-Bellot, M. J., Álvarez, S., Bañón, S., Ortuño, M. F., Sánchez-Blanco, M. J., 2013. Physiological mechanisms involved in the recovery of euonymus and laurustinus subjected to saline waters. Agr. Water. Manage. 128, 131-139.

Grewal, H.S., 2010. Water uptake, water use efficiency, plant growth and ionic balance of wheat, barley, canola and chickpea plants on a sodic vertosol with variable subsoil $\mathrm{NaCl}$ salinity. Agric. Water Manage. 97, 148-156.

Grieve, C.M., Shannon M.C., 1999. Ion Accumulation and Distribution in Shoot Components of Salt-stressed Eucalyptus Clones. J. Amer. Soc. Hort. Sci. 124, 559563.

Hasegawa, P.M., Bressan, R.A., Zhu, J.-K., Bohnert, H.J.,2000. Plant cellular and molecular responses to high salinity. Annu. Rev. Plant Physiol. Plant Mol. Biol. 51, 463-499.

Hilhorst, M.A., 2000. A pore water conductivity sensor. Soil Sci. Soc. Am. J. 64, 19221925.

Incrocci, L., Marzialetti, P., Incrocci, G., Balendonck, J., Spagnol, S., Pardossi, A., 2010. Application of WET Sensor for Management of Reclaimed Wastewater Irrigation in Container-Grown Ornamentals (Prunus laurocerasus L.). Transactions of the Third International Symposium on Soil Water Measurement Using Capacitance, Impedance and TDT, Murcia, Spain, 7-9 April 2010. 
Kargas, G., Kerkides, P., 2010. Evaluation of a Dielectric Sensor for Measurement of Soil-Water Electrical Conductivity. J. Irrig. Drain. E., 136, 553-558

Kargas, G., Kerkides, P., 2012. Comparison of two models in predicting pore water electrical conductivity in different porous media. Geoderma 189, 563-573.

Kelleners, T. J., Soppe, R. W. O., Ayars, J. E., Skaggs, T. H., 2004. Calibration of capacitance probe sensors in a saline silty clay soil. Soil Sci. Soc. Am. J. 68, 770-778.

Ku, C.S., Hershey, D.R., 1991. Leachate electrical conductivity and growth of potted poinsettia with leaching fractions of 0 to 0.4. J. Am. Soc. Hortic. Sci. 116, 802-806.

Ku, C.S., Hershey, D.R., 1992. Leachate electrical conductivity and growth of potted geranium with leaching fractions of 0 to 0.4. J. Amer. Soc. Hort. Sci. 117, 893-897.

Malicki, M.A., Walczak, R.T., 1999. Evaluating soil salinity status from bulk electrical conductivity and permittivity. Eur. J. Soil Sci. 50, 505-514

Meloni, D.A., Gulotta, M.R., Martinez, C.A., 2008. Salinity tolerance in Schinopsis quebracho colorado: Seed germination, growth, ion relations and metabolic responses. J. Arid Environ. 72, 1785-1792.

Monge, O.A., Bugbee, B., 1992. Inherent limitations of nondestructive chlorophyllmeters: a comparison of two types of meters. HortScience 27, 69-71.

Mualem, Y., Friedman S.P., 1991. Theoretical Prediction of Electrical Conductivity in saturated and unsaturated soil. Water Resour. Res. 27, 2771-2777.

Nadler, A. 2004. Relations between soil and tree stem water content and bulk electrical conductivity under salinizing irrigation. Soil Sci. Soc. Am. J. 68, 779-783.

Navarro, A., Bañón, S., Conejero, W., Sánchez-Blanco, M.J., 2008. Ornamental characters, ion accumulation and water status in Arbutus unedo seedlings irrigated with saline water and subsequent relief and transplanting. Environ. Exp. Bot. 66, 362371.

Niu, G., Starman, T., Byrne, D., 2013. Responses of growth and mineral nutrition of garden roses to saline water irrigation. HortScience 48, 756-761.

Oron, G., DeMalach, Y., Gillerman, L., David, I., Lurie, S., 2002. Effect of water salinity and Irrigation Technology on yield and Quality of pears. Biosyst. Engin. 81, 237 247.

Parida, A.K., Das, A.B., 2005. Salt tolerance and salinity effects on plants: a review. Ecotox. Environ. Safe 60, 324-349. 
Pasternak, D., Nerd, A., 1995. Research and utilization of halophytes in Israel. Halophytes and biosaline agriculture, 325-348.

Rhoades, J.D., Manteghi, N.A., Shouse, P.J., Alves, W.J., 1989. Soil electrical conductivity and soil salinity: new formulations and calibrations. Soil Sci. Soc. Am. J. $53,433-439$.

Robinson, D.A., Gardner, C.M.K., Cooper, J.D., 1999. Measurement of relative permittivity in sandy soils using TDR, capacitance and theta probes: Comparison, including the effects of bulk soil electrical conductivity. J. Hydrol. (Amst.) 223,198211.

Rosenbaum, U., Huisman, J.A., Vrba, J., Vereecken, H., Bogena, H.R., 2011. Correction of temperature and electrical conductivity effects on dielectric permittivity measurements with ECHO sensors. Vadose Zone J. 10, 582-593.

Sánchez-Blanco, M.J., Ferrández, T., Morales, M.A., Morte, A., Alarcón, J.J., 2004. Variation in water status, gas exchange, and growth in Rosmarinus officinalis plants infected with Glomus deserticola under drought conditions. J. Plant Physiol. 161: 675-682.

Santos, C.V., 2004. Regulation of chlorophyll biosynthesis and degradation by salt stress in sunflower leaves. Sci. Hortic. 103, 93-99.

Scoggins, H. L., van Iersel, M.W., 2006. In situ probes for measurement of electrical conductivity of soilless substrates: Effects of temperature and substrate moisture content. HortScience 41, 210-214.

Seyfried, M.S., Grant, L.E., 2007. Temperature effects on soil dielectric properties measured at $50 \mathrm{MHz}$. Vadose Zone J. 6, 759-765.

Seyfried, M.S., Murdock, M.D., 2004. Measurement of soil water content with a $50 \mathrm{MHz}$ soil dielectric sensor. Soil Sci. Soc. Am. J. 68, 394-403.

Shannon, M.C., Grieve, C.M., 1999. Tolerance of vegetable crops to salinity. Sci. Hortic. 78, 5-38.

Song, J. Q., Fujiyama, H., 1998. Importance of Na content and water status for growth in Na-salinized rice and tomato plants. Soil Sci. Plant Nutr. 44, 197-208.

Tanji, K., Grattan, S., Grieve, C., Harivandi, A., Rollins, L., Shaw, D., Wu, L., 2008. Salt management guide for landscape irrigation with recycled water in coastal southern California: A comprehensive literature review. 
Torres, A.P., Mickelbart, M.V., Lopez, R.G., 2010. Leachate Volume Effects on pH and Electrical Conductivity Measurements in Containers Obtained Using the Pour-through Method. HortTechnology 20, 608-611.

Treder, J., Nowak, J., 2001. The effect of irrigation frequency on growth, flowering and stomatal conductance of osteospermum 'Denebola'and New Guinea impatiens' Timor'grown on ebb and-flow benches. Acta Agrobot. 54, 59-68.

Valdés, R., Miralles, J., Ochoa, J., Sánchez-Blanco, M.J., Arias, S.B., 2012. Saline reclaimed wastewater can be used to produce potted weeping fig (Ficus benjamina L.) with minimal effects on plant quality. Span. J. Agric. Res. 10, 1167-1175.

Valdés, R., Miralles, J., Ochoa, J., Franco, J.A., Sánchez-Blanco, M.J., Bañón, S., 2012. Prueba de sondas para medir conductividad y humedad del sustrato en maceta en condiciones salinas. Actas del XI Simposio Hispano-Portugués de Relaciones Hídricas en las Plantas, 222-225.

Valdés, R., Miralles, J., Franco, J.A., Sánchez-Blanco, M.J., Bañón, S., 2013. Evaluación de la salinidad del sustrato usando la conductividad eléctrica del medio en la producción de hortensia en maceta. VII Congreso Ibérico de Agroingeniería y Ciencias Hortícolas, Del 26 al 29 de agosto 2013.

Valdés, R., Alcaraz, M.S., Franco, J.A., Sánchez-Blanco, M. J., S. Bañón, S., 2014a. Programación del riego de geranio con agua salina utilizando sensores de conductividad eléctrica y humedad del suelo. I Symposium nacional de ingeniería hortícola "La Agromótica en la Horticultura" Actas de horticultura n 64.

Valdés, R., Miralles, J., Ochoa, J., Sánchez-Blanco, M.J., and Bañón, S., 2014b. The number of emitters alters salt distribution and root growth in potted gerbera. HortScience 49, 160-165.

Valdés, R. Miralles, J. Franco, J.A., Sánchez-Blanco, M.J. Bañón, S., 2014c. Using soil bulk electrical conductivity to manage saline irrigation in the production of potted poinsettia. Sci. Hortic. 170, 1-7.

Van Der Laan, M. , Stirzaker, R.J., Annandale, J.G., Bristow, K.L., Du Preez, C.C., 2011. Interpretation of electrical conductivity measurements from ceramic suction cups, wetting front detectors and ECH20-TE sensors. S. Afr. J. Plant Soil 28, 244-247.

Veatch-Blohm, M. E., Sawch, D., Elia, N., Pinciotti, D., 2014. Salinity tolerance of three commonly planted narcissus cultivars. HortScience 49, 1158-1164.

Villarino, G. H., Mattson, N. S., 2011. Assessing tolerance to sodium chloride salinity in fourteen floriculture species. HortTechnology 21, 539-545. 
Wang, Y. T., 1998. Impact of salinity and media on growth and flowering of a hybrid Phalaenopsis orchid. HortScience, 33, 247-250.

Wong, M., 2005. Salinity effects in nursery and landscape plants. Soil. Crop. Manag., 3 p. Cooperative Extension Service University of Hawai'i at Manoa.

Wright, R.D., 1986. The pour-through nutrient extraction procedure. HortScience 21, 227 229.

Yadav, S., Irfan, M., Ahmad, A., Hayat, S., 2011. Causes of salinity and plant manifestations to salt stress: a review. J. Environ. Biol. 32, 667-685. 


\section{Chapter 5}

\section{The number of emitters alters salt distribution and root growth in potted gerbera}

R. Valdés ${ }^{1}$, J. Miralles ${ }^{1}$, J. Ochoa ${ }^{1}$, M. J. Sánchez-Blanco ${ }^{2,3}$ and S. Bañón ${ }^{1,2}$

${ }^{1}$ Departamento de Producción Vegetal. Universidad Politécnica de Cartagena. Cartagena, Spain

${ }^{2}$ Unidad Asociada de Horticultura Sostenible en Zonas Áridas, CEBAS-Universidad Politécnica de Cartagena, Cartagena-Murcia, Spain

${ }^{3}$ Centro de Edafología y Biología Aplicada del Segura-CSIC, Murcia, Spain

Article reference:

Valdés, R., Miralles, J., Ochoa, J., Sánchez-Blanco, M. J., Bañón, B., 2014. The number of emitters alters salt distribution and root growth in potted gerbera. HortScience 49, 160165 .

Year 2013:

Impact factor: 0.855

Category: Horticulture

Category ranking 2013: (12/33)

Quartile in category: Q2 


\begin{abstract}
Potted gerberas were grown in a greenhouse with one, two or four emitters $\left(1.2 \mathrm{~L} \mathrm{~h}^{-}\right.$ $\left.{ }^{1}\right)$ per pot and irrigated with water of two levels of salinity $\left(1.5 \mathrm{dS} \mathrm{m}{ }^{-1}\right.$ and $\left.3 \mathrm{dS} \mathrm{m}^{-1}\right)$. All pots received the same volume of water. The aim was to determine whether the number of emitters per pot affects the distribution of roots and salts in the substrate (100\% coconut fiber). We determined the electrical conductivity (EC) distribution at three different heights (upper, middle and lower). We also studied the roots and EC horizontal distribution in four quadrants (SE, SW, NW, NE). Shoot growth, leaf damage, plant water status and photochemical capacity of photosystem II were also studied. Two or four emitters per pot reduced the leaching fraction compared with that observed with one emitter, improving both the amount and homogeneity of substrate moisture. In the two saline conditions used, the salt concentration in the substrate was irregular both vertically and horizontally, and the presence of roots in the horizontal quadrant sides was heterogeneous. Both these behaviors decreased as the number of emitters per pot increased. Root growth was weakly related with the soluble salt content in the root zone. When saline water is used, two emitters per pot are to be recommended because the difference between using two and four emitters were very slight. The use of only one emitter reduced shoot and root growth and encouraged salt damage to leaves.
\end{abstract}

Keywords: electrical conductivity, salinity, irrigation, floriculture, coconut fiber

\title{
1. Introduction
}

Irrigating with saline water leads to the accumulation of salt in the root zone, which reduces plant size and growth, alters plant development and causes leaf damage. These effects are more pronounced in container-grown crops, where the growing medium is more limited than in the ground, and, as a result, the aesthetic value of ornamental plants is reduced.

Over the last twenty five years, numerous studies have been conducted to improve the irrigation of potted plants. Many of these studies have focused on the effects of different irrigation methods and systems on the accumulation and distribution of salts and roots in the more common substrates, taking into consideration different fertilizer sources and rates (Argo and Biernbaum, 1994, 1995; Morvant et al., 1997). Progress has also been 
made in scheduling irrigation (Million et al., 2007); however, few studies have compared different ways of applying water over the surface of the substrate. Drip irrigation is generally thought to be a very efficient irrigation technique (Wang et al., 2011), and is the most widely used method for potted plant production. The basic concept underlying drip irrigation is to keep a bulb of soil moist so that roots can absorb water. The volume and shape of the wet bulb irrigated by each emitter are a function of the characteristics of the substrate (texture and hydraulic conductivity) and the discharge rate of the emitter (Awulachew et al., 2009). However, the number of water emission points over the substrate surface may also have an influence. Drip irrigation usually uses one emitter per pot for small containers, and very few published papers have studied the effect on growth and variations of roots and salts in the root ball when two or more emitters per pot are used. Ondrasek et al. (2008) reported the position of the emitters in the pot could strongly affect the moisture and salt distribution in the substrate.

Our hypothesis was that applying the same volume of water to pots using more than one emitter may influence the retention and diffusion of moisture in the substrate and, as a consequence, the distribution of salts and roots. To verify this coconut fiber-grown gerbera were irrigated with one, two and four emitters per pot under two levels of salinity (control or saline irrigation) during a spring-summer growing season, determining the effects on substrate and leachate EC, root growth, shoot growth, leaf damage, plant physiological status and leaching fraction.

\section{Materials and methods}

\subsection{Plant material and growing conditions}

Seedlings of Gerbera hybrid cv. Triana were transplanted into $3.75 \mathrm{~L}$ pots $(20 \mathrm{~cm}$ upper internal diameter and height $18 \mathrm{~cm}$ ) containing 100\% coconut fiber substrate (Projar Professional Cocopeat, Projar, S.A. Valencia, Spain). The substrate fill height was $16 \mathrm{~cm}$. The experiment took place in a greenhouse with a semicircular cover $(12 \mathrm{~m}$ length $\times 7 \mathrm{~m}$ width, $3 \mathrm{~m}$ height at the side and $4.5 \mathrm{~m}$ at the center) located at the Agricultural Experimental Station of the Polytechnic University of Cartagena (Cartagena, Spain). The top part was covered with polyethylene (PE) film and green shading screen (50\% shade). The sides were covered with PE film and anti-aphid mesh; the PE film could be rolled up for ventilation. The front and the back were covered with anti-aphid mesh. The pots were 
introduced into white pots $(\phi 24 \mathrm{~cm}) \mathrm{kept}$ in place in holes $(21 \mathrm{~cm} \times 21 \mathrm{~cm})$ in a metal grid made of corrugated bars ( $8 \mathrm{~mm}$ diameter), $80 \mathrm{~cm}$ off the ground. This experiment was conducted from the first week of Mar. 2012 to the second week of Sept. 2012.

The irrigation system used pressure-compensating and anti-drain emitters, which emit 1.2 liters of solution per hour (Netafim Ltd. Corporate Headquarters, Tel Aviv, Israel). The emitters used were tested for homogeneity before the experiment started (the water flow varied between 1.16 and $1.24 \mathrm{~L} \mathrm{~h}^{-1}$ ). The emitters were attached to a tube (60 $\mathrm{cm} \times 4 \mathrm{~mm}$ ) and were inserted into the substrate by means of a plastic straight arrow. The irrigation system was controlled by a system similar to that described by Nemali and van Iersel (2006) but using a CR1000 data logger which controlled the water pumps through an Agrónic 4000 (Sistemes Electrònics PROGRÉS, S. A., Bellpuig, Spain). The pumps were connected to $250 \mathrm{~L}$ tanks containing the irrigation solutions. The soil moisture level was measured by an EC5 Soil Moisture Probe (Decagon Devices, Ltd., Pullman, WA) placed in the east-facing part of the substrate at an angle of approximately $45^{\circ}$, with the flat side perpendicular to the surface of the substrate. The data logger was programmed to collect data every minute from three EC5 probes per treatment, and to calculate the average every thirty minutes. The $\theta$ was obtained from the voltage readings of the soil moisture sensor using our own substrate-specific calibration $(\theta=3.6642 * \mathrm{mV}-0.355$; $r^{2}=0.98$ ) determined using the procedure described by Valdés et al. (2012). Fertilization was carried out by the irrigation head, and in all treatments nutrients were provided at constant concentrations in the irrigation water, containing $80 \mathrm{~N}-17.5 \mathrm{P}-66.4 \mathrm{~K}(\mathrm{ppm})$ at $\mathrm{pH}$ 6. This nutrient solution was made by mixing $\mathrm{KNO}_{3}, \mathrm{NH}_{4} \mathrm{NO}_{3}, \mathrm{~K}_{2} \mathrm{HPO}_{4}$ and $\mathrm{HNO}_{3}$. The addition of fertilizers increased the EC by approximately $0.5 \mathrm{dS} \mathrm{m} \mathrm{m}^{-1}$.

The temperature and relative humidity were measured continuously during the experiment by a data logger (HOBO H08-004-02, MicroDAQ. com, Ltd., Contoocook, $\mathrm{NH}$, USA). The average air temperature in the greenhouse was $8.3^{\circ} \mathrm{C}$ (minimum), $25.7^{\circ} \mathrm{C}$ (average) and $45.2{ }^{\circ} \mathrm{C}$ (maximum); minimum relative humidity was $22.4 \%$, and the maximum $100 \%$, with a mean of $65.5 \%$.

\subsection{Irrigation treatments}

Six treatments resulted from irrigating with one, two or four emitters per pot under non-saline $\left(1.5 \mathrm{dS} \mathrm{m}^{-1}\right)$ and saline conditions $\left(3 \mathrm{dS} \mathrm{m}^{-1}\right)$. The emitters were inserted in the 
centre of the upper part of the four quadrants of the top circle of substrate (southeast [SE], southwest [SW], northwest [NW] and northeast [NE]). When only one emitter was used, it was placed in the SE quadrant; when two emitters were used, they were placed in the SE and NW quadrants. In the case of four emitters, they were placed in each of the four quadrants (Picture 1). The treatments started the first week of Apr. 2012 (four weeks after transplant, when the establishment phase had finished). Salinity took the form of sodium chloride added to the base nutrient solution of each tank.
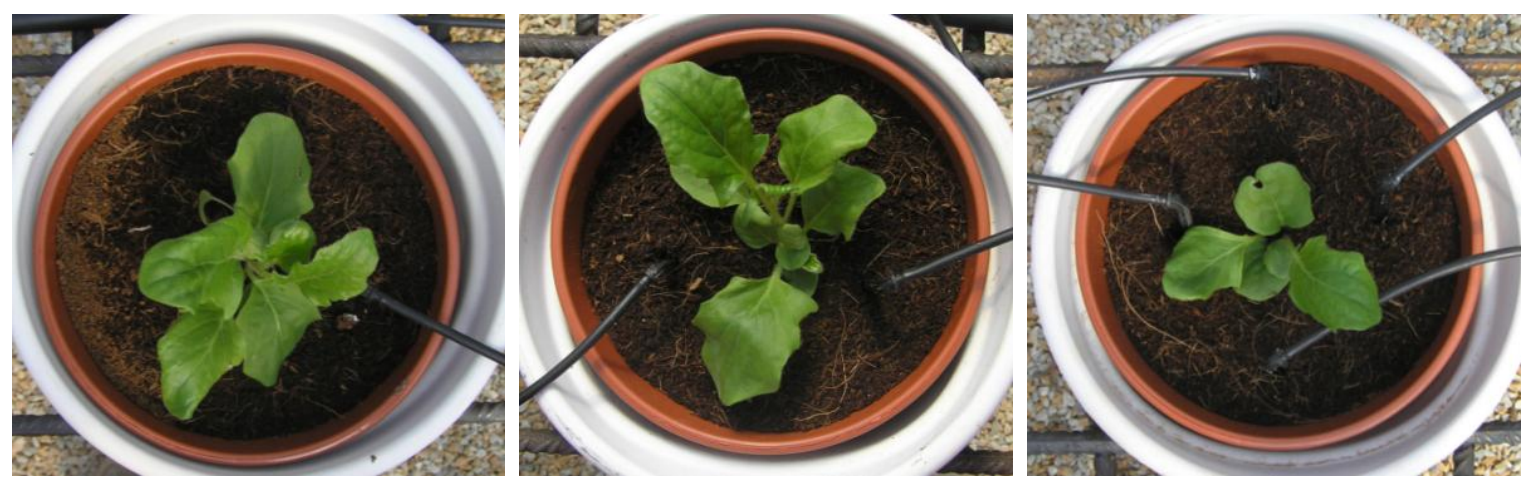

Picture 1. The position of the emitters for different treatments. From left to right one, two and four emitters.

For all treatments, the irrigation system was triggered when the average $\theta$ of the treatment with one emitter and $1.5 \mathrm{dS} \mathrm{m}^{-1}$ reached the threshold of $40 \%$ by volume. Hence, the irrigation frequency was the same for all treatments. All irrigation treatments were based on this treatment because it is the most frequently used. Furthermore, we started with the hypothesis that saline irrigation would increase the leaching fraction (due to the decrease in water consumption by the plant), while any increase in the number of emitters would increase consumption (wetter substrate), which would lead to an intermediate level of leaching.

The volume of water applied in each irrigation event was based on the duration of the event, which, in the case of one emitter, produced a leaching fraction of about $15 \%$ at EC $1.5 \mathrm{dS} \mathrm{m}^{-1}$ (a normal leaching fraction in this treatment). The irrigations carried out with two emitters lasted half of the time used for one emitter and when four emitters were used the time was a quarter of the time used for one emitter. 
Water consumption was calculated by measuring the water applied to the pots, so that in each treatment three $1.5 \mathrm{~L}$ plastic bottles containing the emitter or emitters were used.

From time to time, the volume of water collected in the bottles was measured in each treatment, and the sum of all these measurements was taken as the total amount of water applied. The mean quantity of water applied in the six treatments was $50.31 \pm 1.08 \mathrm{~L}$ per pot, which is slightly below the theoretical consumption calculated for the number of irrigation events and the duration of the same $(50.67 \mathrm{~L})$.

\subsection{Measurements}

The leaching fraction and leachate EC were measured in five pots of each treatment. The leachate was collected weekly throughout the study period in plastic containers and measured gravimetrically. The leachate EC was measured immediately after collection using an EC meter (Dist® 6, Hanna Instruments S.L., Eibar, Spain). The leaching fraction was quantified as the volume of solution leached from the pot divided by the total solution applied.

At the end of the experiment, the shoot growth, root growth and leaf damage were determined in six plants per treatment. To calculate the shoot dry weight (DW), the plant parts were placed in a natural convection bacteriological oven (model 2002471, JP Selecta SA, Barcelona, Spain) at $60{ }^{\circ} \mathrm{C}$ until constant weight was reached. Finally, the dry weight was determined by weighing with a GRAM ST precision balance (sensitivity of $10 \mathrm{mg}$ up to 1200 g, Gram Precision SL, Barcelona, Spain). The root growth index (RGI) was calculated as a percentage of roots for each one of the four quadrant sides of the root ball. Four photographs were taken of the plant roots, and the percentage of root area in the root ball sides (horizontal quadrants) was calculated with the image analysis software for plant disease quantification ASSESS 2.0 (University of Manitoba, Winnipeg, Canada) (Picture 2). To evaluate the damage caused by leaf necrosis, a leaf damage index (LDI) was adapted to the damage observed in the experiment. The LDI was calculated as the number of leaves with blades burned $25-75 \%$ multiplied by 0.5 plus the number of leaves with blades burned more than $75 \%$, dividing the result by the total number of leaves. Before choosing this index, we checked that its application to our plants properly reflected the level of salt damage in the leaves of several treatments. 


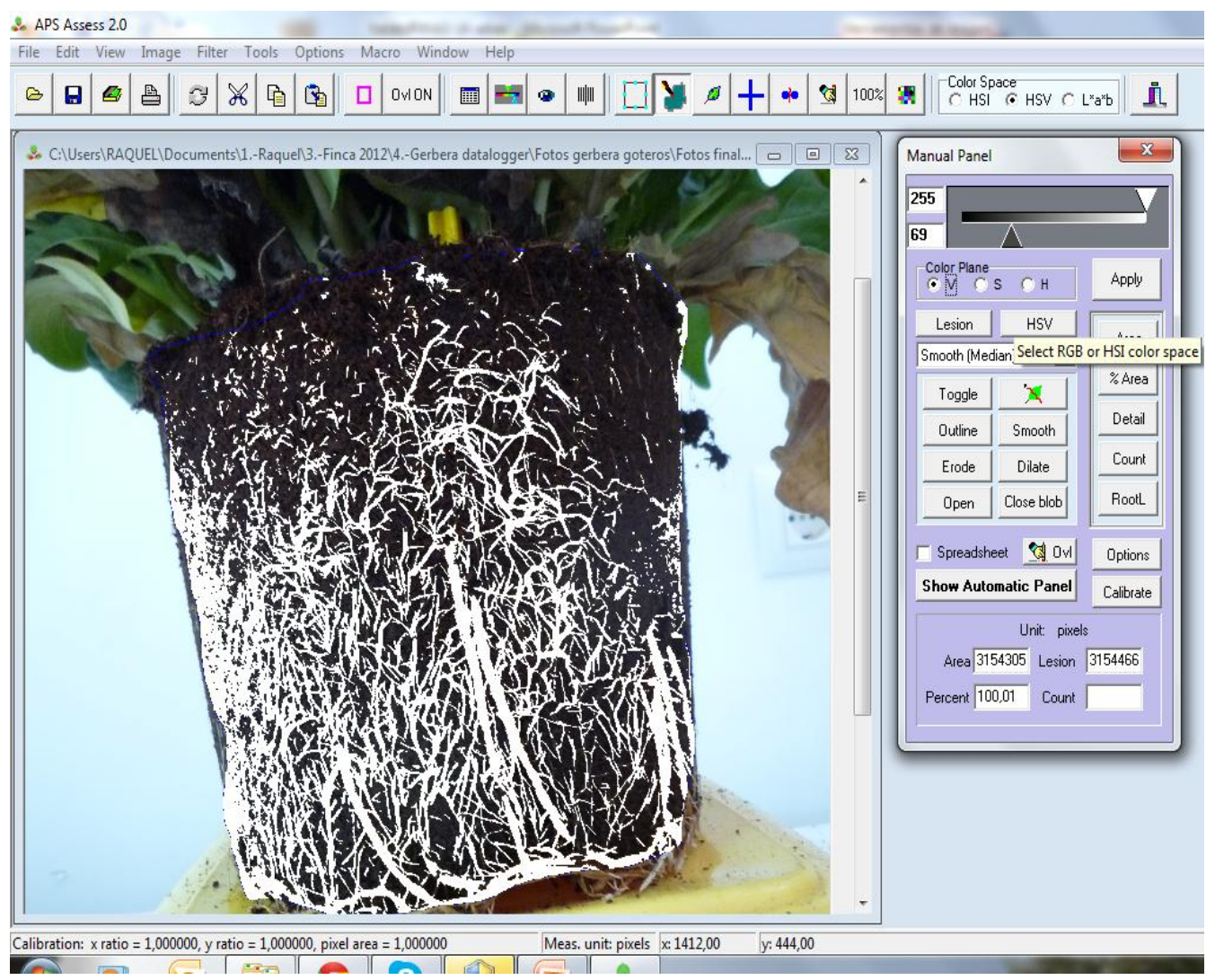

Picture 2. Measurement of roots with the image analysis software ASSESS 2.0.

To ascertain the physiological status of plants, the leaf water potential $\left(\Psi_{1}\right)$, osmotic potential $\left(\Psi_{\mathrm{o}}\right)$ and pressure potential $\left(\Psi_{\mathrm{p}}\right)$, net photosynthesis rate $\left(P_{\mathrm{n}}\right)$ and chlorophyll fluorescence were measured. $\Psi_{1}$ was estimated using a Scholander pressure chamber (Soil Moisture Equipment Co, Santa Barbara, CA, USA), for which leaves were enclosed in a plastic bag and sealed in the chamber within $20 \mathrm{~s}$ of collection and pressurized at a rate of $0.02 \mathrm{MPa} \mathrm{s}^{-1}$. Leaves from the $\Psi_{1}$ measurements were frozen in liquid nitrogen $\left(-170{ }^{\circ} \mathrm{C}\right)$ and stored at $-30{ }^{\circ} \mathrm{C}$. After thawing, the sap was extracted from the sample by means of a small press and placed on a filter paper disc in the osmometer chamber and $\Psi_{\mathrm{o}}$ values were measured using a WESCOR 5520 vapour pressure Osmometer (Wescor Inc., Logan, UT, USA). $\Psi_{\mathrm{p}}$ was estimated as the difference between $\Psi_{1}$ and $\Psi_{\mathrm{o}}$ for each time. The net photosynthesis rate was measured using a CIRAS-2 Portable Photosynthesis System (PP Systems, Amesbury, MA). The air flow rate through the cuvette was $200 \mathrm{~mL} \mathrm{~min}^{-1}$ with a $\left[\mathrm{CO}_{2}\right]$ of $350 \mu \mathrm{mol} \mathrm{mol}^{-1}$, the air temperature was $20^{\circ} \mathrm{C}$, the vapour pressure deficit was $1.6 \mathrm{kPa}$, and the photosynthetic photon flux $1500 \mu \mathrm{mol} \mathrm{m} \mathrm{m}^{-2}$. Chlorophyll fluorescence was measured using a Pulse Modulated Fluorimeter FMS-2 (Gomensoro Scientific Instrumentation, S.A., Madrid, Spain). The method and parameters determined were those 
described by Miralles et al. (2011). All physiological measurements were taken at midday in six plants per treatment at the end of the experiment.

\subsection{Distribution of salt and $\mathrm{pH}$ in substrate}

At the end of the experiment, the shoot of the plant was removed, and the pot and root ball were placed in a horizontal freezer (Zanussi ZFC639WAP, Electrolux Home Products, Madrid, Spain). After 24 hours at $-25^{\circ} \mathrm{C}$ the root balls were taken out and sliced into upper, middle and lower thirds. Each third was divided into four parts according to horizontal orientation - southeast (SE), southwest (SW), northwest (NW) and northeast (NE) - resulting in a total of twelve pieces per root ball. The frozen root ball was then cut with a toothed saw (Picture 3). Each piece was saturated with distilled water, from which the major roots were removed, according to Camberato et al. (2009). After extraction, the $\mathrm{EC}$ and $\mathrm{pH}$ of the extract were measured using multirange equipment (Hanna Instruments$8633 \mathrm{~N}$ ) and the $\mathrm{pH}$ was measured with a portable $\mathrm{pH}$-meter (Hanna Instruments-98150). Three measurements were made for each piece, and four root balls were used from each treatment.

\subsection{Statistical analysis and experimental design}

The experimental design was a randomized complete block with two blocks of ten plants per treatment. In each treatment, one pot (or plant) was a replicate. A two-way analysis of variance (ANOVA) was used to test the effects of two factors (water salinity and the number of emitters per pot) and their interaction on the parameters studied. When interaction between factors was significant, a one-way ANOVA was used for each factor. Means were separated by the least significant difference test at $P<0.05$. All statistical analyses were performed using Statgraphics Plus for Windows (Manugistics Inc., Rockville, MD). A regression analysis was made between RGI and substrate EC using SigmaPlot 10.0 (Systat Software Inc., San Jose, CA). Ratios and percentages were arcsine $(\mathrm{x})^{1 / 2}$ transformed before statistical analysis to ensure homogeneity of variance. 


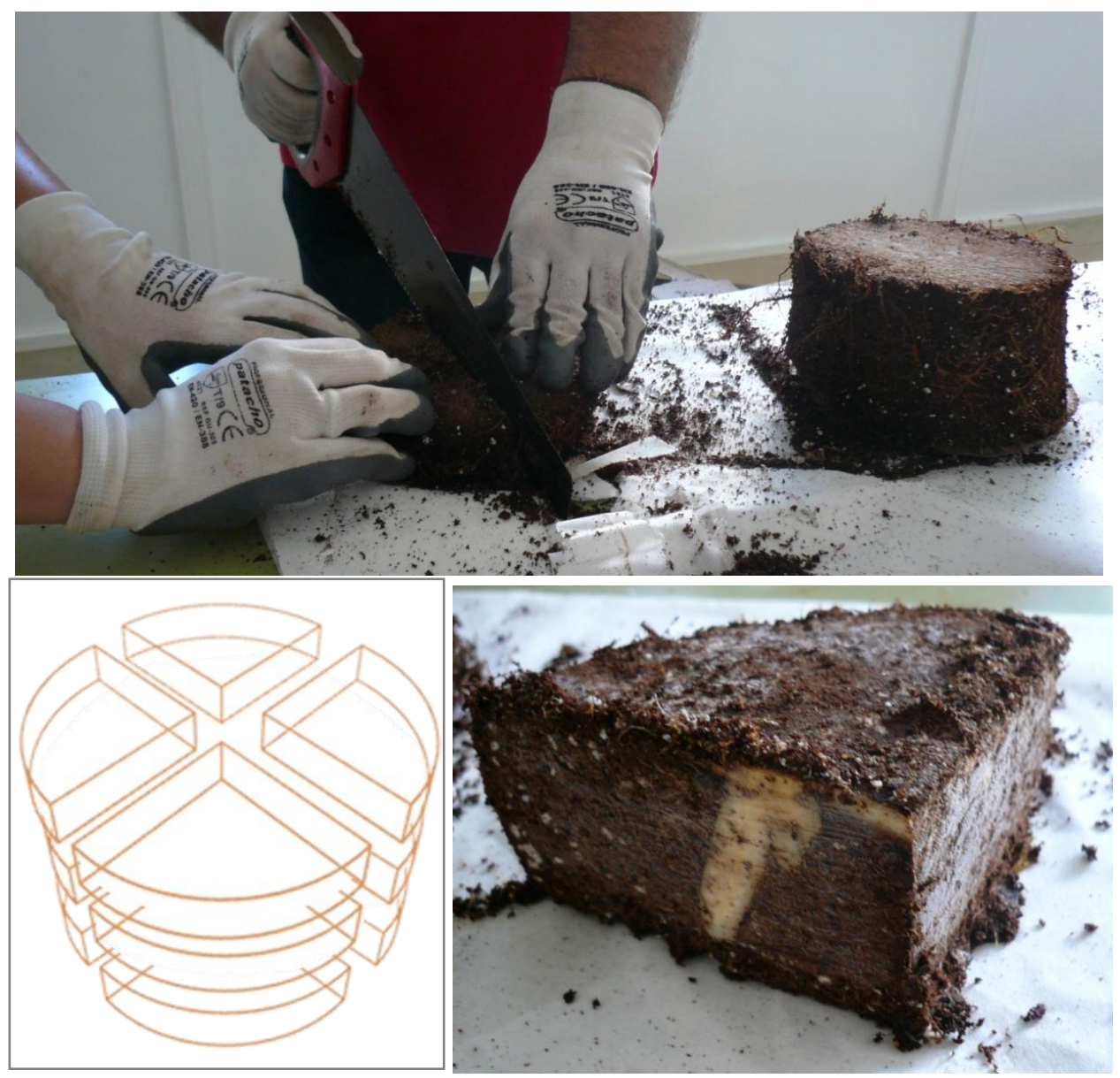

Picture 3. Details of slicing of the root ball.

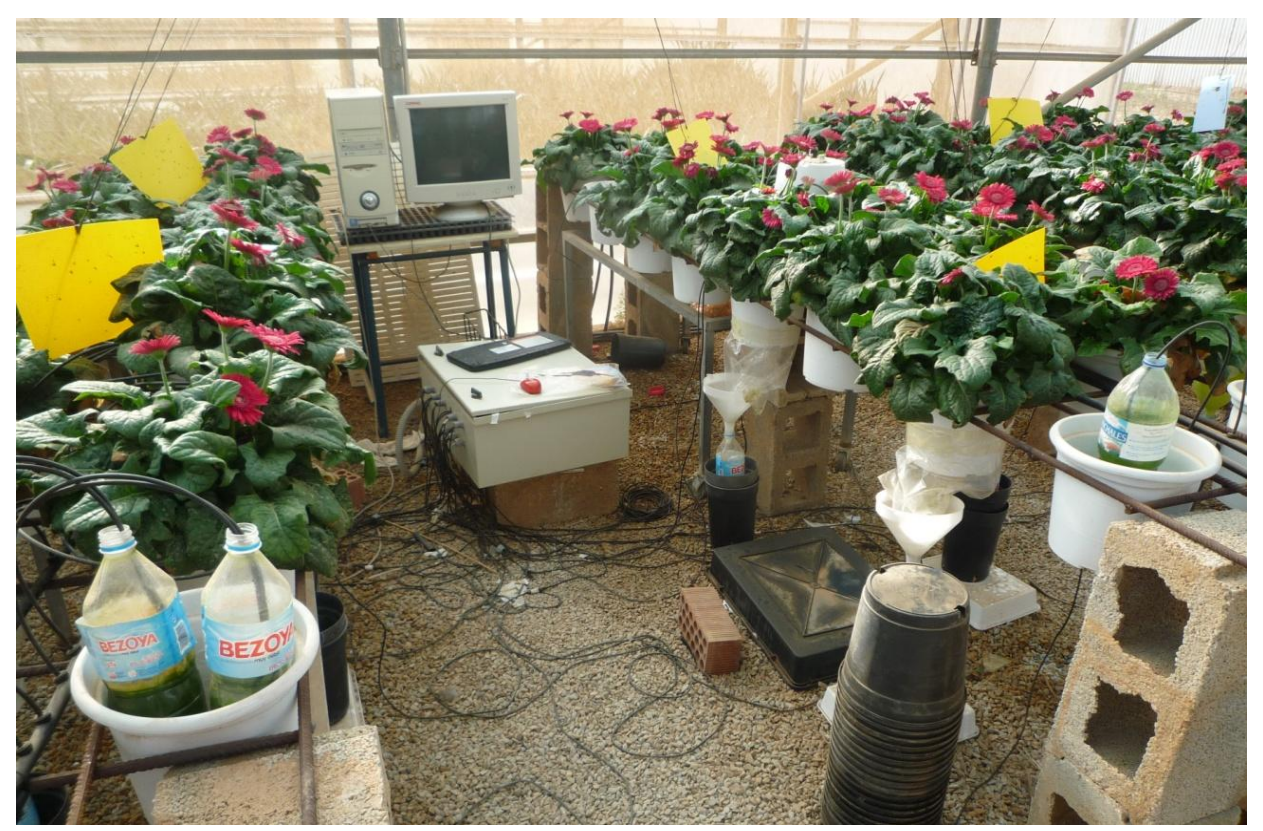

Picture 4. An overview of the greenhouse, which shows tables for different treatments and data logger. 


\section{Results and discussion}

\subsection{Shoot growth, leaf damage and number of inflorescences}

The analysis of variance applied to the shoot DW and leaf damage index (LDI) pointed to a significant relationship between salinity and the number of emitters per pot, indicating that the response to emitter treatments differed for the two saline conditions studied (Table 1). However, a non-significant interaction between salinity and the number of emitters in the number of inflorescences per plant was observed. The number of emitters did not alter the shoot DW of the plants in the control conditions; however, using two or four emitters per pot increased shoot DW in saline conditions by about $12 \%$ compared with one emitter (Table 1). The saline treatment reduced the shoot DW compared with the control. The gerbera plants irrigated with saline solution had higher LDI scores than those irrigated with control water (Table 1), diminishing their visual quality. Two and four emitters per pot reduced the negative effect of salinity on leaves (necrosis). No factor produced statistically significant changes in the number of inflorescences per plant, averaging about seven in all treatments (Table 2).

\subsection{Plant physiological status}

Plant physiological status was assessed by determining the water relations and photochemical capacity. All plants presented a high midday leaf water potential value, which indicates that they were well watered and that there were no osmotic effects (Table 2). Increased salinity of the irrigation water generally leads to lower leaf osmotic potentials (Niu and Cabrera, 2010), as was observed in our experiment (Table 2). A common effect of a decrease in leaf osmotic potential is an increase in leaf turgor in saline conditions (Cassaniti et al., 2012). In our case, salinized plants had a higher leaf turgor potential than the control plants, but, despite this, they showed only a slight reduction in shoot growth (Table 1). Salinity invariably leads to increased concentrations of some ions in the shoots of plants, which may directly affect plant growth through an osmotic effect (not observed in our plants). As regards the effect of the number of emitters per pot, only the use of four emitters caused a very slight increase in leaf water potential (0.05 MPa), whether the plants were irrigated with control solution or saline solution, while leaf turgor potential was not altered (Table 2). 
Neither the maximum quantum efficiency of photosystem II $(\mathrm{Fv} / \mathrm{Fm})$ nor the ratio between the apparent electron transport rate and net photosynthetic $\left(\mathrm{ETR} / P_{\mathrm{n}}\right)$ was modified by the two factors studied (Table 2). However, non-photochemical quenching (NPQ) increased as a result of salinity but to a lesser extent when two and four emitters were used (Table 1), indicating that in the salinized plants there was a greater thermal dissipation of excess absorbed energy (to prevent photosynthetic damage) than in the plants irrigated with control solution. In studies of the salt tolerance of different cultivars, the Fv/Fm ratio was not affected by salt, whereas NPQ increased in sensitive cultivars (Dionisio-Sese and Tobita, 2000).

Table 1. Effects of salinity and the number of emitters per pot on the parameters studied when interaction was significant.

\begin{tabular}{llrrr}
\hline \multirow{2}{*}{ Parameters } & Salinity & \multicolumn{3}{c}{ Number of emitters per pot } \\
\cline { 3 - 5 } & & \multicolumn{1}{c}{1} & \multicolumn{1}{c}{4} \\
\hline \multirow{2}{*}{ Shoot DW $(\mathrm{g})$} & Control & $66.61 \mathrm{a}$ & $65.49 \mathrm{a}$ & $68.14 \mathrm{a}$ \\
& Saline & $* 51.29 \mathrm{a}$ & $* 58.49 \mathrm{~b}$ & $* 57.90 \mathrm{~b}$ \\
Leaf damage index & Control & $14.36 \mathrm{a}$ & $15.12 \mathrm{a}$ & $15.72 \mathrm{a}$ \\
& Saline & $* 30.09 \mathrm{~b}$ & $* 24.83 \mathrm{a}$ & $* 25.98 \mathrm{a}$ \\
NPQ & Control & $1.50 \mathrm{a}$ & $1.56 \mathrm{a}$ & $1.50 \mathrm{a}$ \\
& Saline & $* 2.01 \mathrm{~b}$ & $* 1.68 \mathrm{a}$ & $* 1.69 \mathrm{a}$ \\
Leachate EC $\left(\mathrm{dS} \mathrm{m}{ }^{-1}\right)$ & Control & $2.05 \mathrm{a}$ & $4.02 \mathrm{~b}$ & $4.95 \mathrm{~b}$ \\
& Saline & $* 5.48 \mathrm{a}$ & $* 12.63 \mathrm{~b}$ & $* 13.86 \mathrm{~b}$ \\
Substrate EC $\left(\mathrm{dS} \mathrm{m}{ }^{-1}\right)$ & Control & $6.84 \mathrm{a}$ & $6.06 \mathrm{a}$ & $6.55 \mathrm{a}$ \\
& Saline & $* 13.48 \mathrm{~b}$ & $* 9.94 \mathrm{a}$ & $* 10.19 \mathrm{a}$ \\
Root growth index $(\%)$ & Control & $19.89 \mathrm{a}$ & $21.81 \mathrm{~b}$ & $25.42 \mathrm{~b}$ \\
& Saline & $* 12.51 \mathrm{a}$ & $* 16.56 \mathrm{~b}$ & $24.31 \mathrm{c}$ \\
& &
\end{tabular}

*indicates significant differences between the two levels of salinity, and different letters indicate significant differences among the number of emitters by least significant difference test $(\mathrm{P}<0.05)$. Control $\left(1.5 \mathrm{dS} \mathrm{m}^{-1}\right)$. Saline ( $\left.3 \mathrm{dS} \mathrm{m}^{-1}\right)$. NPQ, non-photochemical quenching; DW, dry weight; EC, electrical conductivity. 
Table 2. Effects of salinity and the number of emitters per pot on the parameters studied when the interaction between both factors was not significant.

\begin{tabular}{lrrrrrrr}
\hline \multirow{2}{*}{ Parameters } & \multicolumn{2}{c}{ Number of emitters per pot } & & \multicolumn{2}{c}{ Salinity } \\
\cline { 2 - 3 } & 1 & 2 & 4 & & Control & Saline \\
\hline Inflorescences per plant & $7.17 \mathrm{a}$ & $7.50 \mathrm{a}$ & $6.67 \mathrm{a}$ & & $7.45 \mathrm{a}$ & $6.78 \mathrm{a}$ \\
Leaf water potential $(\mathrm{MPa})$ & $-0.44 \mathrm{~b}$ & $-0.45 \mathrm{~b}$ & $-0.40 \mathrm{a}$ & & $-0.47 \mathrm{a}$ & $-0.39 \mathrm{~b}$ \\
Leaf osmotic potential $(\mathrm{MPa})$ & $-1.51 \mathrm{a}$ & $-1.52 \mathrm{a}$ & $-1.50 \mathrm{a}$ & & $-1.42 \mathrm{~b}$ & $-1.59 \mathrm{a}$ \\
Leaf turgor potential $(\mathrm{MPa})$ & $1.07 \mathrm{a}$ & $1.07 \mathrm{a}$ & $1.10 \mathrm{a}$ & & $0.95 \mathrm{a}$ & $1.21 \mathrm{~b}$ \\
Fv/Fm & $0.85 \mathrm{a}$ & $0.85 \mathrm{a}$ & $0.86 \mathrm{a}$ & & $0.85 \mathrm{a}$ & $0.85 \mathrm{a}$ \\
ETR/P & $16.21 \mathrm{a}$ & $15.77 \mathrm{a}$ & $15.02 \mathrm{a}$ & & $15.55 \mathrm{a}$ & $15.79 \mathrm{a}$ \\
Leaching fraction $(\%)$ & $21.19 \mathrm{~b}$ & $10.44 \mathrm{a}$ & $9.60 \mathrm{a}$ & & $9.94 \mathrm{a}$ & $17.54 \mathrm{~b}$ \\
Substrate $\mathrm{pH}$ & $5.72 \mathrm{a}$ & $5.60 \mathrm{a}$ & $5.50 \mathrm{a}$ & & $5.70 \mathrm{a}$ & $5.51 \mathrm{a}$
\end{tabular}

*Different letters indicate significant differences among the number of emitters per pot and between the two levels of salinity by least significant difference test $(\mathrm{P}<0.05)$. Control $(1.5 \mathrm{dS} \mathrm{m}$ $\left.{ }^{1}\right)$. Saline $\left(3 \mathrm{dS} \mathrm{m}^{-1}\right) . \mathrm{Fv} / \mathrm{Fm}$, the maximum quantum efficiency of photosystem II; ETR/Pn, the ratio between the apparent electron transport rate and net photosynthesis.

\subsection{Leaching fraction and leachate EC}

The leaching fraction was significantly affected by the number of emitters per pot and by salinity. Saline irrigation increased the leaching fraction (Table 2) because the plants grew more slowly (lower consumption) and because root water extraction was more difficult (osmotic effect of salt ions) despite the good appearance of the roots (no necrosis). In contrast, the number of emitters per pot reduced leaching, which was true in the two saline conditions studied (non-significant interaction). Irrigating with two or four emitters per pot decreased leaching by around half compared with one emitter (Table 2), while these two treatments caused similar leaching fraction. So, irrigation with two or four emitters led to a higher degree of water retention in the substrate, which implies greater homogeneity of the substrate water content than was obtained with one emitter. Leachate EC was significantly affected by the number of emitters per pot and salinity. Using two and four emitters per pot significantly increased leachate EC compared with the values obtained with one emitter (Table 1), especially in the saline treatment (significant interaction). Two and four emitters per pot had similar effects on leachate EC (Table 1). The greater leachate EC under two and four emitters seems to have been more related with 
the EC of the water applied and with the volume of water leached than with the growth of plants (leaf biomass) because substrate moisture at the time of irrigation was nearly always higher in these treatments than in the one emitter treatment (data not shown). Greater salinity implies greater leachate EC, as occurred here. As regards the volume of water leached, this was lower with two or four emitters due to the greater uniformity of substrate humidity. However, one emitter produced more concentrated salts around the emitter influence zone (Fig. 1C and D), and in the whole substrate (Table 1). So, two or four emitters could flush out more salts than one emitter, leading to a degree of channeling and lower wettability of some parts of the substrate where salts are accumulated, and only the portion of substrate near the emitter would be properly flushed out.

\subsection{Substrate EC and $p H$}

Mean substrate EC $\left(\mathrm{EC}_{\mathrm{S}}\right)$ significantly increased with salinity, while the opposite effect was observed as the number of emitters per pot increased, although this last effect was not observed when the plants were irrigated at $1.5 \mathrm{dS} \mathrm{m}^{-1}$ (interactive effect, see Table 1). Irrigating with two emitters per pot caused the same effects on substrate EC as irrigating with four (Table 1). These findings indicate the use of two or four emitters per pot encourages flushing out of the salts under saline conditions. We attribute this effect to the greater volume of substrate explored by the water applied because the water and salts extend more horizontally in a saturated substrate than in a drier substrate (De Rijck and Schervens, 1998). Consequently, a lower leaching fraction implies a greater amount of salts, an effect confirmed by the EC values recorded in the leachate (Table 1).

To study the effect of the number of emitters on the distribution of salts in the whole substrate a coefficient of variation $(\mathrm{CV})$ of the $\mathrm{EC}_{\mathrm{S}}$ was calculated between the twelve pieces extracted from each pot (Fig. 2). Overall, the salts were unevenly distributed in the substrate $(\mathrm{CV} \geq 20 \%)$. The control treatment led to a more heterogeneous distribution of salts than saline irrigation, except when four emitters per pot were used, because salt content variability in the root ball was attenuated by the number of emitters: the lower the salinity in the irrigation water, the greater the attenuation attained by two or four emitters.

Salinity, the number of emitters per pot and their interaction had no significant effects on substrate $\mathrm{pH}$ (Table 2). However, Ku and Hershey $(1991,1992)$ found a vertical $\mathrm{pH}$ gradient in potted geranium and poinsettia, while De Rijck and Schervens (1998) 
found very little variation in rockwool slabs. Any such variation is often associated with a lower $\mathrm{pH}$ in the bottom of the root ball, and is encouraged by low water alkalinity and high amounts of ammonium fertilizer (Argo and Fisher, 2002). In our trial, all treatments had a substrate $\mathrm{pH}$ of around 5.5 (Table 2), due to the effect of the nitric acid $\left(\mathrm{HNO}_{3}\right)$ which was continuously added to lower the $\mathrm{pH}$ of the irrigation solution.

\subsection{Vertical distribution of $E C_{S}$}

On the whole, the $\mathrm{EC}_{\mathrm{S}}$ at the end of the experiment was highest in the top layer (Fig. $1 \mathrm{~A}$ and B). Salt accumulation in the top part of the substrate is often associated with subirrigation than overhead irrigation (Kang and van Iersel, 2009; Rouphael and Colla, 2009). Other reports using drip irrigation showed the $\mathrm{EC}_{\mathrm{S}}$ to be higher in the upper layer than in the underlying layers (Ku and Hershey, 1992; Morvant et al., 1997; Million et al., 2007). In our case, increasing the number of emitters per pot slightly reduced the vertical stratification of salts in the substrate, probably because the up and down movement of water and salts was altered. This behaviour was most evident under the control irrigation with four emitters per pot (Fig. 1A). The higher EC of the top layer may have been due to evaporation between irrigation events since the evaporation of water from the substrate surface may be significant. Navarro et al. (2007) estimated that evaporation from the surface of the substrate in potted Arbutus unedo was about $30 \%$ of evapotranspiration, and Biernbaum et al. (1991) found that $30 \%$ to $60 \%$ of total water lost from a potted plant was caused by evaporation from the substrate surface. Evaporation from the substrate surface leads to the accumulation of salts at the top of the pot (Guttormsen, 1969). In our experiment we used coconut fiber as a substrate, which has better capillarity than most other commonly used potting substrates (Krishnamurthy et al., 2009). Our previous observations indicated that the coconut fiber surface dries quickly while the rest of the substrate remains wet. Probably, the wicking action of coconut fiber lifted moisture towards the higher part of the substrate, where evaporation was very rapid as a result of a high vapor pressure deficit (Rouphael and Colla, 2005). In this way, evaporation from the coconut fiber surface allowed salts to build up in the top part. Moreover, we used a drip irrigation system with emitters of $1.2 \mathrm{~L} \mathrm{~h}^{-1}$, so that water percolated slowly to the deeper layers, decreasing the downward movement of the salts. 

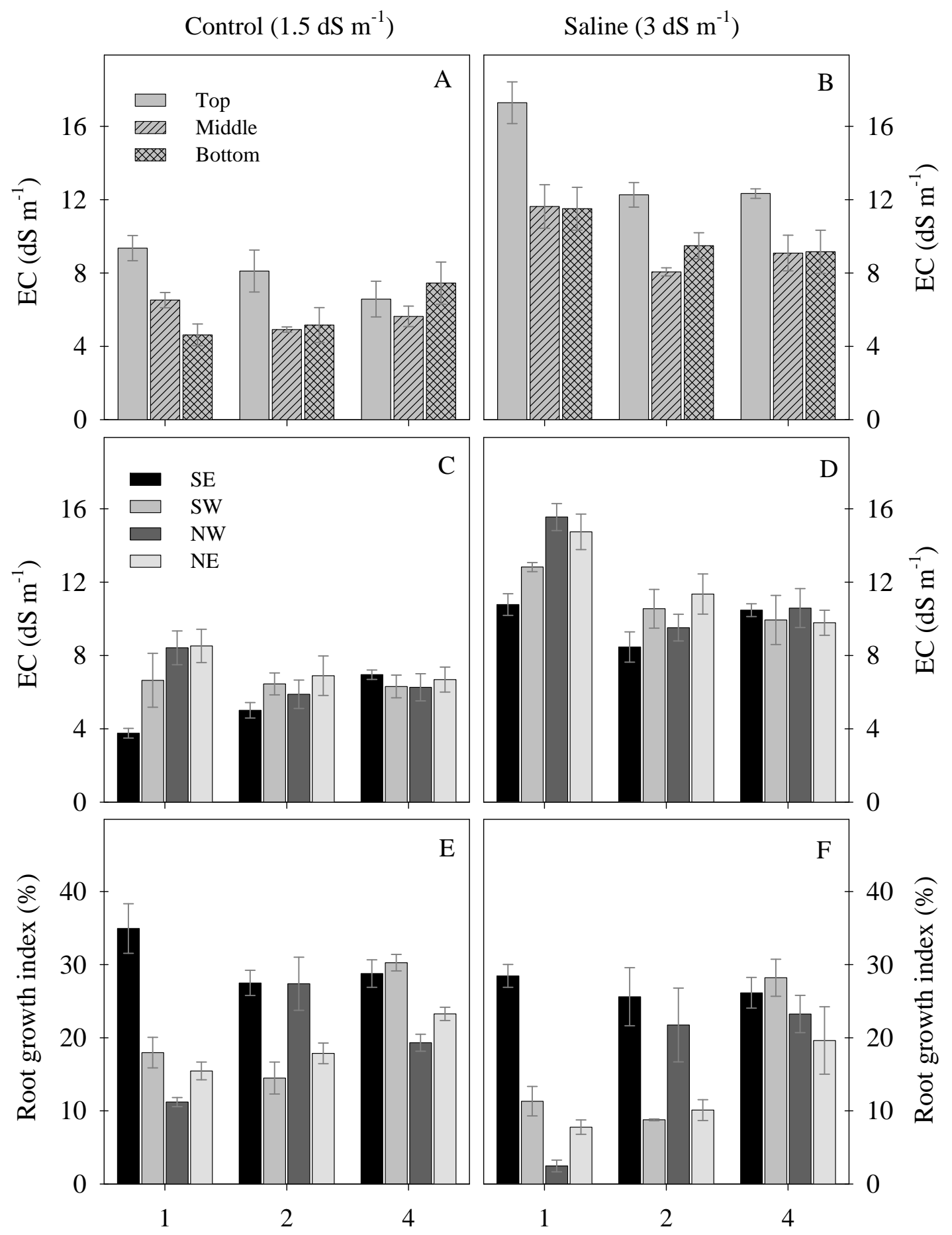

Number of emitters per pot

Figure 1. Electrical conductivity (EC) and root distribution in the root ball. A) Vertical EC gradient with an irrigation solution of $1.5 \mathrm{dS} \mathrm{m}^{-1}$, B) Vertical EC gradient with an irrigation solution of $3 \mathrm{dS} \mathrm{m}^{-1}$, C) Horizontal EC gradient with an irrigation solution of $1.5 \mathrm{dS} \mathrm{m}^{-1}, \mathrm{D}$ ) Horizontal EC gradient with an irrigation solution of $3 \mathrm{dS} \mathrm{m}^{-1}$, E) Horizontal root distribution with an irrigation solution of $1.5 \mathrm{dS} \mathrm{m}^{-1}, \mathrm{~F}$ ) Horizontal root distribution with an irrigation solution of 3 $\mathrm{dS} \mathrm{m} \mathrm{m}^{-1}$. Vertical bars show LSD at $\mathrm{P}<0.05$. 


\subsection{Horizontal distribution of $E C_{S}$}

The analysis of the distribution of EC among horizontal quadrants of the substrate (horizontal distribution) also showed a salt gradient. Irrigating with one emitter per pot led to the lowest $\mathrm{EC}_{\mathrm{S}}$ in the $\mathrm{SE}$ quadrant (Fig. 1C and D), where the emitter was placed, building up a wet bulb in this quadrant. As the wet bulb was often saturated, the irrigation solution spread more in the horizontal direction (De Rijck and Schervens, 1998; Ondrasek et al., 2008), displacing salts to the other quadrants. This behavior was observed with one emitter under both saline conditions studied, and was especially evident at $1.5 \mathrm{dS} \mathrm{m}^{-1}$. The horizontal $\mathrm{EC}_{\mathrm{S}}$ gradient was decreased by increasing the number of emitters per pot, independent of the level of salinity in the irrigation water. When two emitters per pot were used, the quadrants with an emitter tended to accumulate less salts than those without an emitter, while with four emitters per pot all quadrants had a similar salt content (Fig. 1C and D).

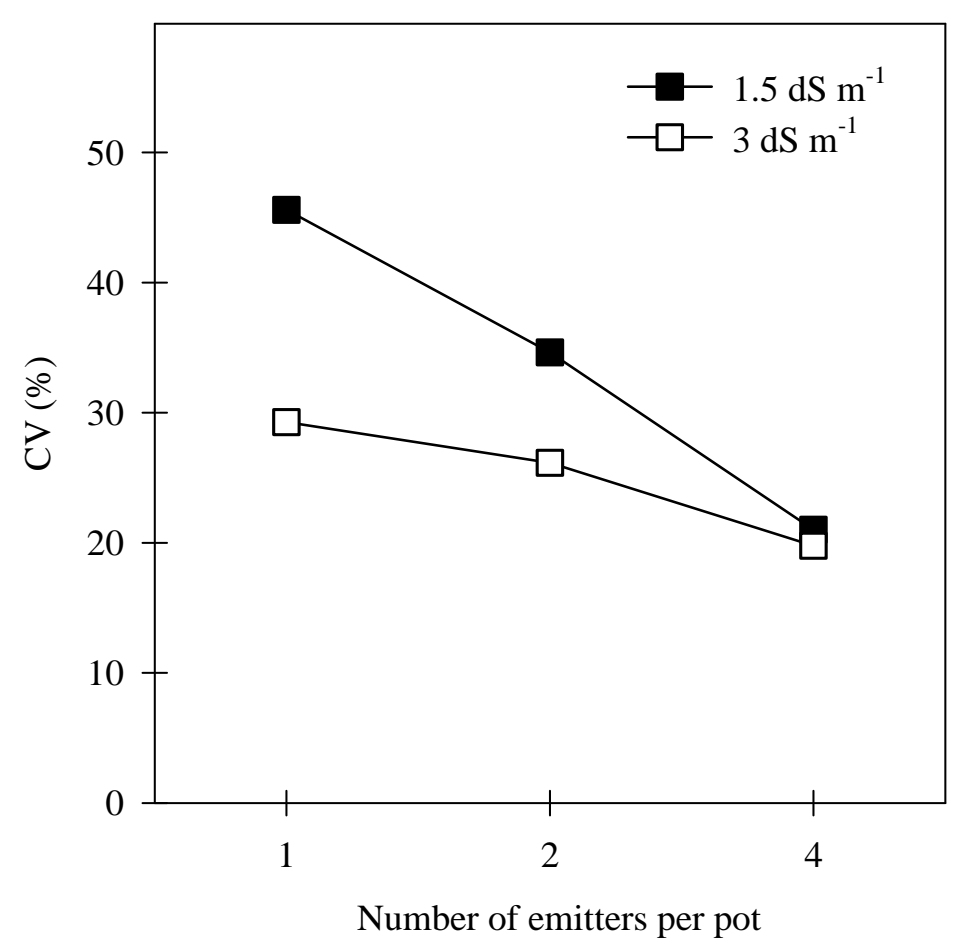

Figure 2. Coefficient of variation $(\mathrm{CV})$ of the substrate $\mathrm{EC}$ in the root ball for the six treatments studied. 


\subsection{Root growth and horizontal distribution of roots in root ball}

The root growth index (RGI) of gerbera depended on the number of emitters per pot and salinity: the index was reduced by salinity, while the opposite occurred with the number of emitters per pot (Table 1). The interaction between salinity and the number of emitters was the result of salinity having no effect on RGI when four emitters per pot were used. Several authors have noted that high $\mathrm{EC}_{\mathrm{S}}$ may inhibit root growth, with a reduction in the length and mass of roots (Argo and Biernbaum, 1995; Morvant et al., 1997; Shannon and Grieve, 1998). The ECs and RGI had a significant linear relationship (Fig. 3 ), suggesting that root growth was related to salt concentration in the root zone (RGI decreasing with increasing $\left.\mathrm{EC}_{\mathrm{S}}\right)$. However, this relationship was weak $\left(\mathrm{r}^{2}=0.37\right)$ because of the influence of moisture (Santamaria et al., 2003) and temperature (Drennan and Nobel, 1996) on root growth in the substrate. We found that the salts accumulated in the top layer, while the greatest part of the gerbera root system was in the lower layer.

The horizontal distribution of roots in the root ball showed similar behavior with both irrigation treatments, especially when one emitter was used (Fig. 1E and F). With one emitter per pot, the RGI was highest in the SE quadrant (where the emitter was placed), intermediate in the SW and NE quadrants, and lowest in the NW quadrant (furthest from the emitter). In this case, the quadrant with the lowest EC had the highest root growth (Fig. 1C and E). When two emitters per pot were used, the SE and NW quadrants (wettest) had a higher RGI than the SW and NE quadrants (least wet). Using four emitters per pot (one in each quadrant) RGI was higher in the south than in north (Fig. 1E and F), which could be related with the higher temperature in these quadrants (sunniest). 


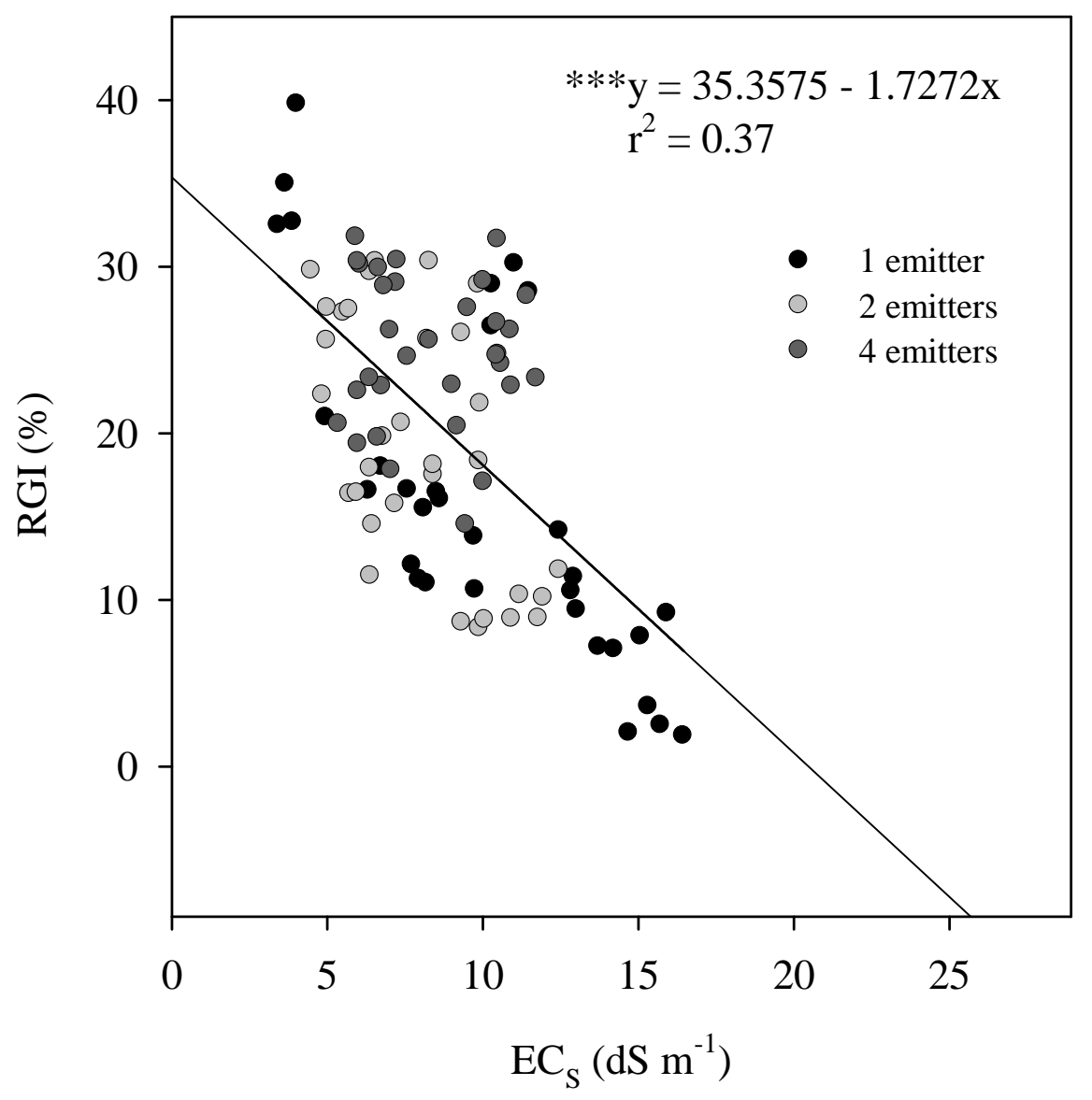

Figure 3. Regression analysis between root growth index (RGI) and substrate $\mathrm{EC}\left(\mathrm{EC}_{\mathrm{S}}\right)$.

\section{Conclusions}

Using more than one emitter per pot attenuated both the reduced aerial growth and leaf necrosis caused by salinity; two and four emitters having the same effect in this respect. Irrigating with two or four emitters per pot decreased the salt content and improved substrate wetting. Increasing the number of emitters increased the homogeneity of salt distribution in the substrate, because salts tended to increase around the wet bulb produced by the emitter. The presence of roots at the root ball side was weakly related with the soluble salts content of the root zone; it seems likely that root growth was mainly determined by the moisture content of the root zone. The effectiveness of using two or four emitters per pot was more evident under saline conditions. Under the conditions used in this study, we recommend irrigating with two emitters per pot, especially when the irrigation solution is saline. 


\section{Acknowledgements}

We are grateful for the financial aid received from the Ministerio de Economía y Competitividad and FEDER through the projects (AGL2011-30022-C02-1 and AGL201130022-C02-2).

\section{References}

Argo, W.R., Biernbaum, J.A., 1994. Irrigation requirements, root-medium $\mathrm{pH}$, and nutrient concentrations of easter lilies grown in five peat-based media with and without an evaporation barrier. J. Amer. Soc. Hort. Sci 119, 1151-1156.

Argo, W.R., Biernbaum, J.A., 1995. The effect of irrigation method, water-soluble fertilization, replant nutrient charge, and surface evaporation on early vegetative and root growth of poinsettia. J. Amer. Soc. Hort. Sci. 120, 163-169.

Argo, W.R., Fisher, P.R, 2002. Understanding pH management for container-grown crops. Greenhouse Grower.

Awulachew, S.B., Lemperiere, P., Tulu, T., 2009. Training manual on agricultural water management. Module 5: Irrigation methods. ILRI Publications Unit, Addis Ababa, Ethiopia.

Biernbaum, J.A., Argo, W., Yelanich, M., 1991. Effect of a pot cover on irrigation and fertilizer requirements and media nutrient stratification. HortScience 26, 764.

Camberato, D., Lopez, R., Mickelbart, M., 2009. pH and electrical conductivity measurements in soilless substrates. Purdue Univ. Ext. Serv. Bul. HO-237-W:1-6.

Cassaniti, C., Romano, D., Flowers, T.J., 2012. The response of ornamental plants to saline irrigation water, p. 131-158. In: García-Garizábal, I. and R. Abrahao (eds.). Ornamental Plants to Saline Irrigation Water. IN-TECH, Rijeka, Croatia.

De Rijck, G., Schrevens, E., 1998. Distribution of nutrients and water in rockwool slabs. Sci. Hortic. 72, 277-285.

Dionisio-Sese, M., Tobita, S., 2000. Effects of salinity on sodium content and photosynthetic responses of rice seedlings differing in salt tolerance. J. Plant Physiol. $157,54-58$.

Drennan, P.M., Nobel, P.S., 1996. Temperature infuences on root growth for Encelia farinosa (Asteraceae), Pleuraphis rigida (Poaceae), and Agave deserti (Agavaceae) under current and doubled $\mathrm{CO}_{2}$ concentrations. Am. J. Bot. 83, 133-139. 
Guttormsen, G., 1969. Accumulation of salts in the sub-irrigation of pot plants. Plant Soil 31, 425-438.

Kang, J.G., van Iersel, M.W., 2009. Managing fertilization of bedding plants: a comparison of constant fertilizer concentrations versus constant leachate electrical conductivity. HortScience 44, 151-156.

Krishnamurthy, K., Maheswari, C., Udayarani, R., Gowtham, V., 2009. Design and fabrication of coir pith prequetting machine. World Appl. Sci. J. 7, 552-558.

$\mathrm{Ku}$, C.S., Hershey, D.R., 1991. Leachate electrical conductivity and growth of potted poinsettia with leaching fractions of 0 to 0.4 . J. Am. Soc. Hortic. Sci. 116, 802-806.

$\mathrm{Ku}$, C.S., Hershey, D.R., 1992. Leachate electrical conductivity and growth of potted geranium with leaching fractions of 0 to 0.4. J. Amer. Soc. Hort. Sci. 117, 893-897.

Million, J., Yeager, T., Larsen, C., 2007. Water use and fertilizer response of azalea using several no-leach irrigation methods. HortTechnology 17, 21-25.

Miralles, J., Martínez, J.A., Franco, J.A., Bañón, S., 2011. Determining freezing injury from changes in chlorophyll fluorescence in potted oleander plants. HortScience 46, 895-900.

Morvant, J.K., Dole, J.M., Allen, E., 1997. Irrigation systems alter distribution of roots, soluble salts, nitrogen, and pH in the root medium. HortTechnology 7, 156-160.

Navarro, A., Bañon, S., Olmos, E., Sánchez-Blanco, M.J., 2007. Effects of sodium chloride on water potential components, hydraulic conductivity, gas exchange and leaf ultrastructure of Arbutus unedo plants. Plant Sci. 172, 473-480.

Nemali, K., van Iersel, M., 2006. An automated system for controlling drought stress and irrigation in potted plants. Sci. Hortic. 110, 292-297.

Niu, G., Cabrera, R.I., 2010. Growth and physiological responses of landscape plants to saline water irrigation - a review. HortScience 45, 605-1609.

Ondrasek, G., Romic, D., Romic, M., Tomic, F., Mustac, I., 2008. Salt distribution in peat substrate grown with melon (Cucumis melo L.). Acta Hortic. 779, 307-312.

Rouphael, Y., Colla, G.,2005. Growth, yield, fruit quality and nutrient uptake of hydroponically cultivated zucchini squash as affected by irrigation systems and growing seasons. Sci. Hort. 105, 177-195.

Rouphael, Y., Colla., G., 2009. The influence of drip irrigation or subirrigation on zucchini squash grown in closed-loop substrate culture with high and low nutrient solution concentrations. HortScience 44, 306-311. 
Santamaria, P., Campanile, G., Parente, A., Elia, A., 2003. Subirrigation vs drip-irrigation: Effects on yield and quality of soilless grown cherry tomato. J. Hortic. Sci. Biotech. 78, 290-296.

Shannon, M., Grieve. C.,1998. Tolerance of vegetable crops to salinity. Scientia Hort. 78, 5-38.

Valdés, R., Miralles, J., Ochoa, J., Franco, J.A., Sánchez-Blanco, M.J., Bañón, S., 2012. Prueba de sondas para medir conductividad y humedad del sustrato en maceta en condiciones salinas. XI Simposio Hispano-Portugués de Relaciones Hídricas en las Plantas. Libro de actas, 222-225.

Wang, R., Kang, Y., Wan, S., Hu, W., Liu, S., Liu, S., 2011. Salt distribution and the growth of cotton under different drip irrigation regimes in a saline area. Agric. Water Manage. 100, 58-69. 
GENERAL CONCLUSIONS 


\section{General conclusions}

Ficus benjamina and Osteospermun hybrida were moderately tolerant to salinity, whereas Pelargonium x hortorum was moderately sensitive. Gerbera hybrida and Euphorbia pulcherrima were sensitive to salinity. Saline water may be a good alternative to the chemical retardants commonly used in ornamental plant production.

Programmable balances can be used to accurately control irrigation, provided that the substrate used is structurally stable and with sufficient rehydration. This is a particularly important point in saline conditions, which inhibit rehydration in the top part of the substrate.

The use of soil EC and moisture sensors can provide quantitative information to help guide and automate the decision-making process for irrigation. Although collecting data with sensors is relatively easy, data are only useful if the sensors are used correctly and their limitations are understood. Optimizing the value of the collected data requires determining the optimal arrangement of the sensors and ensuring that collected data are as accurate and precise as possible. The proper use of sensors can result in great increases in irrigation efficiency, better salinity control, and improved profitability of ornamental production in greenhouses and nurseries.

Optimizing irrigation decisions requires selecting the best indicator from the collected data, because there are various ways in which sensor data can be used to help make irrigation decisions. Under saline irrigation, the estimation of $\mathrm{EC}_{\mathrm{PW}}$ from sensor outputs should be used because this is the EC "felt" by the plant. Ours findings show that the Hilhorst model is not very accurate due to the influence of salinity, humidity and temperature. Using mean values of $\mathrm{EC}_{\mathrm{PW}}$ calculated between two irrigation events is more recommendable than using a single value to control substrate salinity. The efficient management of substrate salinity depends on a user-defined threshold and the salinity of the water available. Working with a specific value, we recommend using the Hilhorst equation when substrate water content is high. Sensor readings become more scattered as salinity increases, affecting the accuracy and reliability of the estimation of $\mathrm{EC}_{\mathrm{PW}}$. The estimation of pore water EC underestimates real salinity, whereas leachate EC overestimates it, and, both errors become larger as salinity increases.

Bulk EC is more stable than pore water EC because it is measured directly by the sensor. $\mathrm{EC}_{\mathrm{B}}$ is closely related with the real pore water salinity and decreases uniformly as 
the substrate dries out. Despite the strong influence of substrate moisture on the $\mathrm{EC}_{\mathrm{B}}$, our results suggest that the use of this conductivity can be a useful tool to control salinity in the substrate. For best results, measurements should be made in the saturated substrate. Both the post-irrigation $\mathrm{EC}_{\mathrm{B}}$ values and the way in which the $\mathrm{EC}_{\mathrm{B}}$ data decrease (slope) might be helpful for controlling substrate salinity.

We suggest that both salinity and the number of emitters per pot should be considered when developing a water management strategy for container-grown plants. Using more than one emitter per pot is recommended, especially with saline irrigation, because this will attenuate both the reduced aerial growth and leaf necrosis caused by salinity. Increasing the number of emitters increased the homogeneity of salt and root distribution in the substrate, because salts tended to increase around the wet bulb produced by the emitter. 